




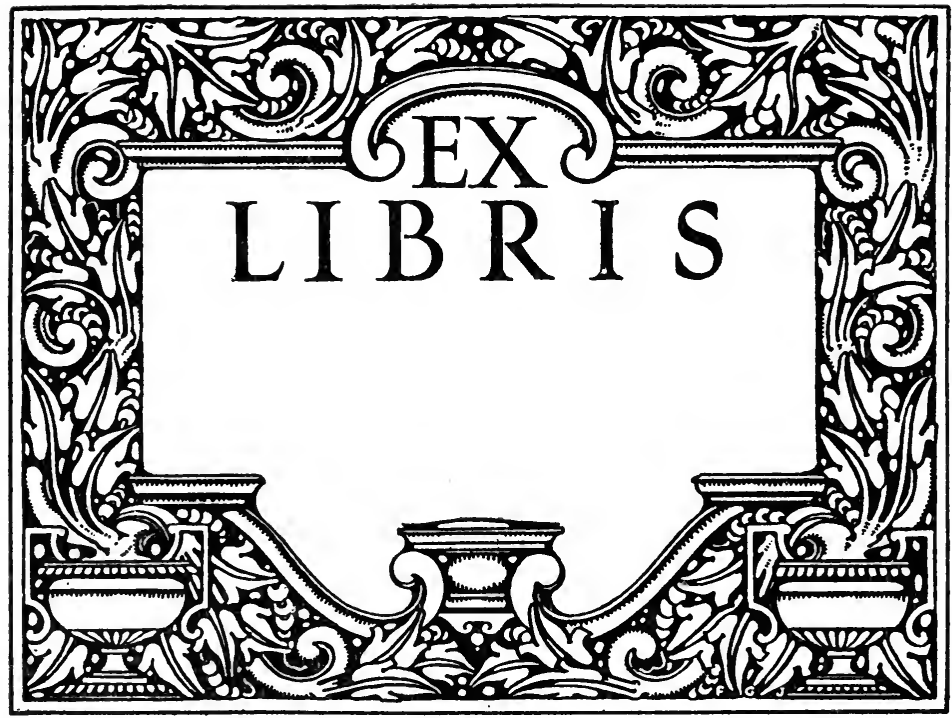




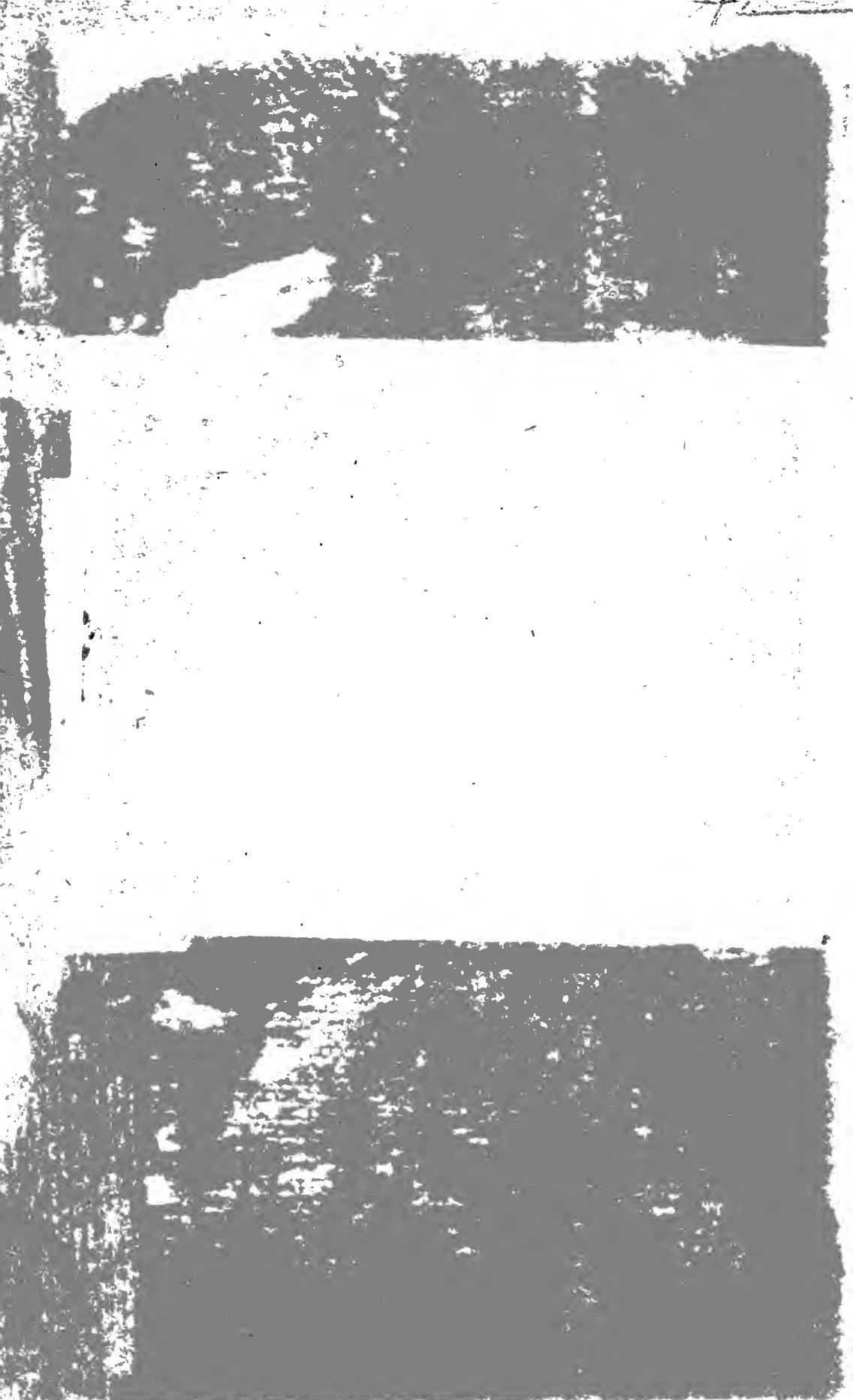


Digitized by the Internet Archive in 2007 with funding from Microsoft Corporation 


\section{JOHN WILLIS CLARK}






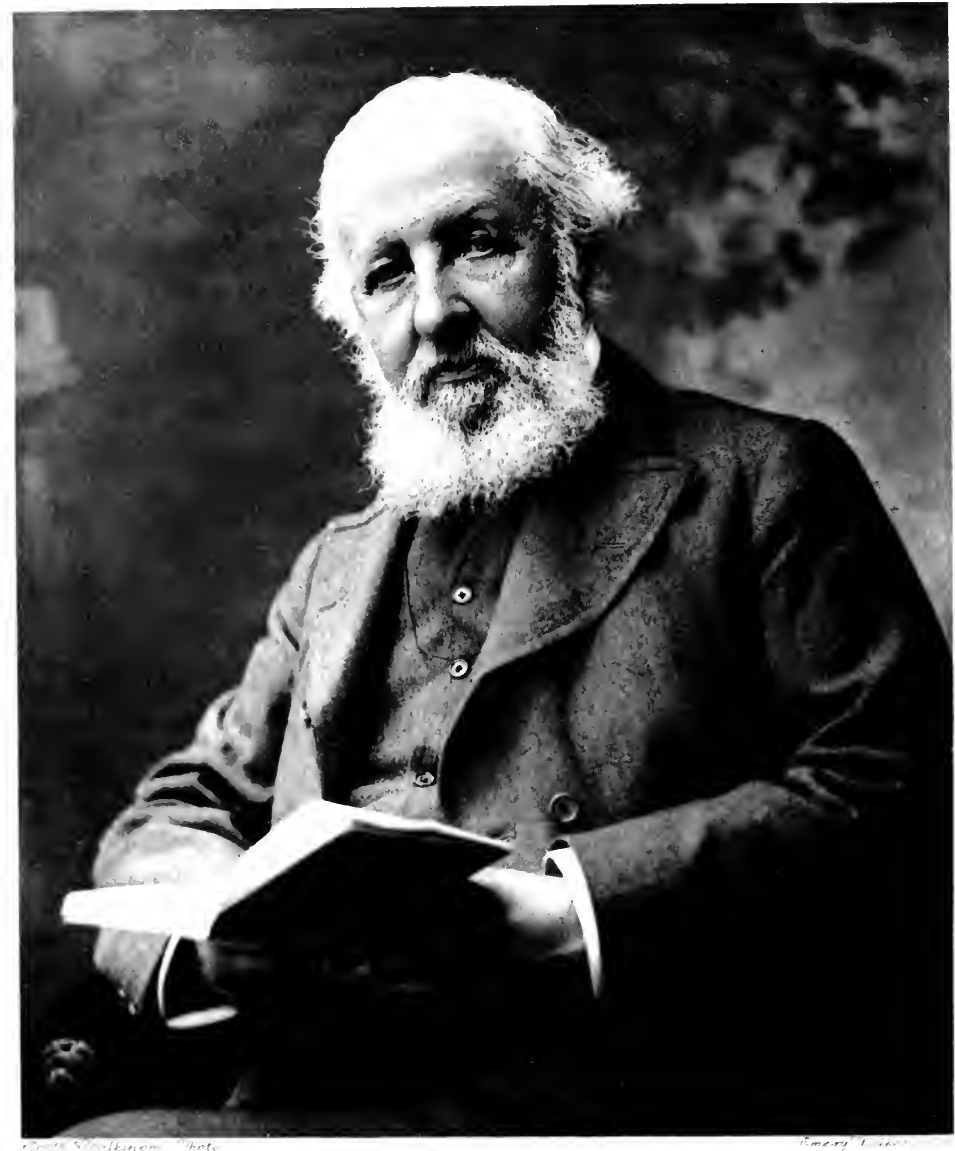

g. W. Clark 


\section{"J."}

\section{A MEMOIR OF}

\section{JOHN WILLIS CLARK}

REGISTRARY OF THE UNIVERSITY OF CAMBRIDGE AND SOMETIME FELLOW OF TRINITY COLLEGE

A. E. S H I P L E Y

MASTER OF CHRIST'S COLLEGE

"But I despair of being able to set forth the man as he was, with all his vigour of talk and action; his fun and his seriousness so strangely blended; his strong affections and his equally strong dislikes; and lastly, but by no means least, so much of his language will offend most sorely the ears of the present generation."-J. W. c. (vide p. 144).

\section{LONDON}

SMITH, ELDER $\circledast$ CO., I5 WATERLOO PLACE. I9I3

[All rights reserved] 

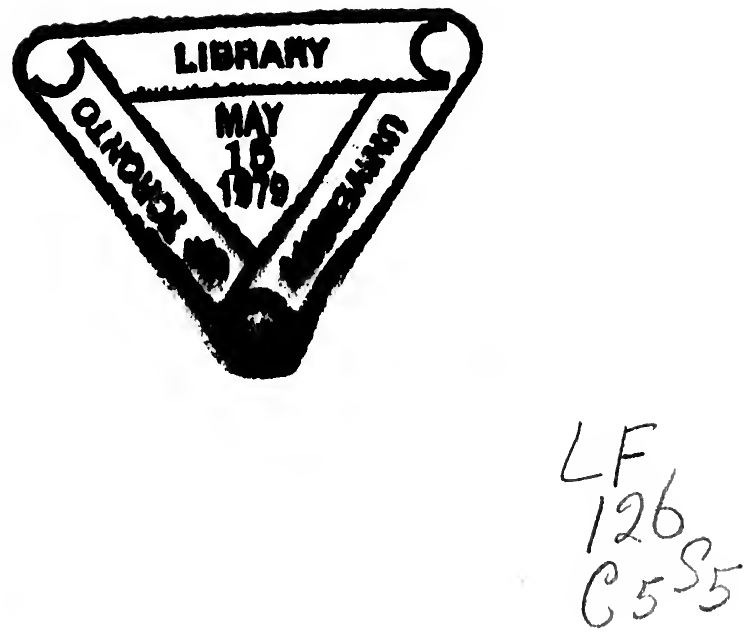

Printed by Ballantyne, Hanson \& Co. At the Ballantyne Press, Edinburgh 


\section{HVNC LIBRVM}

\section{AVGVSTO THEODORO BARTHOLOMEW}

SINE CVIVS AVXILIO NVNQVAM SCRIPTVS ESSET

IN COMMVNIS AMICITIAE MEMORIAM

DEDICAVIT AVCTOR 



\section{PREFACE}

Some may think that this book should have fallen into the category of those that are privately printed, but the late Registrary had many friends-a milky-way of friends, as one of them wrote-and the publishers felt that it would appeal to a circle wider than that which privately printed books usually reach.

I have to thank many of J.'s friends for assistance; without their help this book could never have been put together. I have ventured to dedicate this Memoir to Mr. A. T. Bartholomew, whose aid in gathering together material and reducing it to order has immensely lightened my task. I have put his name on the dedication page, although, in my opinion, it should have been on the title page.

Then I wish especially to thank Professor Henry Jackson, O.M., for his kindness in helping me throughout the last twelve months, by placing at my disposal his knowledge of J.'s earlier years and his unsurpassed and amazingly accurate recollections of the sixties and seventies of the last century.

J.'s elder son, Mr. Edward Mellish Clark, has spared no pains in searching for material for this Memoir, in verifying dates, and in many other ways.

Lord Desart, Sir Harry Wilson, Mr. Lionel Cust, and Mr. A. C. Benson have all of them contributed recollections of J. at diverse periods of his life, and I am grateful to them, and especially grateful to Mr. Walter Pollock, who has written a most informing chapter upon "J.'s Love of the Theatre," a subject I am totally unable even to appreciate. Lady Bonham, the Provost of King's College, and Dr. Guillemard have all given me much assistance and saved me from many a blunder 
by reading the proofs of the book whilst it was passing through the Press. The Vice-Provost of Eton, the Vice-Provost of King's, Mr. W. Austen Leigh, Mr. G. E. Wherry, F.R.C.S., Mr. G. B. Tatham, Mr. R. Bowes, and Mr. Aldis, the Secretary of the University Library, have helped me in many ways. The names of those who have been kind enough to lend me letters are too numerous to mention-I am grateful to them all. Lastly, I have to thank Mr. G. W. Webb of the University Library for the care he has bestowed on the Index, and Mrs. Dew-Smith for giving me leave to include the photograph of J. taken by her husband.

I have added to the Memoir proper, a couple of perhaps rather technical Appendices. The first deals with J. as Superintendent of the Museum of Zoology, the second with his work as Secretary to the Museums and Lecture Rooms Syndicate. This latter Appendix I have continued up till midnight of the 31st of December 1912, when the Syndicate ceased to exist, and this continuation I have written of set. purpose. So far as I know, since 1886, when J. published the Architectural History of the University of Cambridge, no one has put together a record of the vast growth of our Science Schools, a growth which has been made possible only by the generous, and at times most unselfish co-operation, of those whose lives are dedicated to what are sometimes called the older studies.

No Bibliography of J.'s writings has been included, as a very full one has recently appeared in the Catalogue of Books relating to Cambridge bequeathed to the University by John Willis Clark (Cambridge, 1912).

"And here will I make an end, and, if I have done well and as is fitting the story, it is that which I desired: and if slenderly and meanly, it is that which I could attain unto."

\section{A. E. SHIPLEY}

Christ's College, Cambridge, May 1913. 


\section{CONTENTS}

\section{CHAPTER I}

$$
\text { 1833-1844 }
$$

PAGE

J.'s Ancestry, Birth, and Early Years . . . 1

\section{CHAPTER II}

"SIXTY YEARS SINCE"

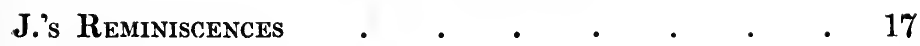

\section{CHAPTER III}

\section{4-1851}

J. AS A Boy.

CHAPTER IV

$$
\text { 1851-1856 }
$$

Foreign Travel and College Life • . . . . $\quad 76$

\section{CHAPTER V

$$
\text { 1856-1873 }
$$

J. AS A Bachelor.

\section{CHAPTER VI}

\section{$1873-1875$}

J.'s Marriage 
CHAPTER VII

$$
\text { 1875-1891 }
$$

PAGE:

J. in his Prime . $\quad . \quad$. $\quad$. $\quad$. $\quad$. 124

\section{CHAPTER VIII}

1891-1910

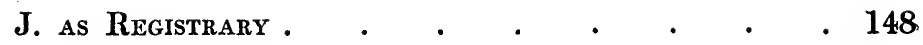

\section{CHAP'IER IX}

J. AS I KNEW Him . $\quad$ • $\quad$. $\quad$. $\quad$. $\quad 210$

CHAPTER $\mathrm{X}$

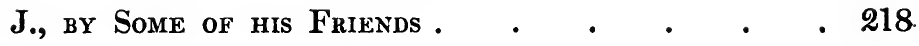

\section{CHAPTER XI}

J.'s Love of the Theatre, by Walter Pollock • • 231

\section{APPENDIX I}

J. as Superintendent of the Museum of Zoology • 257

\section{APPENDIX II}

J. as Secretary to the Museums and Lecture Rooms

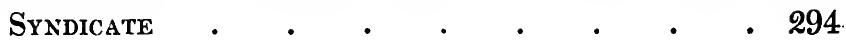

INDEX $\quad \cdot \quad \cdot \quad \cdot \quad \cdot \quad \cdot \quad \cdot \quad \cdot \quad \cdot \quad \cdot 345$ 


\section{ILLUSTRATIONS}

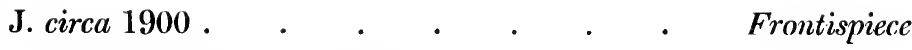

From a photograph by Messrs. ScotT \& WiLkinson.

J. circa 1880 . . . . . . . . T'o face p. 130

From a photograph by A. G. DeW-Suith, M.A.

Plans of the Old Botanic Garden Site in 1873 AND in 1912 . $. \quad . \quad . \quad . \quad$ After p. 343 



\section{JOHN WILLIS CLARK}

\section{CHAP'TER I}

\section{J.'S ANCESTRY, BIRTH, AND EARLY YEARS}

Although by nature $\mathrm{J}^{1}{ }^{1}$ seemed to belong to the south of England, he came of a northern stock. His paternal grandfather, John Clark, M.D. (1744-1805), in his time a wellknown medical philanthropist, was born at Roxburgh and educated at Edinburgh, where at first he studied Divinity. Later, however, he turned his attention to Medicine, and at the age of twenty-four became surgeon's mate to the East India Company. From this service he withdrew in 1775, and having proceeded to the M.D. degree at St. Andrews, he settled down to practise in the neighbourhood of Newcastleupon-Tyne. Here he showed two virtues eminently characteristic of his grandson-kindness and a remarkable power of organisation.

John Clark was the founder of the Newcastle Infirmary, and spent much time and labour in advocating the provision of hospitals for cases of infectious disease. Besides many minor works, his name is remembered by two volumesObservations on the Diseases in Long Voyages to Hot Countries (1773), and Observations on Fevers, \&c. (1780). He married Susanna, daughter of Francis Heath.

1 When J. W. Clark became a Fellow of Trinity, there happened to be in residence some eight or nine other Dons of the same surname, hence from an early date he was called $J$. W. to distinguish him from his rather numerous namesakes. Later, $J$. $W$. was further shortened to $J$. 


\section{J.'s Ancestry and Early Years}

J.'s father, William Clark (1788-1869), was the second son of Dr. John Clark. He was born at Newcastle-uponTyne, and educated at a private school at Welton in Yorkshire. It is recorded that he was prepared for the University by a Fellow of Trinity, a Mr. Popple, and when he was but sixteen years of age he entered that royal and religious foundation. His early training must have been sound, for he was elected a Scholar of Trinity in 180\%, and graduated as seventh Wrangler in 1808. In the same Tripos list Charles James Blomfield, afterwards Bishop of London, appeared as third and Adam Sedgwick as fifth Wrangler. The following year, at the first examination in which they were entitled to compete, both Clark and Blomfield were elected to Fellowships at Trinity, the former having especially impressed the examiners by a brilliant rendering of a passage of Pindar into English verse.

Following in his father's footsteps, William Clark began to study medicine, and, as the phrase used to run, "walked the hospitals" in London and studied under the great Abernethy. In July 1813, Lord Byron, probably introduced by a common friend, Scrope Davies, was corresponding with Clark about a projected journey to the East, but this was abandoned. Four months later, Byron again begged for Clark's company on a journey to "the Zuyder Zee, and, if affairs go on well, Germany and even Italy." This was a critical time in the poet's passionate life, and whether, as Mr. C. Knight Watson writes, it was "from fevers abroad or Miss Milbanke at home, the journey projected in company with Dr. Clark never took place."

During the same year Clark proceeded to the medical qualifications of Medicina Licentiatus sive Practicans in Medicina, but he did not take his M.D. degree until 182\%. In 1814, owing to the death of Sir Busick Harwood, "the Professorship of Anatomy became vacant, and Clark came forward as a candidate. He was not elected. His competitors were Woodhouse and Haviland. Haviland was elected, the num- 


\section{William Clark and Byron}

bers being: Haviland, 150; Clark, 135; Woodhouse, 60. The election is memorable from a circumstance in Byron's life, which is related at once imperfectly and incorrectly by Moore. The version I am now about to give was told us by Dr. Clark himself, and is confirmed in every particular by another eye-witness now living. Byron came down to Cambridge on purpose to vote for Clark. He entered the Senate House for that purpose, leaning on the arm of Dr. Edward Daniel Clarke. ${ }^{1}$ As soon as the undergraduates in the gallery became conscious of his presence, they greeted him with a volley of enthusiastic cheers - a reception for which Byron's avowed antipathy to Cambridge had scarcely prepared him. He left the building, and shortly afterwards Sir John Cam Hobhouse entered it, exclaiming, 'Well! I have seen a sight which I could not have believed possible.' He went on to relate that on going out of the Senate House in quest of Byron, he found him in the precincts of the Schools sobbing like a child, so completely had the poet been overcome by the rapturous reception he had met with." 2

In 1817 Haviland became Regius Professor of Physic, and Clark and Woodhouse again stood for the Professorship of Anatomy, but the latter withdrew, and on the day of the election the former was chosen without opposition. In 1818 and 1819 Dr. Clark travelled on the Continent with Sir Mark M. Sykes, and the coloured wax models of anatomical preparations which he bought for the University at Florence were for long preserved at the Anatomical School.

Clark was Professor of Anatomy, not of Human Anatomy, and he interpreted his duties in the liberal spirit already shown by Sir Busick Harwood. Both seasoned the unappetizing dishes of topographical anatomy with physiology, and flavoured

1 "Stone" Clarke, the traveller, Professor of Mineralogy, 1808; University Librarian, 1817; to distinguish him from "Bone" Clark, J.'s father, and "Tone" Clarke-i.e. John Clarke, afterwards ClarkeWhitfield, Mus.D., Professor of Music, 1821.

${ }^{2}$ C. Knight Watson in Macmillan's Magazine, January 1870. 


\section{$4 \quad$ J.'s Ancestry and Early Years}

them with illustrations drawn from the so-called lower animals. Clark took infinite pains in the preparation of his lectures and demonstrations. He was particularly neat in his dissections, and was a master of the comparatively lost art of injecting veins and arteries. From 1814 until 1832 the Museum of Anatomy was housed in a building opposite the entrance to Queens' College, when it was moved to an incomparably ugly building at the corner of Corn Exchange Street and Downing Street. 'This was the building which, on the night of Monday, 2nd December 1833, was attacked by a mob who considered that Dr. Clark had failed to comply with the provisions of the Anatomy Act in the matter of the body of a pauper received for dissection. The building was ransacked, and considerable damage was done; the Riot Act was read, and many persons were locked up in the Schools for the night. The attack was repulsed largely by the aid of the undergraduates, but I can still see in memory the heavy iron bars which, until the building was demolished (1891), served from the date of that outbreak to protect the doors and windows of the old dissecting room. Throughout all the subsequent inquiries and difficulties, Dr. Clark had the consistent support of Lord Melbourne, then Home Secretary.

Clark spared himself no effort, and his purse no expense, to increase the Museum; and it is, in the main, to him that we owe the foundations of the two magnificent collections, the Museum of Zoology and Comparative Anatomy and the Anatomical Museum. He was in fact-though the fact has been often forgotten-both by his teaching and his collecting, one of the founders of the School of Biology at Cambridge.

During the first half of the nineteenth century the great majority of Fellowships were still restricted to those in Holy Orders. Clark had applied in 1817 for one of the two lay Fellowships at 'Irinity, but had failed to obtain it. $\mathrm{He}$ took orders in 1818, and successively held the small livings of Arrington in Cambridgeshire; Wymeswold in Leicestershire; and the valuable rectory of Guiseley, near Leeds (1826). The 


\section{William Clark}

latter preferment he held until 1859. Although, after the manner of his time, Dr. Clark was in the main non-resident, spending but a quarter of the year in his incumbency, yet he was in advance of his age in the care he took in helping forward the interests of his successive parishes. He took especial pains in the selection of his curates, and at Guiseley restored the church and the rectory, built the parish schools, and in and out of season showed his constant care for one and all of his parishioners. I think it characteristic of the man that when opinion changed as to non-resident parsons (a change not seldom occurs in the popular mind without those most nearly affected being aware of it), and when the importance of residence for a parish clergyman was pointed out to him in 1859 , he immediately resigned the living.

The Natural Sciences Tripos was established in 1848, and the first examination was held in 1851. Dr. Liveing, until lately Professor of Chemistry, was at the head of Class I, and the late Dr. Hort, successively Hulsean and Lady Margaret Professor of Divinity, was second. Dr. Clark took occasion at the establishment of the Tripos to delegate the teaching of Human Anatomy to Dr. (afterwards Sir George Murray) Humphry, and thenceforth he devoted himself to the teaching of the larger subjects of Zoology and Comparative Anatomy.

For many years, and especially in 1852, before the University Commission of that date, Dr. Clark had pressed for the appointment of a Professor of Zoology. When eventually, in 1866, this Chair was established, and most amply filled by the appointment of Alfred Newton, he, thinking it advisable that his own Chair of Anatomy should receive at the same time a new occupant, resigned. The vacant Professorship was wisely and justly given to Dr. G. M. Humphry.

Although Dr. Clark was, as I have said, a founder of our School of Biology, he published but little, and it must have been his renown as a teacher that led the Royal Society in 1836 to elect him a Fellow. His few papers show accuracy of observation, and one of them at least a curious prevision of 


\section{J.'s Ancestry and Early Years}

certain views on embryology which have but lately come again to the fore. He issued, at the age of sixty-eight, his translation of Van der Hoeven's Hand-book of Zoology, in two volumes (1856-58). This is a work not only of erudition but of bulk; further, its translator had to learn Dutch before he could put it into English-a remarkable performance for a man nearing seventy.

In a letter addressed to one of his god-daughters, 20th March 1864, Professor Sedgwick, writing from Cambridge, says: "Dr. Clark is still here, but he has become feeble, and is very seldom seen. Last year he had a stroke of paralysis, from which, however, he is wonderfully recovered, and his mind is quite entire and bright." He aged rapidly, however, and was for a time a little odd. Mrs. Clark nursed him with the greatest care, and for three years before his death did not leave Cambridge for a single day. He died 15th September 1869.

Professor and Mrs. Clark were both very hospitably inclined. They gave numerous and rather lavish dinner parties, where the Professor was the life and soul of the entertainment, but he was curiously averse from his son enjoying the companionship of those of his own age. Consequently, J. was, to use his own words, a "milksop," and when he went to Eton derived comparatively little advantage from the school, and as a schoolboy never really liked it. I have had the privilege of talking to a few-now a very few-of those who knew Dr. William Clark. A very old friend of mine said to me the other day, "I'm so old that my friends have ceased dying," and there are not now many left who knew William Clark. But from what they have told me, and from what I can gather from his portrait and bust, he was a man something of this mould: rather stately, dignified, of a fine presence, very much the gentleman-muy caballero as they say in Spainvery courteous, very simple, very modest, as our grandfathers were, perhaps a little distant, a little reserved; a man who would from his training and his surroundings have been somewhat shocked at the free and easy manners of to-day; not at 


\section{Francis Willis}

all opposed to change-eager indeed to effect change if change were in the right direction; very anxious that the teaching and the organisation of the University should be efficient; a man with, up to his lights, a very strong sense of duty. I feel sure he wore a beautiful white cambric stock, wound again and again round a high collar and tied behind. One of my earliest recollections, as a child of five, is of watching the winding of such a fabric around and around my grandfather's neck. The ceremony was, at that remote date, to me as impressive as a religious service.

Here I must cease as to what I can guess of William Clark's character, but, in telling me about him, the few who knew him have dwelt always on his amazing kindness, his geniality, his smile which "was sunshine," when once one had pierced a certain stiffness of manner. One who knew him well tells us that "those who knew him longest loved him most." At any rate he gave us $\mathbf{J}$.

On his mother's side J. was descended from John Willis, one of the vicars of Lincoln Cathedral, who married Genevra, daughter of James Darling, of Oxford. Their third son, Francis Willis (1718-1807), was educated at Oxford, and eventually became Fellow and Vice-Principal of Brasenose College. He took Holy Orders, but Francis Willis was always more of a doctor than a divine, and he enthusiastically studied medicine. In the year 1749 he married Mary, daughter of the Rev. John Curtois, and shortly afterwards established himself at Dunston in Lincolnshire, his wife's country. Here he is said to have practised medicine without being duly "qualified," but in 1759 his University conferred on him the degrees of M.B. and M.D. Still, it seems that he had broken the rules of medical etiquette, and when, at the end of 1788 , he was called in to treat George III during his second attack ${ }^{1}$ of madness, he encountered great opposition from the regular physicians. Nevertheless, taking an optimistic view of the

1 There had been a previous attack in 1765, when His Majesty was twenty-seven years old. 


\section{J.'s Ancestry and Early Years}

case, and insisting that the King should be treated more gently and allowed greater freedom, he soon became a great favourite at Court. Hannah More's description of him as "the very image of simplicity, quite a good, plain, old-fashioned country parson," sets him before us.

"He was much patronised by the higher classes, and for fifty-eight years he had never less than thirty patients under his care. He was at this time (1788) seventy years old, but 'seemed to be exempt from all the infirmities of old age, and his countenance, which was very interesting, blended intelligence with an expression of placid self-possession.' 1 Miss Burney describes him as ' $\mathrm{a}$ man of ten thousand; open, honest, dauntless, light-hearted, innocent, and highminded.' He joined the corps of Royal Physicians on 6th December 1788, and took up his quarters in the Palace. In the consultation which settled their respective functions, Willis was to have charge of all the domestic and strictly moral management-in accordance, however, with such general views as had been agreed upon. The medical treatment was arranged in the morning consultation, and it was understood that Willis was to take no decisive measure, either medical or moral, not previously discussed and permitted. . . . Willis was soon joined by his son John, whose particular function seems not to have been very definitely settled." 2

The political importance of the King's illness was great. Whilst the Whigs wished the Regent-the Prince of Wales - to exercise the prerogatives of a reigning monarch, the existing Ministry sought to limit and restrict his powers. Both Houses appointed Committees to examine the doctors from time to time as to the progress of the malady.

"Willis, who always professed to be quite sure of the King's recovery, and was high in the estimation of the Tory party, inspired the administration with confidence

1 Wraxall's Posthumous Memoirs, p. 447.

${ }^{2}$ The Insanity of King George III., by Dr. Ray, Utica, N.Y., U.S.A. reprinted from the American Journal of Insanity, 1855. 


\section{Francis Willis and George III}

in the policy they had adopted. Every occurrence at Kew was whispered about in political circles, before it was many hours old-coloured and exaggerated, of course, by the prevalent hopes and fears. The names of Warren and Willis became as familiar as household words, and even served as rallying points for the two great parties that divided the country. In less than a month from the first examination, both parties were equally ready for another, and equally confident of deriving political capital from the result."

Complaints were made that Willis allowed the King to read King Lear-a play the Doctor confessed he was unacquainted with - and to shave himself with an ordinary razor.

"There is a traditionary anecdote connected with this razor scene, strongly illustrative, if true, of Willis's character. Burke asked him, it is said, what he would have done, if the King had suddenly become violent while these instruments were in his hand. Having placed the candles between them, he replied, 'There, sir, by the EYE! I should have looked at him thus, sir-thus!' Whereupon Burke instantaneously averted his head and made no reply.

"Among the gossip of the day was a similar story respecting the effect of Willis's tone on Sheridan when about to examine him. 'Pray, sir, before you begin,' said Willis, 'be so good as to snuff the candles, that we may see clear, for I always like to see the face of the man I am speaking to.' Sheridan was so confounded at this speech of the basilisk Doctor, that he could not get on in his examination, and for once in his life he was posed.

"In the practical knowledge of insanity, and the management of the insane, Willis was unquestionably in advance of his associates; but, following the bent of his dictatorial habits, he often spoke without measuring his words, and often overstepped the limits of professional etiquette. ${ }^{1}$ Hence he suffered under the severe handling of the Committee, to ${ }^{1} \mathrm{~J}$. owed something to his great-grandfather. 


\section{J.'s Ancestry and Early Years}

whom he presented a good many vulnerable points of attack.

"Willis was rewarded by Parliament with a pension of $\mathfrak{L} 1500$ for twenty-one years. He was shortly after employed to treat the Queen of Portugal, but she proved to be incurable. For this service he received £20,000. These fees are without a parallel in the records of the medical profession. Dr. John Willis received for his services $£ 650$ per year during his life."

'The fifth and youngest son of Francis Willis was Robert Darling Willis (1760-1831), J.'s grandfather. Like his father, and like John, his eldest brother, Robert Darling was a doctor; he became Physician-in-ordinary to the King, and attended him during his third attack of madness in 1801. To him and to his two colleagues, Dr. Heberden and Dr. Matthew Baillie, the well-known epigram applies:-

The King employs three Doctors daily-

Willis, Heberden, and Baillie,

All extremely clever men

Baillie, Willis, Heberden,

But doubtful which most sure to kill is

Baillie, Heberden, or Willis.

Robert Darling Willis was the father not only of Mary Willis, afterwards Mrs. William Clark, but of Robert Willis (1800-1875), a man of remarkable energy, extraordinary versatility, and great ingenuity. He had invented successful patents before he entered Caius College, where he was educated, and of which House he became a Fellow. In 1837 Robert Willis succeeded Farish as Jacksonian Professor of Natural and Experimental Philosophy. 'This professorship had, in some mysterious manner, become allotted to the subject of Applied Mechanics, in spite of the specified wishes of the Rev. Richard Jackson in his will of 1775, for while he left posterity a certain discretion in the application of his endowment, it was his "serious request that the said Lecturer will in this Disquisition have an eye more particularly to that opprobrium 


\section{Robert Willis}

medicorum called the gout, both in getting a better history of the disorder itself, and the symptoms preceding, attending, and following it, than is extant at present: also of the best method of procrastinating the fits from coming by the use of diet and the other non-naturals: and in finding a medicine that may cure it (of which I have no doubt from the goodness of God that a discovery may be made)."

Robert Willis may almost be said to have started a new era in combining the study of practical architecture with historical and antiquarian research. His skill as a mechanician made him a master of structure, and his amazing acquisitiveness enabled him to achieve a thorough knowledge of mediæval handwritings and the other obscurities of early MSS. His Architectural History of the Conventual Buildings of the Monastery of Christ Church, Canterbury (1869), was the last and the greatest of his many published works, for he left unfinished the Architectural History of the University and Colleges of Cambridge. The piety of his nephew finished this monumental work (1886); and when I first knew J. its four volumes were drawing to completion. He always alluded to it in an affectionate manner as either his "Immortal Pub.," or "Magnum Opus," or "M.O." for short.

J.'s mother kept a diary. Not at all the sort of thing in which social small talk and the expression of the emotions were recorded. Each volume of the diary was of pocket size, and no entry overlaps its allotted space. This diary has been invaluable as a register of dates, but not very helpful in recalling those things that "slope to the sunny side of life." As was the custom of the time, Mrs. Clark's brother Robert, the Fellow of Gonville and Caius, was ordained Deacon and Priest in 1827, and apparently in the earlier half of the year, for, on the 30th of July 1827, Mrs. Clark enters in her diary, "Married by Robert Willis to Rev. William Clark, M.D., Professor of Anatomy in the University of Cambridge." No more and no less. 


\section{2 .'s Ancestry and Early Years}

I only knew Mrs. Clark when she was well advanced in years, and she struck me-a rather shy undergraduate-as a somewhat terrifying but really kind old lady, stately, accustomed to have her own way, and very formidable if she did not get it. I can't quite remember now how it was that in the early eighties I fell into the habit of going to Scroope House three or four times a term to play backgammon with her. I was then, and am now, simply hopeless at every kind of game. I could rattle the dice and move the draughts in a vague way, but never could I remember how to set the board. My plan was to watch my opponent place piece after piece in the allotted places, and then to set my own in corresponding positions, but one day my ignorance was detected, and I felt how low I had fallen in my opponent's opinion. Still she liked her game, even with a duffer, and I was suffered to go on playing.

Old Mrs. Clark had a certain look of motherhood in her, and without being precisely handsome or beautiful, when you were in the same room with her, you felt you were with a "presence." She belonged to a generation when the Heads of Houses and the Professors lived on Olympian heights, and talked and dined in corresponding altitudes. I think she must have been a little bit like Miss Betsy Trotwood, blended with the better qualities of Carlyle's mother, and perhaps the worst of Mrs. Proudie.

The entries in her diary have all the economy and directness of the meteorologist's weather reports. On the 26th of July 1832, she records "Robert married"; we are not even told to whom, but the Dictionary of National Biography tells us it was to Mary Anne, daughter of Charles Humfrey, of Cambridge. Mrs. Clark had a strong liking for travel, and a real appreciation for art and for architecture, and above all for the theatre. She possessed in a marked degree a sense of form, and was a very accomplished modeller. Not only did she effect wonders in imitating flowers and fruits in thin films of wax -an almost lost and certainly discredited art-and in moulded leather, but she made many anatomical and embryological models 


\section{F.'s Birth and Infancy}

which were of real help to her husband's pupils. She was a lady of strong views, and she expressed them. I have a fancy she was not an easy mistress, at least with the under-servants, and I feel convinced that she allowed no wasteful expenditure in the hospitable house she looked after so well. I know she could "blaze out," and although I was not born at the time, I am still thankful that I was not present when, on 1st November 1853, she "called on Mrs. H— to forbid her the house."

I do not know where the Clarks lived when first they married. 'There is an entry in Mrs. Clark's diary on the 2nd of November 1829, "Slept in Trumpington Street." This looks as if they had just moved in, or maybe they had returned that day from the Rectory at Guiseley. The house they "slept in" is that now occupied by Dr. Roderick, and numbered 17. Here, in what is at present the drawingroom, J. was born on the 24th June 1833 . On the 3rd of September we read, "John Willis christened at 2 at Bene't Church," No. 17 Trumpington Street being in that parish. On the 10th of October "Vaccinated baby"; a week later "Shortened little John"; on the 23rd of November "Began to feed little John with tops and bottoms." "Tops and bottoms!" I wonder if they use them now; the very name carries me back to a nursery of forty-five years ago. On the 17th of April 1834, "Little John cut his first tooth "; a week later "Little John had four teeth," and on the following day "Cut the fifth." On the 17th of July, when he was barely on the shady side of twelve months, "Little John ran alone." The whole career strikes me as very rapid, but J. was never one who wasted time. However, I cannot pretend to be an expert on such matters.

At the beginning of the October Term, 1835, the Clarks moved into the pleasant Georgian house, now the home of the Girls' Friendly Society, lying just south of the Roman Catholic Church at Hyde Park Corner. This was Wanstead House, so called from having been built and furnished with much of the material (especially the beautiful carved fireplaces and 


\section{4 .'s Ancestry and Early Years}

mantels) from the original Wanstead House in Essex. It had been occupied by the Rev. 'Temple Chevallier (17941873), a well-known mathematician and astronomer, who was leaving Cambridge to become Professor of Mathematics at Durham University. They did not, however, remain long here. Towards the end of 1837, we find Mrs. Clark busy in copying the "plans of the ground upon which our house is to be built," and "the plan of our house from Mr. Walters," and on the 20th of November, "Dr. Clark laid the first brick of Scroope House," a house destined for three-quarters of a century to be the centre of a liberal and refined hospitality, and to be a second home to generation after generation of Cambridge undergraduates.

'They first slept in Scroope House on the 6th of October 1838. " Whilst it was being built, the education of "Little John," who now becomes "Johnny" in his mother's diary, was by no means neglected. He had seen in the house in Hills Road "the gas-lamps lighted" for the first time-gas was evidently a novelty in $1836 ;^{2}$ he had fallen out of his crib; before he was four he had attended the service at King's College Chapel, and had visited the Anatomical School, the Botanic Garden, Christ's College Lodge, and the swans at St. John's.

J. had more than one brother. Only one of them, however, lived for more than a few hours, and he died an infant at Cambridge when his parents were absent at Guiseley. Hence J.'s life as a boy was that of an only son; hence also he lived more with his parents than would have been the case had the nursery been crowded. He once told me of the tedium he endured after the mid-afternoon dinner, when he and his mother were expected to sit still for a couple of hours or more whilst Dr. Clark read the Times, or "closing his eyes, indulged in deep thought." Mrs. Clark could noiselessly knit or quietly

1 Professor Haviland succeeded them at 17 Trumpington Street.

2 The records of the Cambridge Gas Company show that gas was fitted for Dr. William Clark on the Hills Road in February 1836. 


\section{Z.'s Early Years}

model, but think of J. at eight or ten having to sit " melancholy as a gib cat," and at an age when dinner makes you want to get up and jump about!

It would be idle to dwell longer on the concise brevity of Mrs. Clark's entries in the diary about "Johnny." He had the usual vicissitudes of small boys: his ailments not unattended by leeches, his fall off his pony, his less of his first tooth, his first lesson in Latin-he had two first lessons in Latin-his first lesson in dancing, which took place in the Lodge of Corpus Christi College, and in fencing-all are duly recorded.

In 1842, when he was nine years old, they all went abroad, and from the middle of July until the middle of September toured through Belgium, the Rhine Provinces, and the northeast corner of France. Two years later they were again in Boulogne. J. attended school for a short time there, but in later life could recall nothing about it.

One of the few who remember J. at this period of his life recalls the fact that he was " a boy with long yellow hair over his shoulders. He was much spoiled by his parents, especially by his mother, and was therefore a little of a nuisance. $\mathrm{He}$ used to come down into the dining-room after dinner, and got into the habit of slapping the ladies' shoulders as he passed behind their chairs. One day he was doing so, and when he came past my chair I boxed his ears, telling him to behave himself. This naturally produced a scene and tears from the mother and child : fortunately for me, the Professor interfered and said I had done right. Ever after the boy treated me with considerable respect."

An entry in Mrs. Clark's diary on the 2nd of March 1846, "Went with Johnny to see Genl. Tom Thumb," recalls one of the most celebrated Town and Gown rows of the nineteenth century. This has been described by J. in Cambridge: Brief Historical and Descriptive Notes (1881).

"In March 1846, an American dwarf called General Tom Thumb was exhibited in Cambridge. He was shown in the morning for half-a-crown, and in the evening for one 


\section{I6 J.'s Ancestry and Early Years}

shilling, the latter exhibition being intended for the townspeople, the former for members of the University, who are popularly believed in Cambridge to be the possessors of boundless wealth. But even as that ingenious contriver of a hen-house, who made a large door for the hens and a small door for the chickens, found that all the birds preferred to use the larger one, so did the promoter of this exhibition behold his room empty in the morning, and crowded in the evening, not with shopkeepers, but with undergraduates. What great events from little causes spring! The burghers, indignant at what they regarded as an invasion of their rights, hustled the undergraduates, the undergraduates hustled the burghers; the fight, from a skirmish on the first night, became a battle on the second, and on the third a deliberately organised trial of strength between the opposing forces. It ended in a complete defeat of the undergraduates; indeed, we have heard that they turned tail and run away, but this we regard as a base calumny. 'The weight of the other side, aided by the truncheons of the police, probably decided the fortunes of the day; anyhow, the gownsmen fled through Rose Crescent into Trinity Street, hotly pursued. When they reached Trinity College, the great gate was opened to admit them-by that time a disordered and grievously wounded mass of men belonging to various colleges-and there they passed the night, uncomfortable but safe." 


\section{CHAP'TER II}

\section{J.'S REMINISCENCES}

When J. was a boy-a very observant boy with a very retentive memory-society at the University consisted of two classes; the Heads, and the other members of the University. A few privileged professors were allowed occasionally to mingle with the seventeen oligarchs who in those times governed it, but their position is truly represented by the phrase "allowed to come in to dessert." The undergraduate was as nobody. "You ought to remember, sir, the immeasurable distance that exists between an undergraduate and the Master of his College," said Dr. Mansel, Master of Trinity from 1798 to 1820, to some unhappy human being who had ventured to accost him. "All communications to the Master are to be addressed through the College Tutor," another Master of the same college said to a junior member of Trinity who had the temerity to remark that the day was wet when taking shelter from a rain-storm under the same archway with the Head of his House. At the beginning of the nineteenth century the exclusiveness was not so great; Dr. Mansel, quoted above, gave evening parties, but Dr. Mansel had six unmarried daughters. "What do you talk about in your society, is it amusing?" said the wife of a Head to the wife of a Professor in 1819. It must have been a personal experience which J. relates when he records that "the only son of the host was not allowed to dine at his father's own table because, forsooth, the Master of his college was expected there as a guest."

At the time Mrs. William Clark married, there were but few married ladies in the University. She knew but one, Mrs. A - , the wife of the Head of one of the two Colleges nearest to their home. This lady had, I believe, been at the same school 
with J.'s mother. As a young bride Mrs. Clark was naturally in considerable awe of the formidable society into which she was to be introduced, and trusted to Mrs. A— for a friendly welcome. To her dismay Mrs. A- and the wives of the other Heads of Houses completely ignored her. Except for the kindly calls of a few "obscure graduates" she was left severely alone. After weeks of solitude she one day caught sight of Mrs. A- on the other side of Trumpington Street. Mrs. A- was passing her without any sign of recognition, but suddenly halted, looked up and down the street to see if she were observed, and then darting across the road, said: " $\mathrm{My}$ dear, I'm so sorry I can't call upon you; the wives of Heads only call on Heads' wives."

Things, however, began to improve. Mr. Serjeant Frere had been elected in 1812 to the Mastership of Downing, and having spent most of his life in London, he and his musical and charming wife were ignorant or oblivious of the cast-iron restrictions of their position. They, like S. Mansel, gave evening parties. I remember seeing an old diary of Lady Affleck, wife of Dr. Whewell, in which she recorded that the Freres had entertained a company of "Heads" at dinner; "some people came in in the evening, but of course roe went away."

This state of things was, however, passing, and the charm and hospitality of Dr. Clark and his wife speeded its passing. I had at first intended to abstract J.'s Reminiscences, or at least to abridge them, but on re-reading they seem to me so admirable, so full of knowledge of the "days of peace," as J. was fond of calling a past which few can remember, and so well expressed, that I have reprinted them almost at full length. ${ }^{1}$ They begin, it is true, with picturing a Cambridge some years before his birth, but he heard of it at first-hand from his parents, and it would be impossible and inadvisable to attempt to disentangle it from the Cambridge he himself knew and loved. As the late Mr. Pierpont Morgan said, "You cannot unscramble an egg."

1 With the permission of the Proprietors of the Cambridge Review. 


\section{Cambridge in 1820}

Let me explain, before I write a line of what will probably be called "My Reminiscences," that in the space allotted to me, and the time at my disposal, I cannot do more than make a few notes about a state of things which has vanished as completely as the Ruffs and Reeves from our pastures, and the Big Copper butterflies from the neighbourhood of the equally extinct Whittlesea Mere.

And now, before I call up from the shades those who are to play their parts in my drama-or shall I say my comedy?let me set the scene, let me try to point out how different the town of Cambridge, in, let us say, 1820, was from the same place to-day. Imagine a freshman arriving in a coach or a post-chaise by the London Road. The road itself has been but little altered. The houses did not begin till "Spital End"-the name given to the corner by Downing Terrace, from the Almshouses called Hospital of St. Anthony and St. Eligius, which then stood there. Thence, on the right, were houses without interruption, as at present; but on the left after passing Love Lane, now Coe Fen Lane, was an open space called Gravel Pit Close, succeeded by a house standing in a field so large that it might almost be called a park. The house, Grove Lodge, is there still, unaltered; but the park with its trees, which made a pleasant shade along the road opposite to Addenbrooke's Hospital, then a small building in a large garden, have long since disappeared. The last elm went down in a violent gale in October 1881. Next, where the Fitzwilliam Museum now stands, was a row of mean houses and shops, the destruction of which is one of my earliest recollections. Peterhouse is not much altered, except that in those days it was bounded next to the street by a high wall, which secured privacy at the cost of light and air. The watercourse ran down the street as at present, but in a single stream in the middle of the roadway, thereby causing much interruption 
to traffic. Between the corners of Mill Lane and Pembroke Street-where in old days there was a bridge over the King's Ditch, and a gate called Trumpington Gate, the town proper was entered. From this point the houses became loftier and more tightly packed, and the street far narrower, the usual contrast in fact between a suburb and a town. Where the Pitt Press now stands, a famous hostelry, "The Cardinal's Cap," invited the attention of travellers. From this inn, as far as Great St. Mary's Church, the street was bounded on both sides by nothing better than shops and houses, with the exception of St. Botolph's Church on the right, and St. Catharine's Hall, as it was then called, on the left. This college had wisely replaced worthy Thomas Hobson's stable-yard by a grove of elms; but Corpus Christi College did not get its new quadrangle until 1825, and King's College did not throw open its court until the same year. In front of that college the street became so narrow that it used to be said that an able-bodied man could spit across it. Opposite to Great St. Mary's Church, an open space was reached at last, called, as now, Senate House Hill. But, if a traveller turned aside at this point towards the market-place, he would have found the east-end of the church encumbered with houses and shops, and the chancel-wall begrimed with the smoke of a baker's oven, and the market-place itself not much wider than an ordinary street. It was a quaintly picturesque spot, that ancient market, its shape like a capital letter L; with its seventeenth century conduit, forerunner of the waterworks of our own day, tumble-down stalls, and shops, the front of which sometimes did duty as a counter to display the vendor's wares. A beneficent fire in 1849 made short work of the west side, and then the modern spirit got his claws into the rest, and away went the Picturesque in favour of the Convenient and the Sanitary! As might be expected, the streets in the neighbourhood were equally curious-especially the Petty Cury, with its two glorious old inns, "The Falcon" (sacred to the memory of Mr. Pepys), part of which still survives, and "The 


\section{Cambridge in 1820}

Wrestlers," the front of which, with its great oriels and lofty gables, it would have been hard to beat. But in all directions the same features would be noticed-narrow, crowded streets, with fine buildings here and there, but half shut out from view. Trinity Street, from Senate House Hill to Trinity College, may serve as a type of many streets; Bridge Street could perhaps show then, as it can now, more old houses, and was noisier and more crowded with carts, drays, waggons, packhorses from the country and the river. Trinity College was approached along a narrow thoroughfare bounded by high walls; St. John's College was half hidden behind another wall, while the tower of All Saints' Church projected far into the roadway. One pleasant feature of old Cambridge was the number of trees. I have already spoken of the elms opposite Catharine Hall. There was another and, to judge from old prints, finer grove where the screen of King's College now stands; and Provost Okes told me that members of the college were occasionally allowed to shoot the rooks that built therein; at St. John's there was some splendid ivy, boiling over the old red brick wall into the street; and at Sidney-Sussex College was a row of poplars just inside the wall on the side of the court next the street. I may have to recur to other features of the quaint old place that I remember so well; for the present let me insist on one point most emphatically-the Cambridge of 1820 was to all intents and purposes the mediæval town into which the University had intruded itself in the thirteenth century. The population in 1821 did not exceed 14,142.

Let us suppose that our freshman gets rooms in Trinity College. He would find life somewhat rough. It was not the fashion in those days to make a set of rooms pretty, and a "scheme of colour" was not so much as thought of. A few indispensable articles of furniture were bought, and that was all. Of light and warmth the supply was scanty. The courts were lit with oil lamps, and the staircases with tallow candles. The Chapel was not warmed in any way, and the 
Hall had only the central brazier. I have heard Professor Sedgwick describe how in his early days (he came up in 1804) the floor of the Hall used to be covered with sawdust at the beginning of winter in order to produce a certain amount of warmth, and that the said sawdust was raked over from time to time, as the uppermost stratum got dirty, so as to lay a cleaner stratum uppermost. In private rooms fires could of course be lighted at the pleasure of the occupant, but he was to a certain extent at the mercy of the weather, and in severe winters, when the Cam was frozen over, and barges could not get up from Lynn to Cambridge, the supply of fuel has been known to run out, and chairs, gun-cases, and other articles of furniture were used until they also came to an end-and then the shivering owner of the rooms had to sit in his greatcoat and pray for a thaw. 'The Senate House, in which all the University examinations were then held, was not warmed, and, as they were held in January, many were the devices resorted to to keep out the cold. I have heard of men being so cold that they could not think, and those who cared for their personal comfort wore two or three sets of underclothing, two coats, and the like. In those days, and far later still, the older members of the University seemed to be quite insensible to cold. I can recollect that so late as 1859 the library of Trinity College was not warmed, and the unfortunate under-librarian, who had to sit in it for a certain number of hours in each day, trembled with cold. Dr. Whewell, then Master, could with difficulty be made to see that some remedy ought to be provided, and though he was the most generous of men, quite ready to admit that he had been in the wrong when convinced of his error, I doubt if he ever quite forgave one of the Fellows ${ }^{1}$ who came forward with a plan which showed how the warming might be effected, which plan the Seniors adopted, notwithstanding the Master's opposition.

Water was supplied by the aqueduct first brought into 1 J. himself. 


\section{Town and Gown}

Cambridge by the Franciscans from a spring between here and Madingley, and tapped by King's Hall as it passed their gate. When I came up in 1852 baths were unknown in College rooms. We used foot-tubs, and basins, and so forth. In the following year some enterprising youngster, in advance of his time, brought a bath into College, and insisted on his bedmaker filling it every morning from the fountain in the Great Court. Great was the indignation felt, and expressed, by those venerable ladies; and there might perhaps have been a general strike if a timely concession had not been made by laying on the Water Company's supply to the different staircases.

Our freshman would not have passed many days in Cambridge without discovering that the Town and University were on anything but friendly terms. Nor is this attitude to be wondered at. The University complained, as they had done in the reign of Henry the Third, when a great quarrel arose over the price of lodgings, that the townspeople fleeced them. The townspeople retorted that the University was perpetually treating them with gross injustice in taking up a positiondue to the privileges unwisely granted by several kings-which belonged of right to themselves. Moreover, they were probably aware that they were spoken of collectively by their insolent neighbours as "the snobs." The result was a state of perpetual antagonism, which broke out every now and then, after the manner of a volcano. The eruption usually took the form of a town-and-gown row-what is in these days elegantly termed "a rag"; but it was a much more serious affair when I was young. I may mention here that in those days goods were brought into Cambridge either by waggon or by barge. The latter method of transit introduced the bargee element into the population. The bargees were fine stalwart fellows, who dearly loved a fight, and many of them were skilled in the art of self-defence, then extremely popular. The most proficient soon got to know equally proficient undergraduates, and both parties eagerly welcomed an occasion for a real 
good set-to. It was dull work to meet merely for the sake of a boxing match, but a street disturbance offered an enjoyable diversion; much blood was shed (from the nose), and many heads were broken. Now and then there was a rustication, but not often; and a few days afterwards it all began over again.

Professor Pryme in his Autobiographic Recollections gives an interesting account of what he remembered about the dress worn in his early days. Old gentlemen still wore wigs, and there was a College porter who dusted and powdered them. I never saw a wig worn, but $\mathrm{I}$ have seen Dr. Procter, Master of Catharine Hall, who died in 1849, wear knee-breeches at a dinner party in my father's house; and I have heard my mother say that Professor Pryme, during the Reform Bill agitation, wore nankeen breeches at a dinner party given by himself, with a bunch of blue and yellow ribbons at each knee, a blue coat with brass buttons, and a buff waistcoat. I may mention by the way that Pryme, though a Fellow of Trinity, and a Master of Arts in a University that could not be described at that time as liberal, actually sat as Member for the 'Town of Cambridge in the first reformed parliament, without losing a friend or making an enemy-a feat which shows that Cambridge could, at any rate, appreciate sincerity. I have heard that in 1829 William Makepeace Thackeray wore, when full dressed, a blue coat, cut like a tail-coat, with gold buttons. After 1852, when I became an undergraduate, I remember that the older members of the University used to tie the strings of their gowns; and that clergymen, who were in the majority, swathed their throats in stiffly starched white neck-cloths, while laymen wore coloured scarves tied in a similar fashion, and occasionally a blue coat with brass buttons. Speaking generally, the cut of their clothes recalled the fashions of the eighteenth century, repeated in black, with dark grey for the trousers. Undergraduates did not dress for Hall, as they did in Professor Pryme's day, but they invariably put on a black coat and waistcoat. If they did not they were 


\section{The Fasbions}

liable to receive a message from the Dean, requesting the offender to go back to his rooms and change his coat before eating his dinner. The fashions of the outer world are sure to be reflected at the Universities sooner or later, and when "the Dandies," as they were called, were paramount in London, their style was imitated here. Men who could afford the expense exhibited themselves on King's Parade, between two and four, arrayed in the extravagances of costume with which the illustrations to Dickens have familiarised us. There were to be seen high velvet collars on cut-away coats, stocks and costly shirt-pins, embroidered waistcoats, and peg-top trousers (as I think they were called) kept in shape by straps. A real exquisite, who wished to copy that great exemplar of fashion, Count D'Orsay, discarded upper leather to his boots, and had them finished off with the same stuff as his trousers. When a man went to a ball in the thirties, he had his hair curled by a hairdresser, and, if he were a Fellow of his College, the haircurling probably took place in the Combination Room. In my own time this fashion was no longer observed; but due cultivation of the hair was considered of importance. Whiskers were encouraged, of what was called the mutton cutlet type; but the chin had to be shaved, and no moustache was permitted. The Volunteer Movement of 1859 was responsible for both beard and moustache. I remember a man in my own year, afterwards a Fellow, being told by the Dean to shave off a moustache on which he prided himself not a little. He obeyed, but he expressed his regret in verse, of which I will quote a few lines :-

"Dean! Is thy seat so lofty that its snows

Have gathered to thy heart and settled there !

Can my beard mar the heaven of thy repose?

So great a man, and such a little hair !"

While dealing with this part of my subject let me impress upon my readers that academical dress was much more generally worn in old days than it is at present. I need hardly say that I cannot vouch, by personal recollection, for what was done in 1820 , but all that $I$ have heard in conversation, or read in 
memoirs, leads me to the conclusion that both old and young"dons" and undergraduates alike-generally wore their caps and gowns in the streets. In 1852 and succeding years, such was certainly our practice; I think that we were rather proud of the mark which differentiated us from the "snobs"; and on Sunday not even the excuse of a country walk was sufficient to soften the hard heart of the proctors. A Head of a College on his way to the University Sermon has been known to stop an undergraduate walking in the opposite direction, and make him precede him to Great St. Mary's. But, as I said above, undergraduates wore their caps and gowns as a matter of course. I can remember a distinguished mathematician in my own year, afterwards an equally distinguished judge, lamenting that his pupils would always come to his rooms in cap and gown and be so distant as to refuse to talk. When a reaction against those ancient formalities set in, and Fellows of Colleges began to be seen in the streets clad in an old flannel suit, and wearing a beard and moustache, older members of the University were shocked. Dr. Whewell, on such a man being named in his presence, said, in a tone that spoke volumes: "I have obsarved the parson." (Dr. Whewell's mode of speaking betrayed his North Country origin.)

\section{II}

Since I began to write these recollections a possible objection has occurred to me, namely, that they are drawn to a great extent from a single College. I will try to remedy this defect (if it is a defect) before I have done. Meanwhile, let me say that I do not think other Colleges differed very much from my own. The roughness that I have described belonged to the age, not to any particular House.

Let me now try to describe an undergraduate day such as I remember it "sixty years since" (if I may speak in round numbers); but, before I begin, let me remind my readers that the undergraduate world of those times was a small one ac- 
cording to our modern ideas. I see that in 1852 there were only 616 degrees taken in the University, as against 1466 in 1908. Further, we were pleased to regard ourselves as divided into two sets-reading men and fast men, or, as they were sometimes called, row-ing men, that is to say, men who frequently got into rows. We did not accept any delicate shades of graduation. If a man did not read (in our acceptation of the term) he was ticketed off and cast aside. He might be cultured and refined, acquainted with two or three modern languages, a traveller in foreign parts, a musician, an artist -if he did not "read," he was viewed with some suspicion, and kept at a certain distance. Gradually this ridiculous prejudice died away, but when I first entered the University it was in full vigour. Now for our day.

The reading man got up at 6.30 , and managed to get to Chapel at 7. It was not the correct thing, in his set, to go to Chapel in the evening; and the deans of those days-though they could be severe, very severe, on occasions-accepted five or even four morning chapels in the week, provided that there was absolute regularity about morning and evening service on Sunday. Whewell has been heard to divide attendants at Chapel into the "orthrodox and the hesperodox." There had been a great misunderstanding between the undergraduates and the authorities in 1838 about attendance at Chapel_of which more anon-but before my day things had settled down, and terms of peace had been arrived at. Chapel over, the Fellows usually took a stroll in the College grounds, but the undergraduates-except the crews of the boats, who ran as far as the Observatory and back-went straight to their rooms, some to finish their toilet, which was apt to be a trifle hasty in the gloom of a winter's morning, some to breakfast as quickly as they could and get ready for lecture. For freshmen, lectures began at nine, and continued till eleven; for men of other years they were at various times during the morning, but I do not recollect that any were given later than one o'clock. After lectures there was private work, or 


\section{8}

\section{F.'s Reminiscences}

a visit to a private tutor, and then came lunch. This hardly deserved the name of a meal, and was soon despatched. It consisted as a general rule of bread and butter with a slice of cheese, or a cut at a cold pie which had already appeared on the breakfast table. The luxurious and the wealthy allowed themselves something hot from the kitchen, occasionally, but not as a regular habit. Then came exercise. The regular exercise for the reading man was a walk from two o'clock to four o'clock-usually round "the Grantchester grind" as it was called. He started along the 'Trumpington Road, made a round by Grantchester mill and the church, and over the fields home. It is a matter of tradition that men have been seen doing this in their caps and gowns, but I cannot bear the testimony of an eye-witness to this, except of course on Sunday. Those who could afford it rode, and perhaps many who could not; for large parties used to start together by the Trumpington Road, some galloping along the road itself, others preferring the fields, where they could "lark" over the fences. A few kept horses of their own, but the majority depended on the tender mercies of Messrs. Jordan or Messrs. Death. The horses were not thorough-breds, but they did their duty in one way very thoroughly, they provided an infinite quantity of amusement and healthy exercise. In the early days of the century, before the Inclosure Acts, some of the finest riding ground in England lay just outside Cambridge. I have heard my father say that when he and his friends started for a gallop, they avoided the ground between Lensfield Road and Bateman Street because it was marshy, and kept to the Hills Road for a short distance; then they turned off to the left, and made for the Gogmagogs. When they had once reached the rising ground, they could gallop for any number of miles over the short velvety turf which always flourishes on chalk.

In summer there was cricket and boating for those who cared about such things, but neither game inspired (except in its ardent votaries) the absorbing interest with which we 


\section{Dinner in Hall}

are familiar to-day; and in winter, football (shall I say happily?) was unknown. ${ }^{1}$ I remember the first attempt to get up University Sports. I wish I could recollect the year. It was a ludicrous failure, received with shouts of laughter. Little did those who laughed imagine that they were standing beside the cradle of an infant whose victorious career would one day emulate that of Napoleon.

But I am wandering away, as is the manner of garrulous old fogies, and if I don't stop we shall be late for Hall. Dinner was served in Trinity at four precisely. A few years before, the hour had been three. The whole College dined, or was supposed to dine, together, though of course a man could get marked, as at present, if he chose. The dinners were not subdivided, and I need not enlarge on the crowding which occasionally took place. Later on, somewhere about 1864, a small dining club was started called the Anti-Dining-inHall-on-Sunday-because-of-the-Squash-and sometimes known by the first letters only of those words, which letters were supposed to form a word of their own, but what it was I never understood, though I often enjoyed the hospitality of the Institution, and very pleasant little dinners they were, given at, I think, the Lion Hotel. Well-to go back to, let us say, 1852. The undergraduates' dinner consisted of joints of beef and mutton set on the tables at short intervals, with dishes of vegetables between the dishes of meat. In my time china dishes were used, but shortly before that date they had been of pewter. The meat was excellent, and well cooked, but there were no carvers, and men helped themselves. When Mr. Smith had cut off a plateful, he pushed the joint to his neighbour. Happy he who got the first cut, and most unhappy he who came in late, and found little left but bones with a few rags of meat clinging to them, and cold gravy. Those who were particular about their dinner used to be ready when the

1 Since writing the above I find an edict of the Vice-Chancellor, dated 29th October 1632, prescribing the places where students might play football, as though it were then a common game. 
door opened to spring into a place opposite to a promising joint. For those who wanted something more tasty than plain meat there were "sizings" - -soup and pudding and cheesebut it was imprudent to "size" soup, for while you were eating it the joint was vanishing. It was the old fable of the dog and the bone repeated in actual experience. The waiters -it is almost incredible-were bedmakers, who performed their duties in bonnets and little shawls pinned round their shoulders-I suppose to keep out the draughts, which were numerous and strong. The hall was lighted by gas brackets projecting from the walls, so the light was wholly insufficient. Later on a large brass standard appeared in the middle of the hall, which certainly dispelled some of the darkness; but nobody liked it, and the undergraduates nicknamed it, by a strange perversity, "Anti-Christ."

Hall despatched-and it never took long-came the pleasantest part of the day-a quiet chat with two or three intimate friends, or an hour's rest in an arm-chair in one's own rooms, in the full enjoyment of some piece of modern literature. We had our literary and artistic enthusiasms even in those days of peace, when storms of war and politics might be raging outside, but rarely disturbed what somebody called "the magnificent repose" of Cambridge. But to this subject I will recur presently. Ruskin woke us up, and it was delightful to read the "purple patches" of that master of style, and to follow him in his denunciation of most of the artists whom we had been taught to respect. Then there was Alexander Smith and his Life Drama, a poem which we thought the finest in existence (I need hardly add that we had not read much else). Some of us attempted Festus (I wonder if anybody reads these works now), and other productions of what a cold and heartless critic called "The Spasmodic School," and we went on from one adoration to another till all our lights were suddenly extinguished by that audacious writer Mr. T. Percy Jones, ${ }^{1}$ whose Firmilian, or the Student of 


\section{"A Wine"}

Badajoz chased our favourite poet out of court with peals of laughter, and restored us to common sense. Some of us went straight from Hall to the Union and read the newspapers; and of these a small contingent took the events of the day very much to heart, and used eagerly to seize on the unwary, to walk him up and down the court, and predict the immediate ruin of the country.

Occasionally the period which intervened between Hall at four and evening Chapel at six was occupied by a wine-party. That curious ceremony deserves a place in my recollections, for it was, after all, a ceremonious function, which nobodynot even the rowdiest and fastest among us-could have thought amusing, or in fact anything except a sort of occasional sacrifice demanded by society. The entertainment flourished best in lodgings. We will therefore imagine our friend Jones, humbly lodged in two rooms, sitting-room and bedroom, on a second floor in Trinity Street. It occurs to him about the middle of the Michaelmas term that he ought to give "a wine." $\mathrm{He}$ invites his entire acquaintance, not merely his friends, but everybody whom he knows, even distantly. His room measures, we will say, fourteen feet by twelve, but what of that? The great god fashion must be propitiated. Then he orders a dessert-not necessarily a very expensive or lavish affair-and finds out whether he has got enough port or sherry to satisfy his guests. They arrive. The knowing ones come early to get a seat at the table, where there is room for twelve or fourteen, and these only have a chance of getting something to eat and drink. The rest stand and depend for a glass of wine on the charity of the seated. The door of the bedroom is opened, and a few take refuge therein. Presently one of the itinerant bands of music, which used to parade the streets in the hopes of an engagement, rings the bell, and asks if its services are not required. A bargain is quickly struck, and a harper (there was invariably a harp on these occasions), with other makers of noise, establishes himself on the stairs. Then the hubbub roared full cry. The 
music tried to drown the talkers-the talkers tried to drown the music. Conversation there was none, only a noise. Then came smoke. In a short time the atmosphere became dense, the dessert and the wine came to an end, and it was Chapel time (mercifully). A number of men left-whether they went to Chapel or not may be doubted-but they went away, the host begging them to come back after service. Perhaps some did-I cannot speak from experience-and they may have "told bad stories and sung bad songs" as Thackeray says in his Book of Snobs. I can only say that I never heard either the one or the other. When the "wine" was given in college it was a far more quiet affair-and much pleasanter; and the small parties of this kind, where the host carefully selected his company, were simply delightful.

While on this subject let me not forget to mention the "wines" given by the tutors, and other Fellows of the college. They could be very formal and dull, if the tutor had not the art of talking, or failed to get a talkative Fellow to support him. And of course the undergraduates were very shy and spoke to each other in fearful whispers. Only now and then some audacious person, taking advantage of a dead silence, would prefer a sententious remark, such as: "Coleridge has well observed that Shakespeare is the only author in whose writings no word could be altered without impairing their beauty." Which remark, if ever made, is said to have elicited the rejoinder: "I suppose, Mr. — you would except St. Paul?" Another, equally unfortunate, occurs to me: "Is it true, sir, that when you were an undergraduate, you belonged to the Sabbatarian Shakespeare Society?" "No, we used to meet on Sundays," replied the tutor. But I can recall some Fellows to whose rooms we went with pleasure, where the welcome was cordial, and where the guests were drawn into conversation with no apparent effort, by the rare power of the host to make his guests feel at home in his society. I am thinking, as I write, of Professor Thompson, afterwards Master, and Mr. W. G. Clark. 


\section{The Reading Man}

On these fortunate occasions the hardest reader in College took a holiday; but, as a general rule, the typical reading man was back in his rooms by six o'clock, where he was sure of a good quiet time till eight or half-past eight, when he had tea, usually not alone. Some equally hard reader would drop in, perhaps by appointment, to talk about work; or, possibly, the two friends were reading some book together, and had arranged to meet every evening till it was finished. If no one dropped in, he would probably start, milk-jug in hand, for somebody else's rooms, in search for companionship. Then came bed, at about eleven, if the reader were a prudent man; but, as he most likely was not, at any hour, for conversation was pretty sure to succeed work, and lastly would come a walk in the cloisters.

Such was our division of time. It seems strange enough to modern ears; but, having regard to our exceptional life, it was not a bad one. For its realisation it required a state of things wholly different from what we are experiencing now. I mean, it assumed that we had the power of isolating ourselves from all interests except those that had to do with our work. We had no distractions except those we made for ourselves. I shall speak by and by, I hope, of the pursuits and amusements of those for whom the studies of the place had little or no attraction, but what I wish to insist upon is, that a man who wished to work in the fifties and early sixties had no impediments cast in his way by a diversity of interests.

Before I close this instalment of my recollections let me remark that between 1820 and (say) 1850, graduates, like undergraduates, could lead, and did lead, undisturbed lives. Some said that they were lazy, and when Mr. Beverley made his attack on Cambridge in 1833 he tried to persuade the world that they were also vicious. I believe neither accusation. Fellows of Colleges were not expected to take a share in the government of the University as at present. The Colleges were everything, the University a mere degree- 
giving corporation, governed by the Vice-Chancellor and the Heads of Colleges in reality, and by the Caput Senatus according to the Statutes, until the Act of 1856. Try to imagine an academic world without Boards, or Syndicates, or Discussions in the Senate House, or-may I say it without offence?-Marriage.

\section{III}

I said above I would return by and by to the subject of the Chapel question, as it would be called nowadays.

From what I have heard of compulsory chapels in earlier times, I gather that deans were sometimes-well-brutal. In illustration of this I cannot refrain from telling a story which my readers will perhaps have read for themselves in The Cambridge Tart-if their researches should have led them into the antiquities of University literature-but which I have the very best reason for knowing to be literally true. Let me add that in after years the official in question became a pious, hardworking parish clergyman. An undergraduate had been very irregular in his attendance at chapel. The Junior Dean sent for him. "What excuse have you for your absence from Chapel, sir?" "Please, sir, I felt no inclination to pray." "That's no excuse. I don't want your - prayers; I want to see your — face. Write out for me "-naming some long imposition. This dialogue took place at the very outset of the period I" have selected for illustration, and as the dean in question admitted in after years that the story was probably true, I set it down as evidence of the times rather than of the man. People were strangely violent in their language when I was young. I may take it that my readers have all either seen or read Sheridan's comedy The Rivals. Well, I have heard Sir Anthony Absolute described as a caricature. Caricature indeed-he is a photograph; and the original might have been any gentleman fifty years of age taken at random out of anybody's acquaintance. They were charming people, those old men-kind, charitable, good-natured, good-tempered, 


\section{Compulsory Chapel}

provided they were not contradicted or thwarted. Then, you might hear the tiles fly off the house, as I once heard such an one say of himself.

It does not fall within the scope of these random Recollections to discuss whether compulsory chapel be wise or unwise; but as a preface to what happened in my College in 1838, I will mention that, in May 1834, Connop Thirlwall, then one of the assistant tutors of Trinity College, in a "Letter on the Admission of Dissenters to Academical Degrees," had spoken of chapel as "the constant repetition of a heartless, mechanical service "; nay, further, he had asserted that, "with an immense majority of our congregation it is not a religious service at all, and that to the remaining few it is the least impressive and edifying that can well be conceived." His criticism was not merely negative; he advocated a weekly service, "which should remind the young men of that to which they have been accustomed at home." The pamphlet created a great sensation; the Master was terribly shocked, and requested the author to resign his assistant-tutorship; he did so, and then the academic world went to sleep again for a few years.

I cannot help thinking that 'Thirlwall's action must have had some connection with what happened next. It may be conjectured that his remarks would be widely read by those to whom they applied most closely, and that undergraduates would try how far they might venture to absent themselves from a service which they disliked, and now discovered that one man at least, older and wiser than themselves, agreed with them in disliking, at least so far as compulsory attendance at it was concerned. Whatever may have been the cause, in February 1838 the Master and Seniors of Trinity College agreed that all undergraduates " do attend Chapel eight times at the least in every week, including Sunday Morning and Evening; and that in case of failure the Parties under such default be forthwith admonished by the Dean, and if, after such admonition, irregularity be persisted in, notice be sent by the Dean to the Tutor, that a warning from him also may timely be given; 
after which, if both these means shall fail in producing regularity, the Offender shall be reported by the Dean, to the Master (or, in his absence, to the Vice-Master) to receive a formal Admonition from him, in the presence of the Dean, a record of which shall be preserved: and finally, in all cases, where such formal Admonition shall have been incurred three times, the Offender shall ipso facto be removed from the College, either for one or more Terms, or entirely, according to the circumstances of the case."

Hereupon was perpetrated one of the most audacious and, at the same time, humorous, outbursts of undergraduate resistance to what was regarded by them as tyranny. A number of undergraduates formed themselves into a society, which they called "'The Society for the Prevention of Cruelty to UNDERGRADUATES"; they took steps that a certain number of members should attend each service and take note of the attendance of the Master and Fellows. At the end of each week they published the result, arranged after the manner of a marker's sheet, with notes. The papers were printed, I believe, in Cambridge, but by whom and at whose instigation was never found out. Six copies were sent to each of the University clubs in London, and a large number were circulated in Cambridge. The issue of these papers continued for six weeksfrom 17th February to 24th March-after which they were discontinued, as the authorities had relaxed their requirements to a certain extent, but—so far as my researches go-not so far as the jubilant expressions of the last paper issued would warrant. I have, in fact, been told that the assertion in the notes to that marking-sheet, dated 24th March, to the effect that the Master and Seniors had agreed to "a new regulation which requires only Six Chapels to be ipso facto kept each week by the Undergraduates," was a forgery issued by the society. Perhaps both they and the authorities were glad to terminate the affair. No such regulation was entered in the Conclusion Book of Trinity College, and the regulations complained of were virtually in force for many a long year afterwards. At the end of 


\section{Compulsory Chapel}

the concluding paper the Fellows were arranged in four classes, after the manner of a College Examination; two were not classed at all, of whom "the secretary need hardly say that he does not envy them their feelings"; and a Prize Medal (as it was called) "for regular attendance at Chapel, and good conduct when there " was awarded to Mr. Perry, whose attendances had amounted to sixty-six. The "Medal" was a large Bible, which Mr. Perry, who afterwards became Bishop of Melbourne, valued greatly. I had the pleasure of meeting him after his return to England, and he told me that he always used the volume at family prayers.

The question excited a lively interest in college, and gave rise to various effusions in prose and verse. One at least of the former was decided to be profane (as it undoubtedly must have been), for it was a parody on the Litany, and the author was promptly expelled; another, which lies before me as I write, might be styled gross. But there is no harm in " A New Song to an Auld Fling," from which I will quote the opening stanzas :-

\section{I}

"He's lazy! he's lazy ! is old Greenwood, In his nest our sweet bird is singing;

Brown, Thompson, and Whistle are lazy of mood,

Though the Chapel bell is ringing.

\section{II}

Oh, Master best! our nightly rest

Is spoilt, is broken through;

And we must hold, through wet and cold,

To Chapel-and for you.

\section{III}

'Tis all on account of your notice so long And your many notanda so true,

That daily we're seen, hauled up by the Dean,

With our gowns and our faces of blue."

In the above verses "old Greenwood" is Robert Hodgson 
Greenwood, Senior Fellow in residence. He had taken his B.A. degree in 1791, and therefore in 1838 was about sixty years old. "Our sweet bird" is George Peacock, then one of the tutors, a man of wide cultivation and knowledge of affairs, deservedly popular with everybody. He became Dean of Ely in 1839. Brown ought to be John Brown, then Vice-Master; but possibly there may be a clerical error, and George Adam Browne, one of the Seniors, may be meant. Thompson is W. H. Thompson, then a junior Fellow, afterwards Greek Professor, and Master in 1866. "Whistle" was a nickname for William Whewell, then one of the tutors, and Master in 1841.

To come down to more modern days, I cannot claim for men in my own year that we were specially obedient; but I do not remember that compulsory chapels were found to be more irksome than ordinary duties, except perhaps to Scholars, who were obliged, when " in waiting," to read the Lessons for a week at a time. Some of us, on the other hand, felt that daily service was a duty not lightly to be neglected; and, though they did not wholly approve the way in which it was said, they took what was given to them, and were thankful. As a general rule everybody behaved with propriety. "Iniquity Corner," as the space at the east end on each side of the altar was called, may occasionally have effectually sheltered cardplaying; but when a young snob went so far as to light a cigar there he had the pleasure of finishing it in the country, for he was rusticated. It was on a cognate occasion in Jesus College, in which cobblers' wax played a prominent part, that Dr. Corrie dismissed the culprit, after a severe lecture, with these admirable words: "Your conduct, sir, is what a Christian would call profane, and a gentleman vulgar."

When I first began these Recollections I had it in my mind to deal at some length with the course of study which pre- 


\section{"Acts and Opponencies"}

ceded a degree, for during my period "old things passed away, and all things became new." But, on mature reflection, I have decided that the subject requires a volume all to itself. This latter treatment I hope it may receive before long from a far abler pen than mine. Meanwhile I will say only just as much as is required from my own point of view. I want to indicate-quite superficially - the nature of an undergraduate's work, especially in the first half of my period.

Mathematics held an undisputed supremacy in those University Examinations which led to a degree. The Mathematical Tripos was the only Tripos, and there was no preliminary examination of any kind. There had survived, however, from mediæval times, a system of syllogistic disputations, called Acts and Opponencies, to which every aspirant to a degree was obliged to submit. One or other of the Moderators sent for each student in turn, and assigned to him one out of three propositions, submitted by the student, as the subject on which he was prepared to write a thesis. The proposition might be Mathematical or Moral, and was stated in Latin, the language in which the whole procedure was conducted. Here are examples of both propositions:-

Recte statuit Newtonus in septima sua sectione libri primi ;

Recte statuit Lockius de Qualitatibus Corporum.

On a day appointed by the Moderator, the "Respondent," as he was called, attended in the Public Schools, and read a thesis on the propositions selected. The reading ended, up rose three Opponents, one after the other, and traversed the Respondent's arguments. He replied, and if the two were really conversant with the subject, and capable of quick repartee in Latin, with a Moderator who took a pride in stage-managing the performance (for such it was), a brilliant entertainment was provided, and the school in which it took place is said to have been crowded with enthusiastic listeners. This favourable view of the proceedings is given on the authority of Bishop Watson, who was Moderator in 1762; and Mr. de Morgan, 
who was fourth wrangler in 1827, records that in his day: "The real disputations were very severe exercises. I was badgered for two hours with arguments given and answered in Latin-or what we called Latin-against Newton's first section, Lagrange's Derived Functions, and Locke on Innate Principles. And though I took off everything, and was pronounced by the Moderator to have disputed magno honore, I never had such a strain of thought in my life. For the inferior opponents were made as sharp as their betters by their tutors, who kept lists of queer objections drawn from all quarters." 1

A shaky student was occasionally prompted by his private tutor, and that too, under the very eyes of the Moderator, by the help of a cleverly arranged code of signals. I have good authority for the following story. The tutor, an Italian, and therefore a master of dramatic gestures, said: "I shall sit in the gallery; when I button my coat, so, you will say, Nego minorem: but when I throw it open, so, you will say Cedo majorem."

When the Moderator considered that the questions had been sufficiently debated, he dismissed the Respondent with the words Optime quidem disputasti, or Optime disputastiwhence the division into Senior and Junior Optimes. The Moderators took careful notes of these performances, and sorted the candidates for the B.A. degree in accordance with them into as many classes as they thought proper. These were modified by examination-in the modern sense of the word; and, finally, the order with which we are familiar was settled. The "Polloi," or ordinary degrees, came last, the names being sorted into not more than four classes, and arranged alphabetically in each class. It was provided by a Grace passed in $\mathbf{1 7 9 1}$ that their names should not be printed.

Mr. de Morgan, in the passage which I have just quoted, speaks of "real disputations," words which imply that some were unreal; and such no doubt there must always have been.

1 Budget of Paradoxes, p. 305, quoted by Wordsworth, Schola Academica, p. 63, note. 
Imagine everybody, clever men and stupid men, hard-reading men and idle men, compelled to grind corn at such a mill! No wonder that many failed, and that for some, the evidently incapable, a sort of parody of a disputation was allowed, called "huddling." And yet the system died hard-it did not come to an end until 1840-and I have heard Dr. Whewell say, in a tone of regret, that "men's wits were sharpened by it." As for the language used, well might Mr. de Morgan smile at "what we called Latin." It was probably as little like the genuine article as the mediæval Latin which we find used in College Accounts-where a countryman is homo de patria, and so forth. Indeed it is stated, I know not on whose authority, that a dog having strayed into the Senate House, his immediate expulsion was ordered in the words, verte canem ex.

While the University was engaged in supporting these curious ceremonies-what a Carlyle might have called mediæval old clothes-the Colleges, or some of them, were doing their best to instruct their men in Classics. In my own College, for instance, it was a matter of tradition to educate in Latin and Greek, and the instruction given was of a very high order: the annual examinations were strict, and, in the election to Fellowships, classical attainments which were not recognised in the Senate House were taken into account. As time went on a public examination in Classics was established. This took place in 1822, and the examination was called the Classical Tripos; but it was clogged with restrictions. No man might enter it unless he was at least a Junior Optime - a rule borrowed from the Chancellor's Medals, founded 1751 by the Duke of Newcastle, for which every candidate was required to be a Senior Optime-so that it was no avenue to a degree. When the Moral Sciences Tripos and the Natural Sciences Tripos were instituted in 1848, the condition about Mathematical Honours was not insisted upon, but a candidate was still required to have obtained the degree of B.A. Subsequent legislation set all these Triposes free from restrictive conditions, and encouraged the development of individual tastes and 
acquirements - a movement which in our own time reached the Special Examinations, established in the place of the old Ordinary Degree Examination, which was a strange combination of incongruous subjects, with a Professor's course of lectures thrown in as a make-weight.

The requirement of attendance at Professors' lectures is said to have been invented by Dr. Whewell in order to provide the Professors with an audience. Every candidate for an ordinary degree was obliged to present a card signed by a Professor to certify that he had duly attended his lectures and passed an examination in them. Whewell had a very high idea of the value of professorial teaching. "Such lectures," he wrote, "tend to make the hearer feel that he is a sharer in the present as well as the past progress of literature and science; that he is a citizen of an intellectual republic, which has the advancement of knowledge, and the discovery of truth, for its constant aims. The charm which belongs to such lectures, when they are delivered by able and diligent Professors, will often take a strong hold upon the mind of the intelligent student, and impart to him a fervour of thought and a largeness of comprehension which cannot be communicated in any other manner." All this is very true, but the enthusiast who wrote the above passage forgot who the hearers of the Professors were to be, and the result was very different from what he had imagined. I, for instance, attended a course of lectures by Sir James Stephen on the foreign policy of Louis Quatorze, delivered with the solemnity of which he was master, and in language far above the comprehension of the young fellows who sat below him. At the close of the lecture we dropped our cards into a dish placed on a table below the Professor's desk. 'The number of cards was usually the same as the number of the class, but I am afraid that we did not always confine ourselves to our own cards. If a man wanted to shirk it was not difficult to find a friend who would leave two cards instead of one. Then came the examination. Towards the end of the course the Professor told us that we 


\section{Professors' Lectures}

were to be examined in Guizot's History of the English Reformation-a work which may be of great historical value, but is repulsively dull, especially in the English translation which we were expected to use. I did my best to get it upin the midst of other and more pressing studies-but when I entered the examination room, behold, our learned Professor had set a paper of the old form, on a large folio page, closely covered with a set of very searching questions. "All is over," I said to myself. "I must be plucked." I wrote very littleand that little was sad stuff-but I was let through! The truth was that all the Professors hated this system, and did their best to evade it. "I make a rule never to pluck a gentleman twice," said the Professor of Political Economy. When these noble sentiments became known in the University, his lecture-room was crowded. Before long the University appointed an assessor to each Professor-a sort of dragonto prevent him being too easy in the matter of examination.

Before this unfortunate move of Dr. Whewell's had passed into law, certain Professors were successful in obtaining large audiences of voluntary students. Such were E. D. Clarke, whose lectures on Mineralogy were crowded; Professor Henslow, and Professor Sedgwick. The two last laid the foundation of our Natural Science School. Both were men of great personal charm, and both laid themselves out to attract any undergraduates who showed promise. In the house of the one, and the rooms of the other, the lamp of science was kept burning at a time when good people thought it "dangerous," and when even broader-minded divines were exercised about the reconciliation of geology with the Mosaic cosmogony. When Sedgwick had his famous controversy with the Dean of York at a meeting of the British Association, Hudson, the "Railway King," as he was called, is reported to have said, "If it comes to a vote, I shall vote for the Dean and Moses." And probably the people of this country would have placed those two persons at the head of any poll, by an enormous majority.

This sketch has been, I hope, sufficiently detailed to show 
that in what I may call the old University course there was little to attract the average man. A mathematician had plenty to employ his time, and a diligent classical scholar would find three years too short for all he wished to read. But for the rest, what was there?-rowing, cricket, and riding, and, after 1840, football, as has already been mentioned. For instance, what did the "bloods," or fast men do? They played at billiards, but not in Cambridge. Oh! no-the pure atmosphere of the academic groves must not be sullied by that profane game; but at Chesterton, out of bounds, so to speak, it might be indulged in-and was, under the patronage of the once celebrated Wonfer-or on the Grantchester side of the Barton Road. There was tennis, too, but only to a very limited extent, the old collegiate courts having been pulled down. Quoits are said to have been played occasionally on Clare Hall Piece, the green space immediately to the west of the College. The mention of this Piece reminds me of a pleasant old custom. On Commencement Sunday the whole academic world used to walk up and down there for half an hour after the University Sermon, and a very pretty sight it was, Mr. Vice-Chancellor and all the Heads and Doctors in scarlet, and the ladies in their best frocks. In the days to which I allude personal attendance was required at "creation," as it was called - that is to say, every man who had taken one of the higher degrees came to Cambridge and was formally "created" by the Head of his Faculty, or by the Senior Proctor, in the Senate House. It was a time of festivity in a quiet way, and much looked forward to as the last occasion when all the men of a given year had the chance of meeting each other. But I am deserting my "bloods" and their amusements. In winter they had hunting, and freely did they take advantage of the proximity of Cambridge to several good packs of hounds. Then there were steeplechases occasionally, very much forbidden, and now and then successfully interdicted by a vigorous proctor; and last, but by no means least, Newmarket. I am afraid that I should not be a truthful chronicler 
if I did not admit that there was always a good deal of gambling. A popular game of chance would certainly be played for ever-increasing stakes till somebody was "broke" and could not pay his losses, or somebody was accused of cheating others, and then there was a serious row, which lasted for a longer or a shorter time according to the standing of the players, or until the intervention of common sense in the person of a man of the world, who affected to look into the facts, and then whitewashed everybody, accusers and accused alike. I must admit also that in earlier times, when drinking-bouts were the fashion in good society, they were also the fashion in Cambridge. I have heard of feet being broken off glasses in order to ensure the drinking of bumpers, but such a prank as that belongs to the days when a song, a toast, or a sentiment was demanded of each person in company, and was out of fashion long before my time. I can say, with perfect truth, that though I may have seen men "happy" at a dinner party, I never saw anybody in that condition which once upon a time was called "glorious."

Here I must stop for the present-I had intended to say a great deal more about the pursuits and amusements of those who could not be called either reading men or fast men. I should liked to have spoken of the Union and other debating societies, the Theatre, public and private, the interest taken in literature at different periods, and to have mentioned some of the distinguished men who have from time to time adorned our Colleges. I think, as I write, of Thackeray, of Tennyson, of Arthur Hallam, of Mackworth Praed, of Lord Houghton, and many others, about whom it would have been a pleasure to collect a few facts. And then there is general society. It would have been a very real pleasure to me to try and draw a picture of what that was in the days before the new Statutes had "cried Havock, and let slip the dogs of war." Our quiet little preserves must have been very like the Ancien Régime before the Revolution; or Italy before Napoleon upset the old order of things. 
Up to the present, in my "Recollections," I have confined myself, more or less closely, to the education and amusements of the place. I must now try to describe what the general society was like; and, in the first place, let us consider how very small it was. Let us begin by opening the Calendar for 1842, when I was nine years old. My father and mother were very fond of society, and if anybody was worth knowing I am sure they knew them; but, so far as I can make out, they could not possibly have been on visiting terms with more than sixty ladies, if so many. In the first place, there were seventeen Heads of Colleges-we will go minutely over these later on; then there were twenty-five Professors, and eleven residents in Cambridge, Commorantes, popularly called "Cormorants." Now what steps did they take to see anything of each other? In the first place, there was the perpetual morning call; secondly, the evening party ; and, thirdly, the great staple entertainment, a dinner party. Mrs. Jones was not on proper visiting terms with Mrs. Smith unless she had been invited, with quite long notice on a card, not infrequently coloured a delicate pink or a light azure. Moreover, there was an unwritten code of laws which governed a dinner party. I will try to describe one. We will suppose a lady and gentleman are sitting by their dining-room fire. "My dear, I think we ought to give a dinner party." "Do you? I don't think we owe anybody anything." It must here be said that nobody dreamt of issuing invitations because they wished to see people, but merely because certain rules of society had to be obeyed. If you lived in Cambridge in a certain position, you had to entertain. There was no way out of it. It had to be done. "If you look more closely into the matter I think you will find there are some people at whose feet a dinner ought to be laid." "Very well," with a certain asperity of tone, "I will go and find my pocketbook and then we will see." I need hardly add that the 


\section{A Dinner Party}

husband was right, and as there were several persons of European reputation for learning who had not dined in their house, a dinner party was agreed upon. Further, I must not omit to chronicle the fact that this dinner-giving went on and on, and there was no end to it. You had no sooner finished one batch than you had to begin with another.

The number selected was usually about sixteen or eighteen, consisting of six couples, the master and mistress of the house, and four of the pleasantest bachelors available. In making the selection many things had to be considered. If it was Lent, you must be careful not to ask a High Church Professor of Divinity on a Friday; and, further, a Friday was dangerous because the "Family" met on that day. Monday was sacred to the Philosophical Society; and, as Natural Sciences became popular, Wednesdays were consecrated to the Ray Club.

At last the guests are completed, and host and hostess await in fear and trembling for the almost inevitable disappointments at the last moment. It ought to have been easy enough in so small a place to get people to fill up, but it was not; and I have heard a lady who came at the last moment say, in the midst of a dead silence, "Pleasant party this. We don't belong to it. We were only asked this morning."

Now you must know that the food and drink and the appearance of the table were all totally different to what they are now. As regards the first of these, the host had to resort to his college kitchen, and there appeared a dinner about twice as substantial as was necessary. The wine also, at most houses, was served with great liberality. The table alone was badly furnished, and looked poor and starved. When the guests were ready to go into the dining-room (places, it should be remarked, were not allotted) a man was told what lady he had to take in, but he sat himself down where he pleased. People used to pride themselves on getting a seat next to a pretty and agreeable woman. When the places were all filled, it was observed that opposite the lady of the house there was a tureen of soup; opposite the host, a fish. Then there were 
four entrées, and, if you wished to be very generous, two more dishes, which, because they were put one on each side of the table, were called "flanks." Says the gentleman who had taken in the lady of the house, "May I have the pleasure of helping the soup for you?" Poor woman, how could she say "No"? But the function was usually somewhat disastrous. Probably her gentleman began to talk and pay more attention to the conversation than his work. It is also not improbable that the waiter was the worse for some previous imbibition, and in handing the soup would pour a whole plateful down her back. I don't know what ladies said on these occasions, but once when a bishop was deluged with gravy he exclaimed, "Is there any layman present who will express my feelings for me?" The soup disposed of, the host attacked the fish, and, if it was summer-time and he was an enthusiastic slayer of salmon, he made the distribution of that unfortunate fish a somewhat tedious operation. Next of all, the entrées were handed; after which the remains of the soup and the fragments of the fish were taken away and replaced by the inevitable boiled turkey and roast haunch of mutton. Here again some unhappy guest was expected to assist the lady. These dishes disposed of, came a course of game-a roast hare and a dish of snipes-after which an interminable procession of sweets, followed by cheese and ale. As regards the liquor imbibed, one began with sherry. I have heard my mother say that, when she was a girl, there was a pint decanter of sherry or a pint decanter of Madeira between each two persons. The wine was not handed, but a gentleman who wished to be civil to the lady he had taken in to dinner asked her to do him the honour of drinking wine with him. Towards the end of dinner a small quantity of champagne was served, but I need hardly say that during the French War there was not much of it.

By this time the dinner had lasted about two hours, and the guests were beginning to long for the real business of the evening, their port wine. Then the cloth was drawn, and the butler went round with a napkin in his hand, begging the 


\section{$A$ Dinner Party}

guests to move a little so that he could get between each pair so as to belabour his beloved table and remove the stains made by the hot plates and dishes. Then an elaborate dessert was put on, a dessert which the lady of the house had arranged in the morning and given a plan of to the local greengrocer or other functionary who had been hired to look after it. By this time the table had begun to look very gloomy unless the host chanced to be the lucky possessor of several pairs of silver or plated candlesticks, as gas, it nust be remembered, was not in general use. I think I have already mentioned that nothing bright or pretty was permitted on the dinner table: no flowers were allowed. I don't know why, but the fact remains that there were no bills of fare. You were expected to eat everything with a thankful and grateful spirit, only nothing was to be allowed to interfere with the supreme duty of life, your port wine. Woe to you if you were seen eating sweets. I once heard an old gentleman say, "Sir, do you presume to give an opinion upon port wine such as this when you have got half a preserved orange in your mouth?" The gentleman who uttered this noble sentiment was a splendid specimen of a bygone age. I once saw him at dinner in knee-breeches, and he was almost the only person that I ever did see in that most becoming costume.

When the whole party had returned to the drawing-room, and the conversation was at its height, we used to have a little music. What I am now about to tell you is almost incredible, but I can assure my readers that I have not distorted or exaggerated in any way. I have told you that no one was ever asked to dinner without the almost certainty of a return invitation; but, if her room was a large one, the lady of the house took care that it should be filled, and she accordingly invited a certain number of ladies and gentlemen to come in after dinner to play and sing for the amusement of the company. They usually sang romantic and sentimental ditties: the wrongs of Ireland and the woes of Greece were set forth at length; and sometimes the lady of the house herself, armed 
with that awful instrument called a concertina, used to play duets with another lady, similarly provided. There was a good deal of free-and-easiness in this mode of entertainment, and the Heads of Colleges detested it all the more because it was unfettered by any of their own rules and regulations. Instances have been known of their leaving a room where such profanity was permitted. 'These interlopers had, I know, to be fed, but it was not necessary to provide them with anything very luxurious. It has been estimated that four such parties, of ten or twenty people each, could be given for one sovereign! The food consisted of a few sandwiches, the top of the sponge cake, of which the lower part had already been consumed at dessert, the fragments of the jelly, cut up and put into glasses, and a little lemonade and white-wine-negus to wash it down. It might have been thought almost impossible to persuade ladies and gentlemen to come on these terms, but I could single out two ladies especially who had no hesitation in obliging those who did not scruple to entertain them in this supplementary fashion. In future times the husband of one became a successful mathematician, and the husband of the other an equally successful Poll "coach."

At this point let me tell a story. The first of the abovementioned ladies, with her husband and her family, spent two or three months of a summer in a French watering-place. While there they became exceedingly intimate with some University people of a social rank which they considered to be considerably below their own. So, a day or two before leaving, the lady called on the friend whom she thought so second-rate, and, after regretting that they must know so little of each other in the future, said, "You see, dear Mrs. So-and-so, the differences in our University rank will make it quite impossible for us to meet as we have done during these delightful summer weeks." Mr. H., as we will call him for convenience, the husband of the lady who made this remarkable statement, was among other things an exhibitor at the Exhibition of ' 51 , and, in that capacity, was honoured by an 


\section{A Morning Call}

invitation to the ball given by the City of London to the Queen and the Prince Consort. Mrs. H. happened to be in deep mourning for her mother, and her lady friends in Cambridge were very curious to know how she would manage the difficult question of dress. That she would go they felt certain; but how would she deal with the arduous question of etiquette? So, a few days afterwards, she was called upon by several of her friends, who eagerly inquired what she had done. "Did you go in colours, my dear?" "Not altogether." "But, of course, you could not appear before the Queen in black." "No, of course I could not; but I found a way out of the difficultyI did not take off my black silk stockings."

This same old lady used to do all the family housekeeping, which was carried out in a much more simple and straightforward manner than it would be at the present day. On returning from market one day, this ancient dame paid a morning call, and presently, observing that her friends were looking at her, she sprung to her feet, screaming "Dear me, what are you all looking at? Why, surely that must be an eel on the carpet there?" And sure enough it was. She had in the first place put it into her pocket, whence it had made its escape, and was now wriggling over the drawing-room floor. 


\section{CHAP'TER III}

\section{J. AS A BOY}

I Now return to my sketch of J.'s childhood. I can find little information about his private school, if indeed he ever went to one. In 1844 he took lessons in Hullah's system, and was "drilled by Mr. Reed"; in April of the following year "Johnny went to Mr. Woring's." Was this a private school? In 1846 he was certainly learning to ride and "attending an academy" -possibly of dancing-in Cambridge.

"I have never remarked," said Dr. Alexander, then Bishop of Derry, in preaching at St. Margaret's, Westminster, on St. John the Baptist, "I have never remarked that the only sons of elderly parents are particularly remarkable for self-abasement." J. was an only son and his parents were elderly.

I feel sure that he was spoilt; he indeed remained a spoilt child to the end of the chapter, and although he ate but sparingly, he would be humorously petulant even in later life if some hostess had, in her ignorance, provided certain dishes he did not like. He used to pretend they had been ordered especially to annoy him. As a little boy he was very lonely. His father discouraged him from making friends or even acquaintances amongst those of his own age, and a boy can't always be bothering with grown-up people and grave dons. He sometimes talked to me of the tedium of his boyhood and of the restrictions which in early Victorian days it was thought well to impose on the young. He was lonely and friendless, and I think that both at home and at Eton he was, well-not happy. There is a pathetic paragraph in a letter ${ }^{1}$ to Mrs. Pemberton of Trumpington Hall, referring to her mother: "For me, she provided

1 Dated Scroope House, October 22, 1899. 


\section{Trumpington Hall}

all that was pleasant in my dreary childhood. I used to look forward to a visit to Trumpington under her régime as a sort of paradise, where I found friends and endless pleasures denied to me elsewhere." The kindness J. had received at Trumpington Hall is further shown by the following extract from a speech he made at the coming of age of Mr. Francis Pemberton in $1906:-$

"Let me think-when did I first enter that dear old house, which to me as a child, happy to escape from the dullness and stiffness of the Cambridge of that day, seemed ' a pleasant place of all festivity,' and which has never lost its charm? It was on the 10th of January 1844, and we guests, who came expecting an ordinary children's party, were gladdened by the sight of what was then a complete novelty, a Christmas-tree. It was fixed to the centre of the dining-room floor-some of us thought it grew there-and it touched the ceiling. It was laden with French bonbons, and of course lighted by a profusion of wax tapers. French bonbons were at that period as rare as Christmas-trees, and I believe that the ruins of some of those which were given to me on that occasion are on my chimney-piece at the present moment.

"Who were our hosts that evening? In the first place there was the owner of the estate, Colonel Pemberton, with his delightful wife, whom I remember most distinctly in old age, when she used to amuse us of the younger generation with stories of her far-off youth, when George the Third was king. Stories did not lose in her hand; and though I would not for the world say that she was ever ill-natured, there was a slight suspicion of malice in the way she turned her phrases which was quite delicious. . . .

"There were present, of course, Captain and Mrs. C'ampbell, the father and mother of our hostess to-night. Of the Captain I remember little; but Mrs. Campbell, as I still prefer to call her, whom you all know as Mrs. Pemberton, was the friend of my boyhood and the friend of my manhood. In a life that has now grown to be a long one, I think that I never knew 
anybody quite like her. Others may have been as clever, as well-informed, as generous; but she combined all these excellences, and added to them a charm of manner peculiar to herself, which made her a perfect hostess, and a perfect Lady of the Manor.

"Nor am I likely ever to forget the boy for whom the party was given-her eldest son, Frank Campbell. I was three years his senior, being eleven years old when he was only eight; and from that proud eminence I contemplated with some jealousy his blue velvet frock, which I thought much more picturesque than my own. I suppose we must have met on some previous occasion; but if so, I have quite forgotten what it was. It is from that evening that $I$ date our friendship, which lasted unbroken until his death."

On the 19th April 1847, J. went with his mother to Eton, where he entered at the house of William Johnson. On the following day Johnson addressed the following letter to Dr. Clark :-

\section{Eton College, 20th April 1847.}

"Dear Sir,-I am very glad to be able to tell you that your son's examination terminated this evening successfully, as he was thought by Dr. Hawtrey fit for 'the Remove,' so that he is placed as high as any one can be, and as the half-yearly promotion takes place on the 9 th of June he will be in the fifth form unusually early. ... Yours faithfully,

William Johnson."

As I have said before, I do not think that during his four years at Eton, J. was happy or content. He did not understand other boys-how could he? The Eton life was at that time rough and hard; he had a very quick temper and was bullied, and probably as he grew bigger retaliated in kind. One or two friendships seem to have been nipped in the bud by the interference of his elders. He had no athletic qualifications such as would attract the regard of his schoolmates, and I, for one, am not surprised to find in almost all the letters from 


\section{Eton}

school a careful estimate of the time which must elapse before he could leave the place and return to Cambridge.

Later in life J. became an enthusiastic Etonian, and developed a deep affection for his old school. He fittingly included in the Architectural History an account of its buildings. He constantly revisited the College, and served upon many a committee connected with it.

J.'s tutor, William Johnson, who later changed his name to Cory, was a stimulating and interesting master, and a writer of delicate poems, full of thought. He was, as one who edited his poems, Ionica, writes, "for many boys a deeply inspiring teacher; he had the art of awakening enthusiasm, of investing all he touched with a mysterious charm, the charm of wide and accurate knowledge, illuminated by feeling and emotion. He rebuked ignorance in a way which communicated the desire to know. There are many men alive who trace the fruit and flower of their intellectual life to his generous and free-handed sowing. But in spite of the fact that the work of a teacher of boys was intensely congenial to him, that he loved generous boyhood, and tender souls, and awakening minds with all his heart, he was not wholly in the right place as an instructor of youth. He was for ever trying experiments; he would read a dozen books to enable him to give a little scientific lecture, for he was one of the first to appreciate the educational value of science; he spent money on chemical apparatus, and tried to interest the boys by simple demonstrations." 1

Like all men who keep diaries, Johnson not infrequently bemoans his unfitness for the career he had chosen, but in truth he must have had a real gift for teaching and awakening the interest of boys. He retained his Fellowship at King's until 1872 , and on his visits to Cambridge usually sought out J. On the 17th of September 1865, he takes two young guests to see the Geological Museum, and "thence I marched them to the Comparative Anatomy, and luckily found

${ }^{1}$ Ionica, by William Cory, with Introduction by Arthur C. Benson (London, 1905). 
my old pupil, J. W. Clark, setting up things in the workshops, probably things he had brought back from Denmark, where the great Steenstrup gave him (and he showed us) a sucker of the biggest of all pieuvres. ${ }^{1}$ In a bottle he had the head of a common one. He respected me for having seen a live one at Nice, and for telling him the Norman name of the beast, 'Minaur.'"

Again, in 1867, during one of his recurrent periods of selfeffacement, Johnson writes: "I never call upon the Fellows of Trinity except to get a lesson in anatomy from my old pupil, J. W. Clark." ${ }^{2}$

Mr. Oscar Browning went to Eton as a Colleger in 1851, and left in $\mathbf{1 8 5 6}$ for the sister Foundation of King's, his gown having been duly sewn up and then, as the ceremony was, "ripped" by the Provost of Eton. J. came into residence at Cambridge in 1852, and thus, although a little later in joining and a little later in leaving Eton, Browning's career overlapped that of J., and his vivid description ${ }^{3}$ of the life and surroundings of a Colleger in the middle of the nineteenth century gives some idea of the harsh conditions of life of a King's Scholar at that time. The lot of the Oppidans was happier, but still very different from that of the schoolboy of to-day. Mr. Browning's description of the food and the washing facilities in College fall somewhat behind, but as regards the latter but little behind, those of Dotheboys Hall; but we must not forget that adequate baths are only now being slowly provided in the Colleges of the older Universities. It was only last year that a venerable Head of a House at one of the older Universities, ${ }^{4}$ on the subject being broached at a College meeting, exclaimed with some acerbity: "Baths! Why the young men are only up eight weeks!"

1 Cuttle-fish.

2 Extracts from the Letters and Journals of William Cory (Oxford, 1897). (Privately printed.)

Memories of Sixty Years at Eton, Cambridge, and Elsewhere (London, 1910).

- Not Cambridge. 
Mr. Browning had a very keen appreciation of the teaching and the influence of William Johnson, "one of the ablest men who ever devoted his great powers to the service of education."

J. boarded with his tutor, who then held the boardinghouse on the southern side of the second archway on the left, after you have passed Barnes Pool Bridge going towards College. Originally this house was part of the old Christopher Inn, the stables of which, on both sides and at the end of the yard, were for years used as livery stables by Charley Wise, père et fils. After J. had left, Johnson passed on house and boys to his brother-in-law, the Rev. F. Vidal, remaining himself a lodger, and to some extent also a boarder. His sister, Mrs. Vidal, was a lady of some distinction as a writer.

During the Easter Vacation of his first year at Eton, J. dined at the High Table in Trinity with Professor Sedgwick, always, like Thackeray, a kindly friend to boys. I wonder if they had rump-steak and apricot omelette, which the latter considered to be the proper food for his schoolboy friends.

Some scores of letters have come down to us written by Mrs. Clark to J. at school, and as many from the schoolboy to his parents. His father wrote less often, but always in an affectionate manner, and ever showing a deep interest in his boy's studies and an intense wish that he should make good progress.

Mrs. Clark was a most spirited letter-writer. She was as outspoken as Mrs. Drummond-Ogilvy of Allardyce, Catriona's kinswoman, and her letters have the same quality of frankness. If I were attempting to write her life and not her son's, I should wish, instead of quoting a few sentences, to reprint them all and in full. Except for a few affectionate phrases, such as "My dear little boy" and "don't get up a fit of measles to coax Mummy down to Eton," she writes to her son of fourteen as if he were, to say the least of it, grown 
up. She was a keen horse-woman, and discusses her horses at great length with him :-

20 th February 1848.

"The horses are in excellent order. We have struck out some new rides lately, but fear they will be ploughed up before you come. You will remember a field on Shelford Common, near Dr. Kitling's, in which we used to get a gallop last year. We turned into that the other day and followed a field road in excellent order, which brought us out at Hauxton Gate; we then turned round and took off in another direction, and came out at Shelford, opposite Mr. 'Twiss's. Another day we tried a field about half-way on the far round, and came out below Lord Godolphin's.

"A new fair Equestrian has appeared, about whom I am very curious. She rides a clipt horse of bad action, bumps fearfully (nay, flies from her saddle at least a foot) in a canter, and is accompanied by a gentleman (not a good rider) and a large black dog. They neither of them appear to have any hand on a horse, but straggle about in a strange manner. They passed me on Parker's Piece near the Gaol. I thought they were making for the University Arms, when lo! I discovered they meant to go through the posts to Downing Terrace!!! Papa would call this "crossing the country."

20 th June 1848.

"I send you the Post Office order for the sum you named, and it is, as before, in your Papa's name. At the same time I must tell you we do not quite approve of your boating, nor are we without our fears for your safety. You are so inexperienced a swimmer that it is not to be expected you could save yourself in your clothes, which you must know add considerably to your difficulty, and then, as you are so unaccustomed to the management of a boat, there is every fear that you may not be always able to keep your balance.

"I shall be sorry if you take to boating as many lads do, because I think it injurious to the health and productive of idleness: still, of course, in moderation there is no objection to it, and you know I should wish you to be 


\section{Letters from Home}

able to do everything. Cricket, I suspect, you will never follow, but I hope you will always prefer riding to any other amusement, and hunt (if railroads do not destroy the country too much) when you can!!

"I hope you will not give up swimming and bathing now that you have passed, as the first requires practice and the latter is good for your health.

"We took our last ride on Saturday; it was a sultry day, and by the time we had walked to Trumpington the clouds threatened a storm. We turned back, came along the Fen, till deterred by a band of Savages, went to Trumpington again, along the cross road to the gate, and then home."

Mrs. Clark was an enthusiastic gardener and a very successful exhibitor at the local flower-shows. She spent hours in her garden, and was particularly successful with roses. When there were no flowers to tend, she would spend the afternoon in the vinery "painting stakes." In her letters to J. there is almost always some reference to the garden, and to her J. certainly owed his talent for cultivating flowers and his passion for roses.

Another feature of Mrs. Clark's correspondence is the gusto with which she describes social events and little local scandals. As a sample, I may quote from a letter dated the 20th of February 1849 :-

"We have been very gay. Mrs. Williams gave a very nice party on Friday; the following day Dr. Fisher had a ball-this was not so much to my taste as the company was not very select, and seats were very scarce. On Thursday Mrs. Prest had a ball, very well managed indeed; the drawing-room carpet was covered with that unbleached linen which is so much used now, stretched quite tight. 'The only drawback to the pleasure was that the house shook so fearfully; and the windows rattled so, that it could only be compared to a storm at sea. Many expected the floor to sink; it was impossible to sit at the end near the fire-place. I fully expected the dining-room ceiling would have fallen in; however, it all went off well. "There was to be another grand ball in Downing last 
night, at Mrs. G.'s; you may perhaps remember she lost her husband ... thirteen months since. She has now laid aside her widow's cap, and, to the great scandal of all steady people, dances with anybody, dresses in white, and has now given a ball.

"Our Ray ${ }^{1}$ on Wednesday was very good indeed, 22 in all. Professor Cumming came for a meeting at 'Trinity Lodge on Thursday.

"Mr. Cartmell was elected Master of Christ's on Thursday; we called on him yesterday; it is reported that he is going to be married."

In this case rumour proved to be correct, but even now everyone seems to expect that the moment a man is made Master he should rush out and marry the first maid he meets.

Later in life there were times when Mrs. Clark fought J. with all the vigour and tenacity with which the implacable old Mrs. Knox of Aussolas fought her grandson, Flurry; but all through her life (again like old Mrs. Knox) she fought her servants with amazing acrimony and vigour, and with such success that time after time she put them all to flight, and she

1 As this letter contains the first mention of the Ray Club, it is well to give a short account of a Club which has played no small part in the advancement of Science in the University during the last three-quarters of a century. The Club had its beginnings in certain "Friday evenings" held during full term in Professor Henslow's rooms from 1829 until the end of 1836. These "evenings" were frequented by both senior and junior members of the University interested in Science. On their discontinuance, they left a void, and early in 1837 certain senior members of the University, prominent amongst whom were Mr. C. C. (later Professor) Babington and Mr. (later Professor Sir G. E.) Paget, resolved "to form a Society for the cultivation of Natural Science by means of friendly intercourse and mutual instruction." Rules were drawn up limiting the number of members to twelve, and at the first meeting of the Club it was decided to call it after "the celebrated John Ray," the great Trinity naturalist. The Club met once a week, and dined annually on the 29th November, "the supposed natal day of John Ray," in the rooms of one of its members. In 1842 certain rules were added to the original "Laws" admitting a defined number of undergraduate and bachelor members, and these new rules have proved of the utmost benefit to the Club. 


\section{Letters from Home}

and Dr. Clark were left in their hour of victory alone on the field of battle, dependent for the commissariat department on the intermittent attentions of a casual charwoman. Much of Mrs. Clark's correspondence dwells in detail on the delinquencies of her staff, but these letters are scarcely worth reproducing. After a devastating encounter, when all the men-servants but the gardener were routed, and the females put out of action, Mrs. Clark writes to J. (6th March 1848) :-

"I forgot to tell you our arrangements. William pumps and cleans boots; papa brushes my habit and his own clothes, lights lamps, and very often shuts the shutters. I do most of the errands and open and shut bedroom windows, \&c., and Eliza does everything else. Ray answers the front door, but does not, I find, take the trouble to ask anyone for their name. Mrs. Kidd cooks joints and makes pies, and we live on them till she comes again. Ray shows a great inclination to muddle about in the kitchen, which I dislike and discourage, but, I fear, do not prevent. Don't comment on her conduct in your letter, as papa is sufficiently annoyed by it without being reminded. We neither of us think she will stay long, and really her constant illhealth makes it little desirable, as she is always under Dr. Bond's care."

And on 20th February 1850 :-

"The new housemaid arrived on Thursday. She is short, and so tight-laced that scrubbing seems to take away her breath. She appeared in a very pretty, gaylooking gown, a very long waist, with an absurdly long peak, a little mousseline de laine apron, very full, a scarlet neck ribband with long ends, and a very smart cap. Of course I read a long lecture on dress and had the neck-tie removed. She told Higgs she had always been accustomed to wear one of an afternoon, and a velvet in the morning—a genteel undress!!"

The following letters give a very spirited account of the festivities in connection with the Prince Consort's installation. Although the letters are long they are worth printing, 
as they give a contemporary record of what must have been a very great occasion in the University, and reveal many features of Cambridge life in the middle of the last century :-

4 th July 1847.

"We are all in bustle and confusion. Cambridge seems turned upside down. Up to last night there was nothing to be seen but paint pots, ladders, and every symptom of cleaning and ornamenting. ...

"There is a splendid triumphal arch at the end of the hospital grounds, where the pavement ceases. . . . It is nearly as high as the houses, and it is intended to screen the Fitzwilliam so that Her Majesty when she emerges from the arch may be astonished at the unexpected effect.

"To-morrow I am to go with Mrs. Fisher to the gallery at ten. Papa will go at twelve to Trinity to receive Her Majesty. . . . After dinner I must cut roses and make up my bouquet till dark. At ten we go to Parker's Piece to see the fireworks.

"On 'Tuesday I must finish my flowers by nine-there is then the Senate House from half-past ten. At two there will be the Horticultural Fête in Downing, and at six we are to dine in Trinity College Hall with Her Majesty. The party will necessarily be very limited. It is confined to the ladies of the Heads of Houses and Professors. We are to meet in the Combination Room, where Mr. Carus will receive us, and when dinner is announced he will marshall us two and two. The Chamberlain will then announce the Queen, and we are to receive her standingafter dinner we are to retire to Mr. Carus' room till nine, when we are to be presented to Her Majesty.

"On Monday Her Majesty is to dine at Catharine Hall: they have taken down the gates to enable her to drive into the Court: she is to be received at the door of the Lodge by Mrs. Philpott, who is to precede her upstairs walking backwards all the way into the drawing room."

J. always dearly loved a function and he must have regretted his absence from Cambridge at the Installation. On 6th July he wrote to his mother as follows:- 


\section{The Installation of $1847 \quad 63$}

"My Dearest Mummy,-I forgot to tell you in my last letter that Mrs. Okes ${ }^{1}$ was so kind as to send for me to breakfast with her on my birthday, as it was a whole holiday. After breakfast she took me and another boy who was breakfasting there also round the garden, and then brought us in and showed us some books of engravings and her cabinet of shells. She says I may go and see her whenever I like. My birthday, I assure you, was miserable enough away from home.

"I think you will have a splendid Installation; I only wish I was there to see it. 'I'he weather here is perfectly roasting; the evenings are beautiful. I often think of our happy summer evenings together, and wish I was at home, which in less than three weeks I shall be. Only think, we are to come back on the 4th of September, not quite six weeks.

"I get on very well with my swimming; I shall be able to pass in about a fortnight. . . . I long for your newspaper and account of the Installation.-Believe me, your affectionate little John Willis Clark."

Here is his mother's account of the function, dated 8th July 1847:-

" My DEAR LitTle Boy,-'The bustle is at length over and all has gone off well and satisfactorily. We have ordered a newspaper for you which you will get on Saturday afternoon.

"Monday.-Got up at six to cut roses, arranged about half in their respective places and put them in the cellar ; breakfasted, dressed, and joined Mr. Fisher's party at ten; from thence we went in a carriage to the Directors' gallery to see her Majesty arrive. 'There was an erection under the colonnade at the railway station. The royal carriages waited in front of us, and as the day was splendid the carriages were all open. The room through which we passed was covered with crimson cloth for her Majesty to pass through. The Mayor and Corporation received her

1 The wife of Richard Okes, at this time Lower Master of Eton, later Provost of King's. 
on the platform and preceded her to Trinity Lodge. There were two very handsome galleries on each side of the road close to the station and flags flying and lesser galleries in every direction. The Pensioners and Whittlesea Yeomanry came to meet her and also the Guards to clear the way. I forgot to mention that the High Sheriff in a full court-dress, Lord Hardwicke in uniform as LordLieutenant, and Lord Godolphin as High Steward were also in attendance. Papa went to the court of Trinity College to present the address. From the railway I went to the Senate House; about three o'clock Prince Albert arrived and was met at the door by the Vice-Chancellor, Beadles, \&c., and led to the platform where the ceremony of installing him took place; a short time after her Majesty arrived. The Prince went to meet her and conducted her to a chair prepared for the occasion; she was accompanied by the Duchess of Sutherland and Lady Desart. She looked very pleased; at six she dined in Catharine HallI arranged a bouquet for the show.

" Tuesday. - Went to the Senate House at nine, having previously despatched my plants; no one got in after eight; some were on the steps at five-hundreds were in the Senate House square where we enjoyed air at least. The Queen and Prince Albert were there to hear the Ode, ${ }^{1}$ \&c. At two we went to Downing where there were eight thousand persons. .... At six we went to dinner-this was very elegant and well managed. The ladies handsomely dressed, and everybody delighted. We assembled in the Combination Room and were taken to our places in the Hall by noblemen. I had a capital place. After we were all placed her Majesty and Suite came in; grace was said by the Master and Professor Sedgwick, and then we sat down to dinner. When the Royal Party left the Hall the ladies retired to Mr. Carus' rooms under the clock till nine, when we went to the Lodge for the Presentation. ... Very affectionately yours,

M. Clark."

Mrs. Clark's lively pen was equally capable of sketching the characters of her guests and of her hosts, and all for the benefit of her boy at school:-

1 Written for the occasion by William Wordsworth. 


\section{Cambriage Gossip}

20 th February 1850.

"We are alive, which you will be surprised at when I tell you of our dissipation. Mr. A- came on Saturday; Sunday, he and Papa dined at Caius; on Tuesday we dined at Emmanuel Lodge ; Wednesday, a party of thirteen at home; Thursday, dined at Trinity Lodge; Friday, a party of fourteen at home; Saturday, Mr. A- left us. Papa is quite worn-out, and said it seemed so different to our usual routine of every day alike!!!

"Mr. A- returns on Saturday for another week. Papa is very tired of him; he takes a great deal of room, knocks things over, spills the ink, spoils the pens, brings in a great deal of dirt, drops jelly and gravy on the tablecloth, and handles books so roughly that he dislocates the leaves ... he is also an eternal talker in a low voice, which requires all your attention. ...

"Papa would not let me go to the Bachelors' Ball ; but I hear it was a very good one, and there were no falls.

"Mrs. H- dined with us on Friday; her dress was so décolletée that we were quite shocked; her shoulders were out all the time, and when she moved I saw under her arm; it was white silk with a very thin black lace Pardessus over it. She must be a very strange kind of saint; I wonder if she has a tract on modesty. ..."

Beyond the meagre record that on 15th March, Johnny was "second in trials," I can find out little for 1850, except that Mrs. Clark, as usual, took several prizes at horticultural shows for her roses and other flowers. The family must have been at Eyemouth in August, because there and then she "sketched a rock resembling a peacock on one side and a judge on the other." They also visited Scotland.

Her description of the household of a friend with whom they stayed on their way to Guiseley would serve for the "argument" of a Jane Austen novel :-

28 th September 1848.

"I am glad to be able to tell you that we are once more at Guiseley, for though I believe the M-'s were 
glad to see us, I did not altogether enjoy my visittheir perpetual quarrels, his scolding his wife and children, and her indifference to everyone's comfort wearied me extremely. Then the perpetual going in and out of the room, the doors and windows open, and the making and altering of plans of amusement, with the children practising in the drawing-room all the morning, kept one in a perpetual fever.

"Papa is quite an old man, obstinate, cross and selfwilled.

"Mamma is much aged in appearance, her hair as grey as your grandmother's, still wearing no cap, and dressing in short sleeves and neck in the fashion of twenty years ago.

"Emma is a sweet girl, very quiet, sensible, fond of reading, desirous of information, but lamentably nearsighted; kind, amiable, and obliging.

"Mary is forward, pert, childish, idle, and Mamma's favourite.

"George is very short, a fine healthy idle boy. They have taken him away from the preparatory school in their own neighbourhood and are undecided as to where he is to go. Mamma hates all schools and wishes for a Curate who shall act as tutor; in the meantime the boy is ruined: he does as he likes and bullies Papa and Mamma, as indeed they all do."

As a further example of Mrs. Clark's troubles with her servants, I quote the following from a letter written from Cambridge, 28th October 1849 :-

"I am tolerable, but worried to death-the Cook turned restive on Tuesday and was worse on Wednesday, telling me that she should not attend to my orders-on Thursday she was dismissed. The Housemaid, who is to leave at the end of her month, pretends to do everything and neglects all-she is an impudent, violent, knock-about woman-you may always know where she is by the noise she makes. We had Peck's men from Wednesday to Friday, lime-washing the kitchens and larders, and a Charwoman to clean after them; to-day we have had Mrs. Kidd to cook a joint, and Papa cannot decide what to do about the Groom; if he stays his clothes must be ordered 


\section{Cambridge Gossip}

-he is most odious, will only do what his master desires, attends to no messages, and eats enormously!! Papa has been for a ride to-day to see whether he can clean a horse and turn one out well. I saw he was disgusted with the Groom going in to tea and leaving the horse untouched. Then there is a perpetual battle with $\mathrm{B}-$ : with all his horror at Dall not having propagated Verbenas, Heliotropes, etc., he has done likewise; and had the impudence to tell me to-day that it answered quite as well or better in February, just the time when Dall left. The grass is so long I dare not go upon it; and the apples having been allowed to fall off are rotting in the chamber. Our anemone-seed has not come up, for it has never been watered."

The following gossiping letter gives a curious account of the social life in the University in the middle of the last century :-

\section{5th May 1851.}

“. . . We have had rather a busy week. On Tuesday there was a Horticultural Show-nothing worth looking at. We afterwards dined at Emmanuel Lodge. On Wednesday the Ray - a very pleasant meeting - seventeen altogether, and they made a very good tea. On Thursday, we dined at Dr. Bond's-this was a 'triste affaire.' They had had many disappointments. Professor Maine was called to town-Mrs. Duffield was not well enough to come-Mr. Frere of Cottenham was taken very ill at his uncle's at Bury St. Edmunds of scarlet fever a few days before, and I am sorry to say died on Tuesday. This had distressed them very much. A few had been asked to come in in the evening, but John Parry was singing, and Mrs. C. Francis had a ball which interfered sadly. The room was very hot, and we were all very dull.

"On Friday we had a very small party at Christ's Lodge-Mrs. H - came out in silver-grey satin with black lace flounces and a white cap with marabout feathers!! The young ladies in pink silk. By the by, they are reckoning very much on his being knighted. $\mathrm{He}$ had the bad taste to say to Isabella Cumming the other day that he hoped it might be so, that his wife might go before the old woman at Trinity!!" 
J.'s letters home were those of a boy who had spent most of his time with older people, and this life with his elders was one of the causes which tended to isolate him from his schoolcompanions. Sixty-five years ago English boys matured earlier than they do now, and the following letters of J. to his mother seem to me to show some evidence of this :-

\section{8 th April 1847.}

"My clock goes very well and is very useful ; I keep the key in my desk for safety. I am very glad the enemy has been discomfited and that our sweet-scented China has got a prize. On Sunday we get up at eight and have to be down in the pupil-room at half-past, where Mr. Johnson explains to us the Epistle and Gospel and compares them with the Greek; when we have done this we go and breakfast, and at half-past ten go to Church, out of which we get at half-past twelve; at half-past one we dine, and go again to Church at three; we come out at four, and do what we like till tea-time at six, after which we have to answer the questions I enclose you on the Epistle and Gospel; at ten we have prayers, and then go to bed. ... .

"I like Eton neither better nor worse than when you saw me; I think perhaps I am not so much plagued as formerly. . . .

"The temporary Chapel is a most flimsy erection, and I think will soon fall. Several of the seats were broken last Sunday. The old one will be finished about October.

"I have been counting up the time to the holidays; we have thirteen weeks last Monday, or ninety days.

"I got into an awful scrape yesterday. I was out walking with another boy when we saw a gentleman at some distance. Not thinking he was a Master, we pursued our walk, but as soon as we got near him he stopped us, asked our names and told us to come to him at a quarter past six, which we did. He only gave us a long lecture and told us we ought to have 'shirked." "1

${ }^{1}$ If a boy meets a master, out of bounds, he is expected to go, quite formally, behind a tree or hedge. 


\section{His Letters from Eton}

J. does not often mention his schoolfellows, but in a letter written on returning to Eton for the autumn half in 1847 we learn some of their names. Mrs. Clark took her boy back to Eton at the beginning of the autumn term, and J.'s first letter to her shows he was settling down at the school:-

8th September 1847.

"After you left me I went in to seek Mr. Johnson, but I found he was out. Ward ${ }^{1}$ said that there was no absence and that I might come in almost when I liked. I gave Ward some fruit for him. I went to Mrs. Okes's afterwards and spent a very pleasant day there. ... .

“. . . I suppose Mrs. Welsh's poorliness arose from her grief at parting with me.

"Clarke, ${ }^{2}$ to my great delight, is messing with Gladstone, ${ }^{3}$ but I believe when Alderson ${ }^{4}$ comes back he will cease to do so. I gave him to understand that I did not mean to mess with him. At present I am messing with Crawford ${ }^{5}$ but I fear it is only temporary. Vivian ${ }^{6}$ has gone to his room on the other side of the house, but, not liking it, he has come back again and I am afraid he will not let me mess with him. On Sunday I refused to go down on my knees when Gladstone ordered me and endured several blows which I warded off. I have not known the least fear at any one.

"... Football has not yet begun; there were hardly half a dozen boys in the playing-fields. Mytton ${ }^{7}$ says it won't begin till the cold weather gets in. I will play most vigorously when it does."

During the summer of 1851 there was some discussion as to whether J. should remain for a fifth year at Eton or return

1 J. M. Ward, K.S., Fellow of King's College.

${ }^{2}$ Capt. H. L. W. Clarke, 23rd Fusiliers.

${ }^{3}$ Robert Gladstone, who became Chairman of the Mersey Docks and Harbour Board.

4 F. J. Alderson, son of E. H. Alderson, Baron of the Exchequer.

5 Oswald J. F. Crawford, C.M.G., Consul at Oporto, author.

${ }^{6}$ Probably Lt.-Col. Sir Arthur P. Vivian, K.C.B.

${ }^{7}$ Capt. D. H. Mytton of the 85th Regiment. 
to Cambridge and "coach" in mathematics and classics. On the 13th of July Dr. Clark wrote to him from Cambridge the following letter :-

"... It seems to me now that you are gaining with rapidity the advantages of Eton, and I feel as sorry as you can do that, according to our present plan, you are so soon to lose them. It is however not too late to reconsider this, and to contrast the only two ways in which I think you can profitably spend a year before coming to Cambridge. One way is to pass the whole or part of that year at Eton, with Mr. Johnson-the other is to reside with us, and have the best University Tutors I can procure, one in mathematics, the other in classics. If you are in Cambridge, you must resolve to have as little intercourse as possible with any undergraduates. For it has always been found an immense disadvantage and drawback to a man to have formed the habits of the University before belonging to it. For these habits, in such cases, are not the habits which pertain to study, but to amusements and those not of the most unexceptionable kind. Therefore it is to be considered how far you resolve on what may be painful to deny yourself, the pleasure of intercourse with those whom you may have been intimate with at Eton, and who are coming here next October. ... If you spend some part of the next year at Eton, you will have the great advantage of $\mathrm{Mr}$. Johnson's scholarship, when you can benefit from it at a much greater rate than you have hitherto done. But then, you must also attend the Mathematical Tutor there.

"It strikes me that, on considering these two different modes of passing the next year, and on comparing the benefits likely to arise from each as a preparation for College, you will incline to the Eton plan. I do not decide upon either, because I wish you to select that which you like best-not I hope for the pleasure and ease of it, but for the advantage. The advantage will, in a good degree, depend upon your liking any plan."

But J. had apparently already made up his mind, for on the 6 th of June, in describing a visit the Queen had made to 


\section{His Letters from Eton}

the College on the 4th, he says, "She has got us an extra week, wohich does not matter to me in the least," and he adds, "The Queen delighted the whole school by coming in a dress of Eton blue silk. It was certainly very thoughtful of her, but I hear she always does think of those things."

One or two more extracts from J.'s letters must bring to a close his Eton life :-

13 th June 1851.

"I have written to you thus out of my usual time to enquire whether or not you are going to the Horticultural Show on the 21st, because I want to come too, and I thought that it would be better to write early to settle it that there might be no confusion. I take it for granted that if we are in London we go to the Opera!!! Sutton $^{1}$ has been sending me such an account of the Fidelio that I am on the qui vive to hear it. I hope you will answer this by return of post and say whether you are going, because if you are not I should then find out whether there is opera on Monday the 23rd, because if there is I should like to accept Sutton's invitation of going with him, and here I should have to communicate with you again for a letter to get me leave. I add a letter to Dr. Hawtrey. You see I have specified that we mean to keep Sunday properly, but I dare say I shall be obliged to be back at Eton in time for morning Church, which will be quite easy as it is not till half-past ten."

Here is the added letter. One wonders if Dr. Hawtrey considered Westminster Abbey an equivalent for morning Chapel :-

"Mrs. Clark presents her Compliments to Dr. Hawtrey, and would be much obliged to him if he will give her son leave, from after two-o'clock school on Saturday the 21st till Sunday evening, to accompany her to the Horticultural Fête in the Regent's Park, and on Sunday to Westminster Abbey. Should Dr. H. object to giving her son leave for Sunday, Mrs. C. will take care he returns to Eton in time for morning service."

1 Probably the Venerable Robert Sutton, Archdeacon of Lewes. 
24th July 1851.

"Many thanks for your nice letter. . . I I have got twelve leaving books-very nice ones too. Mr. Johnson has given me Pensées de Pascal (the fourth copy we possess !) also De la Beche's Geological Observer, and Stanley's sermons.

"There was a most extraordinary animal exhibited here during the week of the Agricultural Show. They called it a Chinese pig, but I do not think it was one, I fancy it was something of the Coypu nature; it had a broad flat head, with the flesh hanging down on each side, a broad mouth something like a hippopotamus, and pinkish tusks that turned round into his gums again. On the back the skin lay on the flesh like that of any other animal, but underneath it hung down like a large bag to the ground, and also in a sort of frill round the legs. The shoulderblade felt like a piece of mill-board stuck on to the skin; you could pull it a little to each side, it was as hard as a board, his tail was like a pig's - he was almost three feet and a half long and proportionably tall; they said he had been five years in England, was in good health, but ate very sparingly. He seemed very happy, and quite tame." 1

The following undated letter gives a vivid picture of William Johnson :-

"This week has been considerably enlivened by a water-party that came off yesterday, when Mr. Johnson took all the fifth form in his house up to Marlow and back, a distance of 15 miles there; in all 30 . As in most parties by water it rained until 2 in the afternoon, so having started at 10 in the morning we were tolerably wet, but as we were rowing all the time and had had dry things sent up by the provision cart it did not much matter. We stopped to lunch at Clieveden, a place famous for beautiful woods overhanging the river. There we had immense fun, in finding a nest

1 Mr. R. Lydekker has kindly suggested to me that this amazing animal was probably a specimen of the Japan or Masked Pig, described and illustrated by Darwin in his Animals and Plants under Domestication, vol. i. pp. 72 and 73. 


\section{A Water-Party}

of stoats under a large heap of planks. It was a very curious sight when the planks were turned over to see the stoats' larder. There were quantities of young rabbits and a partridge's leg, besides débris in the shape of fur and skin, \&c. We, after a long chasse in which Mr. Johnson assisted most enthusiastically in dragging away the planks, succeeded in killing six large stoats, which we placed in a barrow that was lying there, and wrote a note which we stuck into a forked stick to say who and what we were and wherefore we had disturbed the planks. It had now become fair and we proceeded on our voyage. We wanted to reach Seymour Court, where a friend of Mr. Johnson's was to give us houseroom to dine in; we were directed to it, moored our boats, and walked about a mile inland to a grand house which proved the wrong one. We had to trudge back and man our boats again. I had pulled up to this point, but what with fasting, rowing, and walking I was so tired I lay down in the stern while one of the supernumeraries, one of which was to each boat, took my place. After another mile we reached our right Court, and were conveyed in flys up to it. We then put on dry things and sat down to dinner. I was that hungry I could have eaten Mr. Johnson himself; we had an excellent dinner, and about an hour after, i.e. about half-past seven, for we had not dined till six, started down again. By this time I was not the least tired and pulled all the way back easily. We reached Eton about eleven."

It is difficult to measure the progress J. made at Eton. Mr. Johnson writes to his father every half, but writes so diplomatically that it is not easy to see just what was going on. At the end of 1847 he says: "Your son has made on the whole what appears to me satisfactory progress during the schooltime, and Mr. Durnford gives a good account of him. ... I find him a very tractable pupil, and if he was in another house I should have nothing but pleasant intercourse with him. ... Though unwilling to make any general assertion, I feel myself bound to state that he is not treated with respect by his companions, and I think he is the worse 
for his school experience. Yet I am inclined to believe that he will in due time get more power to suppress what makes him at present so unlike the others."

The isolation of his childhood, and the fact that both parents spoiled him, largely accounts for his temper, which I take it is a shorter way of expressing Mr. Johnson's "what makes him so unlike the others." Still, apart from his temper, which was quick and at times passionate throughout his life, J. always was "unlike the others."

In April 1848 his tutor writes to Dr. Clark that he has "received from Mr. Carter a satisfactory report of your son's proceedings in his Division, though he has not shown power enough to reach the ordinary object of ambition, being 'sent up for good." He seems to have "learnt all his lessons and done all his exercises with uniform industry and with an encouraging amount of success." Mr. Johnson proceeds: "He has been in my room more than he used to be, of his own accord-this has been satisfactory," and concludes his letter by saying "that his social position in my house is more satisfactory than it was, and is likely to be still more so, as he and his companions get older." A year later (April 1849) he writes that in spite of J.'s great activity and eagerness to learn and improve, he does not maintain his early promise of scholarship and is deficient in grammatical accuracy. Still, in his desire to learn "he gives me a good deal more encouragement than other boys of harder heads. I think he makes more use of me than almost any pupil I have." This last sentence is significant.

Writing in March 1850, Mr. Johnson says: "I have been cheered at a time of general disappointment by a little prosperity in the recent important examination, in which your son made a greater start than anyone else and was very highly spoken of by Mr. Cookesley and by Dr. Hawtrey." Still, the tutor mistrusted J.'s power of keeping the place so won, and modestly thinks the fault may be his. At any rate his failure "to master the Greek and Latin idioms" 


\section{His Vale}

and his indifference to "the rules of Syntax" seemed to mark him out as one who would never be a pure Classic. Indeed, I think J. ever cared more for the matter than the manner of a book.

J.'s "Vale" on leaving Eton lies before me. It contains all the proper sentiments in the rather poor, self-conscious doggerel of one whose medium was never verse. It would be unfair to quote from it. He left at the end of the summer "school-time," 1851. 


\section{CHAPTER IV}

\section{FOREIGN TRAVEL AND COLLEGE LIFE}

From the time J. left Eton until he went into residence at Trinity College in October 1852, I gather that he was chiefly at home either in Cambridge or at Guiseley, and was very fully occupied in preparing for his entrance and other examinations. In July 1852 he started abroad with Mr. H. A. Holden (1822-96), who was bracketed Senior Classic in 1845 and was at the time of their tour Fellow and Assistant Tutor of Trinity. In 1853 Holden was appointed Vice-Principal of Cheltenham College, and five years later Headmaster of Queen Elizabeth's School, Ipswich. He was well known as a man of culture and an assiduous editor of the classics. Latterly he was a frequent visitor at the Athenæum, where he had many friends.

They first visited Paris, and later Switzerland and Bavaria, and returned down the Rhine. J. kept a very full diary of this trip, the first of a series of diaries which he always wrote, and often illustrated with clever little sketches, especially of architectural details, whenever he was abroad. This diary commences with his name surrounded by a calligraphic "setpiece" such as Mr. Hexter, the writing-master at Eton, would have rejoiced in. Below is the sentence, "Quid quoque die dixerim, audierim, egerim, commemoro vesperi" (Cicero, $D e$ Senectute). J. and his tutor began their tour by spending a few days at Paris, a city which J. always liked, and which, as far as I know, he now visited for the first time. It is prophetic that the first thing he did on the morning after his arrival was to visit the Bibliothèque Nationale, where Mr. Holden was intent on copying a manuscript. J. visited the sights of Paris very 


\section{Paris}

thoroughly, and thus laid the foundations of his accurate knowledge of the topography of that city.

Space does not permit more than a few quotations from the diary, but these few show the keen interest he took, not only in architecture and the life of towns, but in country scenery and in natural history :-

\section{Monday, 19 th July 1852.}

"Went in the morning to the Hotel des Invalides. Not much to see there, as the tomb of Napoleon, the chief object of interest, is not yet completed. Afterwards I visited the Chapelle Expiatoire built over the spot where Marie Antoinette and her husband were interred after their execution. The Swiss Guards are buried there still-a beautiful idea, I thought, to surround her, even in death, with those who had defended her so bravely while alive."

He and his tutor left Paris on the 20th by train for Dijon, and thence they started at four o'clock in the morning by diligence for Geneva :-

Wednesday, 21st July.

“. . . The whole country seems covered with flowers. I noticed Monkshood, Columbine, French-Willow, Blue Campanula, \&c., and myriads of butterflies, and when I say myriads it is no exaggeration, for the air in some places was quite thick with them. A splendid White Admiral flew past us. All of a sudden, turning round a corner sharp, the grand panorama opened out upon us. For a space of 200 miles wide we saw the Alps, with Mont Blanc in the middle; at their feet glittered the dark blue lake, and from that to the foot of the Jura lay a beautiful country, diversified with cornfields, villages, and woods. Such a sight I never could have dreamt of."

This view from the Col de la Faucille so impressed him that forty-two years later, when I was travelling with him in Eastern France in the late summer of 1894, we made great efforts to see it again. We spent two snowy nights and a day in a little auberge at the top of the Col, and certainly the 


\section{Foreign Travel and College Life}

glimpses I got between hurrying snowstorms of the view justified J.'s youthful enthusiasm.

From Geneva the party proceeded to walk round Mont Blanc, stopping at St. Gervais, Courmayeur, Aorta, and Châtillon; between this and Zermatt the adventure inevitable to all beginners in Alpine travel occurred :-

Tuesday and Wednesday, July 27th and 28th.

"Started from Châtillon at \%, up the Val Tournancheit is very beautiful at first, the road winding through a thick wood of Spanish chestnuts, almost up to the village of Antey. . . . At about half-past eleven we reached Tournanche, and dined in the house of the Curé. Engaged another guide there and proceeded to cross Mont Cervin to Zermatt. . . . When we had got a little way up the mountain it began to snow very fast, but both our guides assured us that it was of no consequence, and the one from Tournanche went up first, tried the glacier, and came back to tell us it was quite firm. Our muleteer here refused to go on, saying it would be the death of his mule; and, as it afterwards proved, it certainly would have been; at this point a more desolate and gloomy scene I never saw. We were standing on the moraine, with a plain of snow stretching round us apparently boundless; the only objects to be seen on it were some rocks to the left hand, and the snow kept falling faster and faster every minute.

" Notwithstanding, tying ourselves together with ropes, the guides carrying the baggage, on we went-for my part I was anxious to return, as I had read so much of the dangers of snowstorms, and thought it not courage but foolhardiness to proceed at such a time. However I was overruled, and on we went. Having passed along for some three-quarters of an hour skirting the rocks I mentioned before, our 'Tournanche guide began to stray about somewhat vaguely, and to take first one path and then another, till at length he cried out, 'Nous sommes perdus.' This was pleasant, and again I ventured to mention return, but our Chamounix guide said that this would now be impossible, as the snow by this time had obliterated our footsteps. He tried to keep up the Tournanche guide's spirits (but a more cowardly fellow no one was ever bored 


\section{A $\mathcal{N}$ ight in the Snow}

with) and reasoned with him about the direction he ought to take, but all to no purpose; it could not be found. He then told us that the best thing to do was to dig a hole in the snow and pass the night there. As Holden observed, it was very like digging our graves, and certainly I never expected to get through all the danger in the way we did. The cold was intense-my coat became like buckram, it was with the greatest difficulty that I could open my umbrella, and my fingers were so frozen that they would scarcely grasp my Alpenstock. Having made our hole, we stuck up our batons and fastened Holden's plaid to them, keeping it down at the bottom by piling snow on it. In a very short time the snow and sleet froze tight upon it, and it kept out the wind perfectly. We opened our three umbrellas in front, so that, except when a sudden gust came with unusual force, the cold wind was kept completely from us. I can in no way account for the cold I suffered all night long-I was between Holden and the guide, my feet were dry and warm, for by an excellent idea of Holden's we had taken off our boots and socks, and putting on dry ones, stuck them into our carpet bags; yet all night I shivered ceaselessly. At 3 the morning broke, but the snow and mist continued as bad as ever. At 5 our guide began to hunt for the road, leaving us in our auberge. The Tournanche coward was for returning to Breuil, and so was I, but he had passed the mountain some score times and should have known the road, which, when we did find it, was as plain as a pikestaff.

"Our Chamounix man kept begging us to wait un petit moment.

"Suddenly, as if by a miracle, up rose the veil of clouds, and disclosed to us the valley by which we had come the night before, and instantly closed again. About five minutes after they rose once more, and gave us a longer and more complete view, so that there was now not the least doubt about our way. At 8 we started, having been ten hours in the snow. 'The road was as easy as possible to find, and the snow perfectly hard. The glacier too was a very safe one just there, the ice being one smooth plain with only a few very large crevasses which, as we afterwards read in Murray, serve as sign-posts to mark the route, but our guide chose a short cut, which gave us 


\section{Foreign Travel and College Life}

a little trouble in one or two places, till at last we reached the moraine, and then all labour was at an end.... Zermatt was reached at 10 o'clock."

After a few days' rest they proceeded homeward by the Rhone Valley, Vevey, Berne, Zurich, Constance, Ulm, Stuttgart, Heidelberg, Frankfort, and down the Rhine.

J. returned to Cambridge for a week on 16th August, and then retired to Mr Holden's rectory at Brington, near Northampton, to read for his examination. Here he remained until the beginning of the October term, when he returned to enter into residence at Trinity. I extract a passage from his diary at Brington : although written in rather Family Herald style it expresses views on Greek which remained with him throughout his iife.

Saturday, August 28th.

". . Worked as usual at Xenophon, and really I cannot but think it quite monstrous that everyone is to waste four-and-twenty years of their life in learning two dead languages which can never be of the slightest use to them. They are years when all around wears its brightest and most joyous aspect, as seen through the magic glass of Youth; when life has as yet lost none of its freshness; its golden beauty is still untarnished, its opening flowers are unchilled by care-and these, these are to be wasted, utterly wasted, and at the end of them one is turned out ignorant of all that it is most useful to know. For to persons of moderate intellect it is labour sufficient to occupy their whole time to learn enough about Latin and Greek to satisfy their Examiners, and no opportunity is given of learning anything about their own country or any other that now exists. . .."

The Cambridge which J. came "up" to in 1852 was very familiar to him-he was born and bred there-but to us it would have seemed a different Cambridge to our Cambridge.

As J. has written, Market Hill was then encumbered with houses, and until the great fire of 1849 destroyed many of them a street called Warwick Street, or Pump Lane, ran across 


\section{Old Cambridge}

the eastern end of St. Mary's, and its western houses abutted on the fabric of the church. The central part of the Market Place was occupied by a block of houses facing four ways. The market-stalls occupied a comparatively exiguous area facing the Guildhall, an area further reduced by the fountain connected with Hobson's Conduit, then one of the chief sources of water-supply for the town. This was removed to the corner of the Lensfield and Trumpington Roads in 1855, when the present Company's water became available. Like the University Church, the eastern end of St. Edward's Church was cumbered with dwelling-houses and shops.

The existing Hall of Gonville and Caius College was built in 1854, but when J. came into residence the site of the most conspicuous of the present buildings of that College was occupied by a number of small houses running along Trinity Street and a little way down Senate House Passage. That nearest the Senate House was occupied by Macmillan \& Co. On the Trinity Street side of the College were two houses of interest; one, flanking the Gate of Humility, then and now occupied by the porter's lodge, had been the home of the first newspaper printed in Cambridge; the other, further down the street, was the Theatre Coffee-house. There was then a lane running down from St. John's Street to the Can, known as St. John's Lane. This and that curious congeries of college buildings known as the Labyrinth are ably described by Samuel Butler in his The Way of all Flesh. The Labyrinth, the chosen home of the Simeonites, was a relic of the infirmary of the Hospital founded about 1200 by a burgess of Cambridge, one Henry Frost. The Labyrinth and the Lane were both swept away when the present Chapel of St. John's was built in the late sixties.

On 20th February 1852, about six in the morning, a serious fire broke out in the first Court of Trinity Hall. Mr. R. Bowes tells me he remembers Dr. Whewell taking an active part in its extinction and being greatly concerned as to the possibility of its extending to the University Library, on the 


\section{Foreign Travel and College Life}

roof of which he directed that wet cloths should be placed. The façade of Trinity Hall as we now see it was "immediately afterwards rebuilt of stone, in a very neat and appropriate style, from the design of A. Salvin, esq." 1 Facing Clare Hall stood the ruined buildings of the old Court of King's College, now rebuilt and incorporated in the University Library.

The old buildings of Pembroke still stood, and were not replaced by Waterhouse's structures until 1875 .

A few years before J. came into residence the Botanic Garden had been removed from the site of the old "public physic garden" in the parishes of St. Edward and St. Benedict -part of the site was a portion of the dissolved Priory of St. Augustine, where the "New Museums" now stand. The last relic of the "physic garden" is a splendid specimen of the Sophora chinensis, which yields the dye for the imperial yellow Court clothing of the Chinese, and which in summer somewhat darkens the windows of the Pathological Laboratory. The building of the Fitzwilliam Museum was then incomplete. The massive and forbidding gaol stood, as J.'s mother mentioned, on the south side of Parker's Piece where Queen Anne's Terrace now stands. The "handsome and commodious shirehouse" on Castle Hill had been erected in 1842, and had involved the destruction of the romantic gate-house of the old castle, a piece of vandalism but too typical of Early Victorian methods.

In those days there were no public parks. Horsemen cantered over Parker's Piece, or undergraduates played football there "without uniform or regular organisation," and for many years afterwards Christ's Piece, enclosed by a rough fence, was used for grazing sheep. Jesus College owned the Lammas rights.

The Corn Exchange was not built, and Corn Exchange Street, then called Slaughter House Lane, was flanked on the western side by rows of slaughter-houses, whose site is now occupied by the Exchange, the Anatomical and Physiological Schools, and by part of the Medical School.

1 Cooper's Memorials, i. p. 133. 


\section{Trinity College}

Boating in the early fifties was greatly hampered by the strings of barges proceeding along the narrow river course. After passing Midsummer Common, the horse was cast off and the barges were punted past the backs of the Colleges by stout poles called "spreads" to discharge their cargoes at the hythes between Magdalene Bridge and St. John's College, or more usually in the Mill Pool above Queens'. The bargee, too, was still a social factor, as readers of 'Thackeray's "Codlingsby " will remember. Within the last few years, punting has been resumed on "the backs" not with the happiest results,_-" quieta non movere" applies very literally to the bottom of the Cam.

Even in the seventies Cambridge would have seemed odd to our eyes. The earlier fashions lingered, I believe, longer at St. John's than in other Colleges. There cap and gown were compulsory until 11 A.M., and the lectures began at 8 o'clock in the morning. Some of the Dons had very marked individualities, and held very strong opinions which they did not hesitate to express. One of these gentlemen who married late in life, returning to his church after a honeymoon of six weeks, publicly thanked God "for three weeks of unalloyed connubial bliss." The same gentleman once defined his religious and political position in these words: "I, sir, am a HighChurchman and a Tory, and I fail to see how a gentleman and a Christian could be anything else." There are still left those who heard and remember a sermon of his in the College Chapel; when passionately declaiming, "The centuries ask us, What is Faith?" he startled his hearers by thundering out, "But, the answer is No." He once rebuked a Junior Fellow, who was smoking a pipe in the Wilderness, with the remark, "No Christian gentleman smokes a pipe, or if he does he smokes a cigar."

J. came up to Trinity in 1852, and thus began his association with the College which lasted for nearly sixty years. He was always very proud of his connexion with Trinity, and, though on occasions he would say a bitter word with regard to some action of the College Council, he would be the first to defend his 


\section{Foreign Travel and College Life}

College from the attacks of others. In 1903, by way of making some return for what he felt he owed to Trinity, he presented the College with a copy (purchased in Spain) of Antonio Moro's well-known portrait of Queen Mary. Of this picture J. used characteristically to remark that it proved that, whatever other failings Philip of Spain had, he was at any rate a gentleman: for after seeing the original picture (which was specially painted for him) he still married the lady!

1852 was also the year of the publication of the "Report of the Commissioners for Inquiring into the State, Discipline, and Revenues of the University and Colleges of Cambridge." Until the new Statutes, which were adopted as the result of this inquiry, were promulgated, there had been little or no change at any of the Colleges since the time of the original Statutes drawn up by the Founders. At Christ's College, Lady Margaret's Statutes governed us for 350 years. But the publication of the Report just mentioned marked the end of the old University and College life and the beginning of the modern academic Cambridge. With this beginning, "enter J."

He came into residence in October. It was a spacious and a leisurely age, and apparently one did not at that time look very far ahead. Only on the 9th October did his father "go to Mr. Cooper in the morning, and found that I could have rooms." Two days later J. "went down early to Mr. Cooper, and talked some time with him. After luncheon, went with Mamma and Papa to my rooms and arranged what was wanted. Then went to shops and sent things in."

"My rooms" during the next four years were H.6, New Court. On taking his degree he moved to D.4, in Nevile's Court, and two years later to D.5. When living in D.4, he had in the rooms opposite one who remained his friend throughout life-Charles Gray, now Rector of West Retford. These sets of rooms were over those occupied by Mr. W. G. Clark, the Shakespeare scholar, and of Mr. Martin, the Bursar. Even as late as $1870 \mathrm{~J}$. had rooms in College, R.7 Great Court, and these he occupied, although he had ceased to be a Fellow, 


\section{F.'s Tutors}

in virtue of the fact that he was working at the College muniments.

J.'s first Tutor was John Cooper, 33rd Wrangler and 7th in Class I of the Classical Tripos of 1835. He gained his Fellowship in 183\%. Cooper left Cambridge in October 1855, and two years after $J$. took his degree was instituted into the College living of Kendal, and became Canon of Carlisle and Archdeacon of Westmoreland. He appears to have been an amiable, right-minded man, of no particular force. In those days, however, Tutors of Colleges had few dealings with their pupils beyond sending in their terminal College bill. In that matter I gather they were precise.

The following extract from Professor James Stuart's admirable account of Cambridge as he found it in 1862, shows us that the Tutor of fifty years ago thought it no part of his duty to inform a candidate for a scholarship of the result of his examination. "After having sat for that, and before the result was known, I went to Harrow to pay a visit to my uncle, James Stuart. Being somewhat of an Evangelical Churchman, he took in the Record, and about a week after I saw in it, accidentally, a notice of the names of those who had gained the minor scholarships, including my own. The incident, I think, shows the rather slipshod method in which college tutors then conducted their business. I wrote to Mr. W. G. Clark, my college tutor, saying I had noticed my name in a list given in the Record of such and such a date, and asking him if it were correct. $\mathrm{He}$ wrote back a very short letter, consisting of the following words: 'My dear sir, the Record has in this instance spoken the truth.' I afterwards learned that he was not of the Evangelical persuasion, and read the Guardian." 1

It was a Trinity tutor, somewhat senior to Mr. Cooper, who, having told his servant to ask one of his pupils to wine, and being reminded by that functionary that the gentleman in question was dead, replied in a voice of thunder, "You ought to tell me when my pupils die."

1 Reminiscences, by James Stuart, pp. 144-5. 


\section{Foreign Travel and College Life}

From $1850 \mathrm{William}$ Collings Mathison had been associated with Mr. Cooper in the direction of his "side," and when Cooper left in 1855 he became solely responsible for it, and J.'s later bills are made out in his name. He was an accomplished musician, and, to those whom he liked, generous and kind; but there were others, and on the whole I do not gather that the junior members of Trinity suffered much when he married and retired to a college living in Norfolk. There he presently died. Tom Taylor lived in the rooms above Mr. Mathison's if I am right in identifying the latter as "the small precise Don "; and he it was, according to Bristed, who used to put mice into the Tutor's milk jug. ${ }^{1}$

We have seen that J. was not altogether a happy schoolboy, and that he did not derive all the benefit he might from Eton. When he came up to the University, however, things were different. He was lucky enough to get into a remarkably nice reading set, and I gather he thoroughly enjoyed his undergraduate days. It is only sixty years ago, yet almost the only member of this set whose name $I$ have been able to retrieve is William Court Gully, afterwards Speaker of the House of Commons, who took his degree in 1856.

J. soon learnt that his father, who always had a high opinion of his boy's ability, had set his heart on his getting a Fellowship. J. himself thought he had no possible chance; but he worked hard, "probably as hard as ever man did," and, thanks to the aid of Lightfoot and Lemprière Hammond (the latter of whom, J. said, "made me"), he obtained a first class in the Tripos.

J. has drawn for us the day's work of a reading man when he was "up," and we can safely assume that it is a sketch of a day in his own student life. He took, I believe, little part in formal athletics; but, as his mother wished, he rode regularly, and, as was the habit of the age, took long walks. On wet afternoons the members of the University "resorted to the cloister in Nevile's Court, Trinity, which from two to four

1 C. A. Bristed, Five Years in an English University (New York, 1852). 


\section{France and Germany}

o'clock would be quite thronged with pairs of dons and undergraduates pacing backwards and forwards." 1

One echo of the time, which shows his established love of play-acting, has come down to me. Then, as now, societies existed for the weekly reading of Shakespeare's plays. Some one once told me that the first time he saw J. was on entering a room where one of these gatherings was soon to begin. J., who had apparently been allotted the rôles of one or two "walking gentlemen," was bitterly exclaiming, "I wonder what fool has cast me for these parts!" In fact, if J. had the gift of light verse-and this he had not-he might have said with Calverley, who occupied the other end from J. of Class I in the Classical Tripos of 1856:-

\footnotetext{
"When within my veins the blood ran, And the curls were on my brow,

I did, oh ye undergraduates,

Much as you are doing now."
}

In 1853 he went abroad with his parents, and, after a day or two at Paris, made an extensive tour in Germany. As usual when abroad, he kept a very detailed diary, and some excerpts from this are here appended:-

"Tuesday, June 21.-Went after breakfast to the Mint, which was somewhat disappointing, except the stamping of the coins, which interested me much. Then to Notre Dame to see the Funeral of the Pope's Nuncio. The Cathedral was hung with black, and the choir and the portion under the centre carpeted with the same. At the intersection of the Nave and Transepts an immense Catafalque had been raised, with Statues at each corner, and with a hundred lighted Tapers and three great candelabra. . . . 'The black hangings were then drawn aside, and showed another candelabrum behind lighted. From the Catafalque to the choir was a line of priests on each side and some soldiers in front of them. There seemed about 300 priests

1 "A Septuagenarian's Recollections of St. John's," The Eagle, $\mathbf{x x x}$., 1909, pp. 16, 17. 


\section{Foreign Travel and College Life}

altogether. 'The Archbishop officiated in a black cope embroidered with silver, and wore his mitre. The music was most impressive, and one part of the service especially so, viz. when the Host was raised the whole congregation fell on their knees, including the soldiers, and they played a rappel on their drums."

"1853, July 5, Dresden.-Which is right, Rome or the English Church? All seems so unreal, so unsatisfactory. A sort of pageant-a troop of actors professing certain ideas-and day after day repeating what they have been told to say-while the world goes on in its sin and its misery, getting neither better nor worse, except in the cases of a few rare men, who seem to have solved the problem of Life, and to understand why they are here. There's the rub. What is my vocation here? How am I to employ myself usefully?"

"Wednesday, July 6th.-Worked at Agamemnon till one. . . . Went into the Catholic cemetery. It is the most charming place I ever saw. The gravestones are nearly all plain crosses, and the whole plot is thickly planted with roses, which grow in wild luxuriance about, and yet seem cared for and carefully cultivated. . . . Went afterwards into the Lutheran cemetery ; it is just like the Catholic one, only not so thickly planted with flowers, and does not look such a holy place. And then I like the large crucifix so -looking over the whole graveyard; emblem of how Christ watches over the faithful departed till they rise again."

"Friday, July 8th.-At six there was a short but severe thunderstorm, with very vivid lightning. When it was over, walked . . . in the common near Friedrichstadt. I never heard anything like the frogs-they had the true Athenian croak-I could really at times distinguish the $\beta \rho \epsilon \kappa \epsilon \kappa \epsilon \xi$ quite loud, and the $\chi \circ \alpha \xi$ very often."

"Friday, July 29th.-Went to the Opera to see The Huguenots. I never remember to have seen in a theatre any piece that gave me so much pleasure. In scenery, music, acting, and dramatic power it surpasses everything I have before witnessed, and quite comes up to my ideal of an Opera."

“Tuesday, August 2nd.--Went to hear Lucrezia Borgia. It was grander than I had expected, tho' I heard so much in its praise from Sutton. The actress who took the part 


\section{Germany}

of Lucrezia acted and sang extremely well. One scene particularly struck me. When Orsino sings the drinking song, all of a sudden the sounds of the Mass for the dead are heard. The lights are all extinguished, and the guests cry out in horror, 'Who has done this?' All of a sudden the doors at the back of the stage are thrown open, and in the doorway is seen standing Lucrezia, pale as death, in a long black dress, with not a bit of white to break its solemnity, and a servant on each side holds up a light. In answer to their question, she answers triumphantly, 'I, Lucrezia Borgia!' I never saw such magnificent acting."

"Blankenburg, Tuesday, Sept. 26th.-Went in the morning to see the ducal Schloss: it contains a lot of ugly pictures ... a good deal of ordinary furniture, and other usual appurtenances of a country gentleman's house. The best thing there is the collection of stuffed birds and animals, which are worth going to see alone; I never saw such expression given to stuffed creatures: they were done by Mans of Brunswick. Wild cats are still shot in the Harz: two are preserved there which the Duke shot near."

"Wednesday, Sept. 27th.-Went by rail from Magdeburg to Leipsic, as _ was anxious to see the annual fair, now going on there.

"I did not see such a variety of costumes as I had expected. One Armenian passed us, and there were a good many Tyrolese, one of whom was very friendly to us, and saluted us with 'meine Liebe.' In the evening went to the theatre, where they performed Czar und Zimmerman. It was well enough, better than I had expected."

In the following year (1854) "Johnny went in for a Trinity scholarship," but was unsuccessful. He came out fifth in his year in the annual examination at Trinity, but was only awarded a Second Class. On 24th June he came of age. In February 1855 "Johnny declaimed in Latin in the Trinity College Chapel," and on 20th April he was elected a Scholar of his College.

J. took his degree in 1856, bracketed last in Class I of 


\section{Foreign Travel and College Life}

the Classical Tripos. Brown of Trinity was Senior, Calverley of Christ's second, Horton-Smith ${ }^{1}$ of St. John's bracketed fourth. The previous year Montagu Butler of 'Trinity had been Senior Classic, and in the following year, 185\%, Moule of Corpus, Seeley of Christ's, F. 'T. Platt of Trinity, and Snow (later Kynaston) of St. John's were all bracketed Senior, while in 1856 Fawcett of 'Irinity Hall had been seventh Wrangler, and Bonney of St. John's was bracketed twelfth.

In the Long Vacation after taking his degree J. travelled in Norway and Sweden in company with J. W. Dunning. They wrote an account of this tour, which was printed, without the authors' names, in 1857.

J. was in Cambridge most of $185 \%$, though the early part of the Long Vacation was spent in a short tour in France. The Long Vacation must have been different then, for in what is now the deadest time of the academic year, when only the plumber and the paper-hanger prevail in College, the University was peopled with Dons and undergraduates:-

"Wednesday, Sept. 23rd, 1857.-Wrote to mamma and to papa. Called on Mrs. Pryme. She told me some curious stories about old Cambridge. The Duke of Gloucester was here for some years, and used to go out to tea, like the rest of the world, with his tutor; among other places he went one Sunday to Jesus Lodge, where after tea they played at blindman's buff, in the course of which he kissed Mrs. Beadon : ${ }^{2}$ which kiss procured her husband a Bishopric. But this story is apocryphal, as the Duke probably never had influence enough to procure anyone a Bishopric. When he came again here, as Prince William, his old friends called on him at Trinity Lodge; among others old Mrs. Thackeray went with two of her young children, Mrs. Pryme, and one of her brothers. The children were told to walk in the court till mamma came down. The Duke received her very graciously, and asked after her children. "Oh, they are below," said she, and pointed to them through the

1 Now Treasurer of Lincoln's Inn.

2 Wife of Richard Beadon, Master 1781-1789. 


\section{Fellow of Trinity}

window. There was some plum cake on the table, and the Duke took two pieces, wrapped them in paper, and gave them to her for the children, who were, of course, mightily pleased with the present, and cherished the fragments of cake and the paper till they fell to pieces from age."

Of the thirteen men who appeared in Class I of the Classical Tripos of 1856, twelve were elected to Fellowships, and three of the second Class had a similar success. In those days the University was small, the avenues to Honour degrees but four, and when two years later E. C. Clark, now Regius Professor of Law and the Senior Classic of 1858, was not elected to a Trinity Fellowship-(he was elected the next year)-there was a good deal of comment. Never having lived in an old ladies' almshouse, I cannot estimate the extent or the range of their gossip, but I doubt if in intensity and minuteness it surpassed that of the Combination Rooms before 1881, when, by the merciful intervention of Parliament, dons were allowed to marry. J. himself always said, "I never ought to have got a Fellowship, but there happened to be eight vacant that year, and they gave me one." To the dons of those days it was a problem, and a much discussed problem, why the last of the First Class of the Classical 'Tripos of 1856 received a Fellowship in 1858, one year before the Senior Classic of 1858. "It's the metapheesics that did it," as old Francis France of St. John's explained, showing a humorous contempt both for the Papers on Moral Science which Dr. Whewell had introduced into the examination for Trinity Fellowships, and a sound appreciation of J.'s fundamental and whole-hearted incapacity for any kind of Mental Philosophy.

Whilst he was an undergraduate $\mathbf{J}$. was not extravagant; three of his College bills lie before me, and the terminal average is about $£ 33$. Of course there was Scroope House to fall back upon for hospitality to his friends and himself, but J. was, when I knew him, ever careful of money. Often he was generous, often he spent considerable sums on what 


\section{Foreign Travel and College Life}

seemed to him worth expenditure, and even those who knew him intimately would have been surprised had they known of the sums he lent to friends, in all walks of life, who found themselves in financial difficulties. He was accustomed to say with pretended cynicism, "Never spend any money," but more than most men he carried out the injunction not to let his right hand know what his left hand did.

We now come to a time when our material fails us. Whilst an undergraduate, J.'s home was less than a mile from his rooms; thus there were no letters to his father or mother, or hardly any that remain. Few of his intimate friends survive, and although such as I have been able to get in touch with have done their very best to help, I have gleaned but little. 


\section{CHAP'TER V}

\section{J. AS A BACHELOR}

J. has recorded that after his steady and strenuous work for his degree, and then for his Fellowship, "for the first time in my life I discovered that there was such a thing as amusement," and he amused himself. His father allowed him a liberal income, although I gather that J. thought it inadequate. He hunted, he danced, he dined, and was the cause of the dining of others; he took an active part in many of the social clubs of Cambridge and especially in the A.D.C. He had a certain skill in sketching, and thought he should like to be an artist; he knew-for the period-a good deal about anatomy, and, I have been told, would like to have succeeded his father in his Chair; "I planned this and I planned thatamongst other things an edition of Aristotle's De Partibus Animalium," but nothing came of it all. He regretted that he had not qualified as a doctor, but as a potential patient I am glad he did not. He worked hard at French, which he had first learnt as a child at Boulogne, and which he always alluded to as the "native language." He spoke it with ease and pleasure.

At the instigation of his friend, Dr. Luard, he at this time began to collect the long series of tracts recording Dr. Richard Bentley's quarrels with 'Trinity. This developed; and he soon found himself collecting Cambridge literature of all periods and upon every subject, with the result that by the end of his life he had brought together a unique local collection. This collection he bequeathed to the University.

J. liked travelling, but never ventured very far afield. $\mathrm{He}$ liked moving about in the Latin countries, especially in France, which he always spoke of as "La Patrie" or "Le sol sacré." 
He was fond of making in French what on the stage are called "asides," and he affected to believe that no one except the person for whose benefit the "aside" was made understood him. Sometimes he used to excuse his sudden burst into French by adding, "Je dis quelquefois des choses étranges." Perhaps it was as a result of this that Mrs. J. used to declare that the parlourmaid at Scroope House had purchased a French dictionary, so as to be able to follow J.'s table-talk. Certain it is that on one occasion he was somewhat taken aback by a Cambridge cabman, whom he had just engaged, saying that he thought it was only fair to tell him at the beginning of their drive that he understood the French language!

He was less happy in Northern Germany, particularly after 1870 , and thenceforth he classed all Germans as "plunderers from Prussia"; but for him Vienna and Munich were by no means places to be passed by. The year he was elected to his Fellowship he spent largely abroad, visiting France and Italy in the winter of 1858-59. I reproduce one of his letters written to his mother in the spring of the latter year:-

\section{NAPLes, Saturday, 12 th March 1859.}

"Spent the whole day in ascending Vesuvius. Before starting I had just time to go to the Church of the Incoronata to see Giotto's frescoes. They more than come up to my idea of his beauties.

"Left the Inn at 11 A.M., drove to the Hermitage, or rather as far as the lava would allow us, and then crossed the lava on foot. It was so hot in places that we had to make detours to avoid it.

"The ascent of the cone is most fatiguing-you have to clamber up loose cinders, which give way perpetually. This lasts for some 40 mins., and then you reach a tolerably level plain of sulphur, on which are the two craters of 1849 and 1858, the latter by far the larger. Both emit smoke. Occasionally we heard a noise like thunder, proceding from the fall of huge masses of rock into the crater. Beyond this plain rises the actual summit, a low pyramid, from which the descent is a sheer precipice on the side towards Pompeii. On the other it descends to 
the old crater, now filled up-which was active before these two later ones were opened. The descent was very rapid down the steep slope of ashes. We spent some time in watching the lava as night closed in. It caught a young tree, whose root was speedily burnt through, and down it fell into the burning torrent, which was falling down so steep a slope as to look very much like a fiery cascade."

J.'s regular diary dates from 1860 , and by this time he must have become Tutor to Lord Milton, eldest son of the sixth Earl Fitzwilliam, and father of the present Earl, for on the third day of the new year we find him returning from Wentworth to Cambridge. It was at Wentworth that he developed his taste for hunting. 'The entries are short and for the most part trivial : "rode with W.," "hunted with the X. hounds," "went to the Y. Ball," or "dined with the Z.'s." The first really serious record is on "Thursday, 23rd February.-Congregation: Sermons at St. Mary's on Sunday mornings abolished." The following month he read his first paper-one before the Cambridge Architectural Society-on the "Annals of All Saints' Church," 1 and in March he lectured before the same Society on "The Roman Catacombs." His interest in architecture and archæology was already keen, and he was taking an active part on the Committee then occupied with the restoration of the Octagon at Ely Cathedral. Part of June was spent yachting off the south coast with the Fitzwilliams, and in August, accompanied by Lord Milton, he started for a trip to the Faroes and Iceland. A somewhat arid account of this journey was published in 1861, in a volume entitled Vacation Tourists and Notes of Travel in 1860, edited by Mr. Francis Galton.

Late in the autumn he was back at home, and the usual short entries for the ensuing winter in his diary are confined to recording where he dined or danced, or with what pack he hunted; still he was occasionally working at the Museum; for instance, the entry for 18 January 1861, is "At the Museum. 
Prince of Wales ${ }^{1}$ arrived 3 P.M." Six days later J. dined at Magdalene, to meet Charles Kingsley, who had been made Regius Professor of History, an appointment not entirely unconnected with the Prince's residence at the University. Part of this year he spent in an extended tour in Switzerland and Italy. Lord Milton accompanied him, and for part of the time J.'s friend, David Powell, who was on a sketching tour in Italy, joined the party. J. was very intimate with all the Powell family. David was now up at Trinity; and later on when Henry came into residence (1864-1868) J. looked after him as if he had been his own younger brother.

The following describes an episode common enough in the early sixties, but none the less unpleasant:-

La Spezzia, 10th September 1861.

"Now I must tell you my adventure. Between here and Sestri you must know that the road leaves the coast, by reason of certain inaccessible cliffs, and strikes inland across a lofty Pass. From the top of this a road goes to a place on the coast called Levanto, and thence a path leads to another village called Monterosso, at both of which there are very ancient and curious Churches. From Monterosso a path leads into the highroad again, about 3 miles from here. So I left Powell at the top to go on to Spezzia, went to my villages, saw the Churches and the people, who were not the least curious part of the sight, and got into the road again between 6 and $\gamma$ in the evening. Having gone along it for a mile or so, I came to a village, when a Brigadiere, a sort of superior policeman, who is captain of the parties of Carabinieri stationed all about the country, came forward and asked for my passport. It is needless to say that, after all the Italians have said officially about the needlessness of passports, and having never been asked for mine since I came into Italy, I had sent it on with the luggage. I suppose he thought me a suspicious person, for he would not take my word that I was an Englishman, but made me come with him to the barrack-room, where he wrote a note to the Mayor to ask what to do with me.

1 King Edward VII, who spent the year 1861 at Cambridge, living at Madingley Hall. 


\section{A $\mathcal{N}$ ight in Prison}

I demanded to see the Mayor, and telling him, as we walked along, that he had better mind what he was about, he got so angry that he took me back at once, and put me in a filthy cell, pitch dark, where some deserters had been lodged. Presently back came the answer from the Mayor, that "for greater security" I had better be detained. Then I asked to be allowed to send a messenger to Spezzia for the passport, but this he refused to allow. I got leave, however, to send for it very early in the morning. Then I begged for a cleaner. room, and finally got changed into one where I had two tame rabbits for companions. Being duly locked and barred in, I was left for the night. The soldiers were extremely kind, and gave me fruit, and a pillow which they shoved through the bars. About 7 A.M. Powell and the passport came. He, it appeared, had not even been asked for his, so then I flew at the fellow, and gave him my mind. On getting to Spezzia I went at once to the Consul, who is Lever the Novelist; he has taken the matter up warmly. By great good-luck Sir James Hudson, our Ambassador at Turin, is coming here in a day or two, and, by threatening to lay the matter before him, Lever has frightened the authorities into vigour. I shall know more before I write again as to what will be done. Probably a good deal, as the Italians just now know how important it is to be civil to the English. Now that we have seventeen ships of the line at Naples, we are not people to be rashly put in prison with tame rabbits."

A fortnight later J. was writing to his mother that Lord Fitzwilliam had suggested that he should accompany Lord Milton to the United States. J. gives his reasons for declining the offer, and amongst them is that-

"I have so much work to do before the British Association meets in September that, even supposing I did go, I could only stay three months. Furthermore, I said I could give no answer till I had talked to Papa about it. I own it would be great to visit America, now that they are at sixes and sevens-immense fun-but I can agree to no plan that will prevent my having our Museum in first-rate order by September."

It is just as well J. remained this side of the Atlantic. 
He would not have liked the United States, and he would have said so. As it was, he busied himself with parochial affairs in Cambridge.

A perennial source of complaint amongst the members of any College is dinner-either the quality or the hour is perpetually under discussion and the subject of petitions to the powers that control such matters. In 1862 there was a successful agitation at Trinity to place the hour of dinner (then at 4 P.M.) later, and J. wrote a reasoned and moderate pamphlet in support of the change. Since it reveals a state of things very different from that obtaining at present, I quote a couple of paragraphs:-

"For a majority of Undergraduates, the morning is terminated by a Professor's lecture. Attendance upon these is necessary for those who intend to take Holy Orders, as well as Candidates for the ordinary B.A. Degree. 'These lectures are all given at a comparatively late hour, and necessarily so, to suit the College Lectures and the arrangements of Private Tutors. 'To take the Lent 'Term of 1862 alone, I find the following hours set down in the Schedule:

The Regius Professor of Divinity. 1 P.M.

The Professor of Chemistry. 2 P.M.

The Plumian Professor of Astronomy. $1 \frac{1}{2}$ P.M.

The Professor of Anatomy. $1 \frac{1}{4}$ P.M.

The Lowndean Professor of Astronomy. 1 $1 \frac{1}{4}$ P.M.

The Professor of Mineralogy. 2 P.M.

The Disney Professor of Archæology. 1 P.м.

"Of these the Professors of Divinity, Anatomy, and Archæology finish their lectures about 2.15 P.M. : those of Chemistry, Astronomy, and Mineralogy, between 3 and 3.15 P.M.: so that those Undergraduates who attend the former, get about an hour and three-quarters for exercise; those who attend the latter, from one hour to threequarters of an hour."

The following year J. stayed in England, but made long excursions in the Lakes, and in Wales and the West Country, sketching and collecting plants. But he was now becoming more 


\section{Work in London}

serious : he notes in his diary that Dr. Luard, his predecessor in the office of Registrary, "had 396 votes, whereas his opponent Mr. Power had but 253"; he records on the 20th January 1863, "Dr. Humphry's lectures began," which is probably a hint that his father's health was beginning to fail. J. was now beginning to look about him for something definite to do, and in September of 1863 he obtained the offer of a post at a salary of $£ 350$ a year, as General Managing Editor in the establishment of Messrs. Cassell, Petter, \& Galpin, the wellknown publishers. About this time he was spending a good deal of time in London, living with his great friend Frank Campbell, brother of the present Mrs. Pemberton of Trumpington, and was doubtless writing for his firm. He brought out an edition of Robinson Crusoe, and, in collaboration with Canon Teignmouth Shore, an edition of Don Quixote, but on all this the diaries are, and J. was himself, as silent as the grave. Those few friends who recollect the time have a misty notion that $J$. was not happy in the business of publishing, and he did not endure it long, resigning in the early spring of 1865 . A near relative, however, tells me that he was really interested in his London work, and often told Mrs. J. that though he gave it up from a sense of duty to his father, it was a great sacrifice at the time, and one that he was long in getting over.

As was proper to his temperament and his time of life, J. was now from time to time falling in love, and then scrambling out again. Into these affairs we need not enter, but the first indication of his friendship with the family into which he ultimately so happily married occurs in the diary for the year 1864-an unusually meagre journal, wherein fourteen entries suffice for the whole year. During the spring of this year he visited Germany, and, after staying at Leipzig and Dresden, reached Berlin on April 1st, "saw Buchanan," 1 and

1 This, I gather, was Edward Buchanan, for whom he had formed a strong undergraduate friendship, and who died in 1870. After him J.'s elder son was named. Edward Buchanan's father was then our Ambassador at Berlin. 
the next two or three days he dined at the Embassy every night.

During this year Great St. Mary's Church was re-seated, and as the change was considerable, and $J$. was mueh interested in it, I quote his account of the abolition of the Doctors' Gallery :-

"'This wonderful gallery, officially termed 'the Throne' or 'the Doctors' Gallery,' but by a rather profane, and very silly, pun, always spoken of familiarly as Golgotha, was a large room. It occupied the whole width, and about half the length, of the chancel, and was fitted with seats rising in tiers one above the other. The back was formed of large panels of oak. The Vice-Chancellor sat in a capacious arm-chair in the centre of the front row. It should be mentioned that the tower-arch also was blocked by the organ, which had a gallery in front of it. This latter affected to be of stone, and in the Gothic style, but was really of plaster. When a popular preacher occupied the pulpit, and the church was quite full, it must be admitted that the effect was good, and members of the University could see and hear exceedingly well. But those who had planned the arrangement had forgotten, or did not care to remember, that a church is built for other purposes than to hear sermons in, and Archdeacon Hare did not speak too strongly when he called St. Mary's 'an example of the world turned topsy-turvy.' However, when the late energetic Vicar, the Rev. H. R. Luard, undertook to get 'Golgotha' and its accompaniments removed, he encountered much vexatious opposition from all parties interested in the church. The old difficulties in obtaining funds were renewed. It took ten years to get $£ 3300$ together; and the present excellent and decorous arrangements were not completed until 1864."

Professor Clark had been failing in health for some time, and in November 1865 he resigned the Professorship of Anatomy. He was succeeded early in the following year by Dr. (later Sir George Murray) Humphry on the Human Anatomy side, and by Alfred Newton on the Zoological side. J. was then 
(1866) formally appointed Superintendent of the Museum of Comparative Anatomy, which, as he tells the Electoral Roll in his letter of application, "has been under my charge ... for the last four years." He was also appointed at the same time a member of the newly-formed Museums and Lecture Rooms Syndicate. Later he became Secretary to the Syndicate, and held both offices until he became Registrary twenty-five years later.

J. continued to use his rooms in Trinity, but to an everdecreasing extent. Owing to his declining health, Dr. Clark went less and less into society, and J. was more and more at Scroope House, helping his mother to maintain the hospitable traditions of the place. As J. could not see his way to take Holy Orders, his Fellowship came to an end this year, but he was allowed to retain his rooms in College for several years later, as he was understood to be working at the College records; and indeed he did work at them from time to time, but, except as regards those which relate to the buildings, little came of it. Shortly before his death all these records were fully calendared and returned to the Trinity Muniment Room. For a few months he acted as Librarian at Trinity, being Deputy for the Librarian, who was away, and as the following extract from a letter to his friend, Charles Gray, Vicar of West Retford, shows, he was also doing other work for his College:-

\section{6 th July 1866.}

"This place is very quiet. I have got a great deal to do in the Museums, which I think it politic to get done as soon as possible: that when I am free nothing may impede a continued absence on the continent. Also Sedley 'Taylor ${ }^{1}$ has delegated to me no sinecure. The looking after all these alterations entails incessant labour-and what with Arthur, ${ }^{2}$ the Master, and the Seniority my hands are quite full. The Hall will be wonderful. I hope to carry

' J. was now acting as Junior Bursar for a time, as Deputy to Mr. Sedley Taylor, and the Great Combination Room was then done up under his direction, as well as the Hall.

2 The well-known decorator. 
a new system of lighting-a great effect in brasswork. The M[agister] C[ollegii] is favourable. I have been to Ely to-day to confer with that great man. The Bishop was ill -knocked up with the Conference of Rural Deans, of which the M.C. gave a very sarcastic account.

"Are not these public events almost past belief? I am delighted on the whole-especially at the magnificent position Napoleon has achieved, really by sheer force of superior intellect. And we are very rightly served in being completely left out. As a thorough Italian, I feel bound to sympathise with Prussian successes: and I am so thankful for the upset of Hanover, Darmstadt, Nassau, \&c. There will be fewer Germans for our Royal people to marry.

"People dine in Combination Room, I am told, in a Christian manner. I am going to order matting for it to-morrow. Only fancy, they had taken up the carpet, and Hoppett, \&c., went clumping about on the bare boards like so many ponies!"

As Mr. Gray writes, J. "was always 'after' improving things-the finances of the A.D.C., the lighting of the Hall, the warming of the Trinity Library," when he was acting librarian. Mr. Gray rightly adds, "Think what that cost in overcoming centuries of prejudice!" In 1866 he was also warming, and, as the letter already quoted shows, decorating the Hall. The idea of putting a large tent in Nevile's Court for a Ball, when the Prince and Princess of Wales visited Cambridge in 1865, was also his, and he carried out many of the details connected therewith.

In fact, in the middle of the sixties J. was still "planning this and planning that," and had not "found himself." To his now failing father he was somewhat of a disappointment, and they differed a good deal about money matters. When I knew him, J. was in this matter so careful that he entered in a book each stamp he used for the A.D.C. and for the many other organisations he managed, and although he ever exercised a rather splendid hospitality, and could be at times, as I have said before, most generous, he never would tolerate waste. 


\section{Lord Desart}

Here I may interpolate an appreciation kindly written for me by Lord Desart, who as Hamilton Cuffe was at Trinity from 1866 to 1869 :-

"I went up to 'Trinity in October 1866, and shortly after my arrival was elected a Member of the A.D.C., where I first met J. W. Clark, who had just ceased to be a Fellow of the College. I had, before going to Cambridge, frequently acted in private theatricals, and to J. W. a love for acting and some knowledge of the Drama constituted ties which obliterated differences of age and position. His interest in the A.D.C. and in the Undergraduates who took part, or desired to take part, in the performances was intense, and mine was only one among many cases in which membership of the A.D.C. led to an acquaintance which developed year by year into the closest ties of friendship. J. W.'s enthusiasms in many directions were inspiring, and his manner of expressing them sometimes rather overpowering, while the charm to a young man of the total absence of anything approaching 'side' or assertion of his position, and of the terms of perfect equality on which he met the youngest undergraduate, was great indeed. We never thought of him as a Don, but as one of ourselves-and it was only when in conversation we realised the breadth of his thought and the range of his learning, that we fully appreciated the value of the gift of his firiendship.

"At his mother's hospitable table at Scroope House, before he married, and in his and his cultivated and devoted wife's house later on, we who were privileged to be his friends met not only our contemporaries but former undergraduates and resident fellows, of whom I principally recall Prof. Newton, Mr. Percy Hudson (now Canon Pemberton), and my distinguished friend still with us, Dr. Henry Jackson.

"J. W. was at that time 'Superintendent' (I think that was the name of his office) of the Museum of Zoology and Comparative Anatomy, and he often gave any of us who cared for it the privilege of a morning there among his subjects, and brought for us dry bones to life.

"I left Cambridge in 1869. Afterwards, when at the Bar, I always stayed with him on Circuit at Cambridge, 


\section{I04 F. as a Bachelor}

and frequently at other times, till his death, while we often met in London.

"His family life was perfect, as it seemed to me. His fount of perennial youth never failed, and to young or old he was the equal in age, with the same interests and enthusiasms as those when I first knew him-the same unselfishness and desire of making others happywith the gift for attaining that end.

"Of his University career I can say little of my own knowledge, but he often talked to me of it, and I know that the work was to him no mere duty, but an earnest desire for the best that could be attained. $\mathrm{He}$ was an eager controversialist and did not spare opponents, but I do not think differences of opinion ever led to personal bitterness against him, for anything he said or did in his public life was the outcome of obvious sincerity and desire to do what was right without any touch of personal ambition, or seeking of personal ends.

"His high character, his personal charm, his many interests, made his friendship to me among my most valued possessions, and I doubt whether there was any man at Cambridge of his time whose close friends could be found to range over so wide an area, or to include men belonging to so many generations of those who had passed through the University."

In the summer of $1867, J$. went with Henry Powell to Paris, where as usual he spent several days dining and visiting the Français; later they made a short tour in Normandy, and returned in time to attend David Powell's wedding in July. During these years he saw a good deal of Sir William (then Mr.) Flower, Curator of the Museum of the Royal College of Surgeons, later Director of the Natural History Department of the British Museum, who, by the way, subsequently shared with Henry Powell the responsibility of being godfather to J.'s second boy, Willy. J. and Flower were always on the best of terms, and were mutually helpful in many ways. Other zoologists who visited him from time to time, and who took a lively interest in his Museum, were Professor Rolleston of Oxford, Mr. O. Salvin, Dr. Günther of the British Museum, 


\section{Henry Jackson}

Dr. P. L. Sclater, Secretary of the Zoological Society, Professor Boyd Dawkins, Colonel H. W. Feilden, and Professors Marsh and Agassiz from the United States, Mr. Du Cane Godman, and many others. Other helpful friends in his Museum work were Professor Milne Edwards of the Jardin des Plantes, Professor Gervais, and Professor Perrier, and J. seldom visited Paris without seeing them.

There are many who have very pleasant memories of travel with J. Professor Henry Jackson writes :-

"J. was a quite delightful travelling companion. In the earlier part of the long vacation of 1868 I had been with my friend and colleague, Mr. Joseph Prior, first at Marienbad, where he took the waters and dieted, and later at Ischl, where he recruited after the cure. Towards the end of August, J. joined us on the way to Vienna; and in that delightful capital we spent eight or nine days. We saw Faust and Lucrezia Borgia at the old opera-house, and Torquato Tasso, Marie Stuart, and Adrienne Lecouvreur at the Hofburg theatre. We frequented the great picture galleries. We visited the gardens of Schönbrunn. Under the guidance of a friendly professor we walked to the Leopoldsberg, and saw the panorama of the Danube. Presently Prior left us to go home, and J. and I started for Graz and Trieste. Our scheme had been to go to Corfu; but we found that, if we were to do so, we should have to wait a week or more for a boat; so we revised our plans, and crossed the Adriatic to Venice.

"I think that we were there no more than four or five days : but J. knew Venice well, and he was a born cicerone. We saw a great deal; and, what is more, we saw it comfortably. I never felt that I was being hustled. The truth is that J.'s talent for organisation served him well in travel as in everything else. In planning the order of the day's sight-seeing he was as careful as he was in putting a play upon the stage: and there was the same attention to scenic effect. For example, he contrived that I should have my first view of St. Mark's from a particular angle of the piazza. (In the same way at Rome, bringing me from behind the Palazzo del Senatore, he exclaimed, 'That is the Forum!' I regret to say that in this instance 
the coup de théatre was unsuccessful: for at that time the authorities were busily manufacturing antiquities on the spot, and I was brutal enough to answer: "That stonemason's yard?') At Venice, as indeed everywhere, we thought first and chiefly of pictures : but we found time to go to Murano, and even to remote, lonely, primitive, Torcello. Moreover, we bought innumerable photographs, which afterwards caused us perpetual annoyance. For at every custom-house the inspector called upon us to open the bulky parcel: and it was only by eloquence and bribery that $J$. succeeded in staving off the inconvenient demand. Of course he always had his way: the parcel reached England unopened.

"We stayed for a night or two at Padua, at Verona, at Mantua, at Parma, at Bologna. I think that J. had seen all these cities long ago: but his interest was as fresh as ever, and he heartily enjoyed introducing a novice to them. For, to me, Italy, except Genoa, Milan, the lake of Como, and Turin, was a terra incognita. We talked much about many things. In particular we had a standing controversy about Childe Harold. J. held firmly that the traveller in Italy should take Childe Harold as his vade mecum: and accordingly we bought a copy at Venice, and had it constantly in hand. Unluckily the time had come when I cared more for Browning than for Byron: and I shocked J., not only by saying that the raison d'être of Childe Harold was to provide Murray with conventional quotations for his red guide-books, but also by criticising in detail what seemed to me Byron's shoddy sentiment and slovenly style. By the way, wherever we went, J. promptly found some lofty tower from which he could have a bird's-eye view: and he always took the very earliest opportunity of making the ascent. He was completely devoid of the infirmity of Ibsen's Masterbuilder. At Parma we mounted to the drum of the dome of the Cathedral, that we might have a better view of the damaged frescoes : and to my horror I saw J. composedly leaning out of one of the door-like openings and resting his hand upon a projecting bar.

"We spent several days at Florence. We saw Salvini -not yet known in England-both in a piece called John Milton and in a prose version of Othello. As Othello, Salvini was amazing: and he had an excellent Iago. It 


\section{Henry Fackson}

was, I think, at Florence that we saw and enjoyed Il Matrimonio Segreto. We stayed next at Arezzo, Perugia, Assisi, Terni. In Umbria we journeyed in a leisurely fashion, sometimes taking the train, sometimes driving, sometimes walking. Several of our walks are still fresh in my recollection. I think of Cortona with a herd of white oxen congregated before the gate; of Lake Trasimene, where we speculated about the battle; and of the Clitumnus and its source. Then again at the gate of the modern cemetery of Perugia there was a dispute which reminded me of one of Virgil's eclogues. There were three persons concerned. J. pleaded that a Perugian cabman had contracted, for a sum named, to take us to an Etruscan cemetery at some little distance from the city: the cabman replied that, for so small a sum, he could not think of taking us, and could not be expected to take us, further than to the modern cemetery: and a casual passer-by, having heard the arguments, gave his award, which was, of course, in favour of the cabman. It was, I think, at Terni, after a drive through wild country, that, when we had dined comfortably, J. said, 'Do you know, I thought this morning that we were in for brigands!' 'So did I,' was my answer.

"We reached Rome late in September. J. knew Rome almost as well as he knew Venice: and he 'staged-managed' me, if I may be allowed the phrase, with his customary skill and kindness. We made it our rule to see what was important twice, and we did not try to see everything. I think that we were in Rome no more than eight or nine days: but I found at my next visit-when, by the way, Rome had ceased to be Papal-that I had seen more of what was best worth seeing than many who had resided for months. At last the day came when we must drink at the fountain of Trevi and apply for our passports. Then, having recovered our photographs, which we had not been allowed to take into the city, we went to Leghorn; from Leghorn by sea to Genoa; from Genoa to Turin; from Turin over the Cenis by the Fell mountain railway to Paris. I think that we saw $L e D u c J o b$ at the Théatre Français.

"I regard the long vacation of 1868 as one of the best times of my life. During the first half of it I was begin- 
ning to know something of Germany and of German literature, and I heartily enjoyed my weeks with Prior at Marienbad and in the Salzkammergut. But Italy, with its beauty and its associations, has a fascination peculiar to itself: and then there was, what I now first fully realised, the delight of the wandering life. Of course J. and I had our discomforts and our explosions. In an Italian railway carriage one of us would say, 'Parasite on the left ankle,' to which the other would answer, 'Mine is under the right knee.' In those days many notes issued by provincial banks had only a limited circulation. So it was necessary for us, when we left a place, to get rid of our local paper. If by any accident $J$. still had local notes in his possession, he invariably offered them to the ticket clerk at the railway station, and the ticket clerk invariably refused them. Then there would be a scene. J. would wax eloquent: and, when I began involuntarily to laugh, English 'swear words ' addressed to me contrasted comically with voluble invocations of saints addressed to the original offender. Once he seized the ticket clerk in his box, and shook him violently. Once he tore up a note which a waiter had refused, and flung the pieces in his face. But all this was part of the game. The squall blew over as quickly as it had arisen. Towards the end of our time together, there were conversations which I have always gratefully remembered. In $1868 \mathrm{~J}$. still thought of addressing himself seriously to zoological work, and he never missed an opportunity of adding to his catalogue of skeletons of whales.

"I was with J. and others at Paris on several occasions. In particular, at Easter, 1868, Montagu Tabor and I, and J. and Alfred George Day, followed very nearly the same route to the south of France, sometimes joining company, sometimes separating. 'Together, we drove to the Camargue, that we might see the bulls at home; we saw the nine selected bulls make their solemn entrance into Arles; we watched the bull-baiting in the amphitheatre; and we admired the Arlésiennes and their picturesque black and white costume. A few days later, April 17, J. and I walked from Nice, by Ville Franche and Eze, to La Turbie, and thence descended to Monaco. There, some members of the party lost their money: one lost his temper: another, who had not played, left early the next morning, 


\section{His Love of France}

that he might not receive notice to quit the hotel. At Paris in those days, J. having not yet found out the hotel which he frequented in his later years, we used to establish ourselves at the Hôtel du Louvre, au quatrième; and in general we dined at Tissot's, the Bouf à la mode in the Rue de Valois. (The mention of this restaurant reminds me how once, when J. had ordered the dinner, Alfred George Day, more in sorrow than in anger, uttered the words, ' Two white meats! J. W.!! What a solecism!!!') As a matter of course, we went to the theatre every night.

"In the foregoing paragraphs, I have tried to recall happy days spent in J.'s company long ago: I have not attempted to describe his accomplishments, his versatility, or his sincere and affectionate nature. But there is one thing which I cannot leave unsaid : during the half century which has passed since I began to know him in 1862, he and his have always been to me and mine the kindest and truest of friends."

Several times I, too, have travelled with him in France; once when he was weak, recovering from an illness, and even unable to enjoy his much-beloved French cookery, yet something in the French air always gave him fresh life, and he was bright, full of energy-toujours gai. He would be indefatigable in sightseeing, and his knowledge of architecture, of monastic orders, of libraries, knowledge he never tired of imparting, without in the least wearying one, made him - and here is a point I must record at once or I may forget it later: J. never was and never could be the least bit of a bore-made him the most cheerful and delightful of companions. He spoke French fluently, and liked to speak it, and had a peculiar gift of getting on well with "our lively friend the Gaul." All the little officialisms of our friends which, had they occurred in this island, would have led to a series of violent explosions, were in France accepted as natural to the scenery, and passed by with many polite phrases and much lifting of hats. In Paris, J. always stayed at a little hotel in the Rue St. Roch which, I confess, when he first took me to it, struck me as extraordinarily stuffy. It consisted of two contiguous houses, each with a single narrow 


\section{I O}

\section{7. as a Bachelor}

staircase, from which opened on each side and on each floor a little room, furnished with red plush and faded gilt. Each room had a loudly ticking and pretentious gilt clock, animated by some horrible pneumatic agency, so that the only way I could find of stopping mine was by putting pieces of sponge into its interior. There was no through ventilation, every window opened on to the noisiest of streets; there was no lift, and the staircase was as high as Loudon Dodd's after the Roussillon; yet J. liked it, and returned to it again and again till his death.

Ever since his resignation, Dr. Clark had been failing more and more in health, and for long before his death was confined to his own rooms. On the 15th of September 1869 he died, an event recorded with Spartan brevity by that indefatigable gardener, his wife, in her diary-"Sept. 15th: Dr. Clark died 3.30, in his eighty-second year. Gathered Louise-Bonne pears."

Mrs. Clark had devoted herself to the care of her husband throughout his long illness, and had not left Cambridge for a single day for some years; and now J. wisely took his mother away, first to Devonshire, and later for some months to the Riviera. They were abroad again in September 1870, and were at Bellinzona on 3rd September, when, at luncheon, as Mrs. Clark records, "a telegram was brought in announcing that the Emperor of the French had been taken prisoner"; later they were in Venice when the news came of the entry, on 20th September, of the Italian army into Rome through the breach in the walls at Porta Pia. "The city was en fete-banners, illuminations, San Marco and the shops all closed." They returned by Bâle, Strasburg, Mannheim, Cologne, and apparently were in no way incommoded by the military operations. If he had been, $J$. would have mentioned it, for he did not like the Germans and he never concealed his dislikes.

J.'s contemporaries in the early and middle sixties undoubtedly regarded him as little better than a gifted, versatile 


\section{His Versatility}

dilettante. It was suggested that he should issue a card: "Balls, Funerals, and Theatricals attended." It was recognised that he could work, and work hard, at some heavy task such as the muniments of Trinity, for three weeks or a month, and then the interest seemed suddenly to evaporate, and the work hardly begun was hastily dropped. Then, as later, he was doing an amazing number of things-hunting, arranging private theatricals-like Nicholas Nickleby, he adapted French plays and took a hand in coaching the company and in painting the scenery-going perpetually into society, arranging and cataloguing the Museum of Zoology, collecting and setting up specimens, writing the Reports of the Museums and Lecture Rooms Syndicate, helping in the construction of the new Science Buildings, taking an active part in University affairs, giving popular lectures, tutoring, and occasionally teaching, collecting books, travelling, and gardening. Later in life he gave up hunting and dancing, but he even increased this catalogue by further activities: on the scientific side by the writing of zoological papers and the delivery of zoological lectures, and on the literary side by his treatises on architecture, monasteries, and the care of books. He was attaining greater concentration, greater persistency, and, if one may use a trade unionist's expression, his numerous activities were being "keyed up."

Without being in any of these activities, except perhaps in archæology, quite in the first flight, $J$. in after life achieved distinction in many paths, and a distinction which would have pleased and satisfied many a specialist; but at the time we are writing about we can only say he was rather like a superSkimpole, without Harold Skimpole's selfishness and disregard for others. Like Skimpole, he was an attractive, spoilt child -to some extent he remained so to the end, but in these days his whims, his caprices, and his petulance were far more marked than later, though he never lost them. On the other hand, he soon shed the irresponsibility and the waywardness of his younger days. 


\section{I 2}

\section{7. as a Bachelor}

His father's illness and death, and his mother's need of him at home, were the first influences which helped to bring about the change. Although outwardly it would never have done for $J$. to take too prominent a part in directing the establishment at Scroope House-his mother was far too imperious to tolerate that-yet his wonderful gift of getting the best out of servants must have had a soothing effect on the household; at any rate we hear less of the devastating domestic troubles which disturbed J.'s boyhood. Towards the end of the sixties, Mrs. Clark and her son were giving, nearly every Sunday evening, those delightful, small dinners, mostly purely domestic and informal, which will never be forgotten by anyone who was privileged to take part in them. To the guests the house seemed admirably ordered.

As we have seen, as far back as 1864 J. made allusion to the family of Sir Andrew Buchanan, at that time Ambassador at Berlin; from time to time one of his sons is mentioned either as dining with $J$. in town or spending a day or two at Scroope House. He had been great friends, as I have already mentioned, with Edward Buchanan, who died in 1870, and afterwards with Andrew, a younger brother. As time goes on, these entries become more frequent, and towards the end of July 1872, Eric Buchanan ${ }^{1}$ and his sister, Miss Frances Matilda Buchanan, spent a week at Scroope House. The diaries are as meagre as ever, but for once J. abandons the daily entry of where he dined, and records that he went with Miss Buchanan to Ely on one day, and on another took Miss Buchanan in a boat on the Cam. On the 25th January of the following year Mrs. Clark records, "John engaged to Fanny Buchanan at Pau." J.'s entry of the same date is "Fine day. F. B. accepted me."

1 The present Baronet. 


\section{CHAP'TER VI}

\section{J.'S MARRIAGE}

The best thing J. ever did was to propose to and marry Miss Frances Matilda Buchanan. There had been some feeling of hesitation on the part of Miss Buchanan's family as to the expediency of the engagement on account of the great divergence of age, $J$. being twelve years her senior, but never was a union more complete or more absolutely happy. J.'s perennial youth of spirit, the keynote of all that made his life such a fine thing and so worthy of record, bridged the difference in years, while his highly-trained brain acted as a constant stimulus to her intellectual power, making her capable of taking keen interest in all his many and varied pursuits. On the other hand, all J.'s friends soon found out what a softening and mellowing influence the constant companionship of one of the best of women could exercise over a nature whose angles had never had much chance of being smoothed down in domestic life. Devoted as he was to his mother, their strong wills inevitably came at times into collision. Mrs. J. was always the peacemaker on such occasions, and her unobtrusive goodness and intense spirituality awakened a response in $J$. and made a Churchman of him to an extent that might have seemed impossible to those who knew him in his unorthodox youth. Two instances of this may be quoted. In 1901 he became Churchwarden of his parish church, St. Mary's the Less, as successor to the late Mr. J. Hamblin Smith, and serving in this capacity until his death, was tireless in his efforts to raise money for Church purposes, while in the last year of his life he joined the Committee which organised a great meeting in the Guildhall in defence of the Athanasian Creed, and enter- 
tained Lord Halifax who was the principal speaker. He meant to have spoken himself, had not his doctors stopped him at the last moment from going to the meeting.

Miss F. M. Buchanan was the second daughter of Sir Andrew Buchanan (1807-1882), a diplomatist who served his country in almost every European state and two transatlantic capitals.

Sir Andrew entered the Diplomatic Service in 1825, and for a time was at the Embassy at Constantinople; in 1830 he was attaché at Rio de Janeiro, but returned to take part in Sir Stratford Canning's special Embassy to the Porte (1831-2). After a few years at Washington he again took part in a second special Embassy to the Turkish Government, that of Sir Charles Vaughan (1837-8). Later in the year he was at Petersburg, then at Florence (1841-4), and Petersburg again as Secretary of Legation from 1844 till 1851. There Mrs. J. was born. In the next ten years he resided successively at Berne, Copenhagen, Madrid, and The Hague. In 1862 he was Ambassador Extraordinary and Plenipotentiary to the King of Prussia; in 1864, Ambassador Extraordinary to Russia ; and in 1871-1878, Ambassador to Austria. Sir Andrew retired from the Diplomatic Service in 1878, but only lived four years to enjoy his pension. He had been made K.C.B. in 1860, and G.C.B. in 1866, and sworn a Privy Councillor in 1863. He received his baronetcy the year he retired. Sir Andrew had married, in 1839, Frances Katharine, daughter of the Very Rev. Edward Mellish, Dean of Hereford, who died in 1854. Amongst his other children were the Right Hon. Sir George Buchanan, since 1910 Ambassador at Petersburg, and Lady Bonham, whose husband was Minister at Belgrade and later at Berne.

The engagement gave great pleasure to J.'s Cambridge friends. The following is the letter of congratulation sent him by Professor Newton :-

1 Feb. 1873.

"MY DEAR CLÂRK,-I congratulate you with all my heart. I am so unlucky as seldom or never to be surprised, and your news does not astound me, and yet I am no wiser 


\section{Alfred $\mathcal{N}$ ewton}

than my neighbours. Read the riddle as you like. I don't profess to say I knew, before I got your letter, how to "chercher la femme," but that there was a someone I felt morally certain for the greater part of last term. I have arranged with William Stubbings and Bridge that a function involving the benevolence of the Hymeneal deities shall be performed on an early day in front of the skeleton (alas, unarticulated!) of Bison europaeus. To do this with proper effect there are certain obstacles-e.g. the north court of the Museum yard is, as you know like a stone-mason's shop, and though one of the blocks may serve as an altar, the oolite chippers will not form an appreciative audience. Again the inner yard (and indeed, for the matter of that, the whole place) is overrun by Michael Foster's dogs-I actually found four (4) loose to-day (and you may imagine, or rather you can't imagine, my wrath) -so that I dare not have a valuable skeleton like a Zebra's exposed to their teeth. Still I hope the affair will come off with becoming solemnity.

"But joking apart, I am sure I wish you every happiness and I trust also that your marriage will add to that of your mother, to whom, as time gets on, the gaining of a daughter will or ought to be an increasing comfort.

"We buried poor old Sedgwick ${ }^{1}$ to-day ; the funeral was very well conducted, but the weather was bitterly cold. However, I dressed myself à l'arctique, and am none the worse. I was requested to be at Trinity Lodge at $\frac{1}{4}$ 11 precisely. I got there at $11 \frac{1}{4}$, and found myself in lots of time. All the 'swells' assembled in the big dining-room, and we were ex necessitate rigged out in gloves and scarves. The minor dignitaries met in the Combination Room, and fell into the procession as it came round the court. I have no idea how many people joined-perhaps 300 . We had the Bishops of Ely and Norwich; Stanley, who looked as if he should have liked to carry off the corpse to his own collection at Westminster; Walpole, Beresford Hope, the inevitable Airy, sundry Deans, a few Lords, Masters of public schools and the Mayor of Cambridge. My own order (and Sedgwick's) was of course very strongly represented, in fact I think Vernon Harcourt was the only absentee. . . . So we walked

${ }^{1}$ Professor of Geology, 1818-1873. 
round the court in a shower of sleet. The Master, Deans, Chaplains and Choir met us at the big Gate and sang us into the chapel. ... Hotham read the lesson, and the Master of — sat by the side of the head undertaker, who from the use he made of his prayer book appeared to be the more devout Christian of the two. . . . It is usual to extol the beauty of our funeral service, and good it certainly is in a small way-a country churchyard for instance-but it is a failure on a large scale, with a choir. -Now, good-bye, Yours very truly,

\section{"Alfred Newton."}

The year 1873 was a busy year for $\mathrm{J}$. He made five visits abroad in the first nine months to see Miss Buchanan-twice in the spring to Pau, once to Paris, and in the autumn twice to Vienna, where his future father-in-law was then British Ambassador. On one of these journeys he records that he travelled in an "American sleeping car."

It had been arranged that $J$. and his bride should live at No. 1 Scroope Terrace, but first it was necessary to get rid of the then occupier. In the following letter he tells Miss Buchanan how he did it:-

Scroope House, Cambridge, March 9, 1873.

"I went to see my tenant, Mr. S—, yesterday. After waiting some time on the doorstep the door opened about 6 inches, and a very dirty hand placed on the step a broken sauceboat with a halfpenny in it. The owner of the hand evidently mistook me for the milkman! 'Is Mr. S in?' I inquired. The face belonging to the hand thereupon showed round the door, and was seen to be extremely dirty, like the hand, and both belonged, I take it, to a charwoman. 'I believe he is,' she replied; 'did you want to see him ?' 'Well, I suppose I should not have come here if I had not,' I answered, not in the best of tempers. Then I sent my card in, and presently was admitted. When I got in my heart died within me, as one might say. You never saw a house in such a state-never, save in some miserable court or back alley in a bad part of London. However, I dare say that an able-bodied charwoman scrub- 


\section{Scroope Terrace}

bing every day for a week will do wonders; and I shall take care to have the place painted and papered from top to bottom. Mr. S- I found seated in his study, on the floor of which was a substance that had once been a carpet of the Turkey sort, but now a mass of rags. In the middle of the room was a sort of island, formed by a round table covered with books and papers, with writing materials, \&c., and tolerably clean and tidy; but all around was an angry sea of torn papers, volumes pitched hither and thither, etc. etc., and all covered with thick dust. I must own that the cleanest thing in the room was the master thereof. He was civil and friendly, as he always is, and expressed his willingness-nay, anxiety, to go out at once. I said I did not want him to go before Midsummer, really wishing him to go at Michaelmas; but I thought if I said the earlier date I should be sure to get rid of him when I actually wanted him gone. I said I would do all I could to help him, and so we parted. I shall go to a house-agent to-morrow, and set him off making inquiries for a house for him."

The following fragment seems to have been written, to Miss Buchanan, from Ratisbon after J.'s second visit to Vienna in the autumn of this year :-

". . . It is very nice to think that we are once more in direct communication. Forgive me anything I may have said in my anxiety. David said in his haste, 'All men are liars,' and he was not far wrong. Perhaps the Poste Restante at Jerusalem had detained a letter from Bathsheba-who knows? And I shall certainly never believe a Poste Restante official again. ...."

The following was sent by J. to his mother during his first visit to Vienna, which occupied most of August:-

\section{Vienna, 9th August 1873.}

"As Fanny has sent you such a long description of the Fête at Schönbrunn, I need not dilate upon it at length. It was very amusing to see for once, but it struck me forcibily that life in those lofty regions must be dull, to judge by the bored expression of all the faces. It is wonderful 


\section{I 8}

\section{Z.'s Marriage}

that people like the Emperor or Empress, who have spent their lives in receiving visitors, should have so little to say to them. He looks as shy and awkward as if he was receiving for the first time: and she, though she is the most graceful and beautiful creature in the world, has not a word to say for herself. She is singularly attractivea marvellous mixture of a girl and a woman, being thirtyeight years old, with the look of seventeen : and her long hair hanging down to her waist increases the youthful effect."

The wedding took place from the house of an uncle of Miss Buchanan, No. 33 Lowndes Square, on the 9th December 1873. This uncle, a bachelor, Sir George Mellish, who in 1870, on the death of Sir George Giffard was appointed Lord Justice of Appeal in Chancery and a member of the Privy Council, made a London home for his nephews and nieces. When he died in 1877, Lady Bonham bought the remainder of the lease of this house. They were married in Trinity Church, Sloane Square, and later J. and Mrs. J. left for the south coast, but returned to Scroope House for Christmas. Before leaving for their real honeymoon journey they moved their furniture into No. 1 Scroope Terrace, and on the 7th January 1874 they started on a trip to Algeria, which lasted just four months. J. kept a full diary, but, except in so far as he was trying to collect specimens for the Museum, their experiences differed but little from those of other travellers in Algeria, and it seems unnecessary to quote from it at any length. While in Algeria, with his usual energy, he revised Murray's Guide to that portion of Northern Africa.

The following extracts from two letters from Professor Newton to J. while in Algeria are typical of the Professor's humour and attitude to the Museum and to the University. To all who knew and loved the Professor his statement that "if they want to bargain with me they must agree to my terms" is essentially characteristic; like the China Shepherdess, the Professor was "always open to discussion," but, like the Rev. Septimus Crisparkle's mother, he always looked as if he would "like to see the discussion that would change his mind ":- 
Cambridge, 26th February 1874.

"I have to thank you for your two agreeable letters of the 16th and 21st. I am delighted to find that your excursion into Kabylia answered so well. It must have been luxurious-driving about in a carriage, and within range of Lions! Mercy on me, I should have thought all the time of the myth of the Salisbury Mail Coach and the fugitive from Wombwell. A Lion's (t) skeleton must be had. Pray apply the screw to Playfair, so that he will screw General Chanzy. Caracals and Gazelles are very well in their way, but if you were to bring back a shipload no one would (myself excepted) think the better of you, whereas if you bring back a Lion you at once become metamorphosed into its metaphorical equivalent, and even Heads may ask you to dinner. The Fish collection also I greatly applaud-the more you bring, the more comfortable are things likely to go here, and I must say they have been looking squally. I gave your message to Bridge. He had already (he told me) looked out the history of Chimora, so I said he had better send it (N.B. It is a form we much want, that I have known for a long time, only I don't expect you will get it now), but I begged him to add that of Murcna, which I understand he has done. Nature, no doubt, would pay you its usual niggardly sum for papers on Barbary Ape and Lion, but its pay is so small that I have always declined (ever since my first article) receiving any. If you want to write for money, send your articles to the Fieldthere they do pay. ....

"The prevalent belief I take it to be is that the Professor of Zoology ought to look after the Museum. I need not say how absurd this is, but it is (I am persuaded) the prevalent belief. Of course it has been easy for me when I have been talked to on the subject, to show that I am not required to take any part in the management of the Museum. Whatever authority I have, or am supposed to have, was conferred upon me after my election, and of course it remains for me to refuse any part or all of such authority. One notion that underlies it all, is that your salary (!) may be saved to the University, which of course is false, because I should never, under any circumstances, take on me such additional duties without an equivalent. 
What they might do with my successor is another matter, but if they want to bargain with me, they must agree to my terms, and, as I have said, they may depend upon it the University would in that case be the loser."

Magdalene College, 15th March 1874.

"I have been obliged to wait for Sunday before answering your letter, as I have [been] so busy all this last week, and there has been no particular reason for writing sooner. I saw Madame Mère on Monday, and she then told me of your doings on the Atlas. . . . You may depend upon it that your pet scheme of abolishing the Heads never had a chance of being carried out-whatever party was in office. 'The Crown would never hear of the dethronement or abolition of the Master of Trinity, and so long as there was such a functionary other Colleges must have their Masters. The only thing that might have been done, and may yet be done, is the taking care that Masterships were not sinecures, and providing means to fill them properly. Any increase of salaries must come from more successful working of the Press-but University Officials might be united with Fellowships, as many people have long thought."

On the 25th September their eldest son Edward Mellish was born, and their younger son William Henry on 1st January 1876.

For some time the name of Frank Balfour had been recurring at frequent intervals in J.'s meagre diaries. He was the youngest and the most brilliant of Mr. A. J. Balfour's brothers, and he met a tragic death in the Alps in the summer of 1882. $\mathrm{He}$ and $\mathrm{J}$. were devoted friends, J. doing all that an older man could do to help forward the more distinguished career of the younger. In 1875 Balfour and Milnes Marshall started a class in Practical Zoology, and from that time forward the subject was thoroughly well taught at Cambridge. A reference to Appendix I will show that the years in the middle of the seventies were very active years at the Museums. J. was then writing a series of scientific papers on his favourite sea-mammals and on one or two other groups, from 
time to time contributing a more or less popular article to the magazines, and occasionally giving a popular lecture on Zoology.

In the summer of $1875 \mathrm{~J}$. and his wife visited the Bonhams at Mödling, and whilst there J. made a short excursion to Berlin to visit the Zoological Gardens and the Museums, which he describes in the following letters to Mrs. J. :-

Hôter du Nord, Berlin, Saturday morning, 14 Aug. 1875.

"I have just arrived here, in the capital of my enemies, after quite the most comfortable journey I ever made, considering its length. I took your advice and a first-class ticket-( 36 gulden if you please!) and was in consequence inducted by the guard into the 'Damen Coupé,' but there were no Damen in it, and not until I had seen the ticket denoting its intended use removed would I set foot in the ill-omened vehicle. It was a pleasant little carriage, roomy and well stuffed, with three seats, along which I reposed comfortably. Soon after leaving Brün the guard came and asked me if I would dine at Böhmisch-Trübau at seven. So I said I would, and paid the large sum of one gulden for a ticket. Seeing that we waited only 4 minutes at that station, I was sorely puzzled as to what was going to happen. But no sooner had we reached the place than a smiling waiter appeared with a tray of white metal, on which, retained in their places by rings of wire, were a soup in a covered pan, a kalbsnitschel and potatoes, a dish of cold meat and pickles that would have delighted Henry, ${ }^{1}$ a bottle of wine and a ditto of water (not much of either to be sure), salt, pepper, bread, and knife, fork, and spoon all rolled in a napkin. It was all very clean and nice and hot, and about two stations on another Polite Person came and removed the platter. Never, not even in my dear native country, ${ }^{2}$ have I been treated so civilly by guards and everybody. One must bear tribute to the good qualities of one's enemies. They are a perfect people - these Germans. It was so curious to see them sitting quietly in the 'Restauration' or on the Platforms at 2, 3 , and 4 A.M., men, and women, and little children, waiting for the trains."

1 Probably Henry Powell.

2 France. 
Hôtel du Nord, BerLin, Sunday, 15 Aug. 1875.

"I have just got your dear letter. Dull indeed! when you have got a performing dog and two Babies ${ }^{1}$-don't talk such rubbish! You're like the young person

'Who was better off than all the other boys,

With an old shoe, and a brickbat, and a dead kitten by way of toys !'

"After writing to you yesterday I went and hunted up Professor $\mathrm{P} \_$, who lives in the University Buildings, just opposite the Opernhaus: and as this hotel is close to that end of the Unter den Linden, I am well placed. He is delightful, a man of the Van Beneden type : but in science far more accurate and decided. He speaks English without a fault or an accent: and his wife, a rotund person, speaks a little. So does a young lady whom I take to be a sort of superior governess. There are six children, three boys and three girls, the two youngest being of the latter sex. They are quite charming, and talk away to me in the full confidence that I must understand them. They asked me to dinner yesterday, at four, if you please, me!!! Over the horrors of that repast I draw a discreet veil. I will only say that Trinity College Hall in the old unregenerate days was comfort by comparison. When it was over they took me to the Zoological Gardens. We went all of us in a tram, nearly filling the vehicle. The Gardens are very extensive, about sixty acres, so each animal has a small paddock to disport himself in. 'The collection is very extensive and good. Of course there is the inevitable restauration and orchestra, etc. The 'entrepreneur' pays the Gardens 10,000 thalers a year-and still makes it pay! There were several hundred people eating last night to the sounds of a band that ought to have given them indigestion. After trailing all round the Gardens, I had an eye to some food and drink, but no! my inexorable friend, on account of the children, dragged me home again. Then I got to bed at last, so hungry and tired, at 10 P.M. Lord! how I hate all early hours. I am so hungry and faint this morning that I meditate a 'bifsteck mit Kartoffeln'-so you see to what I am reduced. I must say they are kindness itself. The collection is mar-

${ }^{1}$ Lionel and Eric Bonham. 


\section{Berlin}

vellously fine. I am very glad indeed I came. It has Otarias that exist nowhere else, and even if it had not, the advantage of discussing the subject with Professor $\mathrm{P}$ — would alone be worth the journey. The German expedition to the South Pole has been fruitful in seaelephants, and we see at last that grand animal stuffed in all the glories of his 16 feet of length, and I know not what of girth, and it is a young animal too!"

In a letter, written on the following day to his mother, J. gives some amusing details of this dinner :-

"First there was a soup, of which Prof. P- himself remarked that it was thin; indeed it had a very pronounced taste of nothing. Heaven forgive me! I said I liked it. With it was served a great mould of rice, which you took portions of and put in. This appetising food was succeeded by a dish of carrots and peas-both very hard and old-and some ham salter than imagination can depict. After this came a large limb of a cow, called veal. It was brown outside and pink inside, and Prof. Pcarved fragments of it with a huge chopper, called a carving-knife. 'This was succeeded by a mould of semolina coloured a pale purple, with some skim milk that by its taste had been boiled before, and that was all. The one good thing was a bottle of port-rwine, which had been given them by the Portuguese Minister, and was the pure wine that is not to be got out of Portugal. Having been up all the previous night, I hoped for rest, but no. I was taken to the Zoological Gardens, which was nice enough. They are very extensive and beautifully laid out, with a splendid collection of animals. There was, of course, the inevitable restauration, where I had an eye to something to eat, but such was not to be my lot. By that time it was eight o'clock, a Christian's dinner-hour in fact, so on account of the children we were all taken home again. On Sunday he said, 'We dine early on Sunday, at three,' so I pleaded that I wanted to work in the Museum and escaped; for by that time I was so hungry that I felt I must have some dinner, so I dined at the Hotel very well indeed. However, as I said before, the Museum is a splendid one: and I would go through all I have done and more for the sake of it." 


\section{CHAP'TER VII}

\section{J. IN HIS PRIME}

IN 1875 J.'s uncle, Robert Willis, Jacksonian Professor of Natural and Experimental Philosophy, died. He had lived partly in London and partly at 21 Park Side, Cambridge, and he left one daughter, who had married Dr. Besant of St. John's College, brother to the novelist, and a wellknown mathematical "coach." Professor Willis was a man of varied attainments. He excelled as a lecturer and teacher in mechanism, as an historian and antiquarian, a musician, an architect, a draughtsman, and a painter! Amongst many other things he designed the West Window at St. Botolph's Church and the wooden ceiling of the Great Gate at Trinity. His advice and help were constantly sought in the days of what used to be called "The Great Gothic Revival." Professor Willis had undertaken to write a work upon the Architectural and Social History of the University of Cambridge, and had at the time of his death accumulated a considerable amount of material for the book; but this was far from being in a fit state for publication, and J., to whom he left his MSS., had now to take up the matter almost dè novo.

J. was also beginning to work at "The Care of Books," in connection with the Architectural History, and the following is a typical extract from one of his letters written to Mrs. J. when on a tour of investigation into old libraries:-

\section{HEREFORD, \\ Thursday, 28th September 1876.}

". . . I spent the day in drawing and measuring the library-cases, much to my satisfaction, and discovered a second library of much interest in All Saint's Church, 
also chained. About this, however, I have failed to obtain any information: as those who ought to know are vacant of lore on the subject. . . . Then it has rained without ceasing ever since I came, and to-day it has been a perfect deluge. I have done my best to complete my notes on the Library, and to see the Cathedral, but with difficulty."

J.'s researches for the Architectural History led him into several by-lanes, and he. was now reading a short series of papers before the Cambridge Antiquarian Society; one of the most interesting of these on the "History of the Church of St. John Baptist, Cambridge, commonly called St. John Zachary," gives an illuminating map showing the disposition of the ground before the building of King's; another paper deals with "The Old Provost's Lodge at King's College, with special reference to the furniture," and a third with the "History of the Peal of Bells belonging to King's College."

Another short extract shows J.'s versatility. He could jump from a seal's skull to Rosina Vokes, and thoroughly appreciate the points of both :-

\section{United University Caub, Pall MaLL East, S.W., 27th February [1877].}

"6. . . Then I went to the British Museum with a seal's skull, and saw Günther for a moment. 'Then back here to lunch with Georgie ${ }^{1}$ (now fully restored to favour), after which to Drury Lane, where the Vokes' are funnier than ever, and one of them plays a cat in a manner delightful to all lovers of animals to witness. These excellent people have entirely reformed the stage as far as pantomimes go and seem to have banished for ever 'legs and bosoms.' Rosina Vokes convulses the house whenever she appears; and she wears a high dress and a long petticoat."

Except as a collecting-ground for the Museum, J. held a poor opinion of the seaside-he preferred Paris. Still, for the

${ }^{1}$ Now Sir G. W. Buchanan, British Ambassador at Petersburg, Mrs. J.'s youngest brother. 
sake of the little boys he was willing to sacrifice himself, and to take active measures in arranging the sacrifice:-

Cromer [1878].

"I now send all the particulars, with a ground plan of the different floors of the house, and my views, which I cannot say are very definite. I should very much prefer coming only for August, but that seems now nearly impossible. Of course if there is a war, ${ }^{1}$ this vile Government of ours will clap on a shilling income-tax, and then no one will stir from home. I suppose it is really necessary to make the expedition. I personally, of course, would infinitely prefer staying at Cambridge; but if the children really require change twice a year it must be done. Otherwise we might retire to the 'native land.' I think it is worth considering what is to become of us in the future if we accustom the chits to a yearly outing. One has only a limited time at one's disposal each year; and I confess I bar the sea as a permanent investment. What, however, shall I do? Shall I sign the agreement at once for the three months; or shall I boldly say I won't bind myself except for two; or shall I wait till the Bonhams arrive? If the plan must be steadily carried out, as I suppose it must, I see no reason for delay.

"As regards our own house, there is a most aggravated and aggravating cleaning going on. How I wish they would let the poor thing alone! Louisa ${ }^{2}$ tried to have the pantry done last week, but that I peremptorily forbade. A greater enemy to scrubbing than myself does not exist."

As a matter of fact J. enjoyed the six weeks he spent with his family at Cromer very much, especially as he persuaded Alfred Lyttelton, who was then up at Trinity and was in and out of No. 1 Scroope Terrace almost as a son of the house, to be one of the party.

During the years 1877-1880, J. acted as Deputy to the Registrary, Dr. Luard, but Dr. Luard must have been back by the Michaelmas term of the last-named year, for I shall never

1 i.e. with Russia. The Berlin Conference was now in session, and $J$. was not an admirer of Lord Beaconsfield.

2 The parlour-maid. 


\section{Dramatic Criticism}

forget at the matriculation of that term how furiously he pounced on me for spelling my second name, Everett, with three "e's," whereas he had seen it in some other list spelt with two "e's" and an "i." He became quite heated about it, and when I told him it was my name and that I must spell it as $I$ believed to be right, I thought he would have ordered me to be led away to some Registrarial dungeon.

About this time J. began a series of articles and reviews for the Academy, and a little later for the Saturday Review. The majority of these dealt with French plays and the Parisian theatre generally, and the writing of them gave him great delight, and no doubt they were made the excuse for occasional short visits to Paris :-

Hôter St. Romain, 8th April 1879.

"I feel quite rich at getting two letters from you by two successive posts - and I am delighted at your long accounts of the chits. I have finished a long article on 'Ruy Blas' for the Academy and sent it off. I have taken vast pains with it, and am much pleased to find that Sarcey, the great critic of the Temps, thinks exactly as I do about the interpretation. I finished my article before I read his.

"... You must explain to Edward that Papa cannot come back quite so soon as his majesty wishes; but that he sends many kisses to him and Baby. It is very pleasant to think that those little people really care about me."

At the end of July Mrs. J. went to Biarritz to see her sister, Mrs. Fox, who was desperately ill, and J. accompanied her as far as Paris. She left Biarritz at the beginning of September, J. met her at Poitiers, and together they made a delightful provincial tour, in the course of which they visited the Châteaux on the Loire:-

\section{Hôtel St. Romain, August 1879.}

"I don't think I care much for the Exhibition. The coup d'ail is wonderful, when you enter from the Trocadero side and have that glorious view of Paris with the 
garden and cascade at your feet. 'The said garden, tho' small, is beautifully laid out, and how they have managed to get the trees to grow, and the grass and the flowers, since April, when it was all a desert, is a mystery to me. There's a lawn like King's Lawn, quite thick and smooth and short, where I last saw a heap of gravel."

\section{Hôtel St. Romain, August 1879.}

"I had the pleasure of 3 hours with Jacques Reubell at the Exposition to-day. The more I see that wonderful place, the more I admire it! As for the 'partie retrospective,' since the Alsace Lorraine Exhibition, such a collection was never seen; and even that was not so arranged. There is all the china that was ever made in France represented under its different fabrics: the great towns and the private collectors have all sent their treasures: there is an armoury that beats almost Vienna and Dresden: there is quite a library of illuminated MSS. and bindings : and last but not least there is a collection of old Japanese lacquer, china, and ivories dating from quite ancient days.

". . . 'Ihe French provincials are a marvellous set. Talk of British ignorance: it is wisdom compared to theirs. I was in Mme. Tresse's shop the other day when a well-dressed woman came in, and asked where 'la galerie de tableaux du Palais Royal' was. Considering it was sold at the Revolution, her question was slightly out of date. Mme. 'Tresse kept her countenance as only French people can, and civilly dismissed her."

Hôtel St. Romain, August 1879.

"It is terribly hot here-so hot that I cannot walk out, or do anything in fact: and am sitting at home in my night-shirt, as the coolest vestment I can find, after taking off everything else. I think a storm must be impending, for the sky is overcast. The glass, however, is said to be rising.

". . . The Figaro to-day is very severe on the Comédie for its journey to England, and says a number of nasty 


$$
\text { F. at "Lord's" }
$$

and unnecessary things about the poor B.P.,1 which really did its little best to receive them properly.

"Milne Edwards came for me this morning and carried me off to breakfast at a delicious restaurant in the Champs Elysées, where we sat in a shady garden, among hedges of ivy, with an awning over our heads. We will go there anon. I am glad to have found it out."

J. mentions in a letter to his wife the great tempest of 1879, which however was surpassed by an even more violent storm two years later :-

\section{Scroope Terrace, 6 th August 1879.}

"The great news here is the storm of Saturday night, which, allowing for all exaggeration, must have been severe, and the floods quite extraordinary. The Cam came down like a tide, and one still sees the debris it left tranquilly lying in places where water rarely comes. Communication between Cambridge and Newnham was cut off, and carts plied to take people through the flood. Most houses have had their cellars full of water, and Sabbatarian Cambridge had to work all Sunday as if it were a week-day."

This summer an incident occurred, the recollection of which always afforded the greatest amusement to Mrs. J. The troupe of the Comédie Française (among them J.'s great friend Delaunay) was acting in London, and J. of course went to most of their performances. Now J., as is well known, never took the faintest interest in any form of sport, except hunting. Consequently he was rather nonplussed when Delaunay asked to be taken to a cricket match. Nothing daunted, however, J. carried him off to "Lord's" to see the Oxford and Cambridge match. Those who sat near them were much amused at J.'s eflorts in his fluent French to explain the game of cricket (of which he was profoundly ignorant) to his French friend.

In the summer of the following year (1880) J. and Mrs. J.,

${ }^{1}$ British public. 


\section{$130 \quad 7$. in bis Prime}

accompanied by Mr. Lionel Cust, went to see the Ober Ammergau Passion Play. Mr. Cust has described their tour in Chapter X.

In $1880 \mathrm{~J}$. commenced his official connection with the Cambridge Amateur Dramatic Club, commonly known as the A.D.C., of which he had been elected an honorary member as far back as 1861. In 1880 the club celebrated the 25th anniversary of its foundation by a dinner, at which the Prince of Wales, afterwards King Edward the Seventh, presided, followed by a very successful performance in the Club Theatre. Unfortunately the social and dramatic successes of the evening were somewhat marred by the consequent financial disasters, the deficit amounting to over $\mathfrak{2 0 0}$. At a General Meeting of the Club to consider what should be done it was decided to have a permanent Graduate Treasurer. On the proposition of the Hon. J. Wallop, seconded by Mr. Chisendale-Marsh, J. was elected to the post, which he held till 1901, when he handed over the accounts into the capable hands of Mr. Walter Durnford. He was then elected Perpetual Vice-President, and in that capacity remained on the Committee until his death. Though J.'s life-long devotion to the stage made all he did for the A.D.C. a labour of love, still his services to the Club were many and varied. As far back as 1870 he saved the Club from threatened suppression by the authorities. He personally interviewed tutors of colleges and drafted the rules under which they consented to countenance the continued existence of the Club. In 1882 he arranged as 'Treasurer for the purchase of the Club Rooms and pledged his private credit to enable the scheme to be carried through. Twice J. appeared in the rôle of author, and at all times he was ready to give his assistance whether as Stage Manager in the Theatre or as private coach in his house, as scene-painter, as prompter, or as property man. But it must never be forgotten that everything he did for the A.D.C. he did in a simple and unostentatious way. As Mr. Tatham writes in his article in the Fasciculus: "Mr. Clark's influence is not to be looked for 


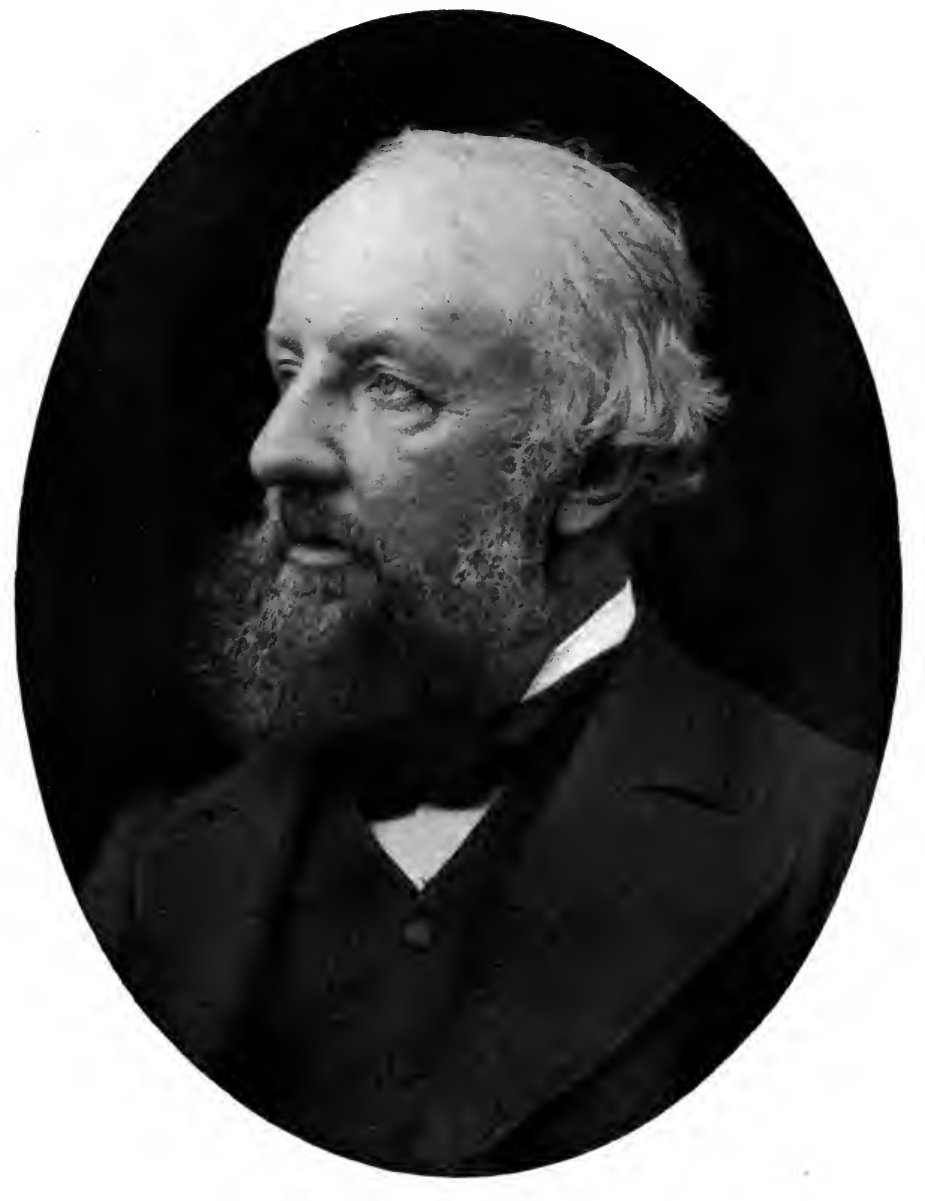

$66 \mathrm{9}$

Circa I 880

From a photograph by A. G. Dew-Smith, M.A. 



\section{The A.D.C.}

in written records, for it has always been quiet and unassuming. Its strength will be found in the recollection of those who have known him and its success in the life and prosperity of the Club."

The following letter from Mrs. J.'s graphic pen to her eldest sister, Mrs. Maxwell Fox, recalls vividly what many must remember in an A.D.C. week or a Greek-play week at 1 Scroope Terrace and afterwards at Scroope House. At such times all the resources of the establishment were put at the disposal of the actors; the house and often J.'s rooms at the Museum were packed with scenery, properties, costumes, etc. Everyone caught the enthusiasm, and everyone behaved as if the fate of the University, if not of the Universe, depended on the success of the play. Yet a friend who arrived in the midst of all the confusion and excitement remembers going round the garden with J. to cut flowers for the dinner table and finding him amongst his many other avocations busy making a cross to send to one of his assistants at the Museum who had lost a child and was burying it that afternoon. This was characteristic of his never-failing thoughtfulness in little things which so endeared him to his friends of all degrees :-

\section{Scroope Terrace, 17 th November 1881.}

"I must send you a playbill, by which you will see the names at any rate of the actors. Delicate Ground had to be left out of the performance last night, as when it was played the first night the curtain did not fall till after 12 o'clock! - by which hour all the men ought to be in College! 'The omission is rather hard on M. Beylard, who had taken a great deal of trouble with his part. The School for Scandal was a wonderful success, especially-marvellous to say-the Lady Teazle, played by a young fellow called Manners who has only lately joined the Club. He really looked a lovely girl in the becoming costume of the time: blue satin train over white 
satin, embroidered with pearls, and large blue satin hat. I lent him my Saint Esprit as an ornament! We had a comic scene on the Monday, when both Mrs. Candour and Lady Teazle appeared here to request me to have their petticoats lengthened for them. The variety of good offices one performs in Cambridge social life is very amusing: one day to lend my bed-table to a man whom I never heard of before but who had been disabled at football, the next to turn dressmaker to the A.D.C.-To return to Lady Teazle: she had the advantage of a small figure and a soft voice, but what surprised one more was her grace of movement and gesture in the drawingroom scenes and the real pathos to which she rose after the screen falls, and the contrast is brought home to her between her husband and her so-called lover. I hear that she is proud (and justly so) of the smallness both of her waist and feet. Agnes ${ }^{1}$ and I are going again to-morrow afternoon, when Delicate Ground will also be played. Mr. Milner Gibson as Mrs. Candour was very amusing, and gave the proper emphasis to the old scandal-monger's- 'they do say,' etc. I hope you are interested in this rather long story, but you know the A.D.C. is a great event in our quiet annual chronicle. I was rather provoked not to have been present last night when $J$. was called before the curtain and received quite an ovation. He quite deserved it, for he has worked hard at the scenery, and thanks to him and Mr. O'Connor, ${ }^{2}$ who said he would have returned to scene-painting for no one else but J., it was quite charming with all the accessories of costume and furniture as perfect as they could be made. It is true that we have hardly enough chairs to seat our guests at dinner-all our Chippendale dining-room chairs having migrated to the A.D.C., and most of the Louis Quinze chairs in the drawing-room, ditto! but one must make these little sacrifices gladly where the drama is concerned. After the performance on Wednesday we went to supper at Mr. Milner Gibson's - the Mrs. Candour of the play. Here comes Willy: 'Mamma, something drefful has happened: 'Toby has fallen down and broke his back leg!' I am relieved to find that Toby is a china $\mathrm{dog}$ in which Willy invested

${ }^{1}$ Miss Agnes Mellish, cousin of Mrs. J.

2 The well-known scene-painter. 


\section{The Paris Mail}

at the bazaar and added to what he calls his 'maggery' of beasts."

Early in $1881 \mathrm{~J}$. had a very unpleasant experience in the Paris mail, an account of which he published in the Pall Mall Gazette. Here is his narrative addressed to Mrs J. :-

$$
\begin{aligned}
& \text { Hôter St. Romain, Rue St. Roch, } \\
& \text { [Wednesday,] 19th January } 1881 .
\end{aligned}
$$

"I hope you have not been anxious about not hearing from me. I couldn't write, and I couldn't telegraph, at least not till to-day, pour cause. I left London on Monday evening by the mail, and reached this this morning at 3 A.M., having been thirty-one hours en route! May I never have such an experience again! First, we were late in getting to Dover, having to stop frequently to test the soundness of the wheels owing to the frost, then the passage took three hours instead of one and a half, because first it was exceedingly rough, secondly, the company had chosen to put on one of their oldest and smallest boats, and thirdly because from sheer laziness they did not put the luggage into the hold at starting. After half an hour's kicking about it got loose, a heavy sea having struck the vessel, and we had to heave to en pleine mer to put it down. Of course it all got wet, and it's a mercy it was not washed into the sea. I remained on my back in the cabin, and slept a good deal, but had the passage lasted fifteen minutes more I should have been ill like most of the others. We left Calais at 2 A.M. an hour late, and at 4.15 came to a sudden stop. The engine was too weak, and the driver too cowardly to face the snow, for as a train passed us presently going down, there was evidently no reason for his stopping when he did. It was blowing a hurricane; the gusts shook the carriage, and the snow penetrated through the chinks and crannies, and lay in heaps in the corners. No one came to tell us where we were, or offer any consolation. When day broke we woke up, five of us, two Frenchmen and three English, and conversed wearily till eight, when Papa's curiosity induced him to leave the carriage and seek the guard's van. I could hardly stand for the wind, nor see for more than a yard for the mist of snow. Two engines had been sent up from Etaples, but they could not move us, and the 


\section{I34 7 . in bis Prime}

men said we might be there for any length of time. This was pleasant. At about 10.30 a peasant brought us some milk and bread, and sugar (blessed man). At 12 the storm cleared a bit, and we found that there was a big drift ahead of us, filling all the shallow cutting in which we were. A few peasants were working away at our end, and we could see more at the opposite end doing the same. But alas! the snow and wind began again in a few minutes, and they had to stop work. At last at 2 P.M. the weather really cleared up, and we could see a village at no great distance. Thither we determined to repair, especially as the Conducteur declared that we should probably not be able to move till noon to-day. So we set off across the snow, and found a decent Public where Madame made us excellent soup with bread in it. We were told that the curé would take us in, so we set off for his house. On our way we met his servant, coming to bid us welcome. We found the curé a delightful fellow, with a fine frank countenance and evidently a strong taste for hospitality, for he was laying the cloth and setting the table with his own hands, and dispensing wine to his guests who had already arrived. By 4 P.M. the dinner was ready, when, just as we were going to sit down, the officials of the post attached to the train came up to say the line was clear and that go we must. It was very provoking, but we thought we ought to go, so after a glass or two of excellent champagne, and a mouthful of bread, off we set. We found that a detachment of soldiers had been sent off from Abbeville and had done much already towards clearing the line, and that a big engine was expected every moment to complete the work. It was a grand sight to see the great machine, covered with iron plates, come tearing through the drifts, and pile them up on each side. Then a fire was lighted under our wretched engine, to thaw it, and being made fast to the other, we started at last, at 5.15. We reached Amiens, going slowly, at 8.45, where we got an excellent dinner, and then started for Paris at 9.30. The company thought proper to attach second and third class carriages to our train, so that we stopped frequently, and finally reached Paris at 3 A.M. I am rather tired, but have not caught cold, strange to relate."

J. always felt certain that he missed a very succulent repast 


\section{Le Puy}

on this occasion, and used to tell the story of, I believe, this same curé, who elicited from his housekeeper in Confession that she had stolen a partridge for her own consumption out of his larder. "Comment l'as tu donc mangé, ma fille?" he demanded. "Je l'ai mangé froid, mon père." "Si encore tu en avait fait un salmi!"

In the spring of $1882 \mathrm{~J}$. made an excursion into the centre of France, Clermont Ferrand, the Puy-de-Dôme, Mont Dore, Le Puy, etc. I have only room to quote one letter to his wife, describing the last-named place:-

\section{Hôtel de L'Europe, Le Pux, Thursday.}

"... This is the most wonderful place I have ever seen in all my travels. Imagine a wide amphitheatre of hills, covered with verdure, then in the middle a huge rock, some 600 feet high, ${ }^{1}$ crowned by a colossal statue of the Virgin, and on a sort of step half-way up, the Cathedral, below which are the houses and steep streets of the old town. At a lesser distance from this rock there is a second, not so high, but far steeper, up which you climb by stairs. On the top is a Church dedicated to St. Michael. The modern town is in the plain below. The Cathedral is very fine, a Romanesque choir and transepts, with a nave which has twice been added to. You go up to the west door by a flight of steps, which conducted to the oldest façade, and when they wanted to lengthen it they had to increase the space available by throwing arches over these steps, so that you now walk up under lofty arcades, and finally land in the Church at a little east of the middle of the Nave. The style is very curious. The squares into which the nave is divided are each covered by a dome, like St. Mark's, all of stone; and outside a very pretty effect of colour is produced by alternating the grey lava with white stone."

The terrible tragedy of Frank Balfour's death in the Alps, towards the end of July 1882, overwhelmed J., as indeed it overwhelmed all Balfour's friends. During the thirty years

1 My recollection is that $J$. here rather oversteps the reality and that his description is a little too highly coloured. 


\section{36}

\section{7. in his Prime}

which have since elapsed Cambridge has lost many men of the highest distinction, but never, in my experience, has the University shown evidence of suffering from so irretrievable, so crushing a blow. It was not only that Balfour was leading the world in his special subject, nor was it alone his intellectual gifts which attracted around him the best men of his day, but it was the fact that he had in the highest degree that indefinable quality, charm. He won all our hearts, and his kindness and thought for others was ceaseless. I have heard that he had given up deer-stalking, his favourite sport, and taken to Alpine climbing, because he had a feeling that it was hardly right to kill deer just for the sake of sport. It is characteristic of him that a few days before the accident he had sent a cheque for $£ 150$ to one of his brothers, "to be given to the guide's family in case of an accident, which, however, is extremely improbable." Mrs. J. was away from home, and J. wrote the sad news to her as follows:-

\section{Scroope Terrace, Cambridge, 23rd July 1882.}

" 7 P.M.-All other matters have been put completely out of my mind by a terrible piece of news which has just reached us. Frank Balfour has been taken away from us by an accident of some sort-unexplained-in the Alps, near Courmayeur. This is all that can be extracted from a telegram which was sent to the Master this afternoon. I was crossing the court at 6.30 when I met Watts, the head man in the College office, who told me of it. . . .

"I can't realise that Frank is gone in the least. I suppose it will come upon me more acutely to-morrow."

There are many other letters from and to J. during these sad days, but they are too sacred to quote. J.'s sympathy especially went out to Michael Foster, who had done so much to help Balfour in every way, and whose favourite pupil Balfour was, and again to Adam Sedgwick, Balfour's Demonstrator, who for many months was absolutely crushed by the blow. 


\section{Frank Balfour}

"I feel I must see all I can of Adam, and try and keep him from moping," J. writes in a letter to his wife.

In the autumn there was a large and influential meeting in the Lecture Room of Zoology and Comparative Anatomy to discuss a memorial to Balfour. The University was well represented. Professor Henry Smith came from Oxford, Professor Huxley and Professor Ray Lankester from London, and Professor Williamson from Manchester. Many eloquent speeches were made, and these were afterwards got together by $J$. in a pamphlet. I quote a few lines of Professor Humphry's speech :-

"One could scarcely yet realise that he who had shown so great love for the large subjects of his own work and so great ability in solving its difficulties; he who might be called the teacher of Europe in his own particular subject; . . . should have passed away before attaining anything like maturity; that he who had shown his attachment to this University, and had clung to it in spite of the alluring attractions of Edinburgh and Oxford, clung to it by virtue of his attachment to the place, to his friends, and, above all, to the man who had brought him forward, who had encouraged him in every effort-he meant to Dr. Michael Foster; - that he had been swept away from them by the treacherous precipices of an Alpine gorge. Again he would say, one could scarcely realise it. But alas! so it was, and, so far as he could judge, Cambridge had had, in his time, no greater loss, though its losses had been great and heavy. Whewell, Sedgwick, Henslow, Maxwell and many others had passed away, but he believed that never had there been in his time, or perhaps at any preceding time, such a loss to Cambridge as that of Balfour."

It was agreed to found a fund to commemorate the name of Balfour, and Mr. Alfred Newton, Professor of Zoology and Comparative Anatomy, moved this resolution :-

"That the proceeds of the Fund be applied : (1) to establish a Studentship, the holder of which shall devote himself to original research in Biology, especially Animal 
Morphology ; (2) to further, by occasional grants of money, original research in the same subject."

J. was, as usual, appointed treasurer, and told the meeting that he would inaugurate his office by stating that the family of the late Professor Balfour had expressed their intention of giving $£ 3000$ to the memorial, to which sum Dr. Michael Foster proposed to add $\mathfrak{1 0 0 0}$, which Professor Balfour had bequeathed to him for any scientific purpose to which he might think proper to apply it. There was, therefore, $\$ 4000$ in hand to start with.

In the October Term of 1882 the first Greek Play, the Ajax (the genesis of which Mr. Cust has described elsewhere), was performed, and J. served on the Committee as Secretary and 'Treasurer. Not only did he hold these offices until his death, but he was also the Stage Manager of five plays, i.e. Eumenides, 1885 ; Edipus Tyrannus, 1887; Ion, 1889; Wasps, 1897; and Agamemnon, 1900. Even this does not exhaust the list of J.'s activities in respect of Greek Plays. In the earlier productions not only were the dresses made and fitted on in J.'s house, but the tickets were balloted for there. On 17th November 1885, Mrs. J. records, "Eumenides ballot for tickets went on from 11.30 A.M. to 11.30 P.M.", and when the performances began she notes that on the first three days they asked 19 people to luncheon, 21 to dinner, and 30 to supper. On the last two days of the performances she seems to have stopped trying to count the number of their guests!

This year Mrs. Clark, senior, and J. presented Trinity College with a bust of Professor Clark, and gave a replica of it to the Museum of Zoology. The following year J. began to write a series of sketches of Cambridge men for the Church Quarterly Reviero. They ultimately included Bishop Thirlwall, Dr. Whewell, E. H. Palmer the Orientalist, and Lord Houghton; these with others were republished in 1900 under the title of Old Friends at Cambridge and Elsezohere. Most were vivid sketches drawn from life, and were illustrated from J.'s 


\section{Antiquarian Interests}

almost inexhaustible fund of knowledge of the inner life of the University. He was also responsible for the Catalogue of the very interesting exhibitions of University and College portraits held in the Fitzwilliam Museum in the May terms of 1884 and 1885. J. had in 1883 been invited to serve on the council of the Oxford Historical Suciety, and gratefully accepted the invitation. The same year he became President of the Cambridge Antiquarian Society and was re-elected in 1884. During his tenure of office the University provided " a place in which we can hold our meetings," and the Society made over, under certain conditions, its collections and its library to the University. As J. most truly said when laying down the office in 1885, "In securing Baron Anatole von Hügel as Curator, we have obtained the services of a gentleman in whom knowledge and enthusiasm are happily blended." He also referred to the wonderful casts of sculptured stone-work from Central America which Mr. Maudslay was giving the University, and to the collections of Sir Arthur Gordon. ${ }^{1}$ It was only in 1912 that by the indefatigable efforts of Baron von Hügel these collections were at length adequately housed. J.'s retiring address was on Libraries.

In January 1888 he was admitted to the Fellowship of the Society of Antiquaries, a distinction he really valued.

In 1887 Mr. Coutts 'Trotter, Vice-Master of Trinity, died. He had for years been a great power in the University, and had taken an active share with J. and many others in developing the Science School. At the time of his death he was President of the Cambridge Philosophical Society, and J. was chosen to succeed him. During his term of office J. read a paper on the skeleton of the Rhytina, Steller's sea-cow from Bering Island, now an extinct genus of the rare order Sirenia, which he had recently acquired for the Museum of Zoology. In his valedictory address when retiring from office in 1890 J. gave a detailed and exhaustive history of the Society, and from this $I$ have drawn in the last two chapters of this book.

1 Later the first Lord Stanmore. 


\section{40

On 2nd March 1883, Mrs. J. records in her diary: "House upside down, preparing for the first dinner given by $J$. to the "Family." 'This is a select and very ancient dining club which in those days still drank to the "King over the water," i.e. the finger-bowls. J., when I became a member of the club, acted as Secretary and most carefully preserved the menus and the names of those dining.

The summer of 1884 was very hot, and the heat markedly affected the health of J.'s mother; and it was soon definitely settled that he and his family should move into Scroope House to look after her. The following entry occurs in Mrs. J.'s diary on 4th March 1885: "Slept for the first time at Scroope House." Mrs. Clark, senior, was growing old and was, I believe, glad to hand over the management of her household, always to her a matter of some difficulty, into younger hands. It was about this time that I used to go from time to time to Scroope House to play backgammon with her, and although I doubt if she ever quite clearly understood who I was, she was uncommonly quick with the dice and held firmly to " the rigour of the game." J. was then, as ever, an enthusiastic gardener, and most days in the week he managed to put in an hour or two after lunch in the beautiful garden lying between Scroope House and Coe Fen. He was successful with most plants because he understood and humoured them, but in particular he was successful with roses. It was one of his pleasures to send baskets of roses to his less happily situated friends in College. Not only could J. grow flowers, but when they were grown he could arrange them, and the floral display at Scroope House, and even the decorations of the dining table, were always arranged by him. As we have seen in the opening chapter, his mother was also a notable gardener, and in the matter of prizes at the local horticultural shows was unusually successful. To the end she took a keen interest in flowers, but by 1887 she was rapidly failing, and she died on the 8th November in that year.

For the past eleven years J. had been working at the 


\section{The Architectural History}

Architectural History of the University of Cambridge, which had already occupied his uncle's leisure for the last twentyone years of his life. I cannot now do better than quote some sentences from the Preface, dated 21st April 1886, in which J. described the genesis of the book :-

"The work ... originated in a lecture " On the Collegiate and other Buildings in Cambridge,' delivered by Professor Willis in the Senate House, on Wednesday, July 5,1854 , on the occasion of the visit of the Archæological Institute of Great Britain and Ireland to Cambridge.

"When I first examined the manuscript," J. continues, "it appeared to be much more nearly finished than it ultimately proved to be ; and I thought that my task would be limited to the verification of references, and the selection of subjects for illustration. I soon found, however, that I had fallen into a grievous error. At no college was the work quite finished; if the history of the buildings was complete, that of the site would be unfinished, or vice versâ. At King's College, for instance, the history of the chapel had hardly been begun, though that of the site had been carefully investigated; at St. John's College the entire history was unfinished, which was the more to be regretted, as it was known that Professor Willis had carefully watched the destruction of the old chapel in 1869, and had made notes upon it; while even at Trinity College, though the history of the site, and of King's Hall, had been written out at length, that of the buildings was by no means complete. . . Under these circumstances I came to the conclusion that in order to produce the work in a way which should be worthy alike of the author and of the University, it would be necessary to go back to the point from which he had himself started and investigate the whole subject afresh. . . . The necessity for this comprehensive and thorough research will, it is hoped, give a satisfactory explanation of the length of time, just eleven years, which has passed away since I began my work. I have read, and made extracts from, the entire series of bursars' account-books for every college in the University, besides studying the documents relating to the history of the sites, the Order-books, and all other sources of information to which I could obtain access, both 
at Cambridge and elsewhere. A similar labour has been required for the University buildings. These records, especially those of the fourteenth and fifteenth centuries, as for instance the accounts of King's Hall, and those of the Proctors of the University, are exceedingly difficult to read, and require a good deal of preliminary study before any extracts of value can be made from them. Severe as this labour has been, I cannot regret it; for these volumes supply a detailed record of the life of our ancestors, from which, as will be seen in the separate essays, a complete picture of their manners and customs at different periods can be derived. . . .

"In all my additions-and it will be seen that they extend to nearly two-thirds of the whole work in its present form-I have strictly confined myself within the limits which the author had traced for his own guidance; remembering at the same time that he proposed to write not merely ' the architectural' history, but 'the architectural and social' history; by which epithets I understand that the modifications introduced into collegiate structures by the changing habits of those who use them are always to be borne in mind and noticed."

The great work, and it is a very great work, was published in 1886. It is dedicated " To the memory of Henry Bradshaw," "the dear friend to whom I am under deeper obligation than I can put into words." It is J.'s chief monument. Parts of the following letter refer to the M.O. To make other parts clear, it should be mentioned that J. tried each year to have a day on the "sacred river," and that both his boys were now at Aysgarth, a preparatory school. Edward had been there for a year, but Willy went to school for the first time in September, and Mrs. J. accompanied them to settle him in :-

\section{Scroope House, 29 th August 1885.}

"What weather! The thermometer is down to $60^{\circ}$ in my study! and there is a bitter gale from the NE. which blows through everything, including my bones! It is perhaps as well I am not at Laleham to-day. The Sacred River in an east wind would be too disgusting. 


\section{F. and bis Children}

"My position about Aysgarth is just this. I should like to go, but at the same time I don't quite see how to spare the time; and I feel sure that if I do stick to work this next month I shall get the wretched thing (it has got to that now) finished. I am struggling with the "Changes in Style,' which is a bore; and after that the only really important piece of work is the Introduction."

\section{Scroope House,}

17 th September 1885.

"I never knew how fond I was of my children till I lose them. The day has been a sad blank to me, the house so silent and the consciousness that one will have to wait three months before one hears their merry voices again. It has made me feel, too, that one has closed a chapter in one's life, and that the babyhood of one's chicks is over, and that now one must bear to be separated from them for the greater part of their future life. It has all burst upon me of a sudden, being that I am prone to absorption in the Immortal Pub., and only descend to matters of real life at intervals. . . . I mean to work at nothing else but the Pub. for the next three or four days, in order to see what I can do towards breaking its back."

I would like here to say a word about J.'s affection for his family. He was, as all who knew him, devotedly attached to his friends, and showed his affection in a thousand ways, each of which cost him some effort, some trouble. He was also, in spite of a whimsical cynicism, intensely affectionate to his wife and children. He almost kept his boys at home when they should have been at school, and he was in later days never so happy as when in company with his grand-childrenindeed grand parents should have grand-children!

The first paragraph of the following letter refers to the Architectural History, the second to the projected Life of Adam Sedgwick, Professor of Geology, 1818 to 1873 :-

\section{Scroope House,} 3rd August 1886.

" Dear Dr. Jessopp, - I am glad to hear that you like the outward appearance of my book. I wonder what your 
real judgments will be when you have read it, for $I$ am afraid that your politeness may prevent you from pointing out the numerous defects, not to speak of downright mistakes, which I am conscious of in it. I hope that when you do find anything of either kind you will not hesitate to point it out to me. I am in hopes of a second edition being called for before I am too old to undertake one.

"With regard to Sedgwick, I should be glad of any stories you may be able to remember and kind enough to send me. The one you send now shall certainly be introduced into the life somewhere. It will not be difficult to give the dry chronology of his life and a more or less lucid account of its principal events; but I despair of being able to set forth the man as he was, with all his vigour of talk and action; his fun and his seriousness so strangely blended; his strong affections and his equally strong dislikes; and lastly, but by no means least, so much of his language will offend most sorely the ears of the present generation. . . Ever yours sincerely, J. W. CLARK."

The Architectural History was hardly published before J. was asked to collaborate with Professor Hughes in the Life of Adam Sedgwick. He threw himself into this task with characteristic vigour, visiting Sedbergh in September 1887 and again in August 1888, where he "wrote and worked with Miss Sedgwick." He also visited Dent and later Norwich, where Sedgwick had held a canonry. "Read Sedgwick's letters"; "Adam Sedgwick to dine; discussed MS. of Sedgwick's Life," were entries which now occur at intervals in his diary. On the 27th August 1888 : "Took first four chapters of my Life of Sedgwick, to be made up into pages"; two days later: "Reached Cromer at 12.39. Lunched with the Bishop of Norwich. He told me several stories about Sedgwick." The following day he "called on Archdeacon Neville, who lives in Sedgwick's house." Evidently the book was not to suffer for lack of local colour. However, its preparation had a long set-back, partly due to Mrs. J.'s illness. She was very unwell in the summer of 1888, and, though J. took her to Yorkshire for change of air, she was no 


\section{The Librarianship}

better in the autumn, and had to lead quite an invalid life for a time. In June 1889 we read: "Resumed work on Sedgwick, much interrupted of late by preparation for the Antiquarian Society." Eventually the book appeared in 1890, and was well received. No sooner had J. finished the Life and Letters of Adam Sedgrwick than he began another book. During a summer holiday with his family in Brittany he records that, on 18th August 1890, "I began to translate the "Augustinian Observances." These he finished on the 30th of the following month at Cannes, where he and his wife had gone to visit Dr. Henry Jackson and Mrs. Jackson. The translation, under the title of Observances in Use at the Augustinian Priory . . . at Barnwell, did not appear until 1897 owing to J.'s ill-health.

In the spring of 1889 Willy won an Open Scholarship at Eton. The news had been first and unofficially conveyed to the family by the Matron in College writing for his height that she might order his surplice. Edward was now at Harrow, where he entered in 1888.

In $1887 \mathrm{~J}$. had been a candidate for the Disney Professorship of Archæology but was not elected, and at the time felt his lack of success very keenly. Two years later he stood for the post of University Librarian and received a great deal of support, but in the end he retired from the contest. A former Librarian, the late Professor Mayor, wrote him the following letter-the last sentence shows that the Professor had a keen eye for character:-

Sr. JoHs's, 20th July 1889.

" My dear Clark,-I do not care to serve on a committee, but I have no hesitation in promising you my vote if you are nominated by the Council.

"There are few indeed who have rendered such ungrudging service of such high order, to the University, as you have done for many years. The chief work of a librarian I take to be to make his staff work, and I am confident that you will hold the reins with a firmer hand than they have been held with during my memory.-Very truly yours, "JoHn E. B. MaYor." 


\section{7. in bis Prime}

The following letter addressed to Sir Harry Wilson belongs to this period :-

\section{United University Chub, Pall Malu East, S.W., .5th July 1889.}

“ Dearest HaL, - It was very nice of you to write me such an affectionate letter. It gave me very great pleasure to receive it. I so often feel that my life has been a failure-that I have been weak when I ought to have been strong-that it is a comfort to me to be assured by anybody that I have been of use to them. Frank Balfour was the dearest friend I ever had or ever shall have, and since I lost him, you and J. J. L. have filled a blank space in my heart. I often wonder whether, if I had had brothers, I should have cared for them as I care for you two. I wish I could be of more use to young fellows at Cambridge. I have kept many straight, that I know by their own admissions, but I often reproach myself that I have not done more in that way. My natural shyness, which people won't believe in, has been the principal cause in many cases of my non-interference.

"If Frank had lived he would have stimulated me into scientific research; now that he has gone my only chance of handing my name down to a second generation of University men is to return to my first love-literature and library work -and that is the real reason why I am so anxious to obtain this post at the Library.

"We went to Eton to-day, and there found, to our great joy, that Willy had got the Junior Tomline mathematical prize, bracketed with another boy. Still his name stands first. That any son of mine should be distinguished in mathematics!-Ever yr. affectionate

"J. W. C."

It was perhaps fortunate that $J$. did not succeed in winning the Librarianship, for two years later another post, that of Registrary, became vacant. It was a post peculiarly suited to J.'s genius, and one in which he had already acted for four years as Deputy, and he was duly elected on 12th May 1891. He held the post until a few days before his death. 


\section{Elected Registrary}

The new appointment necessitated his resigning his two posts at the Museum, and this he did at the end of the year. I have dealt fully with these resignations in the two Appendices, and here I will content myself with quoting the letter written to him by Dr. Peile, the ther Vice-Chancellor-Dr. Peile never flattered:-

\section{Christ's College Lodge, Cambridge, 6 th November 1891.}

"My DEAR REgistrary, - I have received to-day notice of your intention to resign on 31st December 1891 the combined offices of the Superintendent of the Museums of Zoology and Comparative Anatomy, and of Secretary to the Museums and Lecture Rooms Syndicate-offices which you have held so long and with so much benefit to the University. I am writing no mere words of compliment when I say that we can never expect to obtain more zealous or more efficient service in either department.-Believe me to be, Very sincerely yours, John PeI.E, V.C." 


\section{CHA PTER VII I}

\section{J. AS REGISTRARY}

The year 1892 opened sadly for J. and his wife. Edward, their elder son, was very ill with pneumonia and pleurisy, and for weeks they were in a state of great anxiety, but his constitution was sound and he pulled through, and by the middle of March he was able to start with his parents for Madeira. On the 1st January I had succeeded J. in the post of Secretary to the Museums and Lecture Rooms Syndicate, and in spite of his anxiety about Edward, J. came almost daily to the Museums to instruct me in the accounts and to help in preparing for the annual audit.

The visit to Madeira was a great success; and Edward, at first carried about in the convenient hammocks of the island, was soon beginning to walk. For the time J.'s old interest in natural history returned, and he visited the fish-market before breakfast on most mornings, and in time got together quite a large number of species for the Museum; in fact before he left the island he had spent 21,585 reis on his collection of fishes. In the afternoons he often collected beetles, spiders, and other land forms; he also searched the rock-pools for littoral animals.

They had been met by Mr. Guillemard ${ }^{1}$ on their arrival in Funchal, and after a stay of a fortnight they were joined by Mrs. Wynne and her daughter (now Lady Lawrence, wife of Sir A. W. Lawrence, Bart.), two of their oldest and closest friends. Their names occur again and again in J.'s diary, and one remembers them as the most welcome of guests time after time at Scroope House. A little later Willy joined

1 Brother of J.'s friend, Dr. F. H. H. Guillemard of Trumpington. 


\section{Madeira}

the party, and he and J. made an excursion of three days to the northern side of the island. The insatiable activities of J.'s mind would not be satisfied by collecting specimens, and writing a very full diary and innumerable letters; he must learn Portuguese, and with this object in view took daily lessons. How far he got I don't know. He was all his life in the habit of bursting into French, but I have never known him burst into Portuguese. J., whose duties as Registrary had been carried on during his absence by Mr. C. E. Grant of King's College, left his family behind him and started for home on 3rd May. He reached Cambridge on 7th May, and immediately plunged into the preparations for the Installation of Spencer Compton, eighth Duke of Devonshire, as Chancellor, which duly took place on 11th June.

The office of Registrary was very congenial to J. It brought him into contact with a great number of people both old and young, and it permitted him to have a large share in the ordering of all ceremonies- "stage-managing" them, he called it, and the mere expression was to his mind fascinating. On these occasions he always made himself smart, wore a rose in his button-hole, and what he called his "jubilee" tie (for he had purchased it on the occasion of Queen Victoria's first Jubilee in 1887), and with his white hair and beard, walking half a step behind the Chancellor or the Vice-Chancellor, he was always a noticeable and picturesque feature in the procession.

The last half of this year J. was very unwell, suffering almost continuously from mysterious pains in the head, giddiness, and dizziness. He undoubtedly overdid himself physically in Madeira. He would take long walks, a rash thing to do in that relaxing climate. At times he was quite unable to work, a most unusual thing for him, and it was about this time that he handed over the editing of The Cambridge Natural History, which he had undertaken to bring out for Messrs. Macmillan, to Dr. Harmer and myself. He however never lost interest in the work, and was most kind in 
helping us in many ways. About Christmas time, 1892, Mr. Stanley Leathes of 'Trinity, now First Civil Service Commissioner, succeeded Mr. C. E. Grant as Assistant-Registrary. This Christmas too Charles Newton began the portrait which hangs in the A.D.C. Theatre. Early next year he was busy arranging for the memorial to his predecessor Dr. Luard, and drawing up the circular appealing for pecuniary help. The memorial took the form of printing certain of the University Grace-books.

By the spring of $1893 \mathrm{~J}$. had not been away from Cambridge except for an odd day or two for ten months, and now he thought his beloved Paris might do him good, so he and I started off for France on 14th March.

We saw a good deal of J.'s old Parisian friends Mr J. Reubell and his sister Miss Reubell; they were as always most hospitable, the former asking us to dine to meet the Whistlers. Another night we dined with Peter Studd and met Charles Rothenstein.

I have only one fragment of a letter from this time addressed to Mrs. J., but it shows that J.'s hand had not lost its cunning :-

Hôtel St. Romain, 27 th March 1893.

"... We called on M. Charles Yriarte, whose acquaintance Shipley had made at Cambridge. He's the man who writes the books on Venice, and César Borgia, and Lucrèce. $\mathrm{He}$ was perfectly charming. I don't know when I have passed so delightful an hour. He seems to have known all those naughty people, to have lived in their company, and only left them yesterday to return to-morrow. At present he is working at Isabella d'Este (of whom I have never heard)-she was sister-in-law to Lucrèce Borgia, and a great patroness of the arts. There are 500 letters of hers at Mantua, which this indomitable researcher has been copying. I could not talk to him about Lucrèce, for I could not for the life of me remember whether he had proved her guilty or innocent. I must find out before I see him again." 


\section{Fire at the Registry}

Unfortunately I had to leave in about a week, but my place was taken by Stanley Leathes, and J. stayed on another few days and visited innumerable theatres. On his return the entries in his diary about his ill-health almost cease for several weeks. In July he took a "cure" at Harrogate, but in spite of everything the pains in the head returned, and at times he was quite prostrate; it is painful to read on nine successive days of the diary the single word "headache."

On 8th of November the chimney of the Registry was found to be on fire, and this soon spread and the roof was burnt; the contents of the Registry were quickly moved to some rooms belonging to the Syndics of the Press. Three days later they were transferred to the old Library at Pembroke, and here for many months, by the kind hospitality of the College, J. carried on his business, until, under the advice of Professor (now Sir Alfred) Ewing and Mr. W. N. Shaw, the Registry was rebuilt and rendered fireproof.

Early in 1894 the sale of a portion of the allotments lying to the east of the present Botanic Garden, to the County authorities for the purpose of building a County School, was before the Senate. J. advocated the sale in a cogent fly-sheet, but the proposal, supported though it was by the Financial Board, was thrown out.

In the spring of this year $J$. varied his annual visit to Paris by returning through Holland, an unknown country to him. The following two letters to Mrs. J. date from this time. He was now resuming his researches into libraries, which lasted till his death.

Hôtel St. Romain, 8th April 1894.

"I am starting to-morrow at 8.20, and hope to reach the Hague at 5.54, and to meet Lionel ${ }^{1}$ at the station. I feel very shy and strange at trusting myself in a new country where I cannot speak a word of the language,

$1 \mathrm{Mr}$. Lionel Cust. 
and where I don't know a soul. Still I feel I must go, and that it is wiser to go now than to wait till Whitsuntide, when very probably I should be unable to go. I cannot tell what may turn up in the May Term.

"I have always liked the French, but never, never did I suppose it possible that so many persons, all strangers to me, would take so much interest in my pursuits, and give themselves so much trouble to serve me. . . . I have made two finds at the Bibliothèque Nationale; two at the Sorbonne; and one at the Arsenal. This last is the best of the lot, and I look forward to finding much that no one has yet seen in the illustrations to the MSS. in that library. They have a glorious collection-far finer than in the Bibliothèque Nationale. I have discovered all about the library of Citteaux, and the library of Clairvaux, and the library of the Sorbonne-which I shall use for my lecture: ${ }^{1}$ and I hope to get such photographs of Zutphen as will make good slides."

\section{Doelen Hotel, Amsterdam, 11 th April 1894.}

"I write a line to say that we have been to Zutphen to-day, and seen the chained library to great advantage. It is a most curious thing, to which no description that I have heard or read does justice. The cases are very rude and rough, and there is no beauty about it; but it gives one an excellent idea of what one of those old libraries must have looked like when the chaining system was in fashion. . . .

"Having done all we could there, we came to this place. I am delighted with all I have seen as yet, so wonderfully picturesque and full of colour, and nothing dull and formal about it. What surprises me so much in Holland is the bustle and activity of the people. I had expected to see Scotch formality and precision-I imagined the Dutch a nation of British Dissenters : but I find instead, a merry, pleasure-loving people, who look as if they had nothing to do but to amuse themselves all day long."

These letters show the great interest J. was then taking

1 The Rede Lecture, June 1894. 


\section{Libraries}

in the arrangement of libraries and the care of books. Amongst many other papers of antiquarian interest written about this time, are those "On Libraries at Cesena, Wells, Guildford, and Clare College, Cambridge"; on "The Guildford Grammar School Library"; "On Libraries at Christ Church, Canterbury, Cîteaux, Clairvaux, Zutphen, Enkhuizen"; and "On Libraries at Lincoln Cathedral, Westminster Abbey, St. Paul's Cathedral, London." Some of this material was used in his Rede Lecture, ${ }^{1}$ delivered in June of this year. This lecture, together with the substance of a short series which $J$. gave in 1900 as Sandars Reader in Bibliography, formed the basis of his remarkably successful work, The Care of Books. This was published in 1901; a second edition appeared the following year, and a third and cheaper re-issue in 1909.

To return to 1894, in August of that year J. and I made a most enjoyable tour in Eastern France. A French friend of his, a M. Cuinet, came with us, and added to our enjoyment. We stopped at Dijon and Besançon, and finally reached Jougue in the Juras, where we spent a week. We then went to have a view of the Lake of Geneva, with its background of Alps from the Col de la Faucille. Although the weather was atrocious, it was pleasing to see-when we could see-how the view was fully up to the standard of J.'s recollection of fortytwo years ago. ${ }^{2}$ We started back by way of St. Claude and Bourg, and after visiting Brou, to see the Church, we came back to Dijon to collect certain plans of Cîteaux which were being prepared there for J. Next we left for Semur and Avallon, and thence drove to Vezelay, a very glorious building on an unrivalled site. We returned by Auxerre, Sens, Troyes, and so, as J. would say, " home," i.e. to Paris. I never enjoyed a trip more-J., although far from well, was so intensely interested and interesting. There was in every town some plan or some library he wanted to see, and I soon found out that the French librarian and the French archivist are as interesting in the

1 "Libraries in the Mediæval and Renaissance Periods."

${ }^{2}$ See pp. 77-78 


\section{54 J. as Registrary}

flesh as they are in the pages of Anatole France. Here are some letters on the tour written from J. to his wife :-

\section{Hôtel des Bains, Besançon,} 28th August 1894.

". . . I have enjoyed being at Dijon very much, though the town has not much of antique appearance about it. Still it contains a good many interesting things, not the least of which are the plans of Cîteaux, which I had the good fortune to discover in the Archives de la Ville this morning. I went, as is my habit, to see the librarian, to whom I gave my lecture, and he was so charmed with me that he did everything he could to promote my researches. Among other things, he referred me to his confrère at the Archives. On Monday we made an expedition to see the site of Citteaux. It is always interesting to see where a building, so famous as the Abbey of Citeaux, once stood, but in this case there the importance or value of the journey ends.

"On getting here we found the faithful Paul Cuinet awaiting for us at the station. . . . His help has been valuable so far, for he advised us to come to this hotel, a delightfully fresh and clean house on the outskirts of the town, with a garden, baths, electric light, and, in a word, 'toutes les ressources de la civilisation moderne.' All these things are very comfortable and nice no doubt, but I can see that the old Provincial France is gone to join the other pleasant things of the past. . . Here, as with us, the government is falling into the hands of our deadliest enemies, the small shopkeepers, with the results that we are familar with."

\section{Hôtel Laferrière, Jougue (Doubs),} 31 st August 1894.

"We got here last night after a twelve hours' journey from Besançon. It was very tiring, though exceedingly beautiful, and I certainly felt that we were quite right to have taken it instead of the shorter one by the railway. We began by a short railway journey to a place called Lot, whence we were bundled in a little voiture to Mouthier, a large village, where we waited three hours for the diligence. . . Cuinet's uncle is the parish priest there, 
and he took me to see him. Instead of the usual curé de village, rather rougher and less cultivated than his parishioners, I found a delightful old man, very well-informed on all subjects, with views on the Irish question, etc. $\mathrm{He}$ lived in a quiet little house opposite his church, with a gay garden before his windows, and a collection of insects caught in the neighbourhood."

\section{Jovgue, \\ 3rd September 1894.}

“. . . This place needs the pen of a Sévigné-or some one else who had the art of spinning a letter out of nothing. Our life is singularly monotonous. We get up early-at least I do ${ }^{1}$-and have my coffee. Then we read or write a little till déjeûner at 12. In the afternoon we take a drive; at 7 we dine; and we go to bed at 10 , or even earlier. . . . The country round is charming, beautifully wooded, with wide tracts of pasture, and great bluffs of limestone. Twice we have got up high enough to see Switzerland. The view was not very clear, but there it was, and yesterday we saw the Lake of Geneva with Mt. Blanc beyond it. This was from the top of the Mont d'Or, an eminence $1600 \mathrm{ft}$. above the village. . . . Cuinet took me the other day to call on the curea delightful old thing. He might have sat for a portrait of Friar Tuck, and talked of nothing but the price of wine, and his own good fortune in securing a barrique of a certain Saint Emilion at some fabulously low price."

Col de ta Faucille,

Friday, 7 th September 1894.

"This is at the very top of the Jura, and I am delighted to find that the hotel is built within a few yards of the spot where I saw the view 42 years ago, which I have never forgotten, and which I still think is one of the finest to be seen anywhere. To-day it is all misty and hazy, but still there it is, with the wooded slope of the Jura for a foreground, the Lake of Geneva in the middle distance, and the Alps in the background. I do hope it will be clearer to-morrow. It is as cold as midwinter, which they say is a good sign."

1 I did not.-A. E. S. 
Hôtel de la Cloche, Dijon, 12 th September 1894.

"It is quite impossible to describe the Church of Brou. I had no idea of what I was going to see, but I certainly did not expect so large a church, or one so full of exquisite work of every kind, in the best style of the early Renaissance. ... In plan it is like a small cathedral, nave and aisles, transept, choir with aisles, all in a late Gothic (1502-1536). Eastward of the crossing is a richly carved rood-screen, through which you enter the choir, fitted with magnificent oak stalls, richly carved with saints and emblems. The apse has its original stained glass. In the centre of the choir, in front of the altar, is the great glory of the Church, the tomb of Philibert II. He lies at full length, carved out of white Italian marble, surrounded by weeping cherubs, on a slab of black marble, round which are exquisite figures of Saints and Sibyls in niches. Behind these, on another slab of black marble, is a second figure of him, as he might have been when dead. The face of the upper figure is turned towards the tomb of his wife, which is on the left, under the arch leading from the choir to the aisle."

Auxerre,

15 th September 1894.

“On Friday we made our great excursion to Vezelay. It is quite up to its reputation, and is certainly one of the most wonderful places to be seen in France. The little town, together with the church and the ground where the monastery once stood, occupy the summit of one of the isolated hills so common in this part of France, so it can be seen from a great distance. ... You walk up the steep street, and presently come out on the open space in front of the church. It (the church) is of great extent-I suppose about half the size of Ely, with a grand Romanesque nave, and a later choir, ending in an apse. All the stained glass is gone, and some years ago $M$. Viollet le Duc was let loose on the building, so most of it has been rebuilt, and everything that could tell us about its history has been carefully obliterated. In fact, it looks as new as it 


\section{Tour in France}

must have looked in St. Bernard's time. The monastic buildings, which are said to have contained 800 monks, were entirely swept away at the Revolution."

In the spring of the following year he was still hunting libraries in France, this time with Edward, and as usual writes almost daily to Mrs. J. :-

Hôtel n'Albion, Rouen, 5th April 1895.

"... We have taken a short preliminary walk about Rouen, and looked into the Cathedral, where the word BIBLIOTHECA on a door has greatly excited me. I am to go to-morrow to learn more about it-for by an absurd arrangement it seems to be shown only in the month of May. Why May? . . .

" 6 th April.-I have spent the day at the Bibliothèque and elsewhere hunting after information. Everybody was very civil to me: but I can't say that I have discovered much that is new, except the existence of a large and important Chapter Library, founded (like all the others) in the middle of the fifteenth century. I did not get behind the magic door, but I did get into the room above it, now used as a library. It contains some curious reliquaries and service books and other objects, but no bookcases of any age."

\section{Hôtel St. Romain, Paris,} 19 th April 1895.

"... The library of the Collège de Navarre has been pulled down, but I was shown two photographs of it, of which I hope to obtain copies. It must have been a most curious building, and worthy of all care to preserve it. Instead of this, they dragged it down for no other reason than that it was 'vieux.' It had survived the Revolution and the changes made in the building by Napoleon I, only to be destroyed by his soi-disant nephew. From this sad spectacle we went to the Lycée Henri Quatre, where Laurent was educated, and there, quite unexpectedly, I made a most interesting discovery. The buildings were originally those of the Couvent 


\section{58



St. Geneviève, and possessed a splendid library, built gradually at the top of the other rooms, as was usual. After the Revolution the books-or what remained of them-were removed to a new building, where they still are. But, now used as dormitories for the scholars of the Lycée, the old Library still exists, practically unaltered, with a great deal of the old panelling and ceiling-the dome with its decorations-and a Museum, quite unaltered, with the old glazed cupboards, put up about 1675. Laurent, who had spent a year in the building, had never seen this! It is quite the most curious thing I have yet come across, for, though comparatively modern in construction, it is a most instructive example of the way in which conventual libraries were arranged."

In the summer, J. lectured before the Archæological Institute at Scarborough about mediæval libraries, upon which he was becoming the expert. The following letter to Mrs. J. is particularly interesting on account of what he says of himself at the end of the final paragraph:-

Royal Hotel, Scarborough, Saturday, 20th July 1895.

"... We had a most delightful excursion yesterday to Beverley, which was entirely new to me. . . . It is a glorious building-I mean the Minster, with a grand Early English choir and transepts, and a Decorated nave ending in a Perpendicular west front. Inside there is the wonderful Percy shrine, or rather tomb, probably the finest piece of mediæval sculpture that has been spared to us. . . .

"My lecture went off very well last night. . . . The long-suffering persons I talked to sat patiently from 8.45 to 10.30 , and I think were really interested.

"I am glad to hear that my article on Owen ${ }^{1}$ is really out. I always feared that Kit ${ }^{2}$ might get frightened and leave it out altogether. ... I have never done any good in science since Frank Balfour died. If he had lived, I

1 In the Church Quarterly Review.

2 Christopher Knight Watson, the Editor. 


\section{His Political Views}

should probably have been egged on by him to take up some special line. I have now drifted, I hardly know how, into this Archæological track, and see my way to producing a little something which may be interesting to the world at large as well as to professed antiquaries."

J. was a Liberal in politics, but a tempered Liberal. I imagine the term "Gladstonian" would most nearly define him, though in some respects he was more Radical. I don't think he thought out political questions as he thought out subjects which commanded his interest. He was apt to vote on the impulse of the moment. $\mathrm{He}$ was in all cases more moved by men than measures. It is only fair, however, to record that he was most anxious to vote Liberal in January 1910 , and, when his doctor forbade him to go out of doors, characteristically remarked, "That's what comes of having a Tory for one's doctor." He held strong views on taxation, and a new tax imposed by either party met with the most vigorous condemnation expressed in the strongest language. What he would have said had he lived until to-day, passes imagination. He did not, however, take any very active part in the political world. He had other things to attend to-important things. In University politics he was a wholehearted reformer, and he took a leading share in many of the changes which have modified the University since the time of the last Commission. As we have seen in a letter from Professor Newton, he was consistently in favour of the abolition of the Heads of Houses, ${ }^{1}$ though I never could see that the poor dears do much harm. He welcomed the establishment of new Triposes and new avenues to Degrees. He strongly approved the introduction of new subjects, such as Engineering, Agriculture, the study of Heredity, the Diplomas in Tropical Medicine and Forestry, and many other innovations.

Without being very deeply interested in the question, he was in favour of granting degrees to women. Early in 1896 he goes to a party "of the friends of the Woman Movement" 


\section{$160 \quad$ 7. as Registrary}

at Christ's Lodge, and on 16th March he records that the proposed appointment of a Syndicate to prepare "a scheme for females degrees" was thrown out by 186 to 171 , chiefly on the ground that it did not adequately represent the divergent opinions of members of the Senate. But the matter did not rest there-a second Syndicate was appointed on 4th June of the same year. They reported on 23rd February 1897, and the Report was discussed on 13th March, the discussions occupying sixty-six pages of the Reporter. There seemed at first some chance of their proposals being carried, when, on 17th May, J., with the then President of Queens', the then Master of Gonville and Caius, and the Senior Tutor of Clare issued a fly-sheet, "On Degrees for Women," from which I quote the last three sentences:-

"Our opinion that it is desirable to grant to women who are successful in our Tripos examinations some such distinction as that recommended by the Syndicate has undergone no change, but the opposition which the Report has called forth has compelled us to look at the question from an entirely different point of view.

"We are forced to ask ourselves whether an extension of privilege to women students ought to be granted at all unless supported by a majority both of resident and of non-resident members of the Senate, such as that by which the grace for admitting women to University examinations was passed in 1881. The removal of a grievance which, after all, has pressed upon a comparatively small number of persons, can be bought at too high a price when considerably more than half of the resident members of the Senate are known to be bitterly opposed to the measure, and would view it, if carried, as a grave betrayal of trust. A victory under such conditions as these would be worse than a defeat. The passing of the Graces would, in our opinion, prove injurious to the best interests of the University; while the benefit conferred upon those for whom we are risking so much would be of doubtful value. They would find the University hostile instead of friendly. 


\section{Degrees for Women}

"We hope before long for a solution of the problems with which the Syndicate has had to deal, in which the Universities of Oxford and Cambridge may act together."

The effect of this fly-sheet was widely felt. It "stampeded" a number of waverers, and when the vote was taken on 21st May 1897 , the proposals were thrown out by between two and three to one.

At Easter, 1896, J. and Willy made a short tour in France, haunting libraries. They visited Amiens, Noyon, Laon, Rheims, Senlis, and, of course, Paris, and J. writes home:-

Rheims, 1 st April 1896.

"I have made a great discovery here-two most important libraries : one belonging to the Jesuits, fitted up in 1678, and now used as the lingerie of the Hôpital Général; the other that of St. Rémi, fitted up about a century later, and now used as the Chapel of the Hotel Dieu. The wood-work in both is as perfect as the day it was put up, and quite splendid of its kind-that of the Jesuits especially."

An entry in J.'s diary reminds me that in this year I nearly got into serious trouble by opening a little Exhibition of pictures in the Bijou Theatre, now the Gymnasium next door to Messrs. Barclay's Bank, which the Bank-directors had most kindly lent me. I had no idea that if you held an exhibition and took money at the door you must have the leave of the town authorities, and we were open half a day before I was warned. However, the Mayor, whom I at once sought, was very kind, and gave me the required permit on the spot. The pictures we exhibited are probably quite out of date now, but in 1896 they were, to us poor provincials, startlingly new. They produced on us at that time the sort of impression the paulo-post-impressionists produce on the layman at the present day. In my extremity I had engaged an underworked publican with the mien of a prize-fighter 
to collect the shillings. He had told me he was strictly honest, later I doubted the truth of his statement. He sat close to a stove near the exit reading the Sportsman, and when the amazed visitors, having inspected the pictures in the outer room, made for the open air, he forced them back, indicating the inner room with a jerk of his thumb, and saying, "There're worse "uns inside." It is rather a relief to me that while both J. and Mrs. J. visited the Exhibition, they have not put on record what they thought of the pictures.

J. was still haunting libraries, spending some days in August in the neighbourhood of Hereford, and then going on to Canterbury to stop with his old friend Canon A. J. Mason.

In a letter to Mr. C. E. Sayle, he says :-

"I propose to go through the buildings seriatim, Willis in hand, and if I am to see anything I had need stick tight to him, for successive Deans have improved off the face of the earth many interesting features since he wrote. I ventured to suggest to Mason that we ought to add a new petition to the Liturgy: 'From all Deans and Architects, Good Lord deliver us!' Really it is a wonder that anything has survived.

"We've had a delightful time in and near Herefordweather not bad-always something interesting to see on hand. From Monday till to-day we were with Lady Lyttelton near Ross-a wonderful place, with a view that delighted even me. I am always tempted to say with the old Frenchman, 'Aimez vous les grandes vues de la Nature? Pour moi, je les abhorre.'"

In the spring of 1897, Willy, to J.'s great delight, won a Major Scholarship at Trinity. A few days later J. and Mrs. J. started for Paris, where they were joined later by Mr. and Mrs. Lionel Cust and Edward. They had a delightful holiday, and did a round of theatres.

For a considerable period before the time we have now reached - the end of 1897 - the name of Mr. T. D. Atkinson has constantly occurred in J.'s diary as being frequently at Scroope House, and in 1897 the result of their conferences appeared in 


\section{7. as a Lecturer}

the form of that interesting book, Cambridge Described and Illustrated. But the following year J. made an even greater hit in his Concise Guide to the Town and University of Cambridge. This has already gone through four large editions, the last being that of 1910. The Guide-book, one of the most successful of its kind, is arranged in four walks round the town.

J. usually gave a popular lecture or two each year. For instance in 1898 he lectured on Mediæval Libraries at Hereford, and again at Preston, and a little later at Barnwell on the Abbey Buildings. J.'s matter was always excellent, well thought out and well arranged, his diagrams were most ingenious and his slides most instructive, yet somehow he was not a great lecturer on formal occasions. Both as a speaker and as a lecturer there was something missing in his delivery. He stuck too close to his manuscript. He carefully prepared his speeches, but for some reason or another, though you agreed with his argument, his rhetoric left you cold. In his lectures I think he attempted too much; they often lasted an hour and a half or an hour and three-quarters, and he would attempt to throw on the screen as many as seventy lantern slides. Where he was at his best was in making short, terse speeches, or in taking a small company round Cambridge and from time to time delivering little impromptu addresses upon the buildings. In this connexion the following amusing entry appears in Mrs. J.'s diary: “The Working Men's College came to Cambridge for the day and $J$. gave them a lecture in Downing Grounds before they started sight-seeing. This figured in the programme of the day as 'Bread and Cheese, and Mr. Clark's Lecture'!"

J. was always willing to place his unrivalled knowledge of College buildings at the disposal of his friends, and when Queens' College in 1898 celebrated the four hundred and fiftieth anniversary of its foundation, he drew up a beautifully illustrated account of the history of the College and its buildings for the use of those attending the ceremony. 


\section{F. as Registrary}

In August of the same year the fourth meeting of the International Congress of Zoology was held in Cambridge, and J., who had an unrivalled experience in managing Congresses, took an active part in the preparations for this one. $\mathrm{He}$ had as his guests his old friend Professor Milne-Edwards, the Baron de Guerne, and M. Schlumberger.

J. always had a high sense of the dignity of his office as Registrary, a dignity of which some of the undergraduates were ignorant. They sometimes entered the Registry in a cloth cap, and sometimes with a cigarette between their lips. They never did it twice. On one occasion when a gentleman of colour was behaving in an unusually fidgeting way, J. suddenly burst out, "I'll have you understand, Sir, that you are in the Registry of the University of Cambridge and not dancing about outside your mother's wigwam." Freshmen at Matriculation were often his despair. He used to say that most of them could not write, while of the remainder some did not even know their full Christian names, while others, who were better informed on this point, did not know how to spell them. Here, however, as always, J. welcomed the genuine inquirer, and he was especially pleased by one undergraduate who said to him, "Before signing my name in your book, sir, I should like to know to what it commits me. I promised my father never to sign any document without first understanding it." In November 1898, Lord Kitchener, recently returned from his campaign against the Mahdi, received an honorary degree. After the ceremony the behaviour of the undergraduates was not such as to impress the Sirdar. J. took the matter up, and next week in the Cambridge Review he let certain of the younger members of the University know what was thought of their behaviour on this occasion.

One thing J. enjoyed doing as Registrary was exercising a little private patronage in the way of granting tickets for the various functions in which the University from time to time indulges. He was particularly thoughtful about the widows of Professors and of others connected with the University. These 


\section{Silver Wedding}

ladies' names, not being on any of the lists of University residents, are apt to be overlooked, and he took especial care that they should not be forgotten. At the celebration in honour of Sir George Stokes in the summer of 1899, J. asked him how many tickets he would require, and Sir George, who was the most learned and the most modest of men, said "he supposed he must have one for himself, and, if it could be spared, he should like one for Lady Stokes."

The 9th December 1898 was the silver wedding of J. and Mrs. J., but owing to the Trinity Commemoration the celebration was postponed for one day, as the following letters show. On the 10th they sat down sixteen to dinner, and "the Master of Magdalene ${ }^{1}$ proposed our health in a charming speech."

\section{J. to H. A. Neroton.}

Scroope House, Cambridge, 9th November 1898.

"Dear Harry, -We are going to celebrate our Silver Wedding on the 9th December-that is to say, that is the actual day on which the happy event ought to be commemorated, but we find we have run against the Trinity College Commemoration, so we shall hold the formal dinner, which is de rigueur on those occasions, on Saturday the 10th. We hope you will stay with us from Saturday to Monday, or Friday to Monday, if you can manage it.Ever your affectionate, J. W. ClarK."

\section{Beaufort Gardens, S.W., 9th November 1898.}

"Dear J.,-I shall be too delighted. I am afraid I cannot now say whether I can come on the Friday, but Saturday, December 10, is booked, irrevocably booked, that I may wish my dear J. and his dear wife long life and continued happiness, such as I believe they have enjoyed to my personal knowledge for eighteen years.

1 The Reverend and Honourable Latimer Neville, afterwards the sixth Lord Braybrooke. 
"It is very kind indeed of you to ask me on such an occasion to celebrate a 'run' of such a length! What, I should like to know, has Trinity to commemorate in comparison?

"Did Trinity restore order to the finances of the A.D.C.? Has 'Irinity given the real blessings of a home to generations of undergraduates? No. Trinity has achieved a certain prestige from its Heads, and from the manufacture of Dons, but Scroope House has triumphantly flourished as the Home of Hearts and the Shrine of the Drama.-Ever yours,

H. A. Newton."

Early in January 1899, Willy having passed the Home and Indian Civil Service Examination accepted a post in the Board of Trade. He had previously been offered the Admiralty and the Civil Service Commission. Edward, who was threatened with lung trouble, was passing the winter at Davos under the care of Dr. Edward Henry Douty, late of King's College, an intimate friend of J. and his family, and towards the end of March, J., accompanied by one of his closest friends, Reggie Balfour, set out to see him and to tour in Italy. His companion left him after a day or two at Paris, but rejoined him later at Assisi. After spending a week at Davos, the quiet of which J. found very delightful, he left for Rome. The following letters to his wife tell of his doings:-

Hôtel de Londres, Rone, 8th April 1899.

"I spent yesterday afternoon with Father Ehrle, ${ }^{1}$ who was kindness itself, and explained many things to me that I had not fully taken in before. I am to meet him again this morning at 10 A.M., and as the Library is shut, I shall have him to myself all day."

Hôtel de Londres, Rome, 10 th April 1899.

"I would not lead the life the -_'s lead for $£ 10,000$ a year. No quiet, no real pleasure, no means of acquiring

1 Librarian at the Vatican. 
knowledge about the place, or realising its beauties-merely a dull round of card-leaving and saying pretty things to people you don't care about, and who don't care about you.

"I have had a great triumph to-day. You will remember that I said that the Vatican fittings put up by Sixtus IV must have been like those of Cesena. A short while since, while some repairs were being made in the Ospedale di Santo Spirito, which he founded, they came on some frescoes under the whitewash. One of these shows Sixtus in the middle of his library, with the bookcases and two readers seated at them. They are exactly like those at Cesena. There's an undesigned coincidence!"

On 9th April he dined with Monsignor, now Bishop, Stanley and met the Heads of the English, Scotch, and Irish Colleges :-

"Their conversation might have suited the library of Sixtus IV. They talked of what they allowed their pupils to read, what newspapers were permitted in their colleges, etc. It seems that a very strict censorship is enforced; and these sucking priests may only read certain prints, and not all of those. At last the spirit of mischief made me utter an impassioned defence of L'Assommoir, which made them sit up a bit."

In the spring of 1900 he again went to Rome, where his brother-in-law, Sir George Bonham, was then First Secretary of Embassy, accompanied by Willy. I add some extracts from his letters to Mrs. J. while in Italy :-

Orvieto, Easter Day, 15 th April 1900.

"Willy will have told you what we did up to Siena. We spent Good Friday there very peacefully, and found an English service of a sort. It was held in a building which called itself the Waldensian Church, and from its internal arrangement that community appears to differ but slightly from the Presbyterians of your country. There was a portico in the Classic style in front, through which you passed into an oblong room with a small semi- 
circle at the end of it. Into this was squeezed a piece of furniture which looked like the back of a piano, and was, I suppose, a pulpit; and in front of it again was a small deal table (the altar?). For the English service these things were not disturbed, but it was said from a second deal table, set somewhat to the side."

Roмe, 20th April 1900.

"I am now writing a very brief letter, chiefly because I shall not be able to write to-morrow. I am going all by myself to see Fossa Nuova, a Cistercian Monastery which is said to have been never altered. It is only sixty miles from Rome; but I have to start at 7 A.M., and shall not get back till 8.50 P.M.! It is situated in the Neapolitan territory near Terracina. I am in hopes of doing the excursion with something approaching to comfort, as I have obtained a permesso to go over the building (of which the Government has taken possession); and Prince Borghese (who owns an estate in the neighbourhood) has written to his agent to show me some civility.

"After lunch, Louisa ${ }^{1}$.. . lent us the carriage to go to S. Peter's again, where I was to meet Father Ehrle. That dear person took us a long but delightful walk through the Pope's private garden, and thence into the court of the palace, which is not often seen. The private garden is never shown to strangers. It might be made very beautiful, but the Pope is so nervous that the trees have been encouraged to grow up and shut out the view. I was much edified by his taste in polyanthuses-now just coming into flower. Ehrle and I had a long talk about my researches, and he was most kind and encouraging.

"There is a short but sympathetic article in a periodical called Kunst Cronik, by Professor Steinmann of the German Archæological School here. I wish I knew how to get at that nation. I believe they would appreciate my work more than the English are likely to do. I have now quite made up my mind that I will make no further new researches, but write the book ${ }^{2}$ and have done with it.

1 His sister-in-law, Lady Bonham.

${ }^{2}$ The Care of Books. It appeared in 1901. 


\section{Libraries at $\mathcal{P}$ aris}

It ought not to take me long, having regard to what is in print already; and when it is once out, I may be able to get fresh information and bring out a new edition before I die."

J. spent some of the first days of this century in Paris, working in the daytime and play-going in the evening:-

\section{Paris, 9th January 1901.}

"I spent yesterday with Jacques, ${ }^{1}$ both lunching and dining there. In the interval I went to the Bibliothèque Mazarine, where I found, after some difficulty, a book I wanted much to see-a commentary on the Rule of a certain Congrégation de la Sainte Croix. M. Franklin had quoted a long extract from what he called the Rule, which was very interesting from the Library point of view; but I had my doubts. I now find he was quoting the Commentary and calling it the Rule! So down goes that idol. I am such a vieux respectable that he actually lent me the book, and it lies on my table at this moment.

“'To-day I went down to the Bibliothèque de l'Arsenal and had a long talk with my excellent friend M. Henri Martin, librarian. 'There I smashed another idol-a supposed private chained library. It turns out that the good man left it to his native place, Pistoia, and that the city chained it in 1460 - two years after he died-a very natural and proper precaution."

On the 10th April 1901, Edward married Miss Lilian Milman, eldest daughter of the late Sir Archibald Milman, K.C.B., Clerk of the House of Commons. J. and his wife were very happy over this wedding. After Mrs. J.'s death, Mrs. Edward did everything in the world to care for him, and he was never happy when she was away.

The following July, J. spent a week-end at Wenlock Abbey, one of Mr. Milnes-Gaskell's places. Evidently he thoroughly enjoyed his visit :-

1 M. Jacques Reubell. 
Wenlock Abbey, Much Wenlock, Shropshire, Sunday, 21st July 1901.

"One is quite out of the world here; but I don't long for pavement-at least not yet. In fact the charm of this strange weird house-so unlike anything I have ever seen elsewhere-has not worn off as yet. We live in the open air-all doors and windows wide-and both nights we have dined out of doors-last night on the grass where once the cloister was. It must be this that has done me so much good that I feel a different creature. Both nights I have slept as sound as many tops.

"Need I add that I am entirely at Lady Catherine's ${ }^{1}$ feet. She is a really cultivated and thoroughly agreeable woman, who writes plays, and very good ones too. Fortunately for me this is their place of rest to which they retire from a rat-castle near Wakefield, where he is Chairman of the County Council, and she has to open bridges and say good-bye to Volunteers, and the like. So I have them to myself, and most thoroughly am I enjoying it. In fact I am strangely and completely fascinated by a life that is quite new to me."

\section{Wenlock Abbey, Much Wenlock, Shropshire, $22 n d$ July 1901.}

"I have completed my plan of the curious little library building here, and flatter myself that it is rather a sweet thing. I have done it at my leisure, without interruptions. There is never any interrupting here except what they make for themselves."

From Wenlock Abbey he went on to Falconhurst, the country house of Mr. J. G. Talbot, then Member for Oxford University, the father of J.'s great friend Eustace, and here on the 29th July he was thrown out of a dog-cart and broke his right arm. The fracture was a serious one, and it was long before he regained the use of his arm.

In the two following letters he reports progress to Mrs. J., who was away from home for a few days :-

1 Lady Catherine Milnes-Gaskell. 


\section{F. breaks bis Arm I7 I \\ Scroope House, Cambridge, 24 th October 1901.}

"As for myself, I am getting on very well, and I can lift my arm with comparative ease, straight up and down; but any attempt to bend the fingers, or turn the wrist, still causes violent pain. However, this pain diminishes in hot water, so it must be taken as muscular. I am now wearing only one sling instead of two, and I want to get leave to discard the sling at night. . . .

"I hope that you" have received all the letters I have sent on to you. You must be amused with the different hands in which they are directed; I employ anybody who may happen to be at hand."

Scroope House,

27 th October 1901.

" I $^{1}$ am sitting at J.'s table, and he is being massaged, and he tells me to write as follows. First, that Miss Rogers $^{2}$ says the arm is distinctly better, and going on splendidly. He says it hurts being massaged-she says it doesn't. Next, I am to tell you that J. is bearing your absence with philosophy; last night he had the children and de Bunsen to dine. . . . The book ${ }^{3}$ is really published now, and I have seen it! Miss R. can rub all his tingers without hurting, so she says, but he groans and says 'ai'-but the fingers are getting straight."

The following letters deal with the proposal that J. should write the architectural history of Windsor Castle:-

\section{Lionel Cust to J.}

Oliphant House, Windsor, 28 th October 1901.

"The King has been here at the Castle to-day, and I had luncheon with His Majesty and a few others, including Holmes of the Library. During luncheon the conversation turned upon the history of Windsor Castle,

1 Dictated to Dr. G. W. Prothero.

2 The Masseuse.

${ }^{3}$ The Care of Books. 
and the various notes and information collected by Holmes and by Canon Dalton. I then informed the King that you had a few years ago been commissioned by Queen Victoria to prepare an architectural history of the Castle, and that you had been in communication with Bishop Davidson and Canon Dalton upon the subject. The King was very much interested to hear this, and spoke most kindly, even warmly, of you personally. His Majesty went on to say that he would be very much gratified if you could undertake this work, and desired me to communicate with Canon Dalton upon the subject, immediately upon his return with the Duke of York next Saturday.

"I think it better for you to let me know first whether you are willing and able, or not, to undertake the work. I hope that you will, now that your great Library book ${ }^{1}$ is off the stocks. The best way will be for you to write me such a letter as I can show to the King. I am, of course, quite ignorant what the scheme was which was approved by Queen Victoria, but this you will no doubt explain to me in the said letter."

\section{J. to Lionel Cust}

11 th November 1901.

"Your letter in which you mention the kind way in which the King was pleased to speak of me has given me very sincere pleasure, and I must ask you to take an early opportunity of conveying my humble duty to His Majesty, and of assuring him that I will do everything in my power to obey His Majesty's commands.

"It is not quite accurate to say that I was commissioned by Queen Victoria to undertake this work. What really happened was this. Canon Dalton suggested to me in 1890 that I should do for Windsor Castle what I had done for the Colleges of Cambridge, and Dr. Davidsonthen Dean-talked the matter over with me. In the following year Canon Dalton asked me by letter (July 30) whether I would really undertake the work, as the Queen was anxious to have it done. This letter was succeeded by one from Dr. Davidson, then Bishop of Rochester, to 
Canon Dalton (August 17), stating that the matter had been mentioned by him to the Queen, with my willingness to undertake it, and that Her Majesty had been graciously pleased to say that she would be glad if the work could 'really be put on the stocks at once.' In subsequent letters I was assured that every facility would be given to me for examining the buildings, and for studying their records. Further, I learnt in conversation with the Bishop that certain drawings prepared for the Prince Consort might be used in the book.

"At that time I fully intended to attack the work at once, and began the study of the subject; but at the end of the year my eldest son became seriously ill. In the spring of 1892 I had to take him to Madeira, and when I came home my own health gave way, and for about two years I was not allowed to do any work except the most indispensable. I had promised to lecture on Windsor before the Archæological Institute in 1893, but I could not do so, and my friend, Mr. St. J. Hope, took my place. I believe that he has since continued and developed the history which he then sketched, and, having regard to his known ability in dealing with ancient buildings, I should be glad if his co-operation could be secured.

"I am afraid that this letter is running to an inordinate length; but I wish to explain how it happened that I failed to comply with the very flattering invitation made to me ten years ago.

"The King will doubtless wish to consider what sort of book His Majesty would like to have written. In 1891 I was told that a single volume after the manner of Stanley's Memorials of Westminster was desired, but for a building which has gone through so many changes as Windsor Castle, more ground plans and illustrations than are used in that work would be necessary. These, however, are details on which I need not say more at present.

"I need only add in conclusion that I will do all in my power to carry out the wishes of the King so soon as I thoroughly understand what sort of book is wanted. I feel tolerably certain that the Cambridge University Press will gladly produce it, but I am unable to state at present on what terms." 


\section{The Reverend Canon Dalton to J.}

\section{The Cloisters, Windsor Castue, 24 th November 1901.}

"My dear Mr. Clark,-Sir Dighton Probyn tells me that it is the King's wish that I should write a few lines to let you know that when His Majesty fell in with a suggestion made by Mr. Lionel Cust that you should undertake the composition of an Architectural History of Windsor Castle, His Majesty was unaware (as was also Mr. Cust) that Mr. St. John Hope had been at work upon the same for nearly ten years, and ever since your unfortunate illness. There have also been placed at $\mathrm{Mr}$. Hope's disposal, by the late Queen Victoria's permission, all Parker's MS. and the woodblocks which were cut by the Prince Consort's orders to illustrate such work, together with photographs of buildings now destroyed, and plans and drawings of excavations which he and I have made here since 1893, especially of Henry III's Great Hall and other works, the existence of which had never before been identified in detail. Mr. Hope has also put together, on lines of his own development, a large mass of material gathered from original and contemporary authorities.

"Under these circumstances the King feels that it is only due to Mr. Hope to let his work go forward independently. His Majesty deeply appreciates the readiness with which you were good enough to respond to the suggestion that you should undertake such a heavy and arduous piece of labour as would be entailed upon you by the composition of such a work, but it appears now unnecessary to trouble you to proceed further with it. Might I, however, be allowed to ask whether you would be disposed to consider favourably the possibility of your adding a 'narrative' or historical introduction to the book? By this means your name might still be associated with a work that I know has always lain near your heart. Would you be able to meet, and talk this over with Hope? You know, I am sure, that his reverence and affection for you would prompt him to heartily welcome such a thing if agreeable to yourself.-Believe me, dear Mr. Clark, yours very sincerely,

J. N. Dalton." 


\section{University Library $\quad$ I75}

At the time of J.'s death Mr. Hope was still at work on the History, and J. had thus no opportunity of contributing the historical introduction.

Throughout $1901 \mathrm{~J}$. was actively supporting the proposals of the Library Syndicate to roof in the Eastern Court of the Library, and to arrange immediately under the roof a spacious reading-room, and under this again a store for books in two floors. The reading-room was to be surrounded by a double wall of books, the bookshelves facing outwards being reached by a light iron gallery. This gallery would afford a convenient means of communication between the adjacent rooms of the library and the reading-room and book-store. The architect estimated that the book-store, with the outer shelves of the reading-room, would hold 117,000 volumes, and the readingroom 12,000 more; these latter would be chiefly works of reference. J. had this matter very much at heart, and in October 1901 he issued a most elaborate pamphlet, in which he sketched the history of the Library, and advocated the proposed enclosure of the Eastern Court. The pamphlet was illustrated with plans, elevations, and sections.

He was intensely vexed when the Syndicate's proposals were non-placeted by nineteen votes, and he did not conceal his vexation. In fact ever afterwards he divided Members of the Senate into two classes, those who voted "for" and "against" the Library. For instance, shortly afterwards a Member of the Senate, who had voted non-placet, called on J. at the Registry to consult him on an antiquarian point. He wanted information about the Whitgift Almshouses. Now this gentleman had an impediment in his speech and therefore could not pronounce the troublesome word Whitgift very plainly, and J., though he understood perfectly what was wanted, affected to believe that he was asking some question about Wycliffe. "I know," he cried, "I know what you want to find out about Wycliffe. Very interesting point! I will look it up and write to you; I am rather busy now." With that he pushed his inquirer, who still vainly tried to articulate the word Whitgift, 
towards the door, opened it and got rid of him. Then turning triumphantly to his Assistant Registrary J. said, "That'll teach him to vote against the Library."

There are almost no entries in J.'s diary for 1902. In the spring he was interesting himself in raising a fund to pay off a considerable debt which had been incurred in buying a site for and building the Clergy 'Iraining School in Jesus Lane. In this the committee, with which J. was working, were only partially successful.

In the summer, as Registrary, he attended at Westminster Abbey the ceremony of the deferred Coronation of King Edward VII, and thus describes the great solemnity :-

\section{United University Club, Pall Mall East, S.W., 9th August 1902.}

"The Coronation was a wonderful sight even from my place in the nave. As a spectacle-a display of colour-I have never seen its like, nor could I have imagined so brilliant an effect. It is usual to say of such things that they recalled a parterre, but in this case a flower-bed was not in it. Nothing in nature could equal the brilliant display of uniforms and ladies' dresses, all of the brightest, newest, and most glittering. Our seats were very good, for nave seats, and we could see well into the annexe, and up into the quire, but all the important parts of the service were lost to us, and the music so poor and ineffective that they were not marked by any striking passages. I need hardly say that ' Zadok the Priest' played everything else off the stage. The British aristocracy, after having been shut up in a cupboard for about half a century, bore the dusting and shaking and burnishing very well, and it was great fun watching the peeresses 'peacocking' in, with their trains, along the gorgeous carpet. The King looked extraordinarily well-much thinner, but brown and hearty - and seemed really to enjoy his reception. There was a great outburst of cheering as he passed down the nave. The Queen looked terribly worn, and she had to sign to the Bishop of Oxford to take her hand. We got into the Abbey at 8 A.M., and left it at a quarter to 3, so we had enough of it. I don't know when I have been so tired." 


\section{Belgrade}

J. was much gratified early in October to receive from the University of Oxford the offer of an honorary Litt.D. degree, which was conferred upon him on the 9 th of that month.

As usual, he spent some of the early days of the new year in visiting his friends at Paris, and at the beginning of April started off with Mr. H. J. Edwards of Peterhouse for the Near East. The first stop was at Belgrade, to visit his brother-in-law, Sir George Bonham, our Minister at the Servian Court. They went on to Constantinople, where J. was received by his old friend, Sir Henry Babington Smith, then President of the Ottoman Debt. They came home by Athens, Corinth, Patras, and Brindisi, but the following letters to Mrs. J. tell their story :-

\section{British Legation, Belgrade, 6th April 1903.}

"It's an awful place. The two girls have just taken us for a walk to see the fortress, and the view, which is wonderful, as the building, or what is left of it, stands on a promontory at the junction of the Save and the Danube. Unfortunately the day is dull, with an east wind; in fact just such a day as one would have if one went to Ely, and the view not unlike that from the Cathedral tower, except that the Danube is a trifle wider than the Cam! All this is interesting enough; but the town, as I said, is awful. It reminds me rather of those unfinished towns in Algeria, about which the French guide-book was so eloquent. The streets are wide, but paved with huge stones laid anyhow, so that you jolt to and fro when you drive; and you can pick your way when you walk, as if you were crossing a stream on stepping-stones. The houses are generally in two floors only, but in the streets that are called principal they are loftier. All, however, have a woebegone, starved look, as though they had once been better off. I don't suppose the place ever was different to what it is, but it looks as if it had gone to seed.

"The house is very nice indeed-the drawing-room quite charming. The Bolognese furniture is all a great success; especially one wonderful settee, with quite a high back returned along the ends, and gilt. It is a marvel, and impressed me so much that I dreamt about it ! 
"By the way, if I had arrived a day sooner, I should have come in for an émeute. Yesterday, being Sunday, and therefore a holiday, some students got up a riot against an unpopular journalist, and broke windows and burnt copies of the offending paper, etc. Part of it was just opposite the windows of this house, so the wrecking of the office could be easily witnessed. Then the troops were called out, and they fired, and killed a few people, and then it began to rain (fortunately), and so everybody went home. The spring here is very backward; but while the trees are not showing leaf, the lilacs are in flower. There's an untidy spot called a public garden, but destitute of flowers-no spring bulbs-no primroses-nothing but a few flowering shrubs."

\section{Constantinopie,}

\section{Wednesday Morning, 8th April 1903.}

"The scenery from Belgrade to Constantinople was very interesting, in so far as it gave one some slight idea of an important fragment of the earth's surface-to wit, Bulgaria. It is very like some parts of England, with ample pasture grounds and a few cornfields; and everywhere the said pastures seem to be well stocked with sheep, tended by a pair of huge dogs and a shepherd clad in skins, with the hair turned in and the leather turned out.

"Last night I went to bed very early in order to ensure being up when we got in sight of Constantinople. First the railway reached the sea, which, after the manner of the sunny South whenever I visit it, looked cold and grey. The coast is there very low, and no trees. Plenty of wading birds-tall storks and ducks. Then came a quantity of miserable, tumble-down Turkish villas; and, at last, these were succeeded by the old walls, wonderfully well preserved, seeing all that they have had to endure. Then came more green fields and large gardens, just as there used to be within the walls of Rome, and still are, as you may remember, between the Aventine and the Lateran."

\section{Constantinople,} 10th April 1903.

“. . . This wonderful place grows on one every hour. I have never seen anything like it. No description gives 


\section{Constantinople}

the slightest idea of it, and I think that most of what has been written fails of the mark, or deals with the time before European influence was what it is now. ... The streets are my chief delight. Such a crowd, and composed of such strange elements. The almost total absence of ladies or women of the lower orders even; everybody in a fez or a turban or some unusual head-gear; the curious objects of traffic-carts drawn by buffaloes, heavily laden mules, men with enormous burdens on their heads, and all talking and shouting at once-make an ensemble of the strangest description.

"Of course I have been to see Santa Sophia. I went in with a thrill, and the first impression does not wear off. It is a singularly solemn and dignified building, which looks much larger than it is. The central square is only $207 \mathrm{ft}$. square, about two-thirds of the length of King's Chapel. The Turks have not damaged it at all, and a very few hours would suffice to restore it to Christian worship. . . . The real mischief was done by the Crusaders in 1203. I did not know this before, and I strongly suspect that Byron ${ }^{1}$ confused the Turkish Conquest of 1453 with the Venetian piracy of 1203, when that old thief Dandolo took the city and sacked the churches!

"We are going to-day to see the Sultan go to his mosque! Hal thinks this a suitable occupation for Good Friday-I think it doubtful. However, the exception may be allowed."

"The ceremony of the Selamlik is very splendid and curious. We visitors took our places at about 11.30 on a terrace overlooking the road down which the Sultan drives to the Mosque, which was directly opposite to where we stood. . . Gradually squadron after squadron of the Turkish army marched up-splendid-looking men, in smart, clean uniforms-until about 15,000 had been got together, lining the road and blocking every avenue leading up to the palace and mosque. (Hal was much edified with their bearing, and thought they would take a good deal of beating, as I am afraid they will.) Punctually at twelve the muezzin mounted the minaret

1 "Oh for one hour of blind old Dandolo!

Th' octogenarian chief, Byzantium's conquering foe."

-Childe Harold, Canto iv. Stanza 12. 
of the mosque and called the faithful to their prayers, and immediately afterwards the Sultan appeared in an open carriage drawn by two horses. We saw him very well as he came slowly down the hill-a pale, carewornlooking creature in uniform, with a fez, not a turban. ... The service took about half an hour; and on leaving the mosque he entered another and smaller carriage, which he drove himself, the servants preceding on foot, and the court running after. ...

"As a sample of the feeling with which the Sultan is regarded by the better class of his unfortunate subjects, here is what a Turk, high in office, said to H. B.: "D'habitude je ne bois pas, mais le jour que ce coquin crevera, je me griserai comme un polonais. ..."

Constantinople, 12th April 1903.

"Yesterday we went with H. B. to Stamboul, to hunt for a curious old Byzantine Church called the Saviour Pantocrator (=All-powerful), near which is an octagonal building said to have been once the library attached to the Church. I am sure I don't know whether it was, but it is a curious place. 'Then we went to the great Mosque of Sultan Mahmoud-the Conqueror - the man who took Constantinople in 1453, a magnificent building, a good deal larger than Santa Sophia, with a very complex and effective system of lighting. Hundreds of small lamps, in shape like one of my big claret-glasses, are suspended from rods, at a height of not more than 10 or 12 feet from the ground. The effect must be very marvellous when they are lighted-the floor a blaze of light, and the upper part of the church all gloom. But what is most curious of all is the great fore-court with a cloister all round, and a fountain in the centre, with a cypress at each angle, for all the world like Santa Maria degli Angeli at Rome; and behind it is a second court, without a cloister, but arranged as a garden, with tombs. In the centre is a special building called a Turbêh, in which Sultan Mahmoud reposes in a huge sarcophagus, with a gigantic taper at each angle, just like a bier in a Roman Catholic church. I wonder which religion borrowed from the other. I am rather excited about the fore-court, for as Santa Sophia had one (which served as 
a model for all the others), and as it was built in A.D. 532 by Justinian, it seems to me very probable that our builders took the idea of a cloister fiom the East, as they did the pointed arch, and other matters.

"13th April.-Yesterday afternoon Henry took us to see the old walls of the city on the land side. They were built by Theodosius and other emperors, and are in a wonderful state of completeness when we reflect on their antiquity."

Hôtei d'Angleterre, Athens, 18 th April 1903.

"6. . The Parthenon, ruinous as it is, is indescribably lovely, especially when seen in such a glorious atmosphere, and with the cloudless sunshine we had yesterday. To-day we have a scirocco of great violence which brings with it clouds of dust. The dust is such a pest here, that they have two men stationed at the door of the hotel with large plumeaux in their hands, who dust the visitor when he comes in."

On his return to Cambridge J. was confronted with a Report of the Council on "The List of Benefactors in the Commemoration Service." He criticised this report in the Arts Schools in rather a merciless way. He began, as he loved to do, with the history of the whole thing; he considered under various headings "the persons to be commemorated"; he pointed out some really extraordinary omissions in the revised list, and commented upon the retention of names entirely unconnected with the University. In fact he thought the list, as Talleyrand thought a certain lady's dress, "commence trop tard et finit trop tôt."

In the following year, 1904, I came up after the Christmas vacation on 12th January to find a note from J. on my table saying that our common friend J. S. Budgett was lying in his lodgings very ill with black water fever. Budgett had returned two or three months before from the Congo, having after several years' work and innumerable journeys at last solved the problem of the development of the strange fish Polypterus. He was alone in his rooms, and until his people could come J. had taken 


\section{F. as Registrary}

command and had seen that he was well nursed and cared for. His writing to tell me was just typical of his thought for others. On the 12th January Lord Braybrooke, Master of Magdalene College, died, and his family, as everyone in trouble seemed to do, at once sent for J. "Busy all day looking after them and Budgett. Overtired and much knocked up at night," is the entry for this day. Budgett ${ }^{1}$ died on 19th January, and J. "spent most of the day in talking to his family and arranging for a funeral service in Trinity Chapel."

This spring, on a bitterly cold day, 1st March, King Edward and his Queen and the Princess Victoria visited Cambridge to open certain of the recently finished Science Schools and the Squire Law Library. The arrangements for this visit took up much time, but J. threw himself into them with his accustomed vigour, and the visit went off well. In connexion with it $J$. wrote a learned article on previous Royal Visits to Cambridge, which appeared in the Cambridge Reviere.

From time to time J. as Registrary had to edit new editions of the Statutes and the Ordinances; these he seemed to enjoy doing, though largely they were matters of scissors and paste. The most important work of this kind that he produced was that on the "Endowments of the University," a mine of carefully sifted and valuable information; this he prepared in the spring of 1904. This year he also wrote his Concise Guide to Ely Cathedral and a number of other shorter papers. In August the British Association met at Cambridge and $J$. had as his guests M. Yves Guyot, Sir William and Lady Abney, and his old friends Mr. and Mrs. Maudslay. On the third day of the Meeting he gave an afternoon lecture at the Theatre on "The Origin and Growth of the University of Cambridge."

'This period was a sad one for J. He had an extraordinary genius for cultivating the friendship of the young, and he knew the way to the heart of a boy. Little more than a year after

${ }^{1}$ I have written a short Memoir of him, which prefixes his "Collected Papers." 


\section{His roung Friends}

his friend Budgett's death came a telegram to say that William Bennett Pike, ${ }^{1}$ whom J. had known from infancy, and who was a great friend of both Edward and Willy, had been drowned in the Mediterranean. At the end of May came the news that Eustace Talbot had died after an operation. Eustace was one of J.'s dearest friends and was beloved by all who knew him. Without making any great mark as a medical student at Cambridge he had always done well. In the social world of the University he held a high and an honourable position, and since he had been at St. Bartholomew's Hospital he had acquired a notable knowledge of diagnosis. Without doubt had he lived he would have made a great physician.

The following is a kind letter written in 1905 by J. to a young friend who had failed to take a first class in one part of a Tripos:-

"My DEAR G.,-I hope you are not disappointed at your place in the Tripos. Having regard to the severity of the examination, I think it is a very good one; and if you should be troubled with any regrets, let me add a crumb of comfort. The benefit of a University education is by no means confined to what a man gets out of books. They are splendid things no doubt, and the study of the past has its advantages; but for anyone who is to occupy a public place in the world (and a clergyman is one of those) a knowledge of men is even more important. So I think that a man who can make the best of both worldsthe past and the present-who goes into many societies, and takes part in many things that are going forward and claiming the interest of his contemporaries, leaves Cambridge a better man than one who has been a student and nothing else. So if you should look at the first class regretfully, think over what I have said, which is my firm conviction based upon a long experience, and not merely invented for the sake of making myself pleasant to you." Ever your affectionate friend, J. W. Clark."

All this year J. was unusually busy; he had taken up a campaign in favour of the University Library, and was writing,

${ }^{1}$ Shortly before J.'s death Willy married his widow. 


\section{F. as Registrary}

with his own hands, two or three letters a day to friends and old members of the University, appealing for funds. He was extraordinarily successful, and in five years got together nearly $\mathfrak{L 2 0}^{2} 000$. This year also he wrote numerous articles, and now began to contribute to Country Life, to which he sent some ten beautifully illustrated descriptions of colleges or libraries. He was also preparing an edition of Loggan's Cantabrigia Illustrata, issued by Messrs. Bowes \& Bowes in 1905.

Throughout the spring and summer J. had been constantly ailing; the old pains in the head and dizziness had reappeared, and there is constant reference to them in the diary. In spite of this he was able to lecture in August twice to the Library Association, once in and on the Chapel of King's College, and again on "The Evolution of the Bookcase." Shortly after these lectures were over, he started, under orders from his doctors, for Royat, accompanied again by H. J. Edwards of Peterhouse. As usual we have a series of vivid letters to his wife :-

10 th September 1905.

"Things are going on much as usual. We had a pouring torrent of water on Wednesday night and Thursday morning, but yesterday was a real fine day, and $\mathrm{Hal}$ and I went to Orcival-a pretty village in a fold of the hills nearer Mont Dore than to this place. It was a long drive of three hours, with a pair of horses. I got a dispensation from one glass of water, as the whole affair took from 10 to 6 . But it was well worth the trouble. The whole country was extremely beautiful, the road commanding views of all the extinct volcanoes of these parts, and Orcival itself is in a most picturesque situation, almost hidden amongst the hills, so that you are not aware of its existence till you are close to it. The church is magnificent-quite a little cathedral-about 150 feet long - with nave and aisles, transepts, and choir raised on a crypt. This choir has four apses, a most unusual number. The whole is in a pure Romanesque style, dated about 1150 I should think; it is in excellent preservation, and has never been restored (happy church!)." 


\section{La Chaise Dieu}

Le Puy, 17th September 1905.

"'The one piece of luck has been the visit to La Chaise Dieu. The morning began, as usual, with rain and a thick mist, but it lifted all of a sudden, and we really saw the place to great advantage, even getting the view from the battlements outside very thoroughly. It's a wonderful place, and I am delighted to have seen it, though of course it has a woebegone, departed-grandeur sort of air. ... But still, enough is left to make one realise what a huge Benedictine monastery in a remote situation must have been-with its fortified enceinte, its lofty tower of observation, and gate of entrance protected by an adjoining turret with loopholes in it. Then there is the library, intact, over part of the cloister, which tells me some things that I did not know before about the way in which these fifteenthcentury monastic libraries were built and cared for."

Early in 1906 J. was working with his friend Mr. A. T. Bartholomew of Peterhouse on a Hand-list of the Works of Richard Bentley, which was printed for private circulation. This was followed in 1908 by a larger work on the same subject, published by Messrs. Bowes \& Bowes.

J. paid his annual Easter visit to Paris, accompanied this time by Willy, and later they went on to Venice. Mrs. J. had had a serious attack of influenza in March and was slow in recovering. As the following letters show, J. was anxious about his wife's health, and indeed he found her, when he hurried back, ill in bed with pleurisy, looking "worse than I have ever seen her." 'The recovery was but slow :-

Venice, 21st April 1906.

"I was indeed relieved to get your letter this morning dated the 18th, for I was beginning to imagine all sorts of horrors. I think you will do well to stay at home and be careful, though I had been thinking that the seaside would be the best thing for you. However, Le père propose, et les medecins disposent-nothing goes straight.

"I have already told you what a perfectly lovely day yesterday was. I was too tired to stir out early, so went in a gondola to call on Mme. W. and make arrangements. She was at déjeuner-so I just saw her only and 
arranged for a meeting between five and six. Charming woman, 50-55, très instruite. After my déjeuner (where they tried to make me eat rognons sautés followed by rumpsteak, but failed) I wandered about the piazza, looked into St. Mark's, and so forth. Then I took ship and went to the Edens where I saw the famous garden. It occupies about two acres, I should think, on the Giudecca with a view out to Chioggia. Such a wealth of greenery and colour. All sorts of things flowering together that we only see separately. A bank of cinerarias, freesias, ixias, arums, and in the borders blue irises, tulips, narcissi, \&c. \&c. The borders seem to be edged with Madonna lilies with no sign of disease."

Venice, 22nd April 1906.

"The people here are delightful. I have completely won over to my interest the librarian, Signor Frati, and he offered to-day to take me into the old library, where we penetrated on the occasion of our last visit. 'To-morrow morning at 9 A.M. I am to meet the architect of the new building, and if I fail to get out of him a copy of his plan for the roof, ${ }^{1}$ my name is not what it is ! I am also allowed to do what I please in the library in the way of copying documents, so that I hope to have materials for a pretty lecture. . . I I always turn the Latin races round my little finger.

"You ask about the Campanile. I can't be quite sure what my feelings are. Personally I never cared much about the building, except the squat obelisk at the top, which had a strangely picturesque effect. But somehow without it the square looks odd-St. Mark's so much larger than formerly, the huge mass of the Campanile being absent.

J. returned early in May, and for the months of July and August they took a house at Woking for the sake of Mrs. J.'s health, and Mrs. Edward Clark went with them to look after her. In August J. was again ordered away to Royat, where Willy joined him. Here are a few letters from there :-

1 The Marciana Library had recently been removed from the Ducal Palace to the Zecca, and the court-yard of the Zecca had been roofed in so as to form a reading-room, somewhat after the plan which J. had advocated for the University Library at Cambridge (see p. 175). On his return J. lectured on the Marciana. This lecture was printed in 1911 by the Cambridge Antiquarian Society. 
Royat, 30th August 1906.

". . . I am going through a course of Anatole France. 'La Grèce s'abrutit,' I said to myself. 'You know nothing about contemporary French literature.' So I have read Le Mannequin d'Osier, which I don't care much about, and am now deep in L'Orme du Mail, which is charming."

\section{J. to A. T. Bartholomere.}

\section{0 th August 1906.}

"I am very glad you are so happy in your Cornish exile. I can imagine Ovid's feelings in Pontus, pauvre cher homme, and I suspect mine in Cornwall would not be very different. I wish I did care more for wild places. I used to do so; and when I was your age I travelled in Norway (when it was a very rough, wild country) with great delight. So enjoy it while you can. I confess that even now I'd like to see a good rough sea beating over the Tintagel coast, for a short time.

"31st August. . . . You must know that in these parts we are either Gauls or Romans. Vercingetorix had his camp at Gergovie close by, and he is duly commemorated everywhere. To return to myself. At 9 I take a bath of warm water-Eau Eugénie, to commemorate the Empress, I suppose. 'This is mildly warm-and it is a bain coulant, that is to say, the water goes on running, so that it does not get chilly. Déjeuner at 11.30 , and very ready one is for it I can assure you. After déjeuner I do various things. I sometimes stroll ; or go into Clermont Ferrand, where there are shops and public buildings and picturesque streets; or sit in my room and work. At 4.30 Eau César again, and at 5.30 Eau Saint Mart. Who this Saint was I leave to the Provost ${ }^{1}$ and other hagiologues to say. ' Il me fait l'air d'un soldat Romain' (Martius). At 6.30 we dine, and then we go to bed. The interval may be filled up variously. You can smoke in the garden, or gamble (Petits chevaux or Baccarat), or listen to a band which I am told plays out of tune, or go to the Theatre, which is not bad at all. I have been twice.

"Besides all this, or worked in among it, I do some work. I am finishing this dreadful Barnwell 2 by making

1 i.e. of Kings, Dr. M. R. James.

2 The Liber Memorandorum. 
a first draft of the Index. When that is done, more articles ${ }^{1}$ must be written. In fact I have not a moment to call my own."

\section{J. to C. Sayle.}

\section{Hôtel Continental, Royat-les-Bayns, P.D.D., 9th September 1906.}

"I rather envy your being within reach of Munich. It is the one German capital I really like. Dresden is too full of English, and Berlin is impossible. But I thought the theatre, or rather the Opera, was the principal object of interest there. Don't you rise to the Ring? If you have never heard it, take my advice and don't miss it. It's worth living on bread and water for six months to save money for such an experience, and I have only heard a scratch performance of it in London, where Brunhild's steed was a seedy cab-horse, who funked the fire. At Munich they have, or used to have, a dear beast who knew his cues quite well, and walked straight into the fire as if it was his stall. That is art!

"Somebody ought to edit the catalogue of Perne's Library. You, I fancy, gave up the task, but why not resume it? . . . It is my rooted conviction that everybody has time for everything if they choose, i.e. if they take a real interest in what they are asked to undertake.

"I am deep in Anatole France, whom I had not read before. I have now read L'Orme du Mail and Crinque Bille, and an reading Monsieur Bergeret à Paris, which is delightful, though not suitable for families. I have Le Crime de Sylvestre Bonnard in reserve, and will buy the two you have recommended when I get to Paris. I don't quite know how to define the charm which he unquestionably possesses. He does not draw character particularly well, but he seems to me to be quite excellent in the way of reproducing in dialogue a past phase of opinion, or a national craze. Hence, he is so good about IAffaire; and the plot in Félix Faure's time to restore the monarchy. I wish I had L'Anneau d'Améthyste here to complete the Bergeret series. I have it at home, but I have only read a few chapters of it."

1 For Country Life. 


\section{J. to Mrs. J.}

Vicux, 14th September 1906.

"The place is quite lovely. I had never seen a French watering-place of the first class before. It strikes me as a sort of fairyland, as I said on my post-card, a combination of nature and art to provide an exquisite resting-place for the sick and those who fancy themselves so. There's a river with a broad quay along its banks (constructed by Napoleon III), whence you get lovely views of the distant hills; and a nouveau parc, all greenery and coolness. Then there is the vieux parc, a grove of trees planted close together so as to shelter les malades from the sun. It is beautifully kept, with an abundance of seats. . . . Lastly, there's the old town, a quaint little place on a hill, with the church where Mme. de Sévigné said her prayers, and the house where she resided in 1676 and 1677 (according to a plaque on the outside). Etta $^{1}$ says she wrote several charming letters from here recording her impressions, and among other things the extraordinary fact that she bought a pair of fowls for two sous!"

\section{J. to C. Sayle.}

Scroope House, 20 th September 1906.

"I have never read Balzac's Béatrix. To my mind his best work (of those I have read) is Une ténébreuse Affaire. At present I am going quite crazy over L'île Inconnue, by Pierre de Coulevain-the best and most generous criticism of England that has yet been written.

"I am utterly amazed at your cool indifference about Nürnberg. Why, even to walk along the streets is a joy. I have been there four or five times, and I could go forty or fifty without satiety. I wish the place had smelt of anything so wholesome as kümmel while I was there! My memory recalls Byron's lines :-

'With human gore that column was cemented, With human filth that column is defiled!"' 
On his return J. found that his wife's health had not improved, and it was now decided that Edward and his wife and family should come and live at Scroope House. This necessitated an enlargement of the house, which was carried out without delay. He did not always see eye to eye with his ground-landlords; I imagine few tenants do, but I think none but he would have in cold blood carefully arranged the letters that passed between them, neatly tied them up in a bundle, and endorsed them "Correspondence with those Brigands the Master and Fellows of — College."

On the first day of November, J. met with a serious accident in London. Seeking to avoid a motor omnibus, he got into the way of a hansom cab, was knocked down and much injured, and had to remain in bed for some days, fighting his doctors and nurse. He was picked up by a policeman, and being much shaken asked the custodian of the peace to hold him tight by the arm and lead him to his hotel, which was only a few hundred yards away. When they had gone a little distance the policeman stopped and said to J., "I think it would be better, sir, if instead of my holding your arm, you were to hold mine: it would remove from the public mind any apprehension that you are under arrest" - a remark which elicited from J. the characteristic reply, "Don't be a damned fool, I don't the least care about appearances; what I want to do is to get back to my hotel." The following letter, written after J.'s accident in London, gives some account of the number of injuries he received:-

\section{Scroope House, Cambridge,} 5th November 1906.

"Dear G.,-I shall be delighted to see you at any time. I am getting over my injuries as quick as I can, and am fighting with my doctor about the amount of rest which it is necessary to take.

"I have two black eyes, a broken nose, a bruise on my neck, and injuries to my left knee and another to my right foot. These injuries make me hideous to behold and very 


\section{Sidmouth}

cross. It is such a nuisance to be tied to bed when you want to be moving about.-Always your affectionate, "J. W. Clark."

It was decided this autumn that Mrs. J. must winter on the south coast, and in October a furnished house, "Norton Garth," was taken at Sidmouth, and the new year opens there :-

$$
\text { J. to C. Sayle. }
$$

5th January 1907.

"Here we are, all united at last. My wife joined me to-night at 5.38-terribly exhausted with her long journey, but not more so, I hope and trust, than was inevitable. The place seems suitable, being quiet and sunny, and we like our house. I have submitted it to a drastic treatment, having turned the best bedroom into a drawingroom, and the drawing-room into my wife's bedroom, and abolished, or put out of sight, all I could that belonged to the rooms in their primitive condition. The drawingroom looks really nice now that I have dressed it out with a certain amount of cut flowers. And I have discovered une fleuriste française; elle est charmante, et, sans doute, elle me fera dépenser pas mal d'argent, mais j'aurai toujours de quoi canser. You, who hate the Latin races in general, and the French in particular, will not see the charm of all this."

The sunshine and quiet at Sidmouth gradually restored Mrs. J. to a certain measure of health. J. was bustling to and fro between the Devonshire watering-place and Cambridge, and seemed little the worse for his journeys. In January he lost two close friends, Professor Maitland, who had sympathised with and aided his archæological researches, and Sir Michael Foster, whose advent as Praelector in Physiology at Trinity College in June 1870, he had ardently welcomed, and whose path as the introducer of the new learning he had ever sought to smooth. Till quite recently-when his strength was failing-seldom a Sunday afternoon passed with- 
out his making the pilgrimage to the shrine at Shelford (the Fosters' home), "Michael's Mount" as his friends were fond of calling it; the fact that he had in a measure given up his work in the Natural Sciences by no means weakened his affection for the Fosters, who knew that at Scroope House they had a Cambridge home. For many years they had always dined there on Christmas Day, whilst $J$. and his wife were the guests of the Fosters at Shelford annually on 8th March, Sir Michael's birthday.

Another old friend, with whom J. had been closely associated for over forty years, Alfred Newton, died in June. Each of them occasionally spoke a little sharply of the other, but in their hearts they respected and loved each other, and, whilst the Professor was able to get so far, there were few who more frequently called at Scroope House, and J. to the end paid continual visits to the Old Lodge at Magdalene College. In July, too, he heard the news of Reggie Balfour's death. He was a young man of high ability and character and of singular charm, who during the four years he spent at Cambridge made Scroope House his home. Of all the young men whom I know that J. and Mrs. J. befriended and helped, Eustace Talbot and Reggie Balfour were, I think, the most dear to them. Now both were dead.

This year appeared the Liber Memorandorum Ecclesie de Bernewelle, to which J.'s friend, the late Professor Maitland, contributed an Introduction.

By the middle of May the family was back at Scroope House; but Mrs. J. was still very weak, and could walk but short distances. In August and September, J. made his usual cure at Royat. Until his arrival at Royat the diary has no entries, or almost no entries, about his own health; during the preceding months he was probably too anxious about his wife's state in the earlier part of the year, but in the summer the headaches and the dizziness reappear in the diary. Edward and his wife joined him at Royat, and travelled home with him, visiting the Châteaux on the Loire en route. He was in very 


\section{Royat}

good health, and his letters to Mrs. J. from France are more than usually interesting:-

Hôter St. Romain, Paris, 21 st August 1907.

"I had a pleasant enough journey yesterday. I found the Dean of Westminster ${ }^{i}$ on board, and I spent the time in talking to him. $\mathrm{He}$ is always entertaining, and was specially so yesterday, in discoursing of the wonderful wealth of 'Obedientiary Rolls' which he has found in the Abbey. There are about 5000 of them! The Abbey seems to have taken possession of him, and he is working steadily at its history."

\section{Hôtel Continental, Royat-Les-Bains, P.D.D., $23 r d$ August 1907.}

"... I am fascinated with a book I bought in Paris on Etta's recommendation, Julie de l'Espinasse, by the Marquis de Ségur. It is long since I read so charming a picture of a whole society, with Julie as the central figure. I suppose the Marquis is a relative, perhaps the grandson, of the Vicomte de Ségur who was an intimate friend of Napoleon, and wrote his Memoirs. Anyhow, being what he is, he writes delightful French, not the argot now prevailing, and also has had the entrée to all sorts of family papers, out of which he has composed, for the first time, the real history of Mlle. de l'Espinasse. Moreover, he knows how to use his documents. He is a born historian. I am proposing to send the book to you as soon as I have finished it. I read 200 pages in the train yesterday, not skippingly, but every word, and some sentences twice.

"What a wonderful society it was! It is difficult to understand how the same people met every day from $6-9$, and often again at supper, and yet found something new to say: and when they did not meet they wrote to each other. That was the work of the morning. They dined at 2, rapidly, evidently it was a sort of lunch (my style), then went out, but returned in good time for the daily reception. I remember reading somewhere that

${ }^{1}$ Dr. Armitage Robinson, now Dean of Wells. 
Talleyrand told Lady Holland that those who had not lived in salons before the Revolution did not know what conversation was, but I should like to know what they talked about."

\section{Hôtel Continental, \\ Royat-Les-Bains, P.D.D., 24 th August 1907.}

". . . Yesterday the longing for a real good pavement seized me (Mlle. de l'Espinasse never went into the country if she could help it), and I went over to Clermont. . . .

"I am still deep in Mlle. de l'Espinasse, and as much under the charm of the book and the lady as ever. I fear that the work I brought with me won't get done. The lady, pauvre cher ange, does not improve in character or style as one goes on. After a long life spent in the exercise of all the virtues, she fell completely under the dominion of a clever scamp, who used her for his own advancement and amusement, and broke her heart. So the comedy tourne au tragique."

\section{Hôtel Continental, Royat-Les-Bains, P.D.D., 26 th August 1907.}

"Now for yesterday. We had a most delightful day with the Von Hügels, much enhanced by the strangeness and novelty of their surroundings. They have established themselves in the Inn at Pontgibaud, a little town of 900 inhabitants about 30 kilometres off. The said Inn is not too uncomfortable, and the food (à la française) excellent. It is on a high road, and what with the automobiles and the railway, they are full of business. One day last week they cooked sixty-five dinners! I felt that I had never understand v. $\mathbf{H}$. before. One forgets that he is an Austrian, and not an Englishman. Here he is completely in his element, chattering with everybody, knowing all about them, discussing their private affairs--their joys and their sorrows-with the priests and the old women, patronising the local hairdresser and collecting curiosities. He has taken up keys which apparently offer a ground of research not as yet exploité par les autres; and he has bought a perfectly priceless bowl of Samian ware (so called) for a morceau de pain, as they say here. . . . Pontgibaud 


\section{Royat}

not being primitive enough, the v. H's. are going on Wednesday to a still smaller village, where they have found two rooms in a newly built house. He took us to see the place. I confess that I had rather he lived in them than I! But the people seemed nice, and I had a good deal of fun with an ancient dame about les vipères which abound in those parts. B. $^{1}$ and $I$ are to spend next Sunday with them (not the vipers) there. I shall be curious to see what happens."

\section{Hôtel Continental, \\ Royat-les-Bains, P.D.D., 28 th August 1907.}

"I got your dear letter of the 26th last night, of all curious times. One of the vagaries, I suppose, of the British Post. I am going off this afternoon to Clermont to send you Mlle. de l'Espinasse. I am sure you will like it as much as I did, though the end is inexpressibly sad, quite a tragedy. The Marquis, however, treats it with a main de maître, and the whole book is thoroughly delightful and interesting."

Royat, 29th August 1907.

"I sent off to you yesterday Mlle. de IEspinasse, which I hope will reach you safely, and that you will enjoy it as much as I did. I have now got a second book of his, Le Royaume de la Rue St. Honoré, which is quite as interesting in its way as the other. It would really be more instructive to read it first, because it deals with just a single salon, that of Mme. Geoffrin, and explains the arrangement of it, what the habitués did, how conversation was kept in order, etc., etc. So it is really a far more valuable work (historically) for those who take an interest in the literary history of France than the other, though the supreme human interest of Mlle. de LEspinasse is wanting. Mme. Geoffrin was a jolly old soul, very rich and very good-natured, who gave good dinners (twice a week), and filled her salon with all manner of well-known and amusing people. But she was never in love in her life, and did not probably know what it meant, except that she had seen its disastrous effects on other people, her friends."

${ }^{1}$ Egerton Brandt, his doctor at Royat. 


\section{Hôter Continental, \\ Royat-Les-Bains, P.D.D., 3rd September 1907.}

"I am much amused at your account of our dear grandchild, 1 and her reluctance to go away. I wonder why babies are so fond of digging. What ancestral chord does it touch? I have seen our baby try to dig a hole in the gravel with a trowel. It seems certain that our remotest ancestors were arboreal; but I suppose they knew how to grub in the earth for roots.

"Now about yesterday.

"The Château Barante stands on a gentle eminence, charmingly wooded, with a fine view of the Puy de Dôme across the plain of La Limagne. Round the house is a park, so called, rather rough, and no garden to speak of, only a few formal beds, all ablaze with scarlet geraniums, which look well against the green trees as a foreground.

"The Château is said to be 300 years old, and perhaps parts of the walls may be, but it has been remanié so completely that it does not proclaim its antiquity. The whole ground floor is devoted to reception rooms. You enter a large stone hall, tout nu, no carpets, no chairs, only four busts on pedestals-Voltaire, Mme. de Staël, and two ancestors-and on the walls a few portraits. Then you pass left through a smaller room, which has some fine old cabinets and some priceless oriental china, into the drawing-room, which (divided into two of unequal size), occupies the whole of the east side of the Château. This room is really lovely. You'd have had a fit over it-white, with yellow curtains and yellow furniture, except a few chairs, of white wood, et brodées par mon arrière grandmère, said Mlle. de Barante. They found them in a lumber room. The whole room is Empire, in honour of a lady in Empire dress, who hangs over one of the fire-places. Furniture is again conspicuous by its absence. From this room you pass into the library, which occupies the whole south front of the Château, and evidently is used as a sitting room; for, as the day went on, the ladies all drifted into one of the rooms into which it is divided, and settled into some arm-chairs near the window, to enjoy the view.

1 Edward's eldest daughter, Valentine, born 1906. 
The books are so numerous that there is a gallery round the rooms, or rather round two of them, and there may well be 30,000 volumes or even more. The west wing contains the dining-room, which is not specially large. I suppose this part of the house contains also the offices, and it certainly contains the staircase leading to the upper floors.

"After déjeûner I was taken into the library, where for hours I had M. le Baron to myself; and it was a great pleasure to me to talk the native language as hard as I could go on my favourite subject, with so very sympathetic a listener. I can't say that I got any very special information about La Chaise Dieu, but I am sure I did get some about other things, and it is delightful to have made the acquaintance of such a charming person. He is anglomane jusqu'au bout des ongles, and I believe can speak English if he chooses. The family consists of Mme. la Baronne, her mother, the daughter, at whose feet I am, a young English lady who is a sort of companion and secretary, and is evidently expected to know where everything is. I took a great fancy to Madame. She is thoroughly friendly and pleasant. I suspect that she was a great heiress, and has replenished the family coffers, for when I admired two magnificent potiches of la famille rose, and asked if they were not porcelaines de famille, the Baron said no, they were a present from his father-in-law at the christening of one of the children. He added they were worth 40,000 francs then. It occurred to me that a man must be fairly well off who could afford to lock up $£ 1600$ in two vases to give away. . . .

"I forgot to mention that there is also a great collection of letters in the house, a perfect series of family archives, all classified in perfect order. I was shown some written by Mme de Staël, Talleyrand, Talma the actor, Lord Brougham, Lady Holland, and many others, of all countries."

The end of the year showed Mrs. J. very much of an invalid, constantly confined to her room, whilst J., with occasional entries in his diary of "very unwell," "severe headache," was almost as active as ever.

J. visited Royat again in 1908. He was accompanied by 


\section{I98 7. as Registrary}

Cosmo Gordon, and later Lionel Cust joined them. On their homeward journey they visited Moulins, where they were very anxious to see the celebrated picture by the Maître de Moulins which was hanging in the sacristy of the cathedral. No official was to be found, and they would never have seen the picture had not J. boldly approached a confessional box, pushed aside the curtain, and spoken these words to the priest inside, "Oserai-je vous addresser, Monsieur, au milieu de vos devoirs?" -after which he very politely asked to be shown the picture. The priest was undoubtedly surprised, but he came out and showed them the picture; and was perhaps not sorry for the interruption.

Here are a few extracts from the last letters J. wrote to his wife:-

Hôtel Continental,

Royat-les-Bains, P.D.D., 23rd July 1908.

". . . I am about to send you sous bande, Le Livre de mon Ami, by Anatole France. I cannot let you wait to read anything so delightful till my return. To think that I have had it on my shelves for more than a year without so much as opening it! Cosmo read it first, and insisted on my taking it up at once. It is a real masterpiece-all about child and boy life. I can only hope that you will laugh over it as immoderately as I have done, and then in places it is quite pathetic."

\section{Hôtel Continental, Royat-Les-Bains, P.D.D., 30 th July 1908.}

". . . Has my darling Dorothy been behaving prettily on the old pergola? and is she over? I am glad to hear about the Ceanothus. I am afraid the Buddleia (which I got after seeing one at Newstead) does not mean to flower this year.

"... I am more disgusted than words can express about the rubbish called 'The Marathon Race.' What are we coming to? ... I I hope you were well enough to read Rosebery's speech about Old Age Pensions. That's 
another piece of reckless folly. If I may compare great things with small, it is, like my domestic difficulties over large structural changes ${ }^{1}$ all coming one on top of the other without a thought of how the finance of them is to be met. I don't believe Asquith knows any better than I do how he is going to meet these new charges."

Mouniss, 14th August 1908.

"The Church ${ }^{2}$ is a really wonderful thing. It is the sole remains of a great Cluniac Monastery, and, all things considered, has not suffered much at the hands of the revolutionary people. It is full of curious things-a great Gothic reliquary-stone screens separating off certain chapels-and some fine fragments of stained glass. Near it are a few fragments of the conventual buildings-a few arches of the cloister and so forth. Having explored this we came on to Moulins-a picturesque town à la française, full of bustle and movement, especially to-day, which is the eve of the Assumption of Our Lady. 'The French may abolish religion and public worship, but they won't prevent the people from observing this popular festival. . . . There is a cathedral here, but not of the best type, and it has been practically rebuilt, but it contains a good deal of old glass, and a very fine old painting of the early French School, which I think I remember at the Exhibition at Paris. It was given by one of the Dukes of Bourbon, this being their capital, and is in excellent condition.

"Also we managed by a great stroke of luck to get into the Library, and see the Bible of Souvigny-an illuminated MS. of the Vulgate written and painted A.D. 1105. Lionel and Cosmo were delighted: and even I, who don't specially study miniatures, discreetly admired."

Auxerre, 15th August 1908.

". . . It has happened unluckily that whereas I have been pluming myself on missing the Bank Holiday in England, I have fallen on I'Assomption, which, preceding Sunday, makes two general holidays together, something dangerously like our horror. Further, matters are complicated here by a Concours Agricole! Cosmo and I are sent out

1 The alterations at Scroope House.

2 Souvigny. 
to a dépendance, Lionel alone being allowed a room in the hotel. Luckily I discovered (or imagined) that I had stayed at the same hotel with Shipley in 1893 or 1894. I really think what I said was true, and I posed as ancien client de la maison, which ended our difficulties."

On J.'s return he found his wife weak and ailing, only kept alive by her interest in others, always bearing her constant illnesses and her continuous discomforts as those who belong to a great race do bear them. On the 13th of December 1908 Mrs. J. died. I do not think I could pay a more adequate testimony to my dear friend than to quote what appeared in the Times the following day:-

"Many a Cambridge man all over the world, when he reads of the death of Mrs. J. W. Clark, early yesterday morning, will feel that a life has ended which had a deep and a wholly good influence on his own character during his impressionable undergraduate days. Cambridge will, to all who knew her, seem in future a poorer, an emptier place.

“" Mrs. J.,' as her friends always called her, had a genius for friendship and a social tact which made even the shyest of Freshmen feel at home under the hospitable roof of Scroope House. Gifted with a high power for organisation, she initiated and helped forward many of the numerous projects which play a considerable part in the life of a University town. Among these, the triennial Greek Plays and the performances at the A.D.C. were conspicuous; but hers was a many-sided activity. For years she gave freely of her time and counsel to help the poorer inhabitants of the town. Especially did she devote herself to the attempt to improve the conditions of life for the 'bedmakers' and 'helps,' and Mrs. J.'s ' Barnwell Mothers, well known to her friends, repaid her kindness with genuine gratitude. Also she took a warm interest in the Girls' Friendly Society, and district nursing in Cambridge owes more than one can say to her energy and devotion. She was a sincere Churchwoman, and cared deeply for the welfare of the Established Church. 


\section{Mrs. F.'s Deatb}

"Mrs. Clark suffered from a severe illness for many months, borne with unflinching courage and with indomitable patience. Well or ill, her first thought and constant care was for others. Cambridge has, indeed, lost in her a most lovable woman and a lady of a very noble character."

J. was never the same afterwards, but he would not acknowledge it; he went on as ever 'doing the next thing.' A few hours after her death I went to see him, and found him very calm, working in his study on some archæological article, but though to the outer world he remained unmoved, something had snapped; in a way he had lost his bearings, and though he struggled on he was never what he had been.

In 1909 he paid his Easter visit to Paris, accompanied by Mr. Geofirey 'Iatham, but this time we have but few letters. The travellers went on to Milan, Florence, Siena, Bologna, and Venice; here J. worked as usual in the Marciana, and here he saw much of his friend Horatio Brown. On his return he stayed a few days in Paris, and was back in Cambridge on 6th May.

During this visit he spent some time with the Wilsons at Certaldo, and Sir Harry has been good enough to contribute the following account of the visit:-

"My wife and I had spent the winter of 1908 in Rome (where J.'s introductions to some of his particular friends had added greatly to our enjoyment), and in order to see something of country life in Northern Italy, we had in the following spring taken, on a six weeks' tenancy, the old Castello at Certaldo, between Empoli and Siena.

"To this abode came J., who was travelling in Italy with his friend Mr. Geoffrey 'Tatham (now Junior Bursar of Trinity), to pass a week with us on their way to Venice. A happy week it was to us, and as we are glad to know, to J. and his companion also. To begin with, the weather, which had been cold and squally on our first arrival, grew suddenly warm and still; the whole countryside was gay with blossom; the valleys of 'Tuscany laughed and sang for very joy of the spring. J., to whom (as to ourselves) the experience of inhabiting an Italian 'castello' 
was a novelty, entered into everything with the zest of a schoolboy. Indeed, he made some of us feel quite elderly with his vivacity and his enthusiasm. He clambered gleefully about the hills and gathered flowers, while we sate and sketched; he drove with us for miles through the quiet country roads in our modest 'legno'; I am not sure that he didn't do a little birds' nesting on his own account, while I was busy with my butterfly-net. As was always the case, he was adored by the servants, who were entranced by his genial manner and his whimsical sayings; and Alberto, our handsome Bolognese, was his devoted slave.

"Almost all his tastes, artistic, antiquarian and scientific, were catered for at Certaldo. A stone's throw from our door stood the gloomy old house, with its squat brick tower, where Boccaccio was born and where he died. 'This interested him greatly, as did the church of SS. Michele and Jacopo, where the cenotaph of the author of the Decameron is still to be seen, and the bust erected by the Vicario Lattanzio Tedaldi in 1503. Then there was the Palazzo Pretorio or Vicariale, formerly the stronghold of the Alberti, and afterwards the official residence of the deputy of the Florentine Republic, rich in armorial plaques of Della Robbia ware, and in frescoes by Pier Francesco and other Tuscan painters, with its munimentroom full of well-tended archives, among which J. browsed contentedly. A large atlas of early maps, which had been offered to us by the proprietor of the local wineshop, and which we ultimately purchased, was also much enjoyed by him. Its contents corresponded closely with certain items in a catalogue of Lafreri's prints, published in a recent monograph by Father Ehrle, the Librarian of the Vatican. Sitting under the big blossoming pear tree in our courtyard, J. collated them with that minute accuracy which distinguished all his work. Another day, when strolling, after a drive with my wife, in the neighbourhood of the town, he came upon one of the curious deposits of marine fossil shells, which are a striking feature of the geology of the district, and set to with his pocket-knife to dig them out, nor did he rest till he had made us all join in the sport, to see who could disinter the largest bivalve!

"One golden morning we drove over to San Gimignano and lunched at the little albergo of that most attrac- 


\section{Certaldo}

tive town. I shall never forget J.'s delight at the frescoes of Benozzo Gozzoli in the Church of Sant' Agostino, and the curious learning, 'worn lightly, like a flower,' which he displayed of the obscure feuds of the Ardinghelli and Salvucci. Siena he visited alone with Mr. Tatham, and came back in raptures with the well-remembered glories of its Duomo which he had not seen for many years.

"It all ended too soon, as is the way with the pleasant things of life, and the day arrived when we had to bid him and his friend God-speed; but the old affection had been revived and strengthened, and we felt that we had seen $J$. at his very best. It was good to learn from a letter he wrote shortly afterwards to my wife, which she will always treasure, that his sojourn with us upon our hill-top had been as agreeable to him as it had certainly been to ourselves."

J. had recently resigned the post of Auditor at Trinity College, a post which he had held for twenty-seven years, and which he valued because it gave him an official connection with the College to which he had always been warmly attached. On his retirement the College presented him with a silver épergne, of which he was very proud. The following letter refers to the presentation:-

12 th May 1909.

"This is not a letter-only a line to tell you that on Sunday, 23rd May, I am to dine in Hall, and the Master is to say something (I hope not much) about me in the Combination Room afterwards. I do hope that you will be able to be present.

"I am deeply touched by the kindness of everybody in this matter, and especially Capstick and Innes. They intend giving me a special present of their own, in addition to the piece of plate, to mark their sense of what they are pleased to call 'my uniform kindness to them.' 'To-day, when I regretted to Capstick that he had had so much trouble over finding a day when all persons could be present, he replied, 'You are quite worth it.' All this is vastly gratifying to me in my old age. I shall write to you again shortly." 


\section{4

On 19th June J. was presented by his friends with a series of essays and articles entitled Fasciculus Ioanni Willis Clark Dicatus. This book, got together somewhat in the form of the Festschrift common in foreign Universities, was intended as a tribute from many friends of their appreciation of J.'s kindness, and of the tireless way he had worked for the University. The last time I saw Mrs. J., perhaps giving away a secret, I told her that such a volume was in active preparation. The knowledge of this gave her deep pleasure.

Throughout the first half of $1909 \mathrm{~J}$. was engaged as Joint-Secretary with Professor Seward in making the arrangements for the celebration of the centenary of the birth of Charles Darwin. This was held on 22nd, 23rd, and 24th June. The first of these days was that of General Admission, and he records at the two-o'clock Congregation "the Wooden Spoon made what we hope is its last appearance," this being the last year in which the order of merit was retained in the Mathematical Tripos. For the Darwin celebrations J. put up Professor E. Perrier of Paris, Lord Esher, Alfied Lyttelton, and the Rev. J. H. Ellis. ${ }^{1}$ The part that he had taken in the rather elaborate arrangements was warmly appreciated by the ViceChancellor, who wrote as follows :-

\section{The Precincts, Canterbury,} 1 st July 1909.

"MY DEAR J.,-I really do think that mutual congratulations all round are quite in place. I thank you heartily, dear kind friend, for what you say about my poor part in the proceedings; but it is to you and Seward that everything is due. Nothing could have been more perfect than your arrangments for the great scenic effects, which will last for life in the memory of all who were present. You know too well for me to tell you what I feel about your personal kindness to myself in it all.

"On every side-from the Chancellor, from foreign delegates, from all sorts of people-I hear the same thing said. Ever your affectionate A. J. Mason."

1 Recently a most generous benefactor to the University. 


\section{Royat}

Immediately the ceremonies were over $\mathrm{J}$. left for Windsor, on his annual visit to his friends Mr. and Mrs. Lionel Cust; on his return he was busy writing the Introduction to Mr. H. Fletcher's Oxford and Cambridge Delineated.

This summer J. made his usual "cure" at Royat, and was back in Cambridge by 21st August. The following two letters were written whilst he was away :-

\section{1 st July 1909.}

"I got here on 'Thursday ${ }^{1}$ afternoon after a pleasant journey in an empty train. The place is said to be fullcertainly the hotel is-and I have ingeniously utilised the said fullness to get my pension cut down to 10 francs a day on the ground that my room is wholly insufficient. It is a bit gloomy, and lacks view. I see only the back of another wing of the hotel, two acacias in the garden, and a pot of hydrangeas on the steps leading to the kitchen.

"My doctor tells me-what I could have told him-that there is nothing the matter with me, and he adds that perhaps I may be let off with fourteen baths. . . .

"I wonder if you care for the Ancien Régime? If you do, read the Souvenirs du Baron de Frenilly (1768-1828)Paris : Plon, 1909. I have at last found a book in which a gentleman describes the ancien régime, its gradual transformation, and final destruction. It is beautifully written, with a good deal of humour."

17 th August 1909.

" Oh! these letters, these letters! Like you, I put off the pleasant ones till I can do them quietly, and that moment has now arrived. I have a clear half hour before me before I start on an expedition which I have evolved from the depths of my own consciousness, and am therefore looking forward muchly to it.

"I am glad that you are so happy at Cambridge. I am afraid that I do not care for the Long Vacation. It has entirely changed from the peace and quiet of old days, which we in our thoughtlessness called dull, and become a string of interruptions of tiresome people. I try to say to

3 29th July. 
them, 'Very sorry, I can't see you. I am busy'-but ' uno avulso non deficit alter.' Now I am being worried by a man who thinks I can write a chapter of reminiscences of Alfred Newton currente calamo. Idiot! $\mathrm{He}$ has written to me here!

"... I I remember Woodham (of Jesus) used to say to people who were going away', 'What do you want to go away for? You'll never see anything so good as King's Lawn.' Perhaps not; but I should like to drive a broad gravel path right across it, move the bridge back to where the Founder put it, and replant the avenue. In addition to that, I should build a new Lodge on the west bank of the stream, well out of sight on the south side, pull the old one down, and build a good range of chambers on its site. Voilà!

"I wonder, with all your experience of men and things, you should care a $d-n$ what reviewers say. 'They must say something. They are always saying unpleasant things about me, for instance, but I pay no attention. Macaulay never answered a criticism, and so many of the worst blunders and misrepresentations in his History pass unnoticed.

"The first of the two bon-mots you send me is one of old Professor Miller, who said some sixty years since, 'If we could get rid of the Undergraduates and the Town, Cambridge would be a pleasant place to live in."

J. was much interested this year in writing his Reminiscences of Cambridge (quoted earlier), which form the most valuable part of this book. He took extraordinary pains to be accurate, and would often carry the parts as he wrote them to some old friend for criticism and correction.

The following letter written at the close of this year is typical of many such. J. had a genius for friendship, and those to whom Scroope House had been a second-sometimes the only -home never forgot him or Mrs. J. :-

65 Pont Stheet, S.W., 30 th November 1909.

“My DEAR old J. W.,-Nothing could have given me greater pleasure than your letter. It recalled all sorts of 


\section{His Last Illness}

old and delightful memories and the days when you and your dear wife were kindness itself to me: and 'Lucinda' too-how well I remember it all! You have always been a prince of friends to all of us, and it is delightful to me that you should have remembered me just on this particular occasion when life has suddenly taken on such roseate hues for me. Indeed I cannot think of anybody that $I$ have ever known who has a greater gift than is yours for friendship and sympathy: it gives me a warm feeling to remember you and write to you.

"I think one of your own books would be a delightful present. I can think of nothing nicer: and your suggestion of the one upon the 'Care of Books' could not be bettered. Thank you so much-so very much. As to returning to S. Africa, I have got until the end of January in England, and I should so very much like to come to Cambridge and pay you a visit: some time in January would suit me admirably, I think, and, if I may, I think I will write to you later on and suggest a date or dates to you. May I do that? I do think you will like Miss P.-I don't think you could help doing that. I have been most incredibly lucky, and I feel very humble about it tho' also rather gloriously happy. Thank you again for your letter and your friendship, dear old J.-Your affectionate

A. E. B."

J. seemed to be exceptionally well in the early autumn of 1909. Unfortunately he caught a chill while attending a Greek Play rehearsal at the end of November, and this was the real beginning of his last illness. He recovered sufficiently to be able to pay a visit (accompanied by Mrs. Edward Clark) to his old friend Dr. Douty at Stratford-on-Avon, and it was while staying with him that it first became apparent how ill he really was. He now almost ceased to keep his diary; the last entry but one - "Not well. Did not leave the premises"-is typical of the few entries he made. The last entry I have found was on 17th December, "J. went to bed." 1 This was the beginning of a long and

1 This is in Mrs. Edward Clark's handwriting. 
trying illness, with many fluctuations between hope and fear. At times he would rally in a wonderful way, leading those who watched him with devoted care (Edward and his wife never left him) to think that life and a certain amount of work might yet be possible for him. But these bright intervals grew less frequent and his mind often wandered. Probably a somewhat profound remark made to Willy by a member of the present Cabinet was literally true. Discussing Mrs. J.'s death at the time, Willy remarked how wonderful it was that his father's interest in life and his power of work seemed so little affected by it, devoted as he had been to her. "That may be," was the reply, "but don't count on it: we all thought the same when Campbell-Bannerman lost his wife, but it killed him." In the spring of 1910, however, he was sufficiently recovered to be able to travel to Ventnor, where he took a furnished house. During his stay there he improved slowly, and, when King Edward died, had recovered sufficiently to write to the ViceChancellor as to the ceremonial to be observed at the proclamation of King George. He felt very keenly not being able to return to Cambridge in time to take his part in the ceremony as he had done ten years before, when as Registrary he proclaimed King Edward from the steps of the Senate House. He returned to Cambridge on 12th May.

In June he writes to Sir Harry Wilson as follows:-

IScroope House, Cambridge, 14 th June 1910.

"Dear Harry,-Thanks for your affectionate letter. I think I can give a good account of myself on the whole, and my friends vow that I look as well as I did, or better than I did, before I was taken ill in December. But six months is a big slice to be taken out of one's life; and I doubt very much about the future. 'There are lots of things I can't do for myself-e.g. I have still to be carried upstairs, and I get very easily tired. However, next month I am to begin my work at the Registry again-or try to do so.

"Now we are in a state of anxiety about this Indian 


\section{Resignation and Death}

business. ${ }^{1} I$ don't much believe in it-but am told I am all wrong-in a minority of one as usual.-Ever your affectionate

J. W. Clark."

During June and July he was wonderfully better, and was able on 30th July to go and stay for a few days with his old friend Mr. Marlborough Pryor. He hoped against hope to be strong enough to resume work at the Registry, but in August he began to go down-hill again, and in September he resigned his office in the following letter addressed to the Vice-Chancellor :-

\section{Scroope House, Cambiridge,} 15 th September 1910.

"Dear Mr. Vice-Chancellor, - When I fell ill in December last, I was led to hope that my unusually strong constitution, coupled with medical skill, would lead me to recovery. I regret, however, to be obliged to admit that I cannot now expect complete restoration to health. And though I trust that I shall be able for some time longer to continue my private work in the interests of the University, I feel that the honourable course is for me to place in your hands my resignation of the Office of Registrary. I should be glad, therefore, if you would cause the Members of the Senate to be informed that the office will be vacant on October 1st.I an, dear Mr. Vice-Chancellor, Your obedient Servant,

"J. W. Clark."

The Jubilee Meeting of the Church Congress was held in Cambridge at the end of September, and J. was a Member of the General Committee. He had asked Lord Halifax to stay with him at Scroope House for the Congress, and had sent several things to the Loan Collection. Although he was now very ill he would not allow any of the arrangements to be altered, and his great anxiety was lest his illness should inconvenience his guests in any way. Fortunately just at this time he rallied slightly, but it was only a flash in the pan, and on the afternoon of 10th October 1910 he died.

1 The offer to Willy of a seat on the Council of the Viceroy. 


\section{H A P'T E R I X}

\section{J. AS I KNEW HIM}

Having now come to the end of my chronological survey of J.'s life, I want to try to draw a picture of him as he presents himself to me when I look back over the thirty years of our friendship. To this I have added reminiscences of $J$. by his friends Mr. Lionel Cust, Mr. A. C. Benson, and Mr. W. H. Pollock, who write of different aspects of his many-sided activities.

The first time I met J. was about the middle of the Michaelmas term, in my second year, 1881. At that time I was attending Michael Foster's lectures, then perhaps at their best, and at their best they were unsurpassed. Whether it was because J. was Secretary of the Museums and Lecture Rooms Syndicate, or whether it was because he was a close friend of Foster's, he used to collect the Physiological Laboratory fees. This was an act of pure kindness on his part, yet we undergraduates all firmly believed that he used to have the odd shillings out of the guineas as his commission! One day between noon and one I knocked at the door of his room, on the ground floor facing south which was then used as the Syndicate Rooms, and, entering, faced an extremely well-dressed undergraduate who was just being told by $J$. in no uncertain voice that he didn't care a damn whether he came from Magdalene or whether he came from Hell, but that he would have to pay one pound eleven shillings and sixpence before he passed that door. The undergraduate paid and passed the door. I was very frightened. And then with that sudden change which all who knew him must have seen repeatedly, his temper in a moment melted away. He asked me all about myself, and by the time my fees were $p_{210}$ aid and very precisely entered 


\section{Scroope House}

in a book, I had been invited to visit him "any Sunday evening after dinner, and mind you come some Sunday soon."

Greatly daring, a week or two later I called, between nine and ten, one Sunday evening in November, at No. 1 Scroope Terrace. The parlour-maid said Mr. Clark was dining at Scroope House, and led me through a slip of a garden, through a door now walled up, through a lot of tall shrubs, to the door of a great house brilliantly lighted, and in a minute $I$ was ushered into a stately dining-room full of guests just finishing their dessert, not one of whom I knew. I was the only one without a "wedding garment" and again I was frightened, and again I was made happy and at ease by the kindly tact of our host and by the genuine friendliness and interest that Mrs. J. showed in me from the first moment I met her. That Sunday evening I found a second home, a home in Cambridge, where for thirty years I could and did turn for help and infallibly receive it.

J. was fond of entertaining his friends, and during the greater part of his married life kept almost open house, but he never cared for large formal dinner parties-"droves" as he called them. He liked a good dinner, though he had strong views as to food, and could not abide what he called "the charred limb of a ruminant," but he considered that good food took a very second place to good wine. He kept an excellent cellar, and when he entertained anyone whom he considered worthy of his best claret, great were the preparations made beforehand. The wine was got up in good time and stood on the chimney-piece or near to the fire to be warmed, and was carefully decanted just before dinner. Sometimes it was found to be over-heated, and then there was much tribulation. On one occasion, when a great connoisseur was staying at Scroope House, this accident occurred, and J. was so distressed that he implored his guest to superintend the warming operation himself on the following night. He was somewhat consoled and his guest considerably disconcerted to find, when the wine was decanted, that it had been over-heated 
again! That he rarely smoked was possibly due to the fact that tobacco and claret will not go together; and, though he provided tobacco for his friends, woe betide anyone who began to smoke before the bottle was finished. "Finishing the bottle" was a point on which J. was very firm. When the decanter had circulated for the last time, he would (if there was still some wine in it) rise from his chair and walk round the table pouring wine into his guests' glasses until he had emptied it. He had specially tall, funnel-shaped glasses for the after-dinner claret, and he never allowed them to be filled more than three parts full, lest the bouquet of the claret should be lost. He sometimes, however, broke his own rule by filling a friend's glass to the brim, in his anxiety to see him "finish the bottle."

J. and his particular friends used from time to time to dine together at what they called "Harmonies in Bordeaux," when no wine except that grown in the Bordeaux district was drunk. The late Mr. Henry Bradshaw, Mr. Gerald Balfour, Mr. Alfred Cole, Mr. George Prothero, and Mr. (now Professor) Langley were usually among J.'s guests on these occasions. One of the "harmonies" has fortunately been preserved, and is here given:-

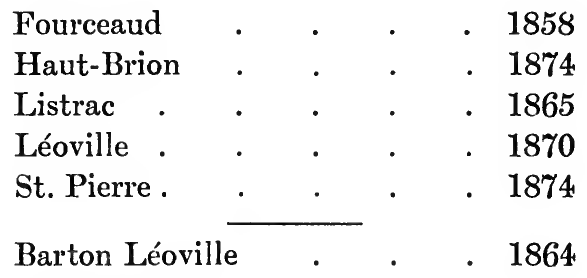

15 th August 1885.

It would be a mistake, however, to suppose that J. was anything but always abstemious both in what he ate and what he drank. He drank wine because he liked it; but, when in the early nineties he thought it had (to use his own words) ceased to like him, he at once gave it up of his own accord 


\section{His Dress}

and rather against the wishes of his doctors. Subsequently, though he had throughout his life a horror of excess, he was always careful to explain that this abstention from wine was due to no teetotal principles, and that he was as anxious to entertain his friends and watch them enjoy his claret as he had been in what he used whimsically to call his "drinking days."

J. was absolutely unmusical, and it was literally true of him that he was only conscious of the National Anthem being played by seeing the people stand up. He would remark when questioned on the subject that he did not mind music more than any other noise. Yet he sat with pleasure through Wagner's Ring, and at one time used to go regularly to the Handel Festival. His dramatic instincts on these occasions made up for his lack of musical sense. It was no doubt on this account that in 1890 he was asked to join the Committee which organised a performance of Gluck's Orpheus in the Cambridge Theatre. It is said that he was recommended by Professor (now Sir C. V.) Stanford in these words-"You'll see how J. will mount Hell!"

In his dress J. combined a certain measure of the fashions of an older generation with an unconventionality all his own, and it was characteristic of his strenuous nature that he always dressed at top-speed. I do not suppose he ever took more than a quarter of an hour in getting up in the morning. He wore as a workaday costume a double-breasted morningcoat, with waistcoat and trousers to match of some dark, usually heather-coloured tweed, but no one ever saw the coat buttoned. He also wore elastic-sided boots-in my time rapidly becoming extinct-and as a rule a shocking bad hat of the bowler type. He had a surprisingly springy gait, lifting himself on his toes at each step, a way of walking which was perhaps equalled but not surpassed in springiness by Mr. Gladstone.

On the other hand, he was adamant on the subject of evening dress. Even when spending the night at some remote 
French country inn, hardly ever to my knowledge-and I have travelled much in France with him-did he appear at dinner without changing into evening dress. At University functions, clothed in a flowing silk gown, with his picturesque white hair and beard, both worn rather long, he was indeed a noticeable figure, and I trust that I shall hurt no one's feelings when I use a phrase he would himself have enjoyed, and say "that he played most of them off the stage."

His unconventionality was part of his energy, part of his wish to have something done and go on to do something else. Yet it was only in the last years of his life that he could bring himself to dictate to a shorthand clerk, and he never would tolerate a typewriter. I have already referred to his kindness in carrying with his own hands soup or other helps to appetite to those who were sick. If he wanted anything carried the way he was going, it seemed to him that the best and quickest way was to carry it himself. I once met him about midday walking along the King's Parade carrying a large chandelier hung about and sparkling with cut-glass prisms. It must have been rather a feat of strength, but to him at least the proceeding did not seem unusual. If he wanted a thing done he did it, and as Registrary he would take off his coat and tack up a placard or straighten a carpet in a way which would I fear have shocked his predecessors in that office. But with all this he had a great respect for the position he held. He resented and opposed any suggested changes in the status of the Registrary, and rebuked, in a way that left a doleful echo in the ear of the offender, any student who entered the Registry incorrectly attired, or who in any other way showed an inadequate appreciation of University etiquette.

As Secretary to the Museums and Lecture Rooms Syndicate he took his work at the Museums, as he took all work for the University, very seriously. He systematised the methods of keeping the accounts, then much more voluminous than now, and he kept all the books in his own handwriting. It was 
only in the comparatively late days of his life that he began to employ a clerk, and I remember well one January in the late eighties, when he was in bed with a severe cold-I always believed it was influenza, but $J$. never would allow that he could have influenza-his sending for the ledgers and daybooks, and, with a temperature when most men would wish to forget the world, seeking to balance his accounts. He had a marked gift for arousing the devotion of those who worked for him, in spite of a somewhat unbridled tongue and of an occasional outburst when he really let himself go. No servant ever wished to leave his service, and those who during the last few years of his life helped him to arrange his collections, copied for him, etc., would have done anything for him.

His kindness and genuine care of the Museums staff was paralleled by the interest he took in many of the working men, the clerks and the sons of Cambridge tradesmen. $\mathrm{He}$ had the gift of helping most who came across him and of drawing out their affection. From many letters written to him by his working-men friends I quote the following:-

\section{Cambringe, 9th September 1907.}

"Many thanks for your very kind letter, which needless to say I was delighted to receive. I was surprised and sorry to hear that you had got into such a low state of health before leaving England. I hadn't dreamed of your being run down to such an extent, but it is very consoling to learn that the course you are now on is proving beneficial, and I sincerely trust you will return feeling quite your old self once again, and that the treatment will prove a lasting benefit.

"I am afraid you will consider me rather a lazy chap having not answered your letter before this, but really I must ask to be excused for leaving it so long; the fact is we have been very busy indeed of late, and when I have finished for the day I have felt too tired to sit down and write even to you, but I meant to write to-day, so have left off early to do so. See!

"It was very kind of you to enquire of my wife and 
I am very pleased to be able to send a good account of that lady; she is getting on just fine and seems quite happy about expectations, and is continually preparing for the great event. Every spare moment is devoted to needlework of one description or other to be placed aside ready for the time when it will be required.

"Cambridge is very quiet indeed at the present time; everyone connected with the University seenıs to be away; but I suppose in a week or two we shall notice them getting back, and then I hope to see you, and quite well again."

Lowestofit, 7 th January 1906.

"I beg of you to accept photo enclosed in return for the one you so kindly gave me when I came to see you. I came back to Lowestoft the next day, but did not start work until this week as trade is still very bad here. I have been fixing a dynamo and have been unlucky enough to sprain my back, but not bad, I am glad to say, as I am nearly all right again now; but it made me lose time as I had to rest a bit, which I did not like I can assure you, as I can always do that when I have no work to do. I expect to be fairly busy next week as we have some temporary lighting to do for the Election Candidates here, about 200 lights outside the Conservative Club and several arc lamps at the Liberal Club, so between the two I may manage to make a full week for a change.

"I am pleased to say the wife and boy are both well. I should have liked you to have seen him when I was down home, but he is such a weight to carry that I could not manage to bring him up with me. I am thinking of taking a photograph of him, and if successful I will send one on to you, and I think you will be a bit surprised to see how fat he is. I must conclude now, wishing you a happy new year."

Of course there is the reverse. It would be idle to suggest that J. had not patent faults. He was very quick-tempered and even passionate-somehow or other nowadays we all seem too indifferent about everything to be passionate-he 


\section{His Temper}

was also very unbridled in his denunciations. Words-I might say language, as the landladies call it-sprang not only to his lips but from them. He could, and did swear, and at times he said very bitter things, mostly with a humorous twist, sometimes at individuals, sometimes at what he called "the malice of inanimate objects," but on the whole these outbursts blew over, and seldom when "things had quieted down" did any rancour remain. Like most eager and intensely busy, vigorous men, he was very impatient; he could never "suffer fools gladly." I am afraid if there was any suffering the fools did it. We who knew him intimately loved him, but there were others, and as those who know any man intimately must necessarily be few in number, it remains that he was not universally popular. I remember hearing of a most respected bookseller who, not being able to supply some work which $J$. wanted at the moment, had to listen to "an outburst": he stood on the door-step of his shop, wringing his hands and crying so loud that his voice crossed the street, "And think of Mr. Romilly, sir !"-J.'s predecessor from 1832-62. Well, from whatever angle you survey J., he was unconventional. As he was fond of saying himself, "Je ne suis pas comme tout le monde." 


\section{CHAPTER $\mathrm{X}$}

\section{J. BY SOME OF HIS FRIENDS}

Berore passing on to Mr. Cust's and Mr. Benson's contributions, I give the two following passages, which I have selected as typical of what J.'s many friends wrote of him after his death. The first is taken from an article in the Cambridge Reviere:-

"The news that $J$. is gone will be profoundly felt, not here alone, but by many a man far from Cambridge, who has never read a page of the stately row of volumes which bear the Registrary's name. Such men will remember the brotherly kindness with which one much older than themselves, high in office in the University, received them : they will remember the home to which his unbounded hospitality welcomed them again and again: not a few will remember times of difficulty, illness, or sorrow when he helped them, cared for them, and comforted them. Among all else that he accomplished, this demands a special recognition, that he did more than anyone to make friendly intercourse between undergraduates and seniors a reality. There was no angling for popularity in this : he never affected the slightest interest in the athletic achievements of any of his young friends, and he spoke his mind with refreshing plainness when he considered them in fault. His goodness to them sprang from a genuine sympathy. It ranks among the happiest memories in the lives of very many. . . ."

The second is part of a private letter written by an old Trinity man who happened to be staying at Oxford :-

"I don't believe there was anybody who had a greater power of arousing affection than he, and I have heard and talked about him all over the world. As far as I 


\section{Lionel Cust}

am concerned his death changes the whole aspect of Cambridge to me. It almost brings it down to the level of this beastly place. When one considers that one was only a single unit amongst a whole milky way of people passing through Cambridge for years and years whom he made to feel that they were particular friends of his, one realises-or perhaps hardly can-what a tremendous and far-reaching effect he had. . . . I write with a heavy heart, for I did love that dear old man."

\section{REMINISCENCES BY LIONEL CUST}

My acquaintance with J. W. Clark did not date back before my coming up to Cambridge in 1877. I had a slight knowledge of having seen him at Eton on more than one occasion, but nothing more. I think that our first actual meeting was on 20th November 187\%, when my tutor, Mr. Prior, took me to the Registry to be matriculated, ${ }^{1}$ since owing to illness I had been absent from Cambridge and had missed the ordinary matriculation. 'The introduction was of course merely formal, but it lingers in my memory that the impression of $J$. at the age of forty-five was not very different from that of thirty years later.

It was not till February 1878 that I really made acquaintance with Mr. and Mrs. J., and I think that the 3rd February must have been the first evening spent under their hospitable roof, then at No. 1 Scroope 'Terrace. We had many bridges easy to cross in order to make acquaintance. My principal Eton friends, my seniors, who lent me helping hands in life-L. M. Powell, C. M. Newton, Edward and Alfred Lyttelton, J. E. C. Welldon, and others-were all intimate friends at Scroope Terrace, so that I lacked no introduction. Another powerful link was the generous friendship extended to me, among so many others, by Henry Bradshaw, whose word and opinion were at all times like law with J. Sunday evenings began from that date to be spent either with Bradshaw at King's College

1 J. was then acting as Deputy for Dr. Luard. 


\section{$220 \quad 7$. by some of bis Friends}

or with the J.'s at Scroope Terrace, with the latter frequently at dinner.

There were special reasons which tended to promote friendship between J. W. Clark and myself. It happened that as a boy $I$ had taken great interest in the study of heraldry and genealogy, in family -history and archæology. J. was then deep in his enthralling occupation of completing his uncle Professor Willis's monumental work, the Architectural History of the University and Colleges of Cambridge. The bulk of this was completed, but there were certain subsidiary sections of the work for which J. was glad of assistance, and gratefully accepted such as I could afford him in preparing the history of Eton College, the chapter on libraries, and details about heraldry and historical portraits. All this produced a sympathetic friendship which readily deepened into personal affection.

The real intimacy of my friendship with $\mathrm{Mr}$. and Mrs. J. may be said to date from June 1880, when to my intense delight they asked me to accompany them on their projected visit to the Passion Play at Ober-Ammergau. We left London on 22nd June, and, travelling by Flushing, Frankfurt, and Munich, arrived at Ober-Ammergau on Friday, 26th June. We stayed at the house of a family called Veit, most of whom were engaged in parts of varying importance in the Passion Play. 'The play itself took place on Sunday, 28th June, and the intense interest and deep feeling aroused by the performance in all of us could not be described in mere words. J.'s love of the theatre seemed to reach a climax when witnessing the performance of these simple peasants. Though not addicted to external expression of piety, and even resentful of any undue display of it, he was sincerely religious at heart, and it was evident that the play moved him deeply.

From Ober-Ammergau we visited the Tyrol, and were joined by Lawrence Jones, who had met us at Ammergau. We went across the beautiful Bavarian highlands by Mittenwald to Innsbrück. At Mittenwald we had a slightly amusing 
adventure, in that mine host, or hostess, at the inn, being short of room, showed us into a vast kind of state reception-room with four beds, assuming that the lady would not object to passing the night in the same room as Lawrence Jones and myself. Nor was it easy to find accommodation for Mrs. Clark elsewhere. From Innsbrück we crossed the Brenner to Franzensfeste, and thence to Lienz. From Lienz we went up to Windisch-Matrei, where we spent two days, and thence across the mountains to Kals and to the splendid region under the Gross-Venediger and Gross-Glockner. We were all in first-rate spirits, the weather fine, the scenery magnificent, and the mountains carpeted with flowers of almost incredible beauty. J. was a good walker, and Mrs. J. a patient and uncomplaining traveller, whose staying qualities were somewhat overrated by her husband. The second day's walking was longer than was contemplated, ending in having to cross on foot the huge Pasterze glacier, and to put up at the rough, though quite clean and comfortable, Glocknerhaus on the Franz-Josephshöhe by the side of the glacier. Mrs. J. was sadly tired on arriving there, and $I$ have always feared that the strain and exertion of this day left some permanent trace upon her constitution. This did not affect our happiness at the time, and I remember well sitting out on the rocks in the sun, with edelweiss growing like a weed about us, in full view of the Gross-Glockner across the immense glacier, while J. read aloud Robert Browning's "Saul " and other poems.

From thence we went down to Heiligenblut and back to Lienz, whence we struck south by Toblach to Cortina, where we spent a few days. Although it was July, Mr. and Mrs. J. had a great wish to go down to Venice, and this we did. On 14th July we took a carriage and drove down to Cadore, to Longarone, where we stayed the night, and on to Serravalle and Vittorio, whence we took the train to Venice. We spent six days at Venice in great enjoyment, only troubled by hot nights and mosquitoes. It was a real pleasure to be in a place like Venice with J. The extent and diversity of his 


\section{F. by some of bis Friends}

interests, the width and practical use of his knowledge, all made him a most valuable companion and instructor. $\mathrm{He}$ was specially interested in the restorations then going on of the exterior of St. Mark's. With his usual facility for making friends $J$. enlisted the interest of a young architect then in charge of the works, whom I believe to have been Giacomo Boni, since so well known in connection with the excavations at Rome. Under his guidance we were taken all over the outside of St. Mark's and shown plans and sections of the foundations, and also over the Ducal Palace.

Another interesting visit at Venice was to Mr. Rawdon Brown, who, as we found, was smarting from his failure to conciliate and appease the Poet Laureate, Mr. Tennyson, who with his son had called upon him to enlist his help to remove a trifling grievance which had plunged the poet into great dudgeon. The old gentleman's disappointment was quite removed by the genial and sympathetic attitude of J., who at once humoured all his hobbies and made a friend of Mr. Brown for ever.

Venice was by no means the end of our journey. We went next to Verona, and from Verona to Trent, where we took a small omnibus, or stellwagen, up a very hot valley to a little place called Borgo, and by Castel Tessin and Canale St. Bovo made our way to Primiero. Small incidents remain in the memory. One was that when we were about two miles out from Borgo or Trent, I forget which, Mrs. Clark found she had left something behind, upon which the driver dropped his reins and ran back to fetch it, leaving us in unwilling charge of the horses and carriage, and sweltering in a small tightcovered vehicle. The wonderful dolomites of Primiero were a great delight to J., and we would gladly have spent a longer time among them. We had to make our way back, stopping at San Martino di Castrozza, Campidello, and Seiss. From Seiss J. and I walked over the Schlern down to the valley at Atzwang, and thence by rail to Innsbrück, Munich, Mainz, and so to England. 


\section{Lionel Cust}

During such a journey friendship must inevitably grow to intimacy. With Mr. and Mrs. J. it became the linking of my life to theirs. In Germany the kindly-disposed but not overobservant casual acquaintance more than once assumed that $I$ must be Mr. and Mrs. J.'s son, and thus I learnt to know and value Mrs. J. not only as one of the best and noblest of women, but in the light of an intimate relation. In this light I spent the short remainder of my days at Cambridge. Scroope Terrace had moved into Scroope House in order to be near Mrs. Clark, senior, and the larger the house the ampler the welcome found within its doors.

I was of course only one of many drawn from many generations of Cambridge undergraduates who came under the influence of J. He had an immense capacity for friendship, not only with younger men in different classes of life, but with men of his own standing and near his own age. I have often heard him speak of men like Dr. Henry Jackson, Sir Michael Foster, Henry Bradshaw, Sir Richard Jebb, Dr. Luard, and others in terms of affectionate respect, as if they were brothers in a family rather than only fellow-workers in the cause of the University. On the other hand, he was a good hater, as all men of strong affections should be; and dislike, once begun, was seldom mitigated. J. was a born organiser; whether it were a museum or library, the A.D.C. or a Greek play, the accounts or history of a college, the reception of royalty, even the matrimonial affairs of a friend or the funeral of a colleague. Somewhat of a spoilt child evidently at the start, he was sometimes slow to see that his organisation might not be the best possible, or to admit that the system on which others worked, if it were distasteful to him, might not have some good points to its own credit. This made him occasionally somewhat difficult to work with. He was bitterly disappointed at not being chosen to succeed Professor Robertson Smith as University Librarian; but the rebuff was a blessing in disguise, as it left him open to accept the post of Registrary to the University, a post thoroughly congenial to him, for which 


\section{J. by some of bis Friends}

not only was he by nature and temperament most admirably fitted, but had qualified himself already by acting for several years as deputy for Dr. Luard.

The post of Registrary, moreover, kept him in contact with the younger members of the University. He always felt it deeply whenever the son of any of his former friends came up to the University and failed to avail himself of the friendship that $J$. was so ready to offer him. For my own part, my removal from Cambridge only intensified my friendship with Scroope House. From that time to the end my visits were frequent, until the house seemed like a home. As the younger man grew up to meet the older on his own ground my rapport with J. got steadily clearer and stronger, until there was nothing in our lives in which we did not take as it were a mutual share. This was especially the case with his books, for throughout the compilation of The Care of Books I was able, being then at the British Museum, to render him some assistance. On one occasion, in April 1894, J. joined me at The Hague, and we made a special expedition to Zutphen to see the chained library in the church there, of which he has given a full description in his book. Here, as elsewhere on the Continent, J. displayed a wonderful power of getting the right side of librarians, curators, etc., and not only obtaining what he wanted at the moment, but making them willing and even anxious to assist him after his return to England.

There was no better person to travel with than J. In the mountains he was not only interested in, but able to expound the mysteries of nature. He was quite as much a man of science as a bookworm, and it is possible that his work in the Museum of Comparative Anatomy was really the best work of his life. His scientific studies, at all events, gave him system, and enabled him to carry out historical compilations with lucidity and accuracy. In turning over his books and papers, I was often struck by finding some casual note of my own carefully inserted just at the right place, where it might be useful for future reference. Curiously enough, although I was 
often present at the discussions upon the English and French theatre between J. and his friends, I was very seldom with him at the theatre in person. I remember a discussion at Scroope House, at which, I think, Professor (now Sir Charles) Waldstein, Harry (now Sir H. F.) Wilson, and Frank Pryor were present, when it was first decided that a Greek play should be produced; and the Ajax of Sophocles was selected, on the ground of the admirable opening it presented for the peculiar personality of J. K. Stephen. This must have been in 1882, as I had then gone down and was working as a clerk in the War Office. I was able, however, to get leave and come to Cambridge to help in the production of the Ajax, in which I took one or two non-speaking parts, but in the rehearsals I was able to give J. some practical assistance.

Unluckily, I was unable to get leave the following year, and so was unable to accept a similar share in the production of The Birds of Aristophanes. In this, however, and subsequently in the Eumenides, the Ion, the Iphigenia in Tauris, I was continually able to help J. with minor details. I was, however, lucky enough to accompany J. to some special theatrical performances in London, such as the German plays by the SaxeMeiningen Company; and I well remember our enthusiasm over the Julius Coesar and the Iphigenie of Herr Barnay and his company, and our patient despair throughout the long-drawn agonies of Das Käthchen von Heilbronn. Another interesting experiment was taking $J$. and his wife to one of the early cycles of Wagner's Ring der Nibelungen in London, in which J., in spite of his constitutional inability to appreciate music, seemed deeply interested. It was always a wish of his to attend some of the performances at Bayreuth as a dramatic experience; but I do not think that this wish of his was ever gratified. J. was, however, always ready for a dramatic experience, whether it was a new piece at the Théâtre Français in Paris or a performance of the Bijou Amateurs in Cambridge. He was genuinely happy behind the scenes of the theatre, and it was a real pride to him to take a youthful friend and penetrate into the august 


\section{$226 \quad 7$. by some of his Friends}

mysteries of the Comédie Française, where he had so many personal friends. Towards the end of his life I was able to provide him with a dramatic experience which pleased him very much, for while J. was our guest at Windsor he was invited by King Edward VII. to attend the theatricals at Windsor Castle given in honour of the King and Queen of Sweden. The late King always had a great regard for J., dating back from His Majesty's Cambridge days.

It was my good fortune to be asked by $\mathrm{J}$. on behalf of the Vice-Chancellor, Dr. Chase, to assist the University in the reception of the King and Queen at Cambridge in March 1904. Only those in the inner working of these complicated arrangements could understand how preponderant was the share of $\mathbf{J}$. in bringing them to perfection. Hardly a step was taken, a word spoken, which had not been as carefully rehearsed as if it had been a Greek play.

It is difficult to recall more than a few episodes of a friendship lasting over thirty years. One can scarcely omit, however, noticing J.'s passionate love of the river Thames-" the sacred river," as he liked to call it. For many summers in succession he never failed to come and have his annual row on the 'Thames. In earlier days this was with myself, Dick Durnford, and some other friend, ending up with a dinner at Walter Durnford's in Eton. Later we were joined sometimes by his wife, sometimes by mine, occasionally by both, or by his son Willy. When he was past seventy, and his health was beginning to fail, J. was still ready and capable to take his turn at sculling from Queen's Eyot to Boveney Lock.

It was this capacity for enjoyment which made J.'s life a happy one. He enjoyed his work, he enjoyed his friends. $\mathrm{He}$ enjoyed the theatre, quand même, good or bad as the performance might be. He was something of an epicure, and an expert in wine, of which he had a quite artistic appreciation, until warnings of health made him give up drinking wine at all. With such tastes it follows that he was an excellent host at home and abroad, who knew how to impart a Parisian flavour, at any 


\section{A. C. Benson}

time or place, to an otherwise commonplace dinner-table. He loved little economies for himself, but never stinted expenditure for his wife, his sons, or his friends. It might almost be said that he enjoyed the misfortunes or ailments of his friends, so keen was his pleasure in trying to minister to their sorrows or their necessities. J. was essentially human, his failings as human as his virtues. One secret of his sympathetic friendship with younger men lay in the feeling that if they had any troubles or difficulties to contend with, he at all events might have, if he had not actually, had to contend with precisely the same difficulties himself, so that they were perfectly intelligible to him.

Another matter on which J. was fully qualified to speak was architecture, especially collegiate and ecclesiastical. His views were practical rather than æsthetic, and through his years of study of architectural history they were based on a foundation of solid and seasoned experience. When the War Memorial Buildings at Eton were decided upon, J. was one of the members nominated to serve on the Committee of Taste. After the main work had been entrusted to a young Etonian architect, J. most generously devoted much time and personal labour to helping the architect with sound and practical advice. The disinclination of the architect to avail himself of this advice gradually led $J$. to relinquish his interest in the buildings. It may safely be asserted that much of the hostile criticism with which the completed buildings have been greeted would have been avoided had the architect been willing to be guided by the experience of Mr. J. W. Clark.

\section{REMINISCENCES BY A. C. BENSON}

I first made acquaintance with J. when I was a boy at Eton, in the late seventies. He was often at Eton at that time, working at the history of the buildings. He discovered somehow that I was interested in the antiquities of the place; and he had a peculiar gift, which was extremely and subtly 


\section{$228 \quad 7$. by some of bis Friends}

flattering to a boy, of talking about his researches without the least condescension or stiffness, as though he were discussing them with an equal. This was all entirely natural and spontaneous on his part, and done without any diplomacy. $\mathrm{He}$ was fond of strolling about in the early afternoon in the Playing Fields, and used to sit on the river-bank looking out towards Windsor. I can see him now walking in a swift gliding way, with short steps; and there I used to join him sometimes. He would give me proof-sheets of his book to read, and even invited suggestions, which of course delighted me greatly.

When I went up to Cambridge in 1881, he was at once paternally friendly. I used to dine with him, together with other undergraduates, at Scroope Terrace. What we found so particularly engaging about him was his charming and indulgent greeting, as though he were a good-natured uncle talking to favourite nephews. We respected him as a man of learning and weight, and still more as a man of the world. He never attempted to talk down to us, and this was the great secret of his attractiveness. His look of bonhomie and content, his smiling eye, his pleasant lisp, the scraps of idiomatic French in his talk, the sense of his wide acquaintance with foreign places, his love of the French theatre, all gave a sense of mysterious backgrounds and wide range. We never thought of him as a Don, but rather as a man of cosmopolitan interests and high courtesy, who chose to live in Cambridge.

I came across him a good deal in connection with the Ajax and The Birds of Aristophanes, in both of which I took a small part. His good humour and enthusiasm when things went right-for he had the knack of praising generously, and exactly at the right moment-combined with his extreme testiness and ironical frankness when things went wrong, made him a most effective stage-manager. We enjoyed his conflicts with other officials; but no one of us ever resented his criticisms, because his paternal kindliness lay so close behind it all. And I am sure that what won the hearts of his undergraduate 
friends was that he was never superior, and never seemed to be making advances. You simply felt that he liked you, wished to see you, enjoyed your company.

I was away from Cambridge for twenty years; but came across him from time to time. I was always met with the same easy fondness, so that I felt that even if I did not see him for months together, I had a perfectly secure place in his mind and heart.

Of late years, at Cambridge, it was always just the same. I often met him, always felt the same sense of easy intimacy, which came, I believe, from the simple frankness with which he talked of anything that was in his mind, while he never forgot one's own interests and pursuits. And here I must mention the extraordinary charm which Mrs. Clark possessed. There was something about her which invited perfect confidence, and her gay and liquid laughter, which greeted anything that amused her, was always an enchanting sound. J. often said petulant and perverse things in her presence, but one was always conscious of the deep devotion and perfect sympathy which subsisted between them; it was a truly beautiful relation in its frankness and unobtrusive tenderness on both sides.

It is difficult to say exactly what $\mathrm{J}$. was. He was an antiquary first, and in a sense a virtuoso; but he had none of the faults of the virtuoso; he had a wide range of knowledge, and he was very accurate and painstaking in detail. He had, too, a remarkable gift of organisation, and the power of using and trusting subordinates, whose affection he always secured. It is almost impossible to describe the position he held in the University. He did not aim at influence, but it came to him and he enjoyed it. He was indiscreet, combative, provocative and incisive in talk. He never forbore to criticise friend or foe. He never repented, or withdrew, or qualified his statements. But the affection with which he was universally regarded swept all resentment away; and he was looked upon as a sort of spoilt child, who was not only allowed but expected to say exactly what he thought, and whose skirmishes and mots 


\section{$230 \quad$ F. by some of his Friends}

and jests were chuckled over and enjoyed. He was full of prejudices and whims; but one felt that whatever he said, he could be counted upon to do the just thing and the kind thing; and so he was honoured much and loved more. $\mathrm{He}$ never paid the smallest heed to convention, nor troubled his head about what people would think. He lived his own life on his own lines, did an immense amount of hard and useful work, and was welcomed in all companies, by young or old alike, for his loyalty and generosity, his salient humour, and his radiant geniality. He was one of those men who achieved the end of being a figure, a distinction which many weighty and worthy persons miss. And it is thus a difficult task to explain to those who did not know him exactly how this came about. For this particular gift does not depend upon either zeal or performance, but is bound up with the mysterious thing called charm, so difficult to capture or to describe, and which $J$. possessed in a conspicuous degree. 


\section{CHAP'TER XI}

\section{J.'S LOVE OF THE THEATRE}

J. was, from first to last, a whole-hearted lover of plays : good, bad, or indifferent. Not that he did not criticise, and criticise well, but I positively believe that he would rather see a poor play indifferently performed than none at all. $\mathrm{He}$ had a wide knowledge of the drama, and lived in regions in this respect quite unknown to me. Hence $I$ am very happy in being able to add this chapter written by $\mathrm{Mr}$. Walter Pollock, whose knowledge of the stage equals and in some respects surpasses even that of J.:-

It was some time before I went up to Trinity-I took my degree in 1871-that I first met J. W. Clark, of whom it is difficult to think or write by any other appellation than that of simply "J.," or, as I think he was more generally known to his friends when I first knew him, "J. W." With our first meeting began a friendship that lasted unbroken throughout his life. We lost sight of each other for a long time, when I went to live in the country, but when either had occasion to write to the other, the threads were taken up exactly as if they had never been dropped, and I do not know of any better proof of friendship than that.

As a boy I was fortunate in knowing many older people who were known also to him, but that was not the particular common ground on which acquaintanceship first began to develop into friendship. Before going on to that, $I$ feel that I must record how very much I-in common, I am sure, with many others-owed throughout my University career to a kindness, tact, and wisdom of experience on J.'s part, which 
never failed me then, and which $I$ found ever ready as of old on divers occasions in after life.

The common ground, mentioned above, was a great love of French dramatic and other literature, and of the drama and the theatre in England, France, and Germany-especially in France. For a considerable time after our first coming together, the number of English devotees of the drama, who knew and cared about dramatic doings in France, was absurdly small compared to what it became after the first visit to London, at the Opéra Comique, of a small band of actors, the pick of the Comédie Française, exiled by untoward events from their own historic stage. To all dramatic matters J. brought the same keenness and love of research that belonged to him in other pursuits. His vivid memory and description of plays and actors he had seen, and his knowledge of those he had not seen, were alike notable; and in later years he was second only, if second, to Palgrave Simpson in ever-ready, wide, accurate information as to matters of the moment or of history in the theatrical and dramatic doings of the great European cities. His interest was not, any more than was Palgrave Simpson's, one of dry learning; when he went to see a play, new or old, he went with the same lively anticipation that we have all experienced on our first introduction to the front of a real theatre. I forget who told a characteristic story of Thackeray, that he said to some friend or acquaintance, "Do you love the play?" and on getting for answer some sensible observation as to liking a good play, exclaimed, "No, no! That's not what I mean at all! Do you love 'the play,' going to a play, good, bad, or indifferent? I do." That was precisely J.'s attitude, or, as he often put it himself, a green curtain and a row of footlights were enough to make him happy on any ordinary evening. It is not everybody with whom we can go to "the play" with absolute certainty of being in sympathetic company. It follows naturally from what I have just said, that to "do a play" with him was to double one's own natural pleasure; or, I confess, in some cases, to be very well pleased 


\section{W. H. Pollock}

instead of bored, just because of his happily contagious delight in "the play," considered as an abstract form of enjoyment. If for a moment he himself felt just a shade of a suspicion of tiresomeness stealing upon him, then his pet phrase of a green curtain and a row of footlights was invoked, and never failed to "cheer up the sprites" of himself and his companions or companion, as the case might be. Unless the party was thoroughly homogeneous, it was, perhaps, best to go to a theatre with him alone, for it was not everyone who could "taste" and enjoy the ervigkindliche which was part of his nature and attraction, which led to occasional little petulances and jealousies of a most harmless kind, and which no doubt had to do with his unfeigned delight in "the play." Withal, this quality in no wise interfered with his power of criticism, unless one excepts that it preserved in him what we should all like to preserve, that enthusiasm of youth which makes one wishful, if not able, to be blind or impervious to such shortcomings as may exist in the work of even the greatest artists. He was indeed, despite strong likings and dislikings, a natural good critic of plays and actors, and his critical faculty had been cultivated by wide experience. It was especially in the case of French players that he was carried beyond criticism by admiration. Doubtless this was due to his intense liking for the best things in French ways and French institutions, which sometimes found expression in the humorously exaggerated wish that he could look forward to being appointed Sous-Préfet du Département du Cam, whenever the French invasion of England became an accomplished fact.

This, however, was no kind of bar to his recognising, with enthusiasm, genius or talent in English playwrights or players. 'The theatre, like the play, had in itself an irresistible fascination for him; and I well remember his engaging delight when Sothern, of Lord Dundreary and other fame, then at the zenith of his success, paid him a visit at his rooms in Nevile's Court, in company with some members of the Haymarket company and with John O'Connor, the brilliant painter 


\section{F.'s Love of the Theatre}

of scenes and, later, of pictures, who took a sketch of the rooms for use in a play by Tom Taylor, called $A$ Lesson for Life, part of which has its scene in rooms in college at Cambridge. Nor was the same simple and infectious delight wanting when he saw the admirable counterfeit presentment of his rooms on the stage of the Haymarket.

I have many lively and pleasant memories of plays, both in French and in English, seen in company with J. in London, but even more vivid is the recollection of meetings with him in and out of the theatre in Paris, the city where, in those days, and again in agreement with Thackeray, he found the top of his leisure enjoyment. I fancy that in later days Vienna, in dramatic art and social entertainment, ran Paris hard in his approval; but I do not know if it ever actually disputed supremacy. In the Parisian times, spread over some years, which are bright in my memory, the Theâtre Français provided casts for all its plays which one supposes can hardly have been surpassed; and it was at that house of classic fame that most of the evenings I recall were passed, though J., like myself, dearly loved a good melodrama, of which there was ample store at the Boulevard theatres, what with Dumaine, Lacressonière, Lafontaine after he left the Français, and others to fill the chief men's parts, while there was no lack of fine actresses, including Madame Lafontaine. Then there was Lesueur, inimitable in farce, comedy, especially in Une Partie de Piquet, and, when he condescended to it, feerie; and-but I dare not begin on general recollections, and must cling, dramatically speaking, to the House of Molière.

Certainly it was a fine company that for some way on from the early seventies of the last century had among its chief members such men as Bressant, Coquelin, Delaunay, Febvre, Got, Garraud, Laroche, Maubant, Mounet-Sully (pupil of Bressant, and then in the earlier stages of his great career), Thiron, Talbot, Worms, and such actresses as Mmes. Madeleine Brohan, Bartet, Sarah Bernhardt, Croizette, Favart, Dinah Félix (sister of Rachel), Jouassain, Reichemberg, Royer. J. 


\section{W. H. Pollock}

revelled in discerning appreciation of these fine artists and others here unnamed, and his associates, myself among them, revelled with him. I do not think there was ever between us any critical disagreement more than just enough on minor points to give zest to talk ; while that quality was also supplied by J.'s store of anecdote and illustration, suggesting themselves naturally to his swift mind as the ball of conversation rolled on. Of course he had special admirations-who has not?-for individual actors and actresses. I will not borrow a pet exaggeration of his and say that he was, for instance, "besotted with Bressant," since it would not have been easy to go too far in admiration of an actor unsurpassed in apprehension, in the resources of his art, and in that strange quality of "presence," which depends neither on stature, nor on feature, nor on voice or gait-is indeed undefinable in exact terms, but which helped to make Bressant inimitable in Almaviva, in Octave (Les Caprices de Marianne), and in the Marquis de Presles (Le Gendre de M. Poirier), while it was, perhaps, an inevitable handicap to his brilliant and subtle acting of 'Tartufe. It is then no wonder that on one occasion J. was filled so full of the combination of rare gifts and accomplishments which made Bressant's position as an actor unique, as to be absorbed by contemplation of it during one of many enjoyable talks over the Théâtre Français and its company at large. So that whenever there was a momentary pause in the talk he was impelled to break in with the words, "but to return to Bressant." I think we were none of us loath, on any repetition of the phrase, to act on its suggestion; but its insistence was such that it afterwards became a catch-word, and for years later, when certain intimates of J.'s were together, engaged in ordinary talk, instead of saying, "but to go back," they would naturally substitute, "but to return to Bressant." I catch myself sometimes saying it now, and having to account for it as best I can.

From Bressant to Delaunay is a natural step since Delaunay, after Bressant's retirement, succeeded to some of Bressant's 


\section{F.'s Love of the Theatre}

parts which, with his unerring sense of art, he approached from a different point of view. It was, however, while Delaunay was still figuring as the most wonderful of jeunes premiers, that my mother and I happened to be staying in Paris at a time when J. also was there, hard byto us, so that on most days we met. Delaunay also was a constant visitor to us, and naturally he and J. made each other's acquaintance. The slight and characteristic contretemps which presently followed could not have been altogether unforeseen by people who knew that each man was devoted to dramatic art and all concerning it, and that each was decidedly opinionated. They got on together capitally for a time, and then there came an occasion of difference of opinion on some point as to which each was convinced that his was the one and only right point of view. And of course each stuck unswervingly to his own guns. 'The next day I happened to be alone when $\mathrm{J}$. looked in to see us. He talked of this, that, and the other subject, and then, as I fully expected, brought the conversation to Delaunay. Of whom he said with an air of settled, one might say desperate, conviction: "My dear Walter, we all know that your friend Delaunay is one of the finest actors that can be imagined in his own line. But you must admit that his views on (whatever the matter in dispute had been) are of the narrowest, and that his way of expressing them is not ingratiating." Soon after J. had left, my mother returned, and while we were still talking of J.'s visit and his pronouncement, Delaunay arrived. He too made a preamble on impersonal matters and then fell to asking, with an air of unconcern, about our friendship with $J$. and his vocation. When J.'s position and claims to recognition had been explained to him he, too, came to his real object and said that it was very interesting to find that our English friend's pursuits and achievements were so varied and notable, "but that does not make me find him pleasant in talk, especially when he is wholly in the wrong." The two, however, each having shot his bolt, met on the pleasantest terms later on, and, indeed, became intimate friends. 
Another meeting which my mother and I had with J. has always been vivid in my memory. We were going to a play together and were to dine with him first at an excellent and quiet restaurant which he had discovered and which was known to but few English visitors to Paris. As many of his friends will remember, he had a really fine taste in the ordering of a dinner to fit a given occasion. He had commanded a repast exactly suited to this occasion, and we were just about to sit down in much content when a look of distress came over his face and he exclaimed with many apologies that he must rush back to his hotel- "I must have left it on my dressing-table; I can only hope it is there still!" One naturally asked sympathetically what "it" was, and the hurried answer came that it was a bag containing gold coins. "But," said my mother, vainly hoping to give comfort, "wasn't it locked ?" "What locked?" cried J. and fled. When very soon he returned, restored to peace of mind and pleasant anticipation, his exclamation was fully explained by the fact that the bag, now safely bestowed, was a small linen coin-bag which by no possibility could have lock or key. But the dramatic effect of finely mingled scorn and suffering in "What locked?" was such that Mounet himself might have studied it for a tragic moment.

J. was with me on one occasion when, at the Français, after an, of course, excellent performance of L'Ami Fritz, I went round to the Foyer des Artistes, which corresponds to the now extinct green-room of English theatres, where we met Mlle. Reichemberg. Very sincere compliments were paid to her on her own perfect performance in a perfect general rendering, and then she said to me, "And what of the piece itself?" "La pièce," I replied, "est" - and hesitated for a word, which Mlle. Reichemberg supplied with, "bien douce, n'est-ce-pas Monsieur?" The manner was as irresistible as the phrase, and $J$. was so delighted with it, and recurred to it so often, that this too became a kind of catch-word. Another catch-word between $J$. and myself came from his use of a 


\section{J.'s Love of the Theatre}

phrase which tickled my fancy when I first heard it. "What did you think of such-and-such a dramatic production?" I asked him. "My dear Walter," he replied, "I suspend it on my adunc nose." 1 Those who knew J. will know also why the expression struck me as complete. I fell into asking him questions chiefly in the hope of getting the same answer again; and finally it became between us a "common form" of compendious and sufficient criticism for certain occasions.

Several times J. himself " took up his pen," to use another favourite phrase of his, as dramatic author or adapter. The first work of his which I saw in this line was an English version of Le Courrier de Lyon which he wrote specially for the A.D.C. Up to that time the play was known in England by Charles Reade's very skilful and dramatic English version, first played, I think, by Charles Kean. Unluckily Reade's dexterity in adaptation was equalled by his unhandiness with the French language. He called his piece The Courier of Lyons, which is stark nonsense. J., as was natural in him, gave to his new version the strictly correct and well-devised title of The Lyons Mail. When Sir Henry Irving was about to revive the old play, I called his attention to this. He grasped the point at once, and adopted J.'s title; and thus, through J., the very effective piece will now always be known by its only proper English name. J.'s version, first acted at the A.D.C. in 1870, and revived with marked success in 1895, was remarkable in many ways as an adaptation, but chiefly for the fact that though he carried out with singular craftsmanship the task which he deliberately set himself of eliminating altogether the female interest, he yet managed to retain, in all its force, the central dramatic motive. This drastic change threw a considerable burden on the player of Joliquet, a burden which on the first performance of the play was admirably sustained by Mr. Herbert Gardner, now Lord Burghclere, who later on was associated with $J$. in the production of another play written

1 "Adunc nose" was, of course, a familiar rendering of Horace's nasus aduncus, a symbol of scorn. 
specially for the A.D.C. and performed in 1872. This was entitled Peer? or Peasant? and was an adaptation only in the sense that J.'s encyclopædic knowledge of the drama and the stage helped him in devising some of the melodramatic situations and effects by which the piece is distinguished.

In the original sketch or scenario there seems to have been a scene on the field of Sedgemoor which does not appear in the published version. Of this Lord Burghclere kindly writes to me: "I well recall it because I pressed upon J. (our scenic artist as you know) that the stage should be strewn with dead horses; and when to J.'s question as to how that was to be arranged, I replied with the suggestion 'stuffed figures,' I well remember J.'s Homeric laughter." J.'s laughter was truly Homeric, as were some of his denunciations. Another anecdote of J. at the A.D.C. I owe to the kindness of Mr. Charles Brookfield, and I here give it exactly as he was good enough to write it to me :-

" J. W. (owing no doubt to some abnormal formation of the palate) had a peculiar method of speech which offered irresistible temptation to anyone afflicted with the vulgar, parrot trick of mimicry; and many of us at the A.D.C-James Lowther, Algie Lawley, Willie Elliot, Charley Newton, Bobbie Milnes (I am speaking of the late seventies), and others used to vie as to who should give the most lifelike imitation of our dear old friend. It would be not only tiresome but impossible to convey the vagaries of his pronunciation by means of phonetic spelling; suffice it to say that mysterious guttural g's and grasseyés r's and approximate w's took the place, in J. W.'s mouth, of most of the consonants : to attempt one example, 'My dear Lowther' would probably come out as 'My ghear Wowvargh.'

"'The popular 'Mr. Speaker' of to-day was, in those dawngolden times, the equally popular president of the A.D.C. One morning, when we were busy arranging the setting of a scene for a farce called $A$ Nice Firm, Lowther (another J. W., by the way) was looking out furniture or "properties" somewhere 


\section{0

under the stage, and I was talking to him through the 'gravetrap' in the voice of the Superintendent of the Museum, telling him how admirably the parts of Messiter and Moon had been played in days gone by, at the A.D.C. by-I forget whomand how badly they were about to be played by Brookfield and Lawley. After a while I made a move to the next room just as the real J.W. strolled on to the stage, and, seeing me go forth, and, believing me to be out of hearing, he called down the trap, ' My dear Lowther, I wish you would use ?your influence with Charlie Brookfield to make him alter his reading of Messiter. I cannot conceive what can have induced him to play the part like a music-hall giant comique. ...' ' Not a bit like it, my dear Brooks,' cried Lowther in reply. 'Mine's much better than yours.' And, in admirable imitation of the Superintendent, he repeated his actual words, 'My ghear Wowvargh,' etc., as he clambered up the steps from below. I re-entered just in time to see the two J. W.'s face to face; I don't know which looked the more astounded."

It was especially for the A.D.C. (to go back in date) that J. wrote a version of Ruy Blas, performed in 1867. Ruy Blas was played by Cyril Flower, afterwards Lord Battersea; Don Salluste by the Hon. Alfred Charteris, who, coached by J., was surprisingly good. The whole play was made very telling in spite of the immense difficulties. One striking effect, borrowed legitimately from another play, was obtained by a watchman of sonorous voice calling under the windows, just after the tragedy of the final scene, "Fine night. Madrid is quiet. All is well." Apart from all "devices," the arrangement and the writing of the version were excellent, and there were some fine lines in the rendering of Ruy Blas's great speech to the Privy council, opening with:-

" $O$ virtuous statesmen, honourable peers,

Grey with the wisdom and the weight of years,

In such a conclave are ye met to drain

The bitter chalice of the tears of Spain?" 


\section{W. H. Pollock}

In this production J. himself appeared as a special messenger to the Privy Council, and, as in other small parts, spoke with a capital enunciation, despite the peculiarity of utterance which, in another and far more arduous part in which I never saw him, would not have been appreciably in his way. This was the character of Raoul de Morière in his own three-character and one-act play, How Will it End? adapted in the best and fullest sense of the word from Feuillet's Un Cas de Conscience, and printed in 1872. It was not an A.D.C. piece, and was given at private houses only twice within my knowledge, once in London, and once much later in Cambridge. The part of Raoul is, as I have reason to remember, by no means easy. A good judge who saw J. play it told me that his acting was excellent.

To go back to the A.D.C., J.'s wholesome love of melodrama, and of a big tirade in the third act, ending up with "Hence, adultress!" hurled by someone at the female villain, was by no means an exclusive passion. He delighted in Sheridan and Goldsmith, and prepared versions of two of Sheridan's comedies for the A.D.C. But he there undertook, and brought to successful issue, a much bigger business in 1885, when he made himself responsible for the arrangement and staging, as well as for the scenery of Henry IV (i), which was a singularly good all-round performance. Here, on a question of the character of Falstaff, he and I had one of our infrequent differences of opinion. The very clever actor (Mr. Harry Newton) who played the part conceived that Falstaff was a real poltroon and carried out his conception with great skill. J. defended this view as strongly as I opposed it. ${ }^{1}$

Some excerpts from J.'s letters will illustrate in some detail his critical attitude towards certain of the French players in whose methods and performances he took delight. And first of these I take two passages concerning the great tragedian

1 Those who are interested in the question may be referred to Maurice Morgann's Essay, which originally appeared in 1777. It was republished by the Clarendon Press in 1912. 


\section{2 \\ F.'s Love of the Theatre}

Mounet-Sully, who during his earlier times at the Français had not quite attained to "begetting" the "temperance" that gives smoothness to "the very torrent, tempest, and whirlwind of passion." Now J., dearly as he loved a good swashing melodrama, writ with artistry and containing a cataract of a tirade in the third act, and much as he could humorously delight in a "barn" melodrama acted barn-wise, yet had a nice objection to an exaggerated expression of emotion on the boards of a great theatre. This objection was perhaps a little overnice, in that sometimes, as in the case of Mounet, it prevented him from discerning great qualities of understanding and feeling that were partly obscured by faults; in this case over-emphasis with voice and gesture of physical expression. Thus he wrote with uncommonly faint praise of Mounet's Gérald in La Fille de Roland at the Français. For the piece, in a letter written in July 1875, after seeing it, he finds little to praise, but adds, "There was one passage which I applauded vehemently, as giving expression to all my feelings about the dear country I am now in. Here it is. Charlemagne is hoping for the glory of France:-

"'Ta gloire ! oh ! puisse t'elle, aux époques prochaines,

Croître en s'affermissant comme croissent les chênes

Offrir l'abri superbe et l'ombre de son front,

Nation maternelle, aux peuples qui naitront;

Afin qu'on dise un jour, selon mon espérance :

Tout homme a deux pays, le sien et puis la France !"

As for the acting, he spoke in high commendation only of Maubant as Charlemagne, of Laroche as Ragenhardt, and of Mme. Sarah Bernhardt, then, as I believe he and I both thought, at her true best, as the heroine. I saw the play, but not with him, and I tried to persuade him to my faith that Mounet's great qualities were but obscured by want of shading. However, the real point is that four years later he wrote with absolute enthusiasm of Mounet's Ruy Blas at the same theatre, which the great tragedian has never left. On this occasion, in April 1879, J. wrote thus: "I have had quite the greatest 


\section{W. H. Pollock}

dramatic sensation of my life. I did not know I could be so moved by a play as I was last night by the fifth act of Ruy Blas. It is too much almost for pure pleasure. I felt it was all real, and that Salluste was really going to be killed. I had no idea Mounet had it in him. He was quiet and intense, without any ranting or extravagance, and no one, not even Lemaitre himself, could have given better the lines : ' Je te tiens écumant sous mon talon de fer!' or the famous 'Tenez, pour un homme d'esprit, vraiment, vous m'étonnez!' or the flash that seemed to light up his eyes as he yelled out 'Pardieu! j'étais laquais! quand je serais bourreau?' But the greatest effect, theatrically, was made by following Salluste slowly to the door, and suddenly bringing his sword down on the table with :-

'Oui, je vais te tuer, monseigneur, vois-tu bien?

Comme un infâme! comme un lâche! comme un chien !'

I sat there panting till the curtain slowly fell."

There are those among us who remember vividly how $J$. delighted in dwelling, in his talk, on this particular effect. Those who knew him well, but who did not happen to hear him descant on this particular theme, will readily imagine the exact enthusiasm, emphasis, intonation, action with which he described how Mounet "threw the sword down with a great clang on the table, and flung out the words as if they came white-hot from the furnace of his passion."

Between 1875 and 1879 Mounet had made extraordinary progress in the fine art of subduing his natural tendency to ebullience so that the outward showing of intense passion became harmonised to the true optique du theâtre; and it is surely worth noting that J., who seemingly had had no opportunity of watching the intermediate stages, immediately recognised the great change, and from that time became one of the most devoted admirers of Mounet's genius, though in this as in other cases he always preserved a justly critical attitude.

Of Les Danicheff he wrote in 1875 with great enthusiasm: 


\section{J.'s Love of the Theatre}

"I do so wish you could have been with us, for it is very long since I saw so grand a drama so splendidly played. You feel in quite a different atmosphere from that of ordinary stage plays; among people who act from noble and pure motives, but who are yet quite as human as those other persons who break the seventh commandment to slow music in the plays of M. Dumas. Moreover it possesses great literary merit, bristling with good things, which, put into the mouths of two or three minor characters, relieve the sombre melancholy of the drama."

Another instance of enthusiasm, for play as well as for players, is found in a passage written in 1885 which clearly refers to a performance of Alfred de Musset's On ne badine pas avec l'Amour. J. cordially loved and admired-as who that really knows them does not?-those unique "comedies" by Musset which really contain, along with brightest wit and lightning flashes of character, the very essence of romance and tragedy. On this occasion he was as much in love with the play as he had been in earlier days when he saw it with Favart in the part of Camille, but he found occasion for once to be justly indignant with his beloved Parisians, or with that section of them who then went regularly to the Français on Tuesday nights, when evening dress was expected, though not enforced, in the audience. The letter was written on Wednesday, 8th April, from the Hôtel St. Romain: "The Français last night was delicious. Delaunay younger and brighter than ever, and Bartet a vast improvement on Croizette, though she don't quite come up to Favart in my opinion. She did not do the ending right, and she had put a thing like a big brioche on her head, made of velvet and feathers, which niddlenoddled when she flung herself on the prie-dieu in a way that spoilt the tragedy of the situation. D. [clearly Delaunay] quite agreed with me, and the head-dress is to be suppressed." Delaunay seems from this to have been at the time semainier, or stage-director for the week; and what is more important, the passage is one of several proofs in the letters that he and $\mathrm{J}$. 


\section{W. H. Pollock}

had, as people of such artistic sympathies should, quite got over their former mutual prejudices. "'Ihen," J. went on, "that vile fashionable audience came late and left early, and actually dared to put on its cloaks and hats while Delaunay was on his knees in the last terrible scene. He told me he could not help thinking of the audience instead of his part, and trying to keep them quiet. Even the British Public behaved better than that when the piece was given in London."

Thirteen years later, in January 1898, he wrote of another light of a brilliant company-Coquelin, in Cyrano de Bergérac; and the greater part of the letter is a criticism, with every word of which I personally agree, of the play, and of the actor in that particular part:-

"It is a monologue for Coquelin, who goes on talking, talking, talking, surrounded by a parcel of lay-figures, who, in stage slang, 'feed' him. No doubt he has a number of fine things to say, but to me he is not sympathetic; and he has made, $I$ think, a great mistake in supposing he can play a romantic character. C. de B. is an historic personage; soldier, duellist, poet, contemporary of Molière, who pillaged his plays, and especially took the famous ' $Q$ ue diable allait-il faire dans cette galère' from him. He was cursed with a specially long and hideous nose, about which he was strangely sensitive, and fought endless duels with those who made the slightest allusion to it. 'Et tirer son mouchoir c'est tirer son linceul,' says one of the characters. He is in love with his cousin Roxane, who has set her affections on one Christian, a dull stupid soldier, but as handsome as poor Cyrano is ugly. So Cyrano determines to protect this rival of his in every way, writes his love-letters, and even woos the lady for him in the dark under a balcony, an extraordinarily clever scene, but utterly unreal and impossible. Finally Christian is killed, and Cyrano dies fourteen years afterwards in a sort of epilogue, under trees in a convent garden of which Roxane seems to be abbessautumn leaves falling and all that. 


\section{F.'s Love of the Theatre}

"This somewhat thin story is stuffed out and bolstered up by some very clever padding which brings on a crowd of episodic personages, courtiers, soldiers, actors, etc., who are always moving about and keeping the stage filled with everchanging colours. But I could not conceive the faintest interest in Cyrano himself. The whole notion of the sacrifice he makes is too absurd to be accepted even on the stage, and the one thing that might have helped one to believe in it-a fine romantic presence in the principal actor-is wholly wanting. He could not help his nose, but he might have been tall and graceful, which poor dear Coquelin is not."

As I turn over J.'s letters on matters dramatic in search of a particular reference my eye and attention are caught by a shrewd and characteristic passage in a letter from England (1904) to a friend in Paris. "I am sorry you did not like OEdipe Roi. People's tastes do differ so, as Mrs. Bouncer profoundly observes. Englishmen, accustomed to the namby-pamby society mumble of their stage, have no feeling for a grande tirade; and when Mounet or his brother, M. Paul Mounet, whose voice is loud, I admit, let themselves go, Englishmen invariably say they rant." In this, as was often the case with J.'s criticisms, there was a very real truth; but, in his eagerness to present it, he had at the moment forgotten that there were other aspects of the question. To illustrate this, I well remember with what enthusiasm he described to me the first (or nearly the first) performance, at the old Prince of Wales's 'Theatre, of Robertson's Caste, by what for convenience one may term the Bancroft Company. "Here," he said, with whole delight, "in the very first scene you have two English gentlemen talking, sitting, moving like English gentlemen, speaking so that the whole house can hear them, yet seeming to speak only to themselves. It is the same with their gestures and their changes of place. In the same spirit and in the same way the whole play is carried through up to the final curtain. No Parisian acting can beat it." This was an accurate judgment, and J.'s momentary forgetfulness was doubtless due to the fact 


\section{W. H. Pollock}

that as time went on the vogue for naturalness-inculcated before the Bancroft era by Charles Mathews chief among others-had degenerated into slip-shodness and slurring and, to use a favourite word of J.'s, "mumbling." This he always very properly detested, as, very properly or not, he detested various derogations from dramatic art, as he both knew and conceived it, which at various times have proclaimed themselves as the New Drama. Thus, when, in his later years, he was persuaded (and I fancy it took some persuasion) to go to a performance given by the Irish players (who, as a friend of J.'s writes to me, were really excellent, but not to J.'s taste), what he said, in his most emphatic and penetrating tones when asked for his opinion at the end of the evening was, "A set of incompetent amateurs mumbling rubbish in the dark." Indeed J.'s dramatic criticism of plays and players was apt to have a Jehu-like touch. "Many critics do there be" who can play the Jehu after a fashion; but assuredly not too many who possess the true knowledge and taste which were always at the back of J.'s opinions, however hasty or terse they may by accident or intention have been in expression. I do not call to mind many instances of his "damning with faint praise" in the case of playwrights or players. In such matters he liked and used, broadly speaking, "a good fat brush"; yet no one better appreciated subtlety when it was unaffected, as witness his enthusiasm for the plays of Musset. It is true that Musset combined breadth with subtlety in a fashion of his own. What J. "would not have at any price" was preciosity.

Again, he had a very clear belief that the real purpose of the drama was not found either in using the stage as an obvious conduit for a playwright's convictions on moral, political, or semi-religious ethics, or in attempting a literal record of things and people as one sees them when there are no footlights, no paint, no powder, in short no theatre. 'The desire to make the stage a mere photograph, without any touching up or toning down, of life outside the theatre, had no recommendation to J.'s judgment. One of his comments upon it was that the 


\section{F.'s Love of the Theatre}

logical consequence would be, in the case of an "interior," to build up the fourth wall of the room, generally indicated by the proscenium and float. What he would have thought of the new ideas, one might call them regulations, which forbid the use of an "aside" or a soliloquy in any circumstances, at any rate of present-day life, can but be inferred. But I fancy that his opinion of such strangely devised fetters for the modern playwright might have been as strongly expressed as it was in the dictum "Rubbish mumbled in the dark." But to return to the excellent instances of J.'s cast of thought and happiness of expression found in his letters. Here is one which, though, as will be seen, it does not express a final judgment, is decidedly characteristic. It concerns Othello at the Français : the letter does not mention what French version of the play was used. J. greatly admired the whole effect of the performance and singled out for special praise M. Paul Mounet's Iago. Concerning the great tragedian who played Othello he said very justly, "As for Mounet it is difficult to judge him on a single representation. It is a very careful and elaborate performance-too elaborate perhaps-and the Orientalism of it seemed to me to be extravagant. There is certainly too much falling down, added to an epileptic seizure, and I am inclined to doubt whether an Oriental would have got in a rage at all. He might have been very angry with Iago, but with his wife he would have thought it all Kismet and strangled her as we drown kittens." This may be or may not be so ; it leaves aside the question of how far Shakespeare's conception is "Oriental," and also the fact that in Shakespeare's play Othello appears as a naturalised Venetian. But I have quoted it chiefly as being an exception that proves a rule. It is the only case in my knowledge of a curious inconsistency in J.'s judgments on matters dramatic. For, in spite of this expressed view as to what ought to be Othello's attitude, to be expressed presumably by the actor of Othello, towards Desdemona, he yet had a passionate admiration for Salvini's Othello, which certainly was intended to be very Oriental, and 


\section{W. H. Pollock}

certainly in the last scene was nothing if not raging. Fechter came much nearer to the suggestion in J.'s letter than did Salvini. As to the Italian actor, I well remember the trend of many conversations and arguments with J. upon the rendering which Salvini gave; arguments wherein we agreed about the earlier scenes, including the dismissal of Cassio, after which we parted company. But, generally, a passage in another of J.'s letters speaks decisively for itself on that question. "I once made a Tripos List," he wrote, "of the best things I had seen in the way of acting." He set out the scheme of this Tripos, which I do not quote in full because he left out many English and Continental actors of whom I know he thought highly. The noteworthy point to illustrate what has been said is that he put "Salvini in Othello" in Class I all by himself, and added that " after Salvini a broad line should be drawn. He is not only the best actor I ever saw, but he went farther than I thought dramatic art could go." Close on this he wrote in high praise of M. Mounet-Sully's OEdipe, and this passage is so characteristic, and will recall J. so vividly to anyone who knew him, that it is worth quoting almost in full :-

"Mounet in OEdipe rises to the height of tragic power. He not only puts before his audience the profundity of sorrow for a crime of which he is, in fact, innocent; but he portrays his character. OEdipus is before you-the rather vulgar selfsatisfied person on whom all things have smiled, and who, when he does talk to his inferiors, does it in a very condescending, patronizing way. Such a man feels the crash more than another would; and the royalty in ruins is something appalling as a picture of despair. I tried to copy it here [Cambridge] when we played (Edipus, and was only scolded for putting horrors before the audience. I replied that my critics evidently had not read the play, and advised them to go home and do so."

To turn to another French version of a Greek tragedy, the following passage shows not only how well J. knew "Greek Play," but is also a good instance of how alert and ready for new, even at the expense of old, impressions he kept his mind; 
a quality as valuable in a critic as in an artist. The concluding sentences make one wish that J. had "taken up his pen" for the burlesque he suggests:-

"I went last night [21st August 1907] to the Français to see Electra. I don't feel quite so sure as I did before that Sophocles was a great dramatist. A one-part play, the principal character in which is always screaming, is not attractive. Mme. Silvain is excellent, from a certain point of view, but if she would only have given us ' $a$ few brilliant flashes of silence' her performance would have been infinitely finer. For instance, she spoilt the recognition scene, which was famous, if I mistake not, even in the ancient world, by yelling at the top of her voice, and Orestes did the same. It resembled nothing so much as two cats screaming at each other. If only she had fallen into his arms in silence! One can imagine how Rachel would have done it had she attempted the part. I confess that I sympathised a good deal with Clytemnestra, who for ten years or more had endured the presence of this 'furie,' as she calls her, at the domestic fireside. What a burlesque might be written on it! The dresses were good, and the scene pretty, but I doubt its accuracy both as a landscape and from an archæological point of view."

I quote from one more letter concerning the actors at the Français because it shows how evenly, as a rule, its writer beld the scales of dramatic judgment even when he was most strongly inclined to praise, as he certainly was in the case of the Français company generally, and not least in that of the admirable actor Edmond Got. He went in December 1882 to see Le Roi s'Amuse, was full of high expectations, and was "sorry to record a very great disappointment. Worth seeing it is; but, alas! badly done from beginning to end, and, unlike the Français, the small parts are so bad; the courtiers are common, and the stage-business clumsy, full of blunders. Mounet-Sully looks François Ier but cannot act him, except in the love-scene in Act II, where he is very good. Got cannot play Triboulet. He is a good, comfortable old gentleman who 
could never say a funny thing or do a wicked one; and he speaks the sublime monologue of the fifth act without conviction, like a schoolboy on a speech-day. It seems to him to be the most ordinary thing in the world to have the body of a King in a sack; and he speaks those splendid lines :-

\section{'Que je suis grand ici, ma colère de feu \\ Va de pair cette nuit avec celle de Dieu,'}

as though they had no particular significance. I should like to see Coquelin or Taillade do it. Jacques Reubell said a very good thing about him in Act I, when he carries a cap and bells : 'Il a l'air d'un bon bourgeois qui parcourt le Louvre pour épousseter les meubles.' François would not have kept such a dull jester for an hour. Of course he has moments. The great scene with the Courtiers in Act III was very good. Again, he was very good in Act IV with Saltabadil when the latter asks the name of the man whom he is to murder. 'Il s'appelle le crime, et moi le châtiment.' Oddly enough he was at his best in the scene with the bystanders when the body of Blanche had been found in the sack. There he was really pathetic, and I had a genuine thrill. From my general condemnation of the whole piece I must except Mlle. Bartet, who did her best with Blanche and was very charming. But Lord! what rot Hugo makes the poor thing talk! It is almost as well that I am not going to write an article on it in the Saturday: I should feel compelled to speak against the Français as I never thought I should have to speak." Le Roi s'Amuse was a great favourite with J., and it is interesting to note that in 1904 he printed privately a very telling version of Act $\mathrm{V}$.

J.'s love for the Français (the 'Temple, as he usually called it) was a very real thing, and his first visit to the house as rebuilt after the fire was a shock to him. In January 1901 he wrote : "The spectacle presented by the house is navrant-there is no other word for it. The fire having made havoc with the one relic of the ancien régime left to us, the architect of the theatre has finished it off. The passages and vestibules remind one 


\section{2 \\ F.'s Love of the Theatre}

of a provincial railway station. Floors and staircases are of stone, the balustrades of common ironwork, the walls coloured yellow, the boxes made of light-brown oak. At the top of the grand staircase, where the statue of Rachel used to stand, and where the door was which led to the Loges des Artistes, are three cold vulgar arches of stone, and an ascenseur! The Foyer and the statue of Voltaire have been suffered to remain, but the long gallery leading out of it has been vulgarised, and the statue of George Sand has disappeared. In the house the horrid yellow pursues you, alternating with dull red. The one change that was really wanted has, of course, not been made. 'The floor is still too low, so that you cannot see the feet of the artists. The proscenium makes you shudder to look at it. A broad band of oak-leaves, evidently made of plaster, goes all round, thickly covered with yellow paint; and at the bottom two ridiculous flower-beds of sham flowers." Certainly the change, as vividly described by J. in 1901, must have been amazingly unpleasing to anyone who had known and cared for the old Théatre Français, and there can hardly have been an Englishman who knew it better and loved it better than did $\mathbf{J}$.

As to English dramatic art, I went with $J$. to plays in London less often than I did to plays in Paris. But I know certain things as to his tastes and opinions. He always loved a melodrama, and delighted in such pieces as The Silver King, The Lyons Mail, and The Bells. He was worried, perhaps unduly, by some of Sir Henry Irving's mannerisms, but not the less he fully recognised and admired the actor's genius; and it is for many reasons noteworthy that he specially admired Irving's King Lear, in which part he also had a real admiration for Mr. Benson. Mrs. John Wood, who certainly was inimitable, was a special favourite of his; and he discerned the very high, individual, and latterly very flexible talent of John Clayton before it had found full public recognition, and before he had any personal knowledge of the actor. I believe Clayton was the only actor on the English stage whom 


\section{W. H. Pollock}

he knew well in private life. Clayton once paid him a visit at Cambridge, and J.'s delight then was as unaffected and pleasing to see as was his earlier joy in the passing visit from some of the old Haymarket Company. But for Clayton he had a real friendship. As I write I am reminded of a good instance of J.'s aptness in summing up the essence of an actor's achievement in a particular part. Clayton had been cast for Dazzle in London Assurance, a part which then seemed not altogether in his line. I asked J., who had seen Charles Mathews, the original Dazzle, what he thought of it, and how it compared with Mathews's rendering. He replied, "It was a fine, well-thought-out piece of work. Clayton knew how he, personally, could get big effects, and he got them. Mathews's Dazzle was like the finest champagne; Clayton's was like the finest burgundy." I saw Clayton in Dazzle, and could imagine Mathews in the character from J.'s descriptions, and from seeing him in not dissimilar parts; and it seemed to me that the distinction could not have been better drawn than it was by $J$.

Mention of Clayton, excellent actor and excellent companion and friend, reminds me of a subject on which J. and I were wont to cap experiences, the subject being the astounding perversions of a French author's meaning that used to obtain in English "conveyances" from French playwrights. On the occasion of Clayton's visit to J. at Cambridge he took a hand in this game. J. and I offered instances, some of which I still remember. One was a special favourite of J.'s and came from a Proverbe by Musset. The French line is, "J'ai mis M. de Savigny à la porte avec son petit meuble " (a pincushion or something similar which Savigny had brought with him). The line given to the English actor was, "I have put Monsieur de Savigny at the door with his little piece of furniture." Then there was, in the English version of Les Danicheff, for " N'éveillez pas le médecin qui dort" (which of course should have been rendered "Let sleeping doctors lie"), "Do not arouse a slumbering physician." And again, among other absurdities, in 


\section{F.'s Love of the Theatre}

an English version of a French perversion of The School for Scandal is the remarkable line, "I assure you my wife shines in society like an artificial fire." When J. and I had for the time being exhausted our examples, Clayton put the final touch by recounting how once, playing a youth making love to a woman of the world, who good-naturedly laughed at him, he had to say (with an emphasis which he could not resist), "Madam, you treat me like a scholar!" Of which line the original is obvious enough.

That J. was as thorough and keen a critic of English as he was of French plays and players may be seen in the following extract from a letter written in 1895 :-

"I went last night to see Mrs. Ebbsmith. I suppose one ought not to judge so careful a work, on which the author has evidently spent months of thought and labour, at a first hearing; but I must admit that in the first place it is dull. There is no action-talk, talk, talk for three mortal hours; and talk uttered by, or about, two invertebrate persons who don't know their own minds. Mrs. Patrick Campbell acts splendidly. I had no idea what a real artist she was till I saw her in this, but her part is a thankless one; and there is no justification for the sudden change of front in the second act when she appears in an outré dress, looking like a cracker off a Christmas tree, as Freddy Bentinck said. This change should have been carefully prepared. Then again, the much-vaunted scene of the burning of the Bible fell quite flat last nightthere was no applause at all. It seemed to me that the audience had got bored with the stove, which all the characters had been fiddling at ever since the curtain went up. First the servants make up the fire; then Cleeve burns a lot of letters in it; then she and he are always sitting down in front of it, and opening and shutting the door. When you know what the great scene is to be, this wretched piece of furniture gets on your nerves."

With this characteristically keen quotation I close my personal and other recollections of J., whereof the setting 


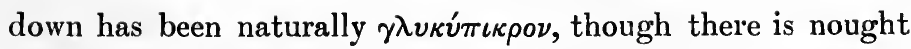
but pleasure in the thought that between him and me there was never an atom of bitterness.

There are very few subjects (bar politics, on which we agreed to differ totally) concerning the thoughts or deeds of mankind which I have not, at one time or another, discussed with J. in Paris, in London, in Cambridge, before and during his married life. Always I found these talks delightful, and never, I think, did I miss learning something from them. Whenever and wherever we were for long in company together we were pretty sure, sooner or later, "to return to Bressant," in other words to matters dramatic. On these, from the Greek tragedies and comedies to the latest farce or melodrama of the moment, his knowledge and command of illustration were unique. In conversation or argument concerning them he was always learned, constantly enthusiastic in praise or blame, often brilliant, and never tedious.

In addition to his general interest in dramatic art at home and abroad, there were three particular manifestations of it at Cambridge in which J. played an important executive part. These were the A.D.C. performances; the series of productions of Greek plays; and the regular New Theatre pieces. The first two have been alluded to elsewhere. With regard to the last, J.'s connexion with the regular drama in Cambridge goes back to the time when the more enlightened members of town and University were agitating and memorialising to get that part of the Theatres Act of 1843 repealed which gave the ViceChancellor absolute power to prohibit dramatic performances within the borough or fourteen miles thereof. It is difficult to realise at the present time the strength of the opposition to the establishment of a theatre in Cambridge. But it would appear that in the seventies many would have been found to agree with an eminent dissenting minister who in quite recent years 
256 F.'s Love of the Theatre

was heard to describe the pit entrance of the New 'Iheatre as the mouth of Hell!

It was largely due to the untiring efforts of Mr. W. B. Redfern that this state of things came to an end. By the Cambridge University and Corporation Act of 1894 the ViceChancellor was to some extent shorn of his powers, and in the following year the present New 'Theatre was built on the site of the earlier Saint Andrew's Hall, where Mr. Redfern had for some time been providing more or less regular dramatic entertainment. A company was formed to work the New Theatre, with Mr. Redfern as Managing Director. Of this company J. was a Director from its formation, and after the death of $\mathrm{Mr}$. T. Hyde Hills he became its chairman, an office to which he was elected in 1902 and which he held until his death. $\mathrm{He}$ took the warmest interest in the fortunes of the theatre, was constantly present at performances, and did all in his power to provide good plays and to put a stop to the occasional vulgarities of a small section of the audience. 


\section{APPENDIX I}

\section{J. AS SUPERINTENDENT OF THE MUSEUM OF ZOOLOGY}

The zoological collections belonging to the University are housed in the Museum of Zoology and Comparative Anatomy and in the Bird-room, and are under the control of a Superintendent, who is now elected by the Special Board of Biology and Geology. The Museum has a double origin, (i) from the collections belonging to the Philosophical Society, and (ii) from the comparative-anatomical, physiological, and osteological specimens prepared or purchased by successive holders of the Chair of Anatomy.

The Philosophical Society was founded in 1819, and received its Royal Charter in 1832. In this latter year the Society launched out and built themselves the spacious, if unlovely, house which now shelters the Hawk's Club and overlooks the old churchyard of All Saints. The house was well adapted for the Society's purpose with a Lecture-room, Reading-room, Museum, and other apartments, but its cost was beyond their means. For a time, however, the Society flourished, but, as the years passed, the number of members declined, the burden of the building expenses bore with increasing weight on the diminished membership, and in 1865 the house had to be sold. The Society and their Library were then housed by the University in the present (1912) Philosophical Council Room, and their Museum-known as the Museum of Zoology-was made over to the University.

\section{I.-The Museum of Zoology}

This Museum was fully described in the Cambridge Portfolio, 1838, by the well-known naturalist, Mr. Leonard Jenyns. Its character remained the same till its transference to the 


\section{$258 \mathcal{F}$. at the Museum of Zoology}

Museums-that is to say, it remained essentially a British faunistic collection, and, to a considerable extent, a local one. Largely it consisted of stuffed vertebrates, birds' eggs, and pinned-out insects collected in Cambridgeshire, but, as will be seen from Mr. Jenyns's account, an exception must be made to these statements when the fishes are mentioned. Mr. Jenyns writes:-

"The Cambridge Philosophical Society has been employed from the period of its first establishment in 1819, in gradually forming a Museum of Natural History. With a view to this end, it has from time to time effected several purchases, as well as received the contributions of various donors. The Museum, however, is not large; partly owing to the limited funds which can be appropriated to its support, and partly to the necessarily restricted space allotted for its reception in the Society's house. It is principally, though not exclusively, devoted to the illustration of the British Fauna. The foundation of the Museum may be attributed to Professor Henslow, who presented to the Society at its first institution his entire collection of British Insects and Shells, arranged respectively in two cabinets. Several smaller donations quickly followed, leading the Society to take an increased interest in this part of its establishment. In 1828, a spirited subscription was commenced amongst its members to assist in purchasing a most valuable collection of British Birds, for obtaining which an opportunity then offered itself. This collection had belonged formerly to Mr. John Morgan of London. It was extremely rich, especially in the rarer species. Many additions, however, have been since made to it; and the whole forms now a range of thirty large cases, which are placed round the principal room in the Museum. The birds are beautifully preserved; and the cases of sufficient size to admit, in many instances, of containing entire families. One of the cases contains British Quadrupeds. In 1829, the Society purchased a small collection of British Insects, which was incorporated with that previously presented by Professor 
Henslow. This collection, which consisted of about 2000 species, was valuable from the specimens having been arranged and named by Mr. Stephens, the celebrated Entomologist of London. Various additions in the same department have been since made from time to time by different contributors. In 1833, the Society purchased Mr. Stephens' entire collection of British Shells, contained in two cabinets and comprising a most extensive series of species as well as of individuals of each. 'The Museum has been further enriched, in the department of the British Fauna, by a collection of Birds' Eggs, presented in part by Mr. Yarrell and in part by Mr. Leadbeater; also by a collection of Fish, obtained principally on the southern shores of the island by Professor Henslow and the Rev. L. Jenyns; and by a small collection of marine Invertebrata, obtained at Weymouth by the former of the two gentlemen last mentioned.

"'The foreign department of the Museum is not extensive, consisting for the most part of single specimens which have been presented at different times by different individuals. It contains, however, a small collection of reptiles presented by Mr. Thomas Bell. It is also rich in Ichthyological specimens; having been presented some years back with a collection of fish made at Madeira by the Rev. R. 'T. Lowe; subsequently, with another collection made in China by the Rev. C. Vachell; and yet more recently, with the entire collection of fish brought home from South America and some other portions of the globe by C. Darwin, Esq., of Christ's College, the accompanying Naturalist in the late voyage of the Beagle, under the command of Captain Fitzroy. The whole of the fish above alluded to, as well as those belonging to the British collection, are preserved in spirits. They amount to several hundred species; and many of those comprised in the Darwin Collection are entirely new. Altogether, they constitute a highly valuable as well as interesting portion of the Society's Museum.

"Independently of the collections above enumerated, the Philosophical Society has made it an object to establish a 


\section{F. at the Museum of Zoology}

separate collection of the principal animals found in Cambridgeshire. This is a step of the utility of which there can be no doubt. Local collections of this nature tend to illustrate the Faunas of particular districts; and local Faunas offer the best materials for completing our knowledge of the Zoology of the whole kingdom. They also throw light upon the geographical distribution of animals. In proportion to the number of places in which such collections are established, they assist in determining the extreme range of the different species, as well as the districts to which they are ordinarily confined. In this department, however, the Birds of Cambridgeshire and a few of its Mammalia are alone as yet fitted up for public inspection; but considerable collections have been made in the other classes, which are destined one day to take their place in the Museum also.

"The Museum of the Society, and that part of it in particular which has been just alluded to, has been probably instrumental in exciting much interest in the University in the science of Zoology, and diffusing amongst its members a taste for such pursuits. Nor is the surrounding neighbourhood at all unfavourable for the researches of the naturalist. On the contrary, Cambridgeshire may be considered as rich in animal productions. From combining within itself a considerable variety of soil and situation, it adapts itself to the habits of very different species. The fens in particular are inhabited by many rare aquatic birds and insects; and some of these, previous to the introduction of the present system of drainage, were in considerable abundance. It may perhaps be interesting to mention, that the entire number of vertebrate animals found in Cambridgeshire amount to 281. Of these, 38 belong to the class Mammalia; 204 to that of Birds; 9 to that of Reptiles [and Amphibia]; and 32 to that of Fish. ${ }^{1}$

1 In the Natural History of Cambridgeshire, edited by Dr. Marr and myself (Cambridge, 1904), the number of Birds is given as 235 ; of Reptiles and Amphibia, 11 ; of Fishes, 42. The number of Cambridgeshire Mammals is not recorded. 


\section{Museum of Zoology}

The invertebrate animals require further investigation; but they probably exceed 9000 , of which the greater portion belong to the division of Annulosa."

This Collection of the Philosophical Society formed the Museum of Zoology, and was for many years kept separate from the other Collection which in the main came from the Department of Anatomy. It was at first placed in what is now the Bird-room. Judging by the Annual Reports, the Museum of Zoology was rather tiresome to manage; either the room was inadequate or the number of cabinets and show-cases insufficient. In his report for 1872, J. talks of "defects which are so serious that I sometimes think that no Museum of Zoology at all would be preferable to one so badly appointed as ours is at present." A beginning of the amalgamation of the two collections had, however, been made when, in the previous year, Mr. G. R. Crotch had brought all the Lepidoptera which the University possessed into one collection. In 1877, Fawcett's first building, which now shelters part of Zoology and Physiology, was completed, and then the Museum of Zoology, whose eastern windows had been blocked by the central staircase, was provided with a sky-light. J. reports that " it is now a very commodious and well-lighted apartment." It then occurred to the authorities to do what should have been done from the first, and the Zoological collection upstairs was broken up and incorporated with the Museum of Comparative Anatomy downstairs. The fish were stored in the galleries, and the rest of the room was given over to Ornithology. It became in fact the "Bird-room," and Salvin's Museum downstairs now became the Museum of Zoology and Comparative Anatomy.

\section{II.-The Museum of Comparative Anatomy}

The earliest Annual Report of the Museums and Lecture Rooms Syndicate is dated 1867, and from that year forward we find in these Reports a complete and lucid statement of the 


\section{F. at the Museum of Zoology}

growth of the various collections. The care of J., however, has supplemented this by a series of volumes called the "History of the Museum," in which all documents and papers connected with theInstitution have been carefully preserved and catalogued.

It had been agreed in 1865 to remove the osteological and the small invertebrate collections, together with the physiological series, from Professor Clark's Museum at the Anatomical Schools to the newly built Comparative Anatomy Museum, and this was done under J.'s supervision. It was further stated that the large skeletons required some "cleaning and mending, an operation which Mr. J. W. Clark, Fellow of Trinity College, had kindly undertaken to superintend." J. was eventually put in complete charge of the rearrangement of the collections, and on 19th October 1865 we find him reporting to the ViceChancellor in detail on the arrangements he had adopted. $\mathrm{He}$ dwelt in his Report upon the advantage of having a series of specimens illustrating comparative osteology, and the importance of the Physiological collection, which practically illustrated by a series of dissections the comparative anatomy of the "soft" organs.

In early days, until the birth of the Museums and Lecture Rooms Syndicate, the Museum was annually inspected by the Vice-Chancellor, the Regius Professor of Physic, and a few other gentlemen, a custom which dates back at least as far as 1837; and the first mention I find of J. in their Annual Reports is in the year 1856, when J. W. Clark, B.A. of Trinity College, presented two skulls of reindeer to the Museum. In 1860 he presented the skeleton of a heron, the skeleton being set up by Dr. Drosier, who stood for the Professorship of Zoology and Comparative Anatomy in 1866, when Alfred Newton was elected, and instituted at his death the Drosier Fellowships at Gonville and Caius College. In 1861 we find J. assisting his father in the rearrangement of the Osteological Department, where he labelled and determined a large number of preparations. The same year he presented to the Museum some fifty specimens which he had evidently collected. From that time onwards he 


\section{Museum of Comparative Anatomy 263}

was closely associated with the Zoological Collections, of which he was formally appointed Superintendent in the year 1866 .

The Museum of Comparative Anatomy as opposed to the Museum of Zoology (the Philosophical Society's Collections) consisted in the main of Zoological specimens, which had been gradually accumulating in the Human Anatomy Museum for the last hundred years. Sir Busick Harwood (Professor from 1785-1814) took a wide view of his subject-the Professorship is one of Anatomy, not of Human Anatomy-and lectured and demonstrated on the lower Vertebrates, some of which, having yielded up their anatomical secrets on the dissecting-table during the morning, were said to have reappeared upon his table at the mid-afternoon dinner of the period. He gathered together a considerable number of mammalian skeletons and a few stuffed specimens. His next successor but one, Dr. W. Clark (18171866), J.'s father, was very energetic in acquiring Zoological specimens for his Museum. Many he paid for himself, and from time to time he succeeded in persuading the University to increase the collections by purchase. In 1820 and 1821 he was negotiating for a collection of wax-models made by Calanzuoli of Bologna; and in 1823 the latter was paid sixty sequins. Later, Mrs. Clark also made certain wax-models for the Museum, but all these have unfortunately perished. In 1830, the "Museum Brookesianum" was broken up, and at the sale Professor Clark acquired a considerable number of specimens: these were, however, with a few exceptions, of a medical or pathological description. Four years later Mr. J. B. Milsom, then an undergraduate of Trinity College, described a hybrid between a lion and a tiger which had died in the menagerie of Mr. Atkins at Cambridge; and the animal was secured for the Museum. In the following year over $\mathfrak{L} 100$ was spent in buying specimens at Delafont's sale. These specimens were bought under the advice of Mr. (later Sir) Richard Owen. 'The same year the collection of Professor Meckel of Halle was offered to the University, but I find no record of its being bought. 


\section{Z. at the Museum of Zoology}

In May 1836 a sub-syndicate recommended the purchase of the collections of Dr. Macartney, then Professor of Anatomy at Trinity College, Dublin. The collections consisted of over 17,000 specimens illustrative of Human and Comparative Anatomy. They were bought, but, as the state of the University Chest did not justify the payment of a single large sum, it was agreed to pay Dr. Macartney an annuity of $£ 100$ a year for ten years; and shortly afterwards special regulations were submitted to the Senate for the proper care and management of the specimens. The next important accession was made in 1840, when Mr. William Swainson offered his collection of birds to Professor Henslow at a price (£320) which practically made it a gift. The money was got together by subscription. Besides the birds, which numbered nearly 3000 species, this collection comprised a considerable number of mammalian skins and specimens of reptiles and fishes, and some 10,000 insects and a few other invertebrates; also a herbarium of some value. In 1846, Captain Francis P. Blackwood, R.N., further increased the avian collections of the University by presenting a large number of birds which he had collected whilst surveying the great barrier-reefs on the eastern coast of Australia and the channels and islands of the Torres Straits. In 1863, F. B. Goodacre, who had removed his Museum of Vertebrate Animals to Cambridge, made it over to the University under certain conditions.

These, then, were the collections which formed by far the larger part of the Museum of Comparative Anatomy, and it was these which J. removed from the Anatomical Schools, and began to instal in their new quarters in 1866.

J., as I have said above, was formally appointed Superintendent in 1866, and the first Report of the newly constituted Museums and Lecture Rooms Syndicate, which had been inaugurated in the same year, appeared in $186 \%$. J. was at this time busily engaged in getting the two Museums into order, and especially in arranging the series of Fishes collected in Madeira by Mr. Lowe of Christ's College, and the large 


\section{The Physiological Collection 265}

number of specimens taken by Mr. Darwin during the voyage of the Beagle. These fishes were shortly after named and catalogued by Dr. Günther of the British Museum.

In his very first Report, J. draws attention " to the lamentable deficiencies of the Invertebrata; Molluscs are scarcely represented at all; of Crustacea there are absolutely none," in either Museum.

J. always took the greatest interest in what was termed the Physiological Collection. It consisted of specimens prepared by Sir Busick Harwood, Dr. Macartney, his father and others, and of many specimens from the Museum of the late Professor Schröder van der Kolk of Utrecht, which had been purchased by Professor Humphry and by him presented to the University. A good deal of the summer of 1866 was spent in overhauling these collections, eliminating useless or decayed specimens, and remounting and arranging the whole according to the system of Hunter, as developed in the catalogue of the Museum of the College of Surgeons. Professor Humphry drew up a most useful analysis of the whole as a guide to students.

What gave J., with his love of marine mammals, the keenest pleasure in 1866 was the acquisition of the complete skeleton of the Common Fin-Whale (Balcenoptera musculus), ${ }^{1}$ "which from its importance I cannot forbear briefly to call attention to.

"The animal was cast ashore dead, in Pevensey Bay, Sussex, during the night of 13th November 1865. It was claimed by the Crown, and sold to a company of fishermen who, after showing it for some days, sold it to a speculator at Hastings, by whom the bones were put together roughly, and exhibited for some months. Finally, at the end of May last, he disposed of them by public auction, when they became the property of the University. The skeleton is that of an adult male, 67 feet long, perfect and in excellent condition. In fact, when properly articulated and put up

1 Called in J.'s time Physalis musculus. 


\section{F. at the Museum of Zoology}

in the Museum, we shall unquestionably possess the finest skeleton of a Fin-Whale at present existing in this country."

In 1867 the Annual Report records, what it always has recorded, and what it will, I believe, always record, the inadequacy of the provision of wall-cases and cabinets necessary for storing the Natural History specimens. By this time Dr. Günther had examined the collection of fishes made by Lowe, Darwin, Vachell, and others, and determined those still unnamed, and the Swainson Collection of Birds had also been overhauled and found to be in good condition.

An epoch in the history of the Zoological Collections began in the spring of this year when Mrs. C. D. M. Strickland wrote on the 7th March 1867 to the Superintendent offering for the acceptance of the University of Cambridge a collection of upwards of one thousand bird-skins formed by her husband, H. E. Strickland, M.A., F.R.S., late Deputy Reader in Geology at the University of Oxford. In her letters she states: "My object in offering the Collection to the University is to aid professed naturalists, not to furnish a means of instruction to beginners, and still less as an additional object of interest to mere sight-seers." The offer was gratefully accepted.

The importance of housing the Swainson and Strickland Collections was such that J., in conjunction with Professor Newton, attempted to raise by subscription a sum sufficiently large to pay for the necessary cases in which to store the bird-skins. Their efforts were to a certain extent successful. They obtained $£ 382$ from private individuals, and $£ 380$ from the Colleges. In the middle of the last century, Colleges were more wont than at present (though there are still one or two honourable exceptions) to contribute of their corporate funds to University objects, for instance to the cost of these cases, or to the purchase of Collections. Possibly this was because the annual contribution to the University did not then exist, and also because in those days the Colleges were richer. The sums just mentioned, though insufficient to 


\section{Invertebrata}

provide quite enough cabinets, enabled J. to accommodate all the skins they then had, except some of the largest.

The collection of Invertebrates was also increasing, and the Superintendent was arranging for the small band of students a useful educational series, selecting his material from the Woodward Collection of Shells purchased by subscription in the autumn of 1866, from the British Insects and Molluses which had belonged to the Cambridge Philosophical Society, and from a series of Sea Anemones, Echinoderms, and Tunicates, named and selected by Professor Lütken of Copenhagen. During this year Mr. Joseph Gedge, M.B. of Gonville and Caius College (the founder of the Gedge Prize), who died at Khartoum whilst acting as medical officer to Sir Samuel Baker's Egyptian expedition, and Mr. L. Ewbank of Clare College, were engaged, the one in making skilful and minute dissections and anatomical preparations, the other in arranging Woodward's Molluscs. Dr. James Murie, at that time Prosector to the Zoological Society of London, was most useful in supplying the Museum with portions of animals who had died in the Society's Gardens. The Museum was indeed beginning to attract attention, and many of the students were contributing occasional specimens. Nothing pleased J. more than the spontaneous visits of shy but inquiring undergraduates. Many of them, like Mr. C. F. Tyrwhitt Drake and Mr. T. E. Buckley of Trinity, subsequently became generous benefactors to the Collections.

In 1868, Mr. W. Savile Kent, who had rearranged the Invertebrate Series for the Museum of the College of Surgeons, was engaged in helping $J$. to prepare a catalogue of the Cambridge collection of Invertebrata in the Museum of Comparative Anatomy; he also rearranged and named the series of Corals. This year J. writes about the vertebrate part of his collections with pride :-

"I must especially particularise the almost perfect skeletons of a male and female Solitaire (Pezophaps solitaria), temporarily deposited by Mr. (afterwards Sir Edward) Newton of Magdalene College, Colonial Secretary of Mauritius. This bird, whose 


\section{F. at the Museum of Zoology}

geographical range was limited to the island of Rodriguez, and whose very existence, although described by François Léguat in the sixteenth century, was more than once called in question, has now been restored to us through Mr. Newton's perseverance in visiting the island and recovering a large series of its bones from the caves in which they had lain buried. We also have acquired on the same terms the most complete known skeleton of the Dodo (Didus ineptus) put together from bones obtained by Mr. Newton in Mauritius, as well as casts of most of the separate bones of the Dodo and Solitaire preserved in other Museums; and Professor Rolleston has lately given us photographs of the Dodo's head and foot at Oxford; so that we now possess complete materials for the comprehension of the osteology of these remarkable forms."

Numerous other osteological specimens were added about this time, especially a very large series of semi-fossilised bones of old fen forms: Bos, Cervus, Sus, and Equus. These were presented by Mr. James Carter, who for many years had been studying the extinct fauna of the district.

By 1869 the Swainson and Strickland Collections had been arranged; Mrs. Strickland herself spent many days in the museum, labelling and sorting the birds and compiling a catalogue. These Collections amounted to nearly 6000 specimens, referable to over 3000 species, and were amongst the few large Collections accumulated by a private person. Mr. Selby's Collection of bird-skins, amounting to 1400 in number, those of the Blackwood Collection, the Collection belonging to the Philosophical Society, with some other smaller Collections, were now all brought together, sorted and fitted into drawers. Mr. R. B. Sharp, F.L.S., of the British Museum, was occupied in naming and cataloguing the birds; and Mr. P. L. Sclater, F.R.S., and Mr. Osbert Salvin of Trinity Hall, most kindly examined the Collection and took an active part in its rearrangement.

J.'s chief zoological interest was always with marine mammals, and he now records a present by Professor Humphry of a 


\section{The Library}

very large and fine skeleton, " unquestionably the finest in this country, of a sea otter." This year, too, came a valuable series of Tasmanian Marsupials, presented by Mr. M. Allport of Hobart Town, many belonging to forms which were rapidly becoming rare and threaten soon to be extinct. In 1870 Charles Darwin presented the great majority of the collections of Invertebrata made by him during the celebrated voyage of the Beagle; and the Museum further received a valuable collection of reptiles, birds, and mammals collected by Mr. C. F. Tyrwhitt Drake of Trinity College in the Sinaitic Peninsula, where he had been exploring in conjunction with Mr. E. H. Palmer of St. John's College. In the following year Palmer became Lord Almoner's Professor of Arabic, a post which he held until his tragic murder in 1883.

About this time (1870) J. was able to secure the assistance of Mr. T. W. Bridge, a student at 'Trinity College, who was subsequently Professor at the Mason College, later the University of Birmingham. The appointment, if it was an appointment, must have been unofficial; as it was not until seven years later that the University established an officer under J., who was called Curator in Zoology. Mr. Bridge was at first largely occupied with dissecting and mounting preparations.

In the same year an attempt was made towards the formation of a Museum library, which has since grown into a very considerable and a very valuable collection of books. A Grace of the Senate was passed, by which the Syndics of the University Library were allowed to deposit duplicates of works on natural science at the New Museums. This library has been immensely increased in size and eren more in value, by the Buckley Collection of books on Africa, at present temporarily placed in the Philosophical Library, and by the very valuable Newton Library. These with the Balfour Library, the Strickland Library, and the Norman Library, make altogether a collection of books on animal natural history of inestimable value, and it is to be hoped that they will soon be consolidated under one roof and under the care of one librarian. 


\section{F. at the Museum of Zoology}

The Hepburn Collection, got together by Mr. James Hepburn of St. John's College, who had long lived at San Francisco, was generously given to the University by his executors in 1870, in fulfilment of his well-known wish. The collection was illustrative of the fauna of the Pacific seaboard from Alaska to Panama, and contained, amongst other rarities, two complete skeletons of the Northern Fur-seal (Callorhinus ursinus); these, as J. records, " are of very great value, being, as far as I know, the first skeletons of this seal that have been acquired by any European museum." In the same year J. records with pleased surprise the continued increase in the numbers of students frequenting the Museum. He was particularly good at talking to and interesting the junior members of the University, at any rate if he took the least liking to them. He had the knack of making them think he really wanted to see them, and to hear their opinions and what they had to say.

In the following year-1871-an arrangement was entered into with Mr. G. R. Crotch of St. John's College to determine and arrange the University's collection of Insects, which had just been largely increased by the acquisition of the collections of British Lepidoptera formed by the late Messrs. J. and T. Brown of King's Parade. Mr. Crotch presented his own fine collection of Coleoptera, and the University acquired from him collections of the British Diptera, Hymenoptera, Trichoptera, and Hemiptera.

An entirely new movement in the teaching of Zoology in the University was begun in the same year (1871). ${ }^{1}$ J., with the assistance of his friend Mr. Bridge, began for the first time to give courses of practical work. As he himself writes:"It is impossible to teach Comparative Anatomy efficiently

1 Similar practical work in Zoology was commenced by Huxley in London the following year. "In 1872 the removal of the School of Mines from Jermyn Street to South Kensington gave the long-desired opportunity of completing his plan of instruction, by enabling every student to examine for himself, in the laboratory, the types described in the lectures" (Dict. Nat. Biog.). 
without practical work; by which I mean the dissection of Vertebrates and Invertebrates by the students under proper supervision. Without such facilities (which are provided in a most thorough and complete manner at Oxford), there is a danger of students either gaining their knowledge second-hand from books, or of their being obliged to have recourse to instructors, who would have to provide educational appliances apart from the Museum, thereby defeating the objects of the University in creating and supporting the large and increasing collection that we now possess. With the view of supplying this want-and of supplementing the lectures of Professor Newton by a course of instruction that lectures cannot possibly convey-I have, during last term and this, commenced a class for practical work, presided over by Mr. Bridge and myself, which will in a short time, I have little doubt, become a large one. For this, however, there is but one room available, that assigned to myself: a room quite unsuited to the reception of a number of students; I venture, therefore, to urge upon the University the immediate necessity of considering the question of how to provide additional accommodation for this purpose."

This first course of practical demonstrations in Comparative Anatomy met with Professor Alfred Newton's entire approval, and he records his satisfaction that it had been undertaken.

It has hardly been recognised that $J$. in this matter started a new era. There was to some extent, in 1871, practical work in Chemistry and a little in Mechanism under Professor Willis, but except the arid inspection of the specimens comprising the Hortus siccus and periodic visits to the Botanic Garden, there was nothing on the biological side, if we omit Human Anatomy, and only this year (1871) at Cambridge were the "opportunities for practical anatomy" sufficient to allow the Royal College of Surgeons to recognise our School. But there was no practical work in Physiology or Physics or Pathology. Previous Professors of Anatomy had, of course, dissected various animals whilst their students looked on, but now for the first time students actually dissected the animals them- 


\section{F. at the Museum of Zoology}

selves, and saw what they themselves had displayed in the specimen; they were also encouraged to make preparations of a permanent nature.

During the following year (1872) J. records : "The Museum has now been more used by students than in any preceding year. The classes for Practical Work and the Demonstrations in Comparative Osteology have been well attended, and the appointment of a Demonstrator will probably increase the number of learners. But all the success of directing students only makes the need of proper rooms to teach and work in the more obvious."

Professor Newton, in his report on this year, strongly urges upon the Senate the necessity of taking immediate steps for the appointment of a Curator who, under the Superintendent, would have charge of the Zoological Department of the University. The conditions of the collections he held were falling behind, and much that should be displayed was still unavailable.

The year 1873 was marked by one of the greatest additions the Museum of Zoology has ever received-the MacAndrew Collection of Shells. Not only did Mr. Robert MacAndrew, F.R.S., bequeath the whole of his collections of marine Molluscs, dredged in the course of many voyages undertaken solely for this purpose, but he left to the University a valuable library dealing with Conchology, and his widow generously presented to the University the cases in which the collections were contained. Mr. MacAndrew had himself catalogued his collection, which contained over 2000 genera and nearly 16,000 species. The special object of Mr. MacAndrew's researches was the investigation of the growth of shells from the earliest stage of the Mollusc to the adult: in consequence he always sought to obtain a long series of each species; in many cases twelve to twenty examples were collected and arranged, so that the total number of specimens of the collection amounted to some 200,000. As Mr. MacAndrew gave up his leisure to dredging expeditions wholly devoted to obtain- 


\section{The Strickland Curator}

ing Mollusca in the North Sea, the Mediterranean, and the Gulf of Suez, his specimens were obtained fresh, and as a rule alive. The precise locality was always noted at the time of capture.

'The Narwhal with two tusks, which is so conspicuous an object in the Museum of Zoology, was now articulated and put on show. J. records that " it is one of the finest in existence. It was taken on the coast of Greenland in 1868, and was presented to the Museum by my father a few months before his death."

A Demonstrator to the Professor of Zoology and of Comparative Anatomy had been established in March 1873, and Professor Newton nominated J.'s unofficial assistant, Mr. T. W. Bridge, to the post. The nomination was confirmed by the Vice-Chancellor. Professor Newton, so far as I am aware, never took part in actually demonstrating to students, though he was most kind in showing members of his class specimens of bird-skins, birds' eggs, etc. Still, he heartily approved of practical work, and most generously lent his Demonstrator to carry on this side of the subject.

Early in 1874 the Senate accepted the offer of Miss Frances Strickland of Apperley Court, to found a Curatorship for Birds at a stipend of $\mathfrak{E} 150$ per annum, in memory of her brother. Mr. Osbert Salvin, M.A., of Trinity Hall, son of the architect, was appointed the first Curator. This materially lightened the work of the Superintendent, and henceforth he was to a great extent relieved of the Birds. As is well known, Professor Newton had made a special study of this class of Vertebrates, and was all his life continually presenting specimens to our Ornithological Collections. (n the foundation of the Strickland Curatorship he presented over 600 skins. 'The new Curator, Mr. Salvin, at once set to work to catalogue the Strickland Collection, a task which was materially aided by Mrs. Strickland's liberality in presenting a considerable portion of her library to the Museum.

Mr. G. R. Crotch, who had unhappily died young, be- 


\section{F. at the Museum of Zoology}

queathed in 1874 his collection of European Coleoptera in 152 boxes to the University, and J. mentions this year, for the first time in his Annual Report, Mr. F. M. Balfour of Trinity College, who had sent numerous specimens from the Bay of Naples. J. himself had spent the early part of 1874 in Algeria, and had brought back with him collections of skulls, skins, and skeletons, and also specimens from the seashore. The former were greatly augmented by the acquisition of seventeen skeletons of African mammals, presented by Mr. T. E. Buckley of Trinity College, who was now travelling in South-East Africa.

The classes of students continued to be well attended, the numbers averaging about twelve a term. Zoology was evidently beginning to flourish as a practical subject, though both teachers and taught were handicapped by the demonstrations being still held in J.'s private room. 'The consequence to him personally, he plaintively writes, is "complete exclusion from the room I was formerly suffered to occupy." He had now to content himself with a table in the Museum. In 1875 an additional class was conducted, under the direction of $\mathrm{Mr}$. F. M. Balfour, and Mr. A. M. Marshall of St. John's College, later Professor at Owens' College, Manchester. Great difficulty was, however, experienced in accommodating the students who attended these classes and those of the Demonstrator of Comparative Anatomy, but hope was entertained that adequate room would be found for them in a new building, for which the Museums and Lecture Rooms Syndicate had been authorised to obtain tenders.

In 1875, Mr. J. F. Hamilton presented his entire collection of bird-skins, over 1400 specimens of upwards of 1000 species, at least a third of which had been hitherto unrepresented in the Collection; and Mrs. Strickland added to the list of her numerous gifts by sending the remainder of her husband's Ornithological and Scientific Library, consisting of over 400 volumes.

J.'s work during the year 1876 was greatly interrupted and interfered with by the demolition of his two work- 


\section{Curators of Zoology}

rooms to make way for the new buildings now being put up under the direction of Mr. Fawcett, which were to afford the much-needed increase of space. The Trustees of the British Museum this year sent a large number of duplicate specimens, collected in the Southern Seas by the Transit of Venus expedition, and Professor Agassiz of Harvard University presented a long series of Fish, illustrating seventy genera, so that it is not surprising to learn that the "principal work of the year has been in the rearrangement of the Fish."

The new buildings just mentioned, which had been commenced in the Long Vacation of $\mathbf{1 8 7 6}$, were partially completed and occupied in 1878. There had been a considerable delay due to the collapse of a concrete floor on the topmost story.

In the spring of 1877 the post of Curator of Zoology was established and J. looked forward to a lightening of his work. But Zoology was then a fast-growing subject in these islands; teachers were badly wanted, and other careers attracted the Curators. The first three holders of the post were "birds of passage," and annually the post had to be refilled. The first Curator (1877-8) was J. F. Bullar, B.A., of 'Irinity College, who devoted himself with much energy to the Invertebrate collections. Subsequently Mr. Bullar adopted a medical career.

Professor Humphry, Professor Newton, and J. were now housed in the private rooms on the ground floor of Fawcett's building which they occupied for many years. Professor Newton at that time used the room now (1913) occupied by myself. Professor Humphry had the room now labelled "Newton Room," whilst J. had the one now occupied by Mr. Doncaster, the present Superintendent of the Museum of Zoology. But as neither the workrooms on the second floor nor those on the ground floor were nearly ready, the department was for some months in a state of great confusion. In September $1877 \mathrm{Mr}$. Salvin first occupied the private room on the second floor which has ever since been assigned to the Strickland Curator. Almost opposite him Professor Humphry was at that time holding his classes in microscopy in one of the two large class rooms facing 


\section{$276 \mathcal{F}$. at the Museum of Zoology}

north. Mr. Balfour occupied the other and also the eastern room overlooking Corn Exchange Street. Mr. Bullar and Mr. Bridge occupied the two rooms which have been now thrown together to form our present Insect Room.

In 187\%, the Prince of Wales gave to his old University the skeleton of a fine tiger which he had shot during his recent visit to India, and Mr. R. Lydekker of Trinity College presented a valuable collection of Indian mammals. J. also records that the Alaska Commercial Company, to whom the Government of the United States had granted the right of obtaining sealskins from the Pribylov Islands in the Bering Sea, had been good enough to present to the Museum skins and skulls of the male, female, and pup of the Fur-seal.

Mr. Bullar resigned the office of Curator in Zoology in the Easter term of 1878, and his successor was Mr. F. J. H. Jenkinson of 'Trinity College, now University Librarian, who only held the office for a few months. He worked chiefly at the Insects, and after his resignation proposed to examine and add to the collection of Micro-Lepidoptera. As I shall narrate elsewhere, ${ }^{1}$ the new rooms of the department of Zoology and Comparative Anatomy had hardly been occupied when part of the top concrete floor fell, and carried with it the intervening floors as it crashed towards the ground. An inquiry was held into the stability of the building, and it was finally resolved to remove almost the whole of the concrete floors and roof. The alterations were completed by the end of January 1879 , and J. took possession of his workrooms shortly afterwards. He reports: "They are extremely convenient in all respects, and the system of warming and ventilating, severely tested by the cold of last winter, has been found to work well."

On more than one occasion J. mentions, in his Annual Report, his assistant, William Stubbings, who for many years was a well-known figure at the New Museums. He made rather a speciality of the Fens, and from time to time presented complete skeletons of fossil mammals, which he had found 
himself. In 1879 he gave the Museum a nearly complete skeleton of a Red Deer, semi-fossilised.

Although I do not think that at this time J. was actually engaged in teaching, he evidently took a keen interest in the practical classes he had started, and he notes that both $\mathrm{Mr}$. Balfour's elementary and advanced classes continued to grow. In 1878 they were attended by two Americans, the now distinguished Professors H. F. Osborn and W. B. Scott, who were then members of the University, and by two or three ladies.

During the Long Vacation of $1879 \mathrm{Mr}$. A. C. Haddon of Christ's College, now University Reader in Ethnology, was appointed Curator in Zoology, and he at once took up the arrangement of the Collection at the point where Mr. Bullar had left it; he specially devoted himself to arranging the collection of bones of the extinct land-tortoises of the Mascarene Islands, which had been given to the University by Edward Newton. He also rearranged and classified the Calenterata, the Echinodermata, and the Brachiopoda. Although Professor Bridge had by this time been appointed to his Chair at the Royal College of Science in Dublin, he spent the summer and autumn in overhauling the fishes, always his special hobby, and in making a large series of their skeletons, and other preparations. Owing to the kindness of Professor Flower, the Museum of the Royal College of Surgeons presented this year a large specimen of the skeleton of a male Crocodile, killed in Nubia by the Hon. Charles P. F. Berkeley, and J. was again successful in obtaining a skeleton of one of his favourite marine mammals, the whitebeaked Bottle-nose Lagenorhynchus albirostris. It must here be mentioned that $J$. possessed a very complete collection of books on Whales, in all languages and of all periods. This year also the skeleton of the Bison bonasus, which had been presented by the Emperor of Russia, through the good offices of J.'s father-in-law, Sir Andrew Buchanan, British Ambassador at the Russian Court, was articulated and placed in the Museum. The frequent occurrence of this genus in the drift 


\section{F. at the Museum of Zoology}

in the neighbourhood of Cambridge, and the fact that the skeletons of the Urus (Bos primigenus) are found from time to time in our Fens, recalls the fact that these two species ranged in Cæsar's time over the whole of Central Europe.

In 1880 the two rooms in the central block of the building, in which at first the teaching of Zoology and Physiology had been carried on, were, by the removal of the archway to the east, thrown into one, and the Council of the Philosophical Society then submitted a proposal to place their Library there, as the nucleus of a Central Scientific Library. The University accepted the offer of the Council of the Society, and the Philosophical Society's books were in September 1881 removed into the large room on the ground floor, where they now are. The University on its side undertook to provide a certain portion of the stipend of a Library Clerk, and one of the most useful institutions in the scientific life of Cambridge was in working order by the end of the year. From that day onwards the Library has been of ever-increasing value, both to students and to teachers.

The Curatorship in Zoology was, for reasons I have already given, ${ }^{1}$ a post which no one held for long. In the autumn of 1880, Mr. A. C. Haddon resigned and was appointed to the Professorship of Zoology at the Royal College of Science at Dublin, in succession to Professor Bridge, who had accepted a Professorship at Mason's College, Birmingham. Mr. Haddon had especially devoted himself to the exhibited Collection of Invertebrata, and had illustrated many of them with coloured drawings. He was succeeded by the Rev. A. H. Cooke, Fellow of King's College, now Headmaster of Aldenham School, and a specialist in the Mollusca, who immediately set to work to overhaul, re-name, and re-catalogue the Woodward Collection of Molluscs, and with these he incorporated the shells collected by Mr. Hepburn, mainly from the West Coast of North and Central America. The Collections were differentiated by means of specially coloured labels.

1 See p. 275. 
During the year $1880 \mathrm{~J}$. was especially occupied with setting up the series of preparations illustrating the Anatomy of the Manatee, a specimen of which had been presented by the Directors of the Aquarium at Brighton. He was also occupied in articulating a skeleton of the Musk Ox brought home by the North German Polar Expedition eight years before.

The year 1881 was made memorable by a fire which broke out owing to the accidental overflowing of some ignited spirit in the spirit room. A porter, however, succeeded in extinguishing it, and the damage was confined to the room in which it had broken out. The outbreak of this fire naturally aroused the interest of the authorities, who awoke to the fact that hundreds of gallons of spirit of unknown inflammability, containing specimens, were stored in the Museum of Zoology. A sub-syndicate, of which Coutts Trotter and J. were members, undertook to investigate the matter. J., who maintained that the spirit would not ignite, applied a match to some 70 per cent. spirit in a bowl. The spirit ignited, the bowl burst, the flaming spirit flowed on the floor and over Coutts Trotter's and J.'s trousers. The ample folds of Coutts Trotter's frock coat helped to save J.'s legs though his trousers were burnt. The fire spread through the floor to the ceiling of the Physiological Laboratory below. The alarm was given, the local fire brigade arrived, and those members of the University who assisted in saving the building tell me that the burly form of the Vice-Master of Trinity without a coat, and the active form of J., clad in his old bowler hat, his cross-breasted tweedcoat, elastic-sided boots, and what the hosiers call "gent's stout merino pants," directing the operations of the Town fire brigade, was a sight indelibly engraved on their memories. The fire was soon extinguished and J., who bore his rather serious burns with his usual courage, and Coutts Trotter went home in blankets and four-wheelers.

About this time J. added to our collection of marine mammals a skeleton of a Ringed Seal, a Bladder-nosed Seal, and a Polar Bear, all presented by Captain Gray of Peterhead, 


\section{F. at the Museum of Zoology}

who had taken particular care in the killing and the preparation of these specimens, so that not a single bone was missing. The Museum was also enriched about this time by a fine series of casts of extinct mammals from the Paris Museum. Sir John Phear also presented a skeleton of an Indian Elephant, and through the kind exertion of Sir Joseph Fayrer, a skeleton, less perfect, of the same species was sent from Calcutta. Lastly, Mr. Osbert Salvin, the Strickland Curator, reports that he has at last finished the catalogue of the Strickland Collection, which made an octavo volume of some 650 pages, and upon which he had been engaged almost since his appointment in 1874 .

When I came up in 1880 a class for Zoology was held in the top room of Fawcett's first building, facing east and overlooking Corn Exchange Street, which is now (1913) used for a Chemical Class Room by the Department of Physiology. Here we used to spend our time cutting Amphioxus, embedded in cocoa-butter, into little slices under the supervision of Mr. Balfour and of Mr. Adam Sedgwick. There were then no means of sticking the sections in series on a slide, so the thin slices had to be mounted, a few at a time, on a separate microscopic slide, and the labour was considerable. It was in this room a year or two later, when I first began to teach, that I heard our head Laboratory Attendant, Mr. Brockett, on behalf of a pupil from one of the Ladies' Colleges, repeatedly attack Adam Sedgwick, who was at the moment engaged in a dissection which he felt he could not, at the moment, relinquish. After a third or fourth interruption Adam, whose temper was in those days always within easy call, said, "Oh, tell Miss "Chose' to go to the Devil." I was not best pleased a moment later to hear Brockett, who is always a diplomatist, saying to the lady, "Mr. Sedgwick, Miss, thinks you'd better see Mr. Shipley."

On 31st May 1882, Mr. Balfour had been appointed to the Professorship of Animal Morphology, which had been especially created in recognition of the great work he had done on that subject. By this time his classes were very 


\section{The Indian Elephant}

considerable in size, the elementary class having reached fifty, while the advanced class numbered over twenty.

During $1882 \mathrm{~J}$. was busy setting up the skeleton of Sir John Phear's elephant, and the following extract from his report is typical of the care he took to chronicle the origin of Museum specimens :-

"The skeleton of a male Indian elephant, the arrival of which was mentioned last year, has been cleaned and arranged in the Museum; in consequence of the care with which the bones were prepared for transmission to Europe, under the direction of Mr. A. Haly, of the Colombo Museum, the skeleton is complete, and therefore far more interesting and instructive than those usually exhibited in Museums. The animal was shot by a member of the Ceylon Civil Service, who has most kindly sent me the following extract from his notebook respecting it:- 'The Yatiantota Tusker, a notorious and proscribed rogue elephant (bull), that had done much damage to life and property. It was shot 6th February 1881, at Yakkela Kele ("forest of the devil's stream "), near Malalpola, eight miles from Ruanwela, in the Kegalle district, Western Province, Ceylon. Height, 9 feet; tusks, 4 feet $11 \frac{1}{2}$ inches, and 4 feet 10 inches outside curve-weight, 75 lbs.' Mr. Y. has retained the tusks as a trophy, but I have every hope of obtaining casts of them." 1

In $1883 \mathrm{Mr}$. Salvin resigned the position of Strickland Curator, and to J.'s great regret left Cambridge; he was succeeded by Dr. Hans Gadow, and J. in his report mentions that Dr. Gadow had already begun making dissections and introducing new methods.

After Professor Balfour's tragic death in July 1882, Professors Humphry, Newton, and Foster, and J. addressed a letter to the Vice-Chancellor, in September, urging the necessity of carrying on the work which he had so wonderfully

${ }^{1}$ As Mr. Y., possibly owing to a deficient knowledge of Zoology, retained the more valuable part of the skeleton, the tusks, it seems well to suppress his name. 


\section{F. at the Museum of Zoology}

begun. 'They suggested that the general supervision of the class should be entrusted to Mr. Adam Sedgwick, who had been Balfour's demonstrator for nearly five years, and had had charge of the class during the Lent and May Terms, when Professor Balfour had been ill. This was accordingly arranged, and Mr. Sedgwick was able to secure the assistance of Mr. Walter Heape of Trinity College, and of Mr. W. F. R. Weldon, B.A. of: St. John's, as demonstrators. Dr. Hans Gadow then began the lectures, which are happily still given, on the Vertebrata. Mr. R. Threlfall and Mr. W. H. Caldwell of Gonville and Caius College were then at work on their new automatic microtome, and the latter was requested by Professor Newton, whose demonstrator he was, to help with the advanced lectures. $\mathrm{Mr}$. Sedgwick, in his first report, records the generous action of the family of Professor Balfour, who gave to the Morphological Laboratory not only his very valuable scientific outfit, but also his comprehensive Zoological Library.

In 1883, the Museum received two collections of the greatest importance. One was a gift from Mr. H. B. Brady, F.R.S., of his series of Foraminifera, "possibly one of the most extensive collections, taken all round, at present existing, the result of about twenty years' work on that group of animals." This collection arrived in instalments, and contained not only recent forms, but a large number of fossils and models.

Towards the end of the same year the University found the money to purchase, at a figure which hardly represented the value of the jars and spirit, the specimens illustrating the fauna of the Bay of Naples, which had been sent by Dr. Anton Dohrn, of the "Stazione Zoologica" of Naples, to the Fisheries Exhibition held that summer in South Kensington. I well remember J.'s kindness in sending me up to negotiate for the purchase and to arrange for the packing up of the Collection, and I vividly recall the impression of infinite dreariness which an Exhibition produces on the lay mind when it is in the process of being dismantled. I had lately returned from working at Naples, and that is probably why he 


\section{The African Elephant}

selected me. The Collection contained nearly three hundred species of invertebrates, and thirty-eight species of fish. In many cases numerous specimens represented the single species. They had all been selected as "show" examples, were beautifully preserved, and certainly added greatly to the invertebrate side of the Museum. The rearrangement and remounting for display of the Dohrn Collection extended over two years.

About the same time J. obtained from the National Museum of Washington two models, one of the Beluga or White Whale, and the other of the Common Dolphin, and the skeleton and several skulls of Australian cetaceans from Professor Liversidge of Sydney, who had before befriended the Museum. He also articulated and exhibited the skeleton of a Hyperoödon from the Faroes, and the skeleton of a Ca'ing Whale (Globicephalus melas) from Tasmania.

In 1884, the Museum received a fine adult Echidna (Proechidna bruijnii) from the Arfak Mountains, New Guinea, and also specimens of Ovis nivicola and Tarsius spectrum, which had been obtained by Dr. Guillemard in the course of his cruise on the yacht Marchesa in the Eastern seas. Till lately the firstnamed species had been unrepresented in English museums, and J. was able both to prepare the skeleton and to mount the skin. In 1884, a complete specimen of an African elephant, shot by Mr. Walter Heape in the Knysna forest, arrived at the Museum, although it was not set up till the following year; and the skeleton of the Red Deer (Cervus elaphus), which had been found by William Stubbings ${ }^{1}$ in Burwell Fen, was now placed in the Museum.

Dr. Gadow, who was constantly working at the Bird Collection, reports this year the addition of 89 species, collected in Natal, from Major H. W. Feilden. He records that the total number of specimens in his custody exceeded 7000, and that the number of species under his charge amounted to some 4800 , or more than one-third of the species at that time known to science.

${ }^{1}$ See pp. 276, 277. 


\section{F. at the Museum of Zoology}

By the end of 1885 the arrangement of the Dohrn Collection had been completed. Before then I had been appointed Demonstrator to the Professor of Zoology and Comparative Anatomy, and I had spent many afternoons assisting J. with the rearrangement of these collections. Of course it must be remembered that J.'s stipend as Superintendent, like so many stipends in this University, was exiguous. He never was and was never expected to be a "whole timer." He looked in for a couple of hours a day, supervised his assistants, made us all keen, and rushed off to other work. The additions to the Museum were this year numerous and valuable; amongst them were a two-horned Rhinoceros and the skeleton of a Grampus from the Australian seas. A fine group of Birds of Paradise, also obtained from Dr. Guillemard, showing the interesting differences of sex and age, was now being set up in the Bird Room, and a series of typical preparations, illustrating in a comparative way the various organs of birds, was being arranged by Dr. Gadow.

During the Long Vacation of 1886, J. began the task of rearranging and cataloguing the whole of the exhibited portion of the Invertebrata, in which task he was helped by Mr. S. F. (later Dr.) Harmer of King's College. It was at that time proposed to issue the catalogue, but this has never been done. Its preparation served a useful purpose, however, in revealing numerous hitherto unnoticed gaps in the collections. These were, as far as possible, filled up, and the catalogue, though unprinted, has been invaluable for reference.

Mr. Brady spent part of the summer of 1886 and 1887 in arranging the magnificent series of Foraminifera which he had presented to the University, setting up for exhibition those which he considered most suitable to a students' series. Each specimen was beautifully mounted, and illustrated by the enlarged drawings which had embellished his report of the Challenger Foraminifera.

The Strickland Curator now presented to the Museum a large collection of amphibia and reptiles which he had 


\section{The Pevensey Whale}

got together during the previous three years in Portugal. These had formed the basis of an interesting paper which he had prepared on the geographical distribution of animals in that part of the Peninsula. About this time Sir Julius von Haast enriched the Museum by a series of bones of the Moa (Dinornis), from the Museum at Christchurch, New Zealand.

The skeleton of the African elephant shot by Mr. Heape was now placed side by side with the Indian elephant in the centre of the Museum. They are overhung by the skeleton of the Pevensey Whale (Balaenoptera musculus) mentioned in J.'s first annual report, dated 1867. The expense and the care required for mounting so huge an object had caused almost indefinite delay. At length Dr. Harmer, J.'s successor as Superintendent, with the aid of Mr. W. E. Dalby of the Engineering Laboratory, and $£ 100$ from the Reserve Fund, mounted the whale in 1896. Nothing is more striking in our Museum, or more demonstrative of the enormous size to which marine mammals may attain, than the fact that, as you look down from the gallery of the Museum at these three monsters, you become aware that the skeletons of the two elephants could almost be placed side by side within the ribs of the whale.

The Syndicate had lately made a special grant for books for the Curator in Zoology, who was steadily working at the MacAndrew Collection, as to which he reports:- "It is not too much to say that probably no finer collection of European shells-in the sense of being practically useful in illustrating and establishing variation of species-exists in this country. The British Museum has nothing to compare with it." Mr. H. M. Gwatkin, now Dixie Professor of Ecclesiastical History, who had made a special study of the radulas or lingual ribbons of Molluses, was finding and describing many new examples amongst the dried remains of animals which formed part of this collection.

In 1886 , too, came a great increase in the number of birdskins. Largely through Mrs. H. E. Strickland, the University was able to acquire a very considerable portion of the magni- 


\section{F. at the Museum of Zoology}

ficent Collection of birds belonging to Sir William Jardine, Bart. The total number of specimens received amounted to over 2000 , representing 900 species, of which 480 were new to our collections. Mr. Gurney further presented 42 species, and Professor Newton also added nearly 500 species on his own behalf. Dr. Gadow reports that after this influx of birds, he had nearly 20,000 specimens under his charge, representing about 5000 different species, or nearly half the species of birds known to exist.

During 1887 portions of the skeleton of the Steller's "Seacow" (Rhytina gigas) was received in exchange from the United States National Museum at Washington. It formed the subject of a most interesting historical sketch ${ }^{1}$ by $J$. of the discovery and extermination of this remarkable mammal. As an example of the careful way $J$. used to describe in his annual reports important additions to the Museum, I here quote his account of the skeleton of the Rhytina, first exhibited in 1888 :-

"The principal addition to the Museum is the skeleton of the extinct Northern Manatee (Rhytina gigas). Our knowledge of this huge Sirenian, which was restricted to Bering's Island, off the coast of Kamschatka-is due to the German naturalist, George William Steller, who accompanied Bering on his last voyage. Their vessel was wrecked on the island, then uninhabited, 5 November 1741. The Manatee was at that period abundant all round the coast, but, after Steller's return, Russian hunters, excited by the prospect of obtaining large cargoes of skins of Fox, Sea Otter, and Sea Lion, with which the island and those near it abounded, began to fit out expeditions. Their vessels usually wintered on Bering's Island, ' in order to procure a stock of salted provisions from the sea-cows (Manatees) and other amphibious animals that are to be found there in great abundance.' In consequence of this wholesale destruction, the Rhytina became extinct in or about 1768 .

"Steller's description of the animal was read to the St.

1 Proc. Cam. Phil. Soc., vi., 1889, p. 340. 


\section{The Rbytina}

Petersburg Academy in 1749; but he had been unable to bring home any specimens, and all efforts to obtain bones failed until 1844, when a broken skull, obtained on Bering's Island, was brought to Professor Brandt. At present the island is let by the Russian Government to the Alaska Commercial Company, by whose permission the authorities of the National Museum at Washington, U.S., have caused diligent search to be made for bones of Rhytina, with considerable success.

“As was briefly recorded in last year's report, Professor Spencer F. Baird, at the instance of Professor Newton, sent us such parts of a skeleton as could be spared for exchange. 'The bones received were the following: skull; third, fourth, fifth, sixth, eighth, ninth, tenth, twelfth, thirteenth, fourteenth, fifteenth, sixteenth, seventeenth, dorsal vertebræ; second and third lumbar vertebræ; fifth, seventh, eighth, ninth, thirteenth, ribs of the left side; fifteenth, seventeenth, ribs of the right side; right humerus; right radius and ulna. As it would have been impossible to articulate this series in such a manner as to give any idea of the skeleton, I determined to obtain restorations of the missing bones. Casts of the cervical vertebræ and of one scapula were purchased from the late Dr. Damon of Weymouth, the rest were modelled from the nearly complete skeleton in the British Museum. The whole restoration of the hands is conjectural, no portion of these limbs having been as yet discovered. The skeleton, as mounted in our Museum, is eighteen feet long." Later Dr. Guillemard presented to the Museum the ear-bones which he had collected in Bering's Island.

At the beginning of 1888, Mr. C. H. Russell, writing on behalf of his mother, Lady Caroline Russell, offered to the University the Collection of British Birds' Eggs made by the late Mr. J. P. Wilmott, and bequeathed by him to Lady Caroline's husband. This collection contained one specimen of the Great Auk's egg, the one figured by Mr. Hewitson. I do not know whether anyone except Professor Newton knew at that time how many Great Auk's eggs there were in the 


\section{F. at the Museum of Zoology}

University collections. We used (a favoured few) to be shown from time to time a drawer containing a considerable number, but some of these were models or forgeries, and how many were genuine and how many false we were never told.

In September 1888, Mr. Brady again visited Cambridge to re-arrange his Foraminifera in the new cabinet which had been provided for them, and this year also Mr. Warburton, of Christ's College, added to the Invertebrate Collection a very complete series of British Spiders, which he had mounted and illustrated by sketches showing the principal peculiarities of each species.

In his annual report of this year, J. draws attention to the overcrowding of the Museum, aud the necessity for extension. In the same report Dr. Gadow records the death of Mrs. Strickland in August 1888. She had been a constant friend to the Museum, not only by her ever generous gifts, but by the incessant and pious care which she bestowed upon the efficient preservation and cataloguing of the Strickland Collection.

At Christmas 1889, Mr. Cooke resigned his position as Curator of the MacAndrew Collection, but he continued for a time to reside in Cambridge, and the University recognised the conscientious work he had done by conferring on him the title of Honorary Curator of the MacAndrew Collection. He was succeeded by Dr. David Sharp, who held office until 1909. The arrival of so eminent an entomologist in Cambridge gave a great impetus to the study of Insects, and a special room was now set apart for an Entomological Department, on the top floor, next to the room assigned to the Strickland Curator. Some years ago a second room was added to this by removing the partition wall. This enlarged room is, however, totally inadequate to house properly the extensive collections belonging to the University, or to afford accommodation for the students who wish to work there.

In 1889 the Stewart Collections of skulls and horns were for the first time exhibited in the Museum, and a valuable 
skeleton of the Jamaica Seal (Monachus tropicalis) presented by Dr. F. Du Cane Godman of Trinity College, was articulated and placed in the Museum. This species was hitherto "known only by a skin without skeleton, from Jamaica, preserved in the British Museum. In 1886 Don Ferrari Perez, Director of the Museum of Natural History, Mexico, chartered a small vessel and sailed from Campeché to a group of uninhabited islands in the Gulf of Mexico, called Los Triangelos. $\mathrm{He}$ stayed there for several days, and brought away with him a considerable number of specimens. Our skeleton was purchased of Mr. Ward, an American taxidermist settled in Mexico, who accompanied the expedition."

As a sign of the value of the material lying almost hidden in the Bird-room, I quote three sentences from the Strickland Curator's report for 1889 :-

"The Osteological Collection has been completely rearranged, and rendered more accessible to scientific visitors; the bones of each specimen, unless the skeleton be mounted and exhibited in the show-cases, are lodged in separate glasstopped boxes. The Collection now comprises the bones of at least 820 specimens, representing about 450 different species of birds, many of which are extremely rare, or even unique. Not only in actual value, but also in extent, this Collection compares favourably with those of most other museums, both at home and abroad, especially if we take into account the numerous skeletal preparations which are preserved in spirit, and form a particularly valuable feature of the Cambridge Museum."

In $1890 \mathrm{~J}$. was planning to transfer the whole of the Invertebrate Collection to the long gallery on the east side of the Museum, which had hitherto been used as a temporary laboratory for the classes in microscopical work in connection with the Department of Physiology. This Collection had been lately much increased by Mr. H. B. Brady, who had bequeathed to the Museum the remainder of his Collections. In this year also Colonel Feilden presented his Collection of Birds from 


\section{F. at the Museum of Zoology}

Barbados, whilst other specimens were continually arriving from many generous donors.

We have now come to the parting of the ways. J. was elected Registrary in 1891, and, although he could not at once give up his duties at the Museums owing to certain necessary alterations in the posts he held, he wrote his letter of resignation to the Vice-Chancellor without delay. In his report for 1890 he makes a farewell statement :-

"I have placed in the hands of the Vice-Chancellor my resignation of the office of Superintendent of the Museum, which I have held for exactly twenty-five years. In writing this, my last report, I wish, in the first place, to thank the Syndicate for the uniform kindness I have experienced at their hands, and for the liberality with which they have increased the Collection and provided adequate appliances for its display. It would, I think, be difficult, if not impossible, to find any Museum out of London so rich in specimens necessary for educational purposes, or in which the objects displayed are seen to such advantage. It would be absurd to affect indifference at leaving the post to which $I$ have been so long attached, and in holding which I have been supported by the cordial co-operation of all those with whom I have been brought in contact; but I am consoled by the belief that my resignation will promote the best interests of an institution which I have learnt to regard as almost my own. A younger Superintendent is now necessary, one who will bring to the discharge of his duties a more thorough knowledge of the present state of science, and of what is required to fulfil the exceptional conditions of a University Collection. I need hardly add that I shall be always ready to give help and information to my successor."

But a far longer period than was anticipated elapsed before the future constitution of the Registraryship could be arranged, and he held both the Superintendentship and the Secretaryship of the Museums and Lecture Rooms Syndicate 


\section{F.'s Resignation}

until the end of 1891, being assisted in the duties of the former post during the Easter and Michaelmas Terms and the Long Vacation by Mr. J. J. Lister of St. John's College. Mr. Lister devoted his time to a thorough revision of the exhibited portion of the Invertebrate Collection, adding many new specimens, and revising the MS. Catalogue.

The galleries mentioned above were now being gradually filled with what J. calls "a noble series of Invertebrata," and the cabinets of Insects which had hitherto been scattered through different parts of the building were now brought together in one room. It was whilst these changes, which had been unduly prolonged by a strike of workmen in Cambridge, were taking place, that $\mathrm{J}$. handed over his collections into the capable hands of Dr. S. F. Harmer of King's College.

In writing his first Annual Report to the Syndicate, the new Superintendent commences with the following words:-

"I can hardly begin my first Report to the Syndicate in any other way than by calling attention to the indebtedness of the University to Mr. J. W. Clark, the retiring Superintendent. It would be difficult to overestimate the extent of the services rendered to the Museum by Mr. Clark, whose labours in connection with the Department of Zoology during the past twenty-five years have placed the University in possession of a Museum which, in respect to its utility as a Teaching Museum at least, is probably second to none in the kingdom. I beg leave to record here my warm appreciation of the work of my predecessor. Mr. Clark has signalised his retirement by a most generous present to the Museum, ${ }^{1}$ in the form of a large case which is being placed on the south side of the gallery. This case is destined to receive a large part of the collection of Fishes which, with the Amphibia and Reptilia, are to be transferred to the gallery, in accordance with Mr. Clark's own plan. This alteration has been made

${ }^{1} \mathrm{He}$ also bequeathed his extensive Library of Voyages and Travels to the University to be placed under the charge of the Museums and Lecture Rooms Syndicate. 


\section{F. at the Museum of Zoology}

possible by the removal of the Invertebrate Collections to the gallery on the east side of the Museum, as explained in his Report."

In twenty-five years J. had built up a stately, well-furnished Museum of Zoology and Comparative Anatomy. Starting with the faunistic collections of the Philosophical Society, and the physiological and osteological specimens, very largely got together by the Professors of Anatomy, he had weeded out, developed, rearranged, and increased the Collections until when he left them they were indeed a noble instrument for instruction. There were of course helpers. Professor Newton's left hand never knew what his right hand was doing in the matter of adding specimens to the Museums. Under Dr. Gadow the Bird Room flourished mightily. Mr. Cooke, and later Dr. Sharp, with the sympathy but without the interference of the Superintendent, made the most of their departments. The net result was the Museum of 1891.

J. was not, of course, a skilled anatomist, or a very learned zoologist: he had not had the training; but he knew enough of both sciences to make a success of the Museum under his charge. Had he been more of a specialist, I do not think the Collections would have grown as fast as they did or in so many directions. He was very accurate in recording all new acquisitions, and he kept most careful catalogues. He was here as in other walks of life a good collector, and these characters encouraged many to place their treasured accumulations under his charge. He was clever at displaying a specimen so that it taught a lesson, and he was most anxious that we should go and see it when it was mounted. Once a year he held a little Exhibition of the specimens prepared during the previous twelve months, and this was both stimulating and instructive. It has now been given up-a loss, in my opinion, to the teacher and to the taught.

J. did not cater only for the undergraduate. His ambition, which Professor Newton fully shared, was that the Museum of Zoology and Comparative Anatomy should afford material 


\section{Professor and Superintendent}

for the expert, and many of the big Collections which came to Cambridge in J.'s time have done this. He sympathised with Mrs. Strickland's desire that the Collection ${ }^{1}$ she gave the University should aid the professed naturalist.

Two such strong-willed men as the Professor and the Superintendent did not-in the nature of things-always "hit it off." The Professor felt very strongly on a variety of subjects. To take one instance, he was convinced that the proper background for objects of Natural History, whether stuffed or in spirit, was a peculiar, rather washy bluish-slate colour. And there it is in many of our show-cases to-day. You didn't argue with the Professor; you couldn't. His attitude was, "I'm not arguing with you, I'm telling you," and in many cases he was telling you right. Still it saved friction and its consequence, heat, when J. established the preparation room on the top storey of Fawcett's Building, and the Professor first saw the new specimens all complete and set up. When so seen there was often acquiescence and in many cases approval.

During the quarter of a century that J. was Superintendent he relied largely on two servants : one, William Stubbings, who has been mentioned more than once; the other, Walter Robinson, upon whom a pension was conferred by the Syndicate the year J. left. Both were devoted to J., whose interest in their work never flagged, and when he had retired to the Registry he still kept this interest, and would drop in for a few minutes three or four times a week to see what skeleton Ernest Lane, the successor of Stubbings, was articulating, or what spirit specimen Arthur Corby, who had been recently appointed to mount the Invertebrates, was preparing, and generally to overlook what was going on. 


\section{APPENDIX II}

\section{J. AS SECRETARY TO THE MUSEUMS AND LECTURE ROOMS SYNDICATE}

When I first remember J. at the Museums in 1881 he had a double function. He was Superintendent of the Museum of Zoology and Comparative Anatomy, and he was Secretary to the Museums and Lecture Rooms Syndicate. 'The Museums and Lecture Rooms Syndicate had been instituted in 1866, and it was then a most august body. The following were its first members: Dr. James Cartmell, V.C., Master of Christ's College; Dr. H. W. Cookson, Master of Peterhouse; Dr. W. H. Bateson, Master of St. John's College; Professor (later Sir) George E. Paget; Professor (later Sir) George G. Stokes; Professor G. D. Liveing; Dr. S. G. Phear, afterwards Master of Emmanuel ; Mr. J. Power, afterwards Master of Pembroke; and Mr. J. W. Clark,

I have related elsewhere how I first met J., who in the early eighties was a kind of maid-of-all-work at the Museums, collecting fees for other people, helping to organise new departments, looking after his Museum, arranging the Philosophical Library, correcting what he used to call the "grosser errors" in the English of the Reports and other documents sent in by the several Professors or Curators, settling little disputes between Departments, and generally "keeping things going." The collection of lecture fees occasionally led to misunderstandings. I well remember a Trinity undergraduate, of a genial and chatty disposition, who having paid down his three guineas for Foster's Lectures, said as he was leaving the room, "I suppose you make a pretty good thing out of this, Sir!"

I was first put on the Museums and Lecture Rooms Syndicate 294 
in 1889 , and being comparatively new to University business I found the work interesting but at times quite bewildering. The meetings were often long and almost always lively. In the days when J. was Secretary, the plan of allowing each Department an annual sum-in fact a budget-had not been devised, and each bill of each Department- there were far fewer then ${ }^{1}$ was brought before the Syndicate and solemnly considered. We all tried to be intelligent, and to consider whether or not such an expenditure by the particular Department was justifiable; as a rule we thought it was, and then the ViceChancellor initialled the account. After a certain moment $J$. suddenly announced that we had exhausted the money at our disposal, and I supposed the uninitialled bills went back to those who had sent them in.

J. kept us all going by his running comments on men and things, especially on those whom he considered to be what he called "advanced." He used to affect a certain mild contempt for professors, a feeling which no one who had not been born of one and spent his childhood surrounded by others could possibly entertain. He enjoyed correcting their English and their orthography, and I think he enjoyed still more letting the Syndicate know that he had done so. On one occasion I well remember his blurting out, " Of course, Professor Z. behaved with his usual c-." Whether it was "carelessness" or "casualness" we shall never know, for the revered Vice-Chancellor, who was sleeping in the Chair, caught him on the initial C with a sonorous "Courtesr," and this without the intermission of a single nod.

As Secretary to the Syndicate J. had much to do with the management of two most useful funds: the Reserve Fund, which was established in 1883 to meet emergencies and to provide apparatus unexpectedly wanted; and the Microscope Fund, founded by the University in 1884 to provide certain Departments with simple and compound microscopes. He was also titular Librarian of the Philosophical Library, and a most

1 I mean Departments, not bills. 


\section{F. as Secretary to the Museums}

generous benefactor to that institution. The first time the Philosophical Library Committee published a list of gifts in the Annual Report of 1881, the number of publications, many of them in series, given by $J$. occupies three and a half pages of the Reporter.

From his lifelong connexion with the University J. had a remarkable knowledge and grasp of procedure. He knew exactly what you could do and what you could not do, and it cannot be concealed that in many small matters he not infrequently did what you could not do. He was an adept at addressing the Senate on paper; as he used to put it, he "understood their jargon," and he certainly drew up more and abler reports than anyone I remember. But then he took infinite pains. Time after time I have known him draft a report which seemed admirable, yet it did not satisfy him, and he would take it home and appear with it next morning recast and rewritten.

One conspicuous feature of J.'s life at the Museums, and indeed at home, was the devotion he inspired in the attendants and laboratory assistants. In the earlier days of the Museums and Lecture Rooms Syndicate many more servants were directly engaged and paid by that body than was the case later on. When the system of a budget was introduced, the appointment of all servants, except the porters, passed into the hands of the Heads of Departments. In consequence the great majority of the servants have had latterly comparatively little to do with the Syndicate, but in J.'s time it was otherwise. He knew and knew well a large number of them, but especially he knew the assistants at the Museum of Zoology and the porters. Of course he was petulant and at times irascible with them; but the attendants knew that in a short time the storm would blow over, and that beneath this "sound and fury" beat the heart of a real friend. In any time of sickness or trouble $\mathrm{J}$. visited them at their homes, carrying with him some flowers or soup or jelly or anything that their condition indicated. For many years after he had left the Museums, the senior servants, those of his time, turned first to him in time of trouble. 


\section{7. as Secretary}

When the Museums and Lecture Rooms Syndicate was started in 1866, J., as is mentioned above, was a Syndic. The same year he received his first University appointment, that of Superintendent of the Museum of Zoology and Comparative Anatomy, which he held for five-and-twenty years. Apparently, in the early days of the Syndicate, the existing Vice-Chancellor who presided at the meetings also acted as Secretary. In 1880 $J$. became Secretary at the request of the Syndicate, and in 1883 he was formally appointed by Grace of the Senate to the office, to which a small stipend was now attached.

J. of course knew, and knew well, the Old Physic Garden as a botanic garden. When he first used to work in a desultory fashion in his father's museum, the only buildings on the siteif we except the greenhouses-were the mean row of rooms erected for the Professors of Botany, and for the Jacksonian Professor in 1786, a couple of rooms added to the Jacksonian Professor's in 1833, and the dismal Octagon (1832-3) which housed his father's Department. When J. on becoming Registrary resigned the Secretaryship in 1891, Salvin's huge block, housing Zoology, Botany, Mineralogy, part of Physiology, the Philosophical Library, the Mathematical Professors, the Jacksonian Professor, Morphology and at one time Pathology, the Cavendish Laboratory, a considerable part of the Engineering Schools and of the Chemical Laboratory, and the new buildings for Human Anatomy and Physiology along Corn Exchange Street were all complete. Further, the site has been so increased from time to time that Dr. Walker's original garden was now bounded, east, west, and south, by public thoroughfares.

In all that these extensions represented $J$. had a full share. But when he resigned his official posts at the Museums, he in no sense resigned his interest in what provision the University could make for the furtherance of Science. Until the last few months of his life he showed an active interest in all the many buildings that were and are still being erected. As so much of his life was centred in the Museums, and as no one outside and very few inside-owing to the gradual growth of the buildings 


\section{7. as Secretary to the Museums}

and the concentration of each of us on our own work-appreciate what Cambridge has done for science in the last forty-six years, I have set forth as shortly as possible the history of the Museums in this Appendix. ${ }^{1}$

That this wonderful range of buildings, each specialised to a high degree to one particular object, should have arisen within forty-six years in an ancient University believed by threequarters of the world to be still solely the home of mediæval learning, is very largely due to the sympathetic attitude of those who represent what are called the older studies. At Cambridge the classic, the theologian, the historian, the literary man, the philosopher has ever helped-often most unselfishly_the Science School; and Natural Science owes to them a debt of gratitude which cannot be adequately put into words.

But the great outburst of building which began at the end of the last century, and which still continues, was only rendered possible by the funds collected by the Cambridge University Association, whose initiation the University owes to the genius of Mr. E. H. Parker, and whose steady success in raising funds is largely due to their Secretary, Mr. H. A. Roberts, and to J. himself.

\section{History of the Museums}

After many attempts to find a suitable site for a Botanic Garden, the Rev. Richard Walker, D.D., then Vice-Master of Trinity College, in 1760 " pitched upon and purchased the Manor house in Free School Lane (formerly part of an old monastery), ${ }^{2}$ with near five acres of garden about it, well walled round, quite open to the south," and conveyed it to the University. The area was, roughly speaking, rectangular, and the sides faced the quarters of the compass. It was bounded on the west side facing Free School Lane by a range of houses which at their

1 I deal here only with the site and the buildings, not with the Collections and the courses of lectures. As far as possible I have omitted names.

2 Augustinian. 


\section{Dr. Walker}

southern end made a "return" to the east. The Perse School was at this end of the range, while the Perse Almshouses constituted the "return" block and faced south. Some of the interesting rooms of the Old Perse School are still incorporated in the present Engineering School, and only in 1912 the Perse Headmaster's house was pulled down to make room for an extension of the Engineering Laboratory. ${ }^{1}$ Running north along Free School Lane there were other houses, until finally on the site of the latest extension of the Cavendish Laboratory, the Rayleigh wing, there was a single house fronting the lane "situated just behind the east end of St. Benett's Church and Corpus Christi College." This was known in the eighteenth century as "The Great House," and here Dr. Walker directed that the room on the ground floor should be appropriated for the reading of lectures on Botany, and an unfurnished room upstairs was to be set apart for the reception of books on Botany and for the housing of the Hortus siccus; and here on Monday, 18th April 1763, as the Cambridge Chronicle records, " at the Great House in Free Schole Lane, a course of lectures in Botany will be given by 'T. Martin, M.A., Prof.

"'The first course two guineas, the second course one guinea, ever after gratis. The lectures will begin exactly at 2 o'clock.

"Note.-The Professor intends to read gratis to those who subscribe ten guineas towards the support of the Botanic Garden."

On the northern side of our square the Botanic Garden was bounded on the west by the estate of Mr. Mortlock, and on the east by land now in the possession of the Corporation of Cambridge, on part of which the present Corn Exchange stands. ${ }^{2}$ Turning south again from the north-east corner there stood a series of warehouses and slaughter-houses, which were subse-

1 This house was occupied by recent Headmasters until the school was moved to its present site, but it was not the original house of the Perse Headmaster. See also p. 306.

2 The former Corn Exchange is the present "Arcade," now a bicycle shop and motor-car garage and printing works. 


\section{F. as Secretary to the Museums}

quently bought by the University, and which extended as far south as the angle of St. Andrew's Hill and Corn Exchange Street. The southern border of the Gardens was bounded by what are now known as Pembroke and Downing Streets, and along this frontier there were no houses. Diagonally across the southern part of this site from under the Perse Almshouses ran the King's Ditch, or watercourse, which still emerges from the old Botanic Garden site, a little to the south of the modern entrance to the Museums from Corn Exchange Street. The area which was left to the south of this ditch was then known as Tainter's Yard.

A range of greenhouses were the first buildings put up. They are shown in one of Ackerman's coloured prints with King's College Chapel towering in the background, and were erected along the northern confines of the area, very much in the position where the southern entrance of the present Examination Rooms now stands.

In 1784 the site of the "Great House" was sold to Mr. Mortlock, and it became necessary for the University to find a new lecture room for the Professor of Botany. The Jacksonian Professor, whose Chair had been established in the previous year, had as yet no lecture room, and from the nature of Richard Jackson's bequest it seemed appropriate that the Professor should deliver his lectures in or near the Botanic Garden. A Syndicate was therefore appointed, which ultimately recommended, and the Senate finally approved, the erection of a series of low buildings over the south-east corner of the site in the position now partially vacant and partially occupied by the Humphry Museum and the Medical Schools. The building put up in 1786 contained a lecture room 45 feet by 40 feet, and private rooms for the Professor of Botany at the end facing south, and for the Jacksonian Professor at the northern end.

At that time the entrance to the Botanic Garden from Free School Lane was a small Renaissance archway, taken down when the present Cavendish Laboratory was erected, and re- 


\section{The Old Physic Garden}

constructed within that building. 'This gateway is by far the most beautiful, one might say the only beautiful, thing we have at the Museums, but I have never known anyone look at it. It was situated about where the original Cavendish Laboratory now joins the Rayleigh wing. On the right of the archway stood the Curator's house. There was a second entrance to the Botanic Gardens on the south side, just to the east of the Perse Almshouses, but this was later replaced by a pair of handsome wrought-iron gates about the centre of the southern boundary. ${ }^{1}$ 'This iron gateway gave access to a broad gravel-path which led straight across the garden to the centre of the above-mentioned range of greenhouses. At one point this path crossed a narrow pond running east and west, thus cutting the garden into four squares. These squares were occupied with herbaceous and hardy plants, arranged after their kind in parallel beds running north and south.

As far back as 1696 efforts were being made to extend and improve the University Press, mainly at the instigation of the Duke of Somerset, who was elected Chancellor in 1688. A second or new printing house was then built to the north of the old printing house, which occupied part of the site of the present lodge and garden of the Master of St. Catharine's College. In 1696 this area was or had been the garden of Queens' College. This new printing house was used by the Press until 1716, when it was made over to the Professors of Anatomy and of Chemistry, because in the words of the Grace "it was of no use to the University for any other purpose." (Academioe alioquin infructuosum.) But the "modern building," as it was then called, was inconvenient and inadequate, there was no possibility of extension, and in 1786 the Professor of Chemistry was lecturing and using the new room of the Jacksonian Professor on the Botanic Garden site.

1 These gates, when the recent extension to the Chemical Laboratory was built, were taken down and re-erected as an entrance to the present Botanic Gardens in Trumpington Road. 


\section{F. as Secretary to the Museums}

The Professor of Anatomy, however, continued to lecture and demonstrate in Queens' Lane, but the dearth of lecture rooms was so great that his territory was invaded by both the Professor of Physics and the Professor of Modern History.

There was no provision made for Mineralogy when the Professorship was established in 1808, and Geology continued until 1840 to occupy, as Professor Sedgwick tells us, a room "small, damp, and ill-lighted, and utterly unfitted for a residence or a lecture room." This is the room now known to some members of the Senate as the Novel Room, situated at the northern end of the Arts Schools. The congestion however was becoming increasingly acute, and in 1831 a Syndicate was appointed to consider further provision for the various sciences. The following year they reported that "they consider sufficient accommodation may be secured to the Professor of Chemistry by a slight addition to the northern extremity of the building now standing on the Botanic Garden " (at present-1913-this site is vacant); and they also recommended that a triangular area between the private room of the Professor of Botany and the angle made by Downing Street and Corn Exchange Street should be set apart for the erection of buildings for the use of the Professor of Anatomy. Here the new buildings for Chemistry and Anatomy were put up in 1832-3, and with the rooms mentioned above the building sufficed for nearly forty years for the Professors of Botany, Chemistry, Physics, Anatomy, and of Applied Physics the then title of the Jacksonian Professorship. The building for Anatomy was the Octagon, so familiar to many of us. It included a museum, a small dissecting room, a lecture room, and one or two private rooms. The total cost seems to have been about $£ 3630$.

In the early thirties it was decided to move the Botanical Garden; the site of the old garden had proved to be too small, its soil had become exhausted, and it was surrounded by houses on three sides. A private Act of Parliament (1 Willian IV, cap. 5) which received the Royal Assent in 1831 enabled the 


\section{The $\mathcal{N}$ ew Botanic Garden 303}

University to obtain by exchange with the Master and Fellows of 'Trinity Hall the site of the existing Botanic Garden on the 'Trumpington Road, but no immediate change could be made, for certain leases did not expire until 1844. Even then the transference of the plants, etc., to the new site took six years, from 1846 to 1852 .

In 1830 proposals had been made to permit the trustees of Dr. Walker's garden to dispose of it, for the purpose of a market place or for any other purpose which might seem advisable. One suggestion was that it should be the site of the County Courts. Fortunately nothing could be done until the new ground came into the possession of the University; and by that time the near approach of the first examination for the Natural Sciences 'Tripos, which was held in 1851, made it evident not only that the Collections entrusted to the charge of the Professors were of ever-increasing importance, but that the number of students of Natural Science was likely largely to increase. A Syndicate was therefore appointed to prepare a scheme for legally acquiring the site from the trustees of Dr. Walker's garden, and in 1853 the Court of Chancery vested the ground in the Chancellor, Masters, and Scholars of the University on the consideration of a payment of $£ 3448,4 s$. $4 d$. to the trustees of the garden.

The same Syndicate then proceeded to consider how the site now at their disposal could best be utilised. They found that a new building should be erected for the accommodation of the Lucasian, the Plumian, the Lowndean, and the Jacksonian Professors, and for the Professors of Botany, Chemistry, and Mineralogy, including certain lecture rooms necessary for these seven Professors, of which the Syndicate assumed "that two at least may lecture during two terms, and the remaining five during one term"! Assuming this, they thought three lecture rooms would suffice for all the Professors. In their report the Syndicate go into very great detail as to the arrangement and allocation of the various rooms which they suggest the University should erect. 


\section{F. as Secretary to the Museums}

Schemes were prepared which would have cost over $£ 23,000$, to meet which the University had not more than $£ 5000$, and the whole plan was therefore delayed until 1860, when further funds became available.

In 1860 new plans, largely drawn up by Professor Willis, were put forward and met with a good deal of opposition, and there was much criticism, consideration, and reconsideration, all of which is minutely set forth in the Architectural History; but eventually in 1863 the block of buildings which has always been associated with the name of the architect, Mr. Salvin, was commenced. Salvin's building formed three sides of a square with an opening towards the north. The east side of the square was allotted to the Museum of Comparative Anatomy, and its erection was only rendered possible by J.'s father offering to lend the amount of its cost, £2364, at a nominal rate of interest. South of this was the lecture-room of Comparative Anatomy; and above that the room at first called the Museum of Zoology, but now known as the Birdroom. The building included the present Philosophical Library, while the floor immediately over it was allocated until recently to the Professors of Mathematics. West of the Philosophical Library building was the Botany lecture-room shared by the Jacksonian Professor, now temporarily assigned to the Department of Engineering; and running northwards on the western side of the quadrangle were rooms for Botany on the ground floor and Mineralogy on the first floor, the former now occupied by the Engineering Department. Still further west of the Botany Lecture Room were two four-square private rooms assigned to the Jacksonian Professor. Many years later these rooms were occupied by Mr. (now Sir) Francis Darwin and by Mr. Blackman as a laboratory for Physiological Botany. They are now part of the Engineering Laboratory.

This Salvin building, which cost some £20,000, was beginning to come into use just about the time when $J$. took up the duties of Superintendent of the Museum of Zoology.

J., as we have seen, was a member of the first Museums and 


\section{The Cavendish Laboratory 305}

Lecture Rooms Syndicate, and was many times re-elected. Later he became Secretary to the Syndicate, and in either capacity he took the greatest interest in all new buildings committed to their charge. He sat on all the Syndicates charged with their erection and equipment, was indefatigable in helping things on, and from his quick power of appreciating a difficulty or drafting a Report, and his equally great knowledge of Museum-fittings and of the ways of the University, was of the greatest service in the conduct of all business relating to new extensions.

In 1868, owing to alterations in the schedule of the Mathematical Tripos Examination, it became necessary for the University to provide further and better teaching in Heat, Electricity, and Magnetism : and, early in 1871, a Cavendish Professorship of Experimental Physics was established. On 8th March of the same year, James Clerk Maxwell was elected the first Professor, and was immediately added to the Syndicate then considering the erection of a Physical Laboratory. The seventh Duke of Devonshire-Chancellor from 1861 till 1892had most generously offered to bear the cost (about $£ 10,000$ ) of this building, which was afterwards known as the Cavendish Laboratory. J. served with his usual activity on this Syndicate together with Coutts Trotter of Trinity, who had hardly yet attained the height of the great personal power and influence which he ultimately exercised in the University. The site selected was behind the Free School Lane entrance to the Old Botanic Garden, just south of the "Great House," which in 1784 (see p. 300) had been sold to Mr. Mortlock, and which had to be repurchased before the most recent addition to the Cavendish Laboratory-the Rayleigh wing-could be added in 190\%. This last named wing, which cost some $£ \$ 000$, was materially helped by Lord Rayleigh, who gave to the Building Fund a large part (£5000) of his Nobel prize. ${ }^{1}$

Part of the earliest Cavendish Laboratory, which was begun in the late spring of 1872 and was in use by the

1 The rest of the prize Lord Rayleigh gave to the University Library. 


\section{F. as Secretary to the Museums}

Michaelmas 'Term of 1873, stood on the site of the Curator's house mentioned early in our story. The entrance from Free School Lane was now shifted a little way south, and on the southern side of this a porter's lodge was built. This lodge at first and for several years afterwards was however occupied by the attendant at the Cavendish Laboratory, the porter living in rooms which now form part of the ground floor of the laboratory of Mineralogy. The southern wing of the Cavendish Laboratory, which now covers the area between the present porter's lodge and the site of the Perse Headmaster's house ${ }^{1}$ now built over by Engineering - was put up at a cost of about $\mathfrak{L 4 0 0 0}$ in 1895 , and was largely paid for out of fees. By the pulling down of the Perse Headmaster's house in 1912, and its replacement by Engineering Laboratories, the Departments of Physics and Engineering are now brought into contact.

In 18\%2, a considerable addition was made to the Chemical Laboratory ${ }^{2}$ by the erection of a large room, well ventilated, and lit from above. This students' laboratory formed a first floor over the "private rooms" which had been put up in 1833. It must have been in this room that some eight years later I was examined in Practical Chemistry for an entrance scholarship. The examination was in charge of one whom I took at the time to be a Jesuit Father: but he can hardly have been one, for, when I next met him many years later, he was an Anglican Bishop. A cross-section of this laboratory coloured partly in Pompeian red can still (1913) be seen on the wall north of the gap between the Medical Schools and the Physiological Laboratory.

In this year (1872), J. and Michael Foster brought before the University the urgent need for proper provision for the teaching of Comparative Anatomy and Physiology. Hitherto, and for some years afterwards, all the practical work in those sciences had been carried on in the two rooms which, at that time separated by a central archway now indicated by the rounded windows, were in 1880 united to form the Philosophical

1 See p. 299.

${ }^{2}$ See p. 302. 


\section{Fawcett's Building}

Library. The passage between the northern and the southern courts was then through these windows.

There was a gallery around these lofty rooms which extended over the central archway, and thus, although the rooms were separate below, they communicated in the gallery. I have already mentioned that $J$. was the first founder of our Ethnological Collections. Before the two rooms which now form the Philosophical Library were made one, a stuffed bear, a collection of native bows-and-arrows, Dew-Smith and NewallMartin one day found themselves together in this gallery. DewSmith and Newall-Martin put the arrows into the bear, but, alarmed at the copious bleeding of sawdust that ensued, they hid the animal in a box. It disappeared. A few months later J. read an advertisement in the local paper of a stuffed bear to be sold at Barnwell. Of course he attended the sale, and he then found his own partially unstuffed specimen being put up to auction.

In 1873, the Museums and Lecture Rooms Syndicate reported in favour of the scheme submitted to them for further buildings for Physiology and Zoology, and their report was accepted by the Senate; but with the important exception that the University repurchased a site sold in 1786 between the eastern end of Salvin's building and Corn Exchange Street, nothing came of their report.

I have already stated ${ }^{1}$ that the classes which J.and Mr. Bridge started in 1871 had to be taught in J.'s private room, whilst he camped out at a table in the Museum. In 1876, the need of further accommodation became even more pressing, the teaching which Frank Balfour had established in Animal Morphology, at first carried on in one half of the present Philosophical Library, was now only made possible by the Professor of Zoology (Alfred Newton) giving up his private room for this object, and the classes in Physiology were increasingly overcrowded. The Museums and Lecture Rooms Syndicate accordingly introduced a revised report, which was again agreed to by the Senate, and this time, i.e. in the summer of 1876,

$$
{ }^{1} \text { p. } 271 .
$$




\section{F. as Secretary to the Museums}

building was begun. Mr. Fawcett was the architect, and the tender which was accepted amounted to $£ 8500$. But further delays occurred; the Syndicate had been recommended to use concrete instead of wood for the roofs and floors of their new venture, and in February 1878 a huge slab of this material which was being placed in the north-east portion of the building fell, crashing through floor after floor to the ground. This accident induced the Syndicate to seek further expert advice, and ultimately to replace the concrete by wood. Another cause of delay was a dispute about ancient lights with the owner of a house in Corn Exchange Street; and altogether it was not surprising that the year 1879 was reached before the new building was fully occupied.

This building, which extended from Corn Exchange Street to the eastern walls of the Zoological Lecture Room and the present Birdroom, was in three stories with good basements. The central floor was entirely given over to Physiology, and the Physiologists later encroached a little on both the other floors. On the ground floor were four workrooms, and private rooms for the Jacksonian Professor (now store-rooms), for the Professor of Zoology, for the Professor of Anatomy, afterwards Professor of Surgery, and for J. J.'s room is occupied now, as it was then, by the Superintendent of the Museum of Zoology. The top floor had nine rooms: that on the east was Balfour's laboratory, with a private room next to it; the Professor of Anatomy had a class room for microscopy to the north. The other rooms on the south were used by J. as preparation rooms, by the Demonstrator, and by the Strickland Curator.

Whilst all this was going on along the eastern frontier of the Old Botanic Garden site, something was also taking place on the western. James Stuart had in 1875 been elected to the newly-established Professorship of Mechanism, and it was not long before he was drawing the attention of the Museums and Lecture Rooms Syndicate to the want of a workshop and drawing-office in which he could instruct his 


\section{The Pbilosophical Library 309}

pupils. In the summer of 1878 a workshop of the most modest appearance was put up in the garden, west of the Botanical Museum, followed by a drawing-office in 1881, by further workshops in 1882, and by a foundry in 1884. Professor Stuart stocked these with instruments and machinery largely at his own cost, though they were subsequently bought by the University.

During the summer of 1879 a new room was built over the then entirely inadequate Human Anatomy dissecting room and an adjacent private room. The former was opened as a dissecting room in the October of that year.

'The Philosophical Library, as we have seen, ${ }^{1}$ was constructed in $\mathbf{1 8 8 0}$ by the removal of the central archway to the eastern end, and thus the two rooms on the ground floor were thrown into one. By an arrangement made between the Philosophical Society and the University the library of the society was moved into this room during the Long Vacation of 1881 and made accessible to members of the University. As long ago as 1865 leave had been given to the Philosophical Society to use the room between the Mathematical Professors' room and what became the first Balfour Library, and here their Council met, and here at first their books had been stored until they were removed in 1881. This removal, calling attention to the library, resulted in its increase. Numerous donations of great value were now received. For many years the present Philosophical Library room was used both as a library and as an examination-room until the ever-accumulating books crowded out the examinations.

Before proceeding further with the really amazing history of the Science buildings so long associated with J. it will be well briefly to record the various purchases the University made to round off the Old Botanic Garden site. On the ground where the original Cavendish Laboratory now stands were some offices bought in 1856, and in front of them, next Free School Lane, two dwelling-houses which originally had

1 pp. $306,307$. 


\section{Iо 7. as Secretary to the Museums}

formed the inn known as "The Three Cups." These houses the University acquired in 1862 and 1871 respectively. South of these, facing the back of Corpus Christi College, were three more dwelling-houses which were bought in 1871, 1874, and 1875 respectively. One or two of these continued to be occupied by tenants for a year or two; the rest were used as store-rooms for the Department of Mechanism. Turning to the eastern boundary, the area between Fawcett's building and the southern end of the Corn Exchange was bought by the University as follows: (1) certain warehouses leased by the town authorities to Messrs. Headly, with the ground they stood on, forming nearly half the total area, in 1881; (2) certain tenements belonging to St. Edwards' Parish, just north of Fawcett's building, in 1883; and (3) the broad strip intervening between (1) and (2), which now forms part of the site of the large Physiological and Anatomical Lecture Room, from the Corporation of Cambridge, in 1884. But this same year the University made a still more important addition to the Old Botanic site. The Senate agreed, in the month of June, to buy the Perse Almshouses which stood facing Pembroke College Lodge in the south-west corner of our area. Including the cost of removing the Almshouses to Newnham, where they now stand, the sum paid was £2675. In 1888, the site, with a frontage of 218 feet on Free School Lane, of the boys' Perse School, then about to be removed to Hills Road, was, though some " non-placet" votes were given,

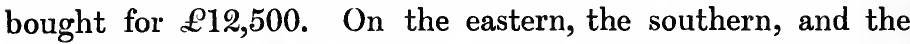
western sides the Museum's site was now bounded by public thoroughfares. The Perse School site was the last purchase made whilst J. was secretary to the Syndicate, but we may as well complete the catalogue of acquisitions. In 1896 the University gave $£ 12,000$ for the garden-ground and adjoining premises at the back of Messrs. Barclay's (late Mortlock's) Bank, extending from Parson's Court to Free School Lane, and comprising an area of 28,924 square feet. On this area the Rayleigh wing of the Cavendish Laboratory, the Examination Rooms, and the new Lecture Rooms now stand. A house adjoining this 


\section{Mortlock and Downing Sites 3 I I}

part of the Mortlock garden was purchased by the University in 1901 for $£ 500$. This, I think, completes the list of purchases on the Old Botanic Garden site.

A new era of expansion for both the arts and the sciences was made possible, however, by the purchase of the Downing site about this date. The Senate must have been in an expansive and buoyant mood in 1896, for not only was it willing to spend $£ 12,000$ on the Mortlock garden, but it put down another $£ 15,000$ and purchased two acres of the northern end of the grounds of Downing College. In the following year, it widened its Downing site by the further purchase of an additional strip on the southern boundary forty feet wide, which was paid for at the rate of $£ 5000$ an acre. In 1902 the Senate agreed to purchase a still further six and a quarter acres at a somewhat lower figure. The details and conditions of these several purchases are minutely set forth by $J$. in the Endowments of the University of Cambridge, 1904.

Let us now return to the Science buildings under the charge of the Museums and Lecture Rooms Syndicate in the year 1882. The great success which had attended the teaching of Michael Foster and Frank Balfour had attracted a large number of pupils, far too large in fact even for the new quarters to accommodate. The Museums and Lecture Rooms Syndicate was appealed to, and after careful inquiry they recommended the addition of a third story to the central Salvin building. The Senate concurred, and accordingly, above the Mathematical Professors' rooms, which in turn were above the Philosophical Library, a long well-lit laboratory was built in 1882. At the eastern end were two private rooms, one of them long occupied by Mr. Adam Sedgwick. Access was given by means of the gallery of the Bird-room as well as by the western staircase. Unhappily, Professor Balfour (just appointed to his Chair) never saw these rooms; the tragic accident which befell him in the Alps that summer cut off prematurely the life of one of the greatest biologists of all ages. 


\section{I 7 . as Secretary to the Museums}

The rearrangement of the M.B. Examinations and the vigour with which Mr. Adam Sedgwick carried on Balfour's teaching brought about a further increase in the number of students. The most urgent need was a room in which to conduct the practical work of the Elementary Biology course for the remodelled First M.B. Examination, and this was provided in 1884 by bodily lifting the roof of the Mineralogical Museum and building up walls underneath it. "So skilfully was this singular operation carried out by Professor Stuart and $\mathrm{Mr}$. Lyon, Superintendent of the Department of Mechanism, that ' not a single slate in the roof was broken or strained, and the whole work of lifting the roof and building the exterior walls was completed in seventeen working days, the weight lifted being 50 tons, and the total length of the roof, 110 feet." The elevation of this roof enabled a spacious and well-lit Laboratory to be arranged with an office at the southern end, with a Laboratory at the northern end for senior students, and with a private room for a demonstrator. During the same summer a second floor was added to the south-western annexe of the Herbarium for the teaching of Physiological Botany, and also a lean-to gallery running along the eastern side of the Herbarium for classes in Practical Botany. Both subjects were then being actively taught by Mr. S. H. Vines, of Christ's College, now Professor of Botany at Oxford. The lean-to Laboratory was removed when the Engineering Department built the modern Drawing Office in 1903. Some years previously Botany had gained three rooms, part of the old Porter's Lodge. In 1880, the attendant at the Cavendish laboratory, who lived in the present Porter's Lodge, died, and the porter of the then "Museums," who had lived in a small house, now the Chemical laboratory of the Department of Mineralogy, moved to the present Porter's Lodge. His house was at first added to the Department of Botany and, when this Department moved across Downing Street, to Mineralogy.

For many years Professor Liveing had been pointing out 


\section{New Chemical Laboratory 3 I3}

the urgent need of a new Chemical Laboratory, and with the acquisition of the Perse Almshouses, a convenient site was at hand. After much discussion and much inspection of the more recently erected chemical laboratories at home and abroad, plans drawn up by Mr. J. J. Stevenson were accepted by the Senate, and in December 1885, as soon as the ground could be cleared, the building was begun. Facing the end of Free School Lane and a good length of Pembroke Street, it was built in a more ornate style than the majority of the "Museums." The at first anæmic and then dingy Cambridge white bricks were discarded for a stone façade facing the street, while red brick walls looked on the southern court. This building took a long time to complete, owing to the complexity of the fittings. Its progress can be traced in successive annual reports of the Professor of Chemistry and the Jacksonian Professor. At last, in May 1889, they write, "We are now in possession of the whole building, and we are glad to be able to state that it fully answers our expectations."

Before passing on to other departments I may, perhaps, shortly describe the extensions of the Chemical laboratory. Towards the end of the year 1899 an attic over the large Elementary Laboratory was adapted for students' work. Under Mr. J. J. Stevenson's advice, dormer windows were inserted in the roof, the staircase was prolonged, the fume-closets were connected with the existing flues, and benches for thirty-two students were fitted up. The work was completed by the summer of 1900, and gave great satisfaction to the Professor. But a few years later a further extension became necessary. In his annual report for 1905, Professor Liveing mentioned that "every available bench in the general laboratories has been occupied," and "that Caius College has decided shortly to close its Chemical Laboratory." Sidney College had at about the same time arrived at a similar decision. Hence it seemed obvious that by October 1907 a large accession of students would present themselves at the University Laboratory. The matter was urgent, and after some discussion as to the form the 


\section{I 4 . as Secretary to the Museums}

building should take, and its exact position, it was decided to fill up the gap between the existing Chemical Laboratory and the site of the present new Medical Schools, leaving an entrance archway with a Porter's Lodge at its eastern end. The building was designed by Mr. Redfern, partner of the late Mr. Stevenson. It was begun in 1907 , and was in partial use by the autumn of 1908 .

When Chemistry first moved into its new quarters in 1889 the rooms on the eastern side of the southern court which were now set free had been put at the disposal of Professor Roy, who, since his appointment in 1884, had been struggling to teach Practical Pathology in two small rooms opposite to the private room of the Strickland Curator, on the third floor of Fawcett's building.

We must now retrace our steps and return to the Octagon, or the second home of Human Anatomy in Cambridge, which lay on the south-east corner of the site. It seems surprising, as I have said in the previous chapter, ${ }^{1}$ that not until 1871 did our Medical School obtain recognition by the Royal College of Surgeons. From that date only could a student complete the required courses of Anatomy and Physiology at Cambridge. In his report for 1884, Professor Macalister writes, "No department of University work is so badly housed as the Department of Anatomy." This wail was not without its effect, and immediate relief was granted by the erection of a spacious corrugated-iron shed of the usual hideous appearance, which, placed on the west of the Octagon, occupied a site partly covered by the existing Medical School, but projecting a little into the southern Court. This shed was used for a few years as a dissecting-room, and when Human Anatomy moved into its new quarters near the Corn Exchange, it was for a time utilised as a laboratory for teaching practical Physics to the candidates for the First M.B. Examination.

The alleviation afforded to the Department of Human Anatomy by the corrugated-iron shed was indeed but temporary; for the condition of the old Anatomical buildings was 


\section{Human Anatomy and Pbysiology 3 I 5}

such that burning or pulling them down was the only remedy. Already in 1880 Professor Humphry had drawn attention to the invasion of dry-rot, and the fabric was in a state of advanced decay--the panelling, skirting-boards, and floors were but whited sepulchres. Beneath all was dry-rot and decay, and I, who have seen much dry-rot, have never seen such luxuriant growths of Merulius lacrymans as the detachment of these boards revealed. In spite of this state of things the Octagon was used for another fifteen years, though not by Human Anatomy.

Physiology, too, was again clamouring for more space, in spite of the fact that the annexe mentioned above, with a gallery well adapted for histological work, had been erected, in the winter of 1886-7, along the eastern side of the Museum of Zoology as an extension to the Physiological Department. In his report for the year 1886, Michael Foster, whilst welcoming this addition, points out "that the banishment of a portion of my class to a room so disconnected with the rest of the Laboratory is a very serious evil." Next year, he was pleading the cause of Psycho-Physics; whilst Professor Macalister was saying, "The want of a suitable lecture-room is still grievously felt, and the accommodation for practical work is taxed to its fullest extent." In 1889, then, the Museums and Lecture Rooms Syndicate turned their attention to the provision of a large increase to the existing Physiological Laboratory, to the building of an entirely new Anatomical School, and to the erection of a large lecture-room, between the two and common to both. Unfortunately the plans prepared by Mr. Fawcett proved more costly than either the Financial Board or the Syndicate had anticipated, and the whole scheme was in danger of being indefinitely delayed, when, in November, Professor Henry Sidgwick offered $£ 1000$ at once, and promised $£ 500$ more within two years, "provided that the Financial Board, in consideration of this offer, feel themselves justified in reporting in favour of commencing these buildings without delay." 1

1 Reporter, 1889-90, p. 170. 


\section{I6 $\mathcal{F}$. as Secretary to the Museums}

So generous an offer touched even the hearts of the Financial Board; they withdrew their opposition, and helped to pass Graces of thanks to Professor Sidgwick, whose generous gift had removed a real obstacle to the progress of the building. The site which had been selected ran along Corn Exchange Street from the northern end of Fawcett's second building as far as the present Corn Exchange, where there was a short return towards the west. The new rooms for Physiology were naturally placed at the southern end, contiguous to the older part of the Laboratory. Human Anatomy was placed next the Corn Exchange, and a large lecture-room was built between them. This room, capable of seating 280 students, has, like other lecture-rooms designed by Mr. Fawcett, excellent acoustic properties. Before beginning the building, certain tenements, which, if I recollect, were on the south end of the site, had to be cleared away, but no time was lost, and the buildings were ready for occupation early in 1891 .

This was the last building erected whilst J. was Secretary to the Museums and Lecture Rooms Syndicate. In the spring of 1891 he had been elected Registrary, and at once set about making arrangements for resigning the posts of Secretary to the Syndicate and of Superintendent of the Museum of Zoology. But adjustments had to be made not only in the duties of these posts, but also at the Registry ; and the resignations were deferred, and only became effective at the end of the year. The letter to the Vice-Chancellor in which he offered to resign the secretaryship is dated 14th May 1891; and the Syndicate in their annual report for 1890, signed on 26th May 1891, express fully and feelingly their sense of J.'s services to the Museum. They say :-

"The Syndicate learn with regret that their Secretary, the present Superintendent of the Museum of Comparative Anatomy and Zoology, has sent in his resignation to the Vice-Chancellor. They feel they cannot let this opportunity pass without expressing to the University their sense of the very great value 


\section{F.'s Resignation}

they attach to the services Mr. Clark has rendered. He became Superintendent of the Museum of Zoology in 1866 and Secretary of the Syndicate in 1880. For some years he discharged without salary the duties of this office, to which in 1883 he was formally appointed by the Senate. During the period he has held office the buildings under charge of the Syndicate have grown enormously, and in everything connected with the growth Mr. Clark has borne a most prominent share. His knowledge of the past history of University matters, his practical acquaintance with architecture and buildings, and his skill in placing clearly before the Senate the various questions to which the Syndicate have had from time to time to call attention, have been invaluable. The Syndicate feel that no small share of the success which has attended the Natural Science School in the University is due to Mr. Clark. He has always been most ready to place his services at the disposal of everyone connected with the Museums, and his resignation will leave a blank it will be hard to fill."

I might now bring my abbreviated history of the Museums to a close, but here there is no natural break. Although J. ceased to be Secretary to the Syndicate, he was constantly a member of it; and, whether a member or not, he took the keenest and most practical interest in all new science buildings, and the Syndicate never failed to secure his knowledgeable, if trenchant, criticisms on plans submitted to them. However, at the end of the year 1912, in which I am now writing, there is a break - whether natural or not, at least final-for at midnight on the 31st December 1912 the Museums and Lecture Rooms Syndicate was dissolved and ceased to be; hence it may be as well to continue our catalogue of new buildings until that date. But a last and even more compelling motive for taking this course is that I enjoy writing this desultory record, and so I shall go on doing it as long as I can.

Professor Ewing had been elected to the Chair of Mechanism and Applied Mechanics in November 1890, and in his 


\section{I 8 . as Secretary to the Museums}

first annual report he welcomes the proposal of the Syndicate, appointed to deal with the Perse School site, to allot the main part of the existing buildings to his Department. Until new buildings could be arranged for, the work was carried on in the old school-rooms and hall. I should here remind the reader that when the site and existing buildings were purchased, ${ }^{1}$ the headmaster's house was assigned to Botany, and afforded "excellent accommodation for Practical Physiology and Morphology." When Botany was removed to the Downing site in 1903, this house was handed over to the Department of Mechanism, and was used for some years as a chemical laboratory, until in the summer of 1912 it was pulled down, and, in its place, an extension of the Laboratory was erected to house the electrical part of its work. In 1903 three rooms of this house were also placed at the disposal of the Special Boards of Classics and of Mediæval and Modern Languages; but they proved not very suitable for this purpose and were soon given up.

To return to the main Engineering Laboratory. When Professor Stuart resigned in 1890 the number of students was large, and this number soon increased, stimulated by the arrival of Professor Ewing and the proposed establishment of an Honours Examination in Engineering. 'The first Tripos Examination was held in 1894. More and better accommodation was required; and in June 1893 the central block of the existing Engineering School, and in the following November the southern wing, were begun, and both were formally opened in May 1894. It may be pointed out that all the buildings of Engineering have been not only put up, but furnished at very little direct cost to the University. With the exception of $£ 1000$ contributed from the University Chest, the whole cost of building and equipping the central


subscription.

A few years later, in October 1898, the Vice-Chancellor published the following letter:-

$$
{ }^{1} \text { In } 1760 . \text { See p. } 298 .
$$


13 th October 1898.

"Dear Mr. Vice-Chancellor,-I desire, jointly with my son and daughter, Bertram and Ellen Hopkinson, to give $\$ 5000$ towards an extension of the Engineering Laboratory in the University of Cambridge, to be erected to the memory of my husband John Hopkinson; and of our son John Gustave Hopkinson, who was entered as a student in the Engineering School for this October, and would have followed his father's profession.

"It seems to us a peculiarly fitting memorial, as Dr. Hopkinson, from the first, was warmly interested in the new school, and quite lately expressed a strong desire that an addition should be made to meet the rapidly increasing demand for accommodation, and had stated his intention of taking immediate steps to further this extension. It was also a special satisfaction to him that our son Jack was to benefit by the opportunities afforded in the engineering laboratory, under Professor Ewing, whose fine teaching and masterly scientific work he felt ought to have the fullest possible scope. We hope that our gift, which we should like to see applied as soon as may be, will make this wider field possible.-Trusting it will meet with your approval, I am, dear sir, yours faithfully,

"Evelyn Hopkinson."

This munificent offer was gratefully accepted, and the Public Orator prepared a letter of thanks which was duly sealed. Building was begun at once, and the John Hopkinson Memorial Wing was formally opened in February 1900, one of the finest rooms in it being decorated by a striking likeness of him to whom the building is dedicated. The very inadequate workshops put up by Professor Stuart in the eighties are being gradually replaced. But the greatest extension took place when Botany moved across Downing Street in 1903. Except for a room or two at the northern end which fell to Mineralogy, and a small annexe on the second floor, projecting west from the southern end, which was given to Morphology, the whole of the space formerly occupied by Botany was allocated to Engineering. The large Botanical Lecture-room was tem- 


\section{F. as Secretary to the Museums}

porarily assigned to the same department. Engineering being now in the possession of the old Herbarium, it became possible (as we have already seen ${ }^{1}$ ), by removing the lean-to laboratory which ran along its eastern wall, to construct a spacious onestoried Drawing Office, which projected over nearly one quarter of the area of the northern court. This was first used in October 1903, and the opportunity was taken to add a small but convenient and well-lit lecture and class room for the use of the mineralogists on the northern side of the Drawing Office.

We must now go a long way back and try to unravel the history of the Geological Museum, a very tangled tale. In olden times natural curiosities of various kinds often found their way to the University Library, and hence one is not surprised to learn that shortly after Dr. John Woodward's death, in 1728, his "Fossils, a vast quantities of Ores, Minerals, and Shells, with other curiosities well worth viewing," were deposited in the Library, and in 1735 the present Novel Room, at the northern end of the Arts Schools, was being fitted up for their storage and display. Almost a century later, in 1818, we find the Syndics of the Woodwardian Museum of Geology representing "that it was desirable that a larger room should be built, with a contiguous room for the accommodation of the lecturer." Now geologists deal in geological time, and this may be the explanation of the fact that in anything to do with the Woodwardian Museum the progress has always been of the slowest. To those who traffic in æons, the delay of fifteen or even twenty-five years must seem momentary. This may also partially explain the extraordinary number of Syndicates which have met about the Museum; they obviously exchanged views, and finally issued reports, but little or nothing came of their deliberations.

There was (1) a Special Syndicate, in 1821, to consider the building of a Museum for the Collection; (2) another, appointed in 1824 , published a "Statement" in 1828 , now known to have 


\section{Geological Museum}

been drawn up by Dr. Whewell; (3) another Syndicate was appointed on 6th May 1829 to consider how the old court of King's could be "converted to Academic use," and incidentally to provide for the Woodwardian Museum. This lastnamed Syndicate was the cause of a war in the University which lasted for eight years. Members of the Senate early in the nineteenth century held very strong views as to the allocation of the site in question, and as to the numerous plans put before them by the several architects then employed. And in those days, when members of the Senate held strong views, they expressed them strongly. The 1829 Syndicate (3) indeed lost no time, and reported on 2nd July of that year, and the report being unopposed it was adopted on 6th July. Amongst the instructions which it provided for the architects were: "It is required to provide... for Museums of Geology, Mineralogy, Zoology, and Botany, for three or four lecture-rooms, for workshops and unpacking rooms connected with the several museums," and for a variety of other needs not immediately connected with our purpose.

The four firms of competing architects sent down their plans by 1st November 1829, and after consideration in what must be one of the shortest reports on record (it is barely four lines in length), the Syndicate recommended the acceptance of Mr. Cockerell's design, No. 1. Thus far the scheme had made rapid progress, but when the design was "inspected" by the members of the Senate there was instant opposition. Their excitement was so great that a Grace confirming the report, and another applying to $\mathrm{Mr}$. Cockerell for an amended design, were for some inexplicable reason withdrawn, and a fourth (4) Syndicate was appointed to inquire and report on the state of the University finances. Although this Syndicate reported in May 1830, its report has completely disappeared, and of it no record remains. In the meantime Mr. Cockerell had prepared a second design, and on May 31, 1830, a fifth (5) Syndicate was appointed to consider, amongst other things, "the construction of Museums and 


\section{F. as Secretary to the Museums}

Lecture-rooms." This Syndicate issued a revised form of instruction to the architects, and this time the Museum of Zoology was left out.

Again the architects submitted "designs," and again on their being submitted to the Senate the most violent divergence of opinion broke out. Prominent in the discussion were both Peacock and Whewell. Towards the end of the year (1830) the fifth Syndicate recommended the Senate to accept the plans of Messrs. Rickman and Hutchinson, but for some reason this recommendation never reached the Senate, and the whole thing now fell into abeyance for nearly four years.

On the 14th March 1834 a sixth (6) Syndicate was appointed to confer with the architects, but apparently all they did was to offer them a fee for the trouble they had been put to. The next step was taken exactly one year later, when another (7) Syndicate-this time a very large one-was appointed to collect money for the proposed buildings. By the beginning of the academic year they had been so far successful as to place over $\mathfrak{2 0}^{2}, 000$ at the disposal of the University. Thus encouraged, the Senate on 18th November 1835 appointed yet another Syndicate (8), and so cheered were these Syndics that within one week of their appointment they had issued no less than three reports! It goes without saying that their first report (A) recommended the Senate to appoint still another Syndicate, which was to find out if the University had any funds of its own which might be available for the proposed increase to the Library, and the provision of Museums, etc. I do not think this last Syndicate was ever constituted. If it was, we might call it $(8 a)$.

'Three of the architects now sent in fresh designs, and at last on 11th May 1836 a large majority of the Senate accepted Mr. Cockerell's plans. On the same day another (9) Syndicate was appointed to inquire if these plans were in conformity with the instructions of the Senate, and in seven days they reported that they were, and that the portion of the building which was to be put in hand at once could be built for $£ 25,000$, 


\section{Geological Museum}

but that Mr. Cockerell "declined to pledge himself to this precise sum." A Grace confirming their Report was prepared, but the caution of Mr. Cockerell alarmed Dr. Webb, the Master of Clare Hall, who brought the whole thing again to a standstill by vetoing the Grace in the Caput.

A former Syndicate-I think No. 8, that of 18th November 1835-was now revived, and conferred again with Mr. Cockerell, and after some time they reported that certain parts of the building could be put up for $£ 25,000$. This time the Report was carried by twenty-two votes to five, and (7th December 1836) a (10) building Syndicate was appointed with powers to confer with Mr. Cockerell.

Architects do not always command one's sympathy, but my heart goes out to Mr. Cockerell.

The last-mentioned Syndicate (10), after some months, reported in March 1837 in favour of erecting the northern wing of the building to begin with, and this was actually begun in June of the same year, though the foundation stone was not laid until September nor the contract sealed till October.

Once begun, the building went forward smoothly. By the beginning of 1840 the architect certified that the substantial work of the structure was satisfactorily completed. The task of putting in the fittings was spread over nearly two years, and by the end of 1842 the rooms were ready for occupation. The various suggestions for University buildings which had occupied the earlier of these multitudinous Syndicates had reduced themselves to two-a large extension of the Library, and a Museum with a Lecture-Room for Geology and Mineralogy. The building as finished, in what for a better term I can only call the Cyclopean style, was divided into two nearly equal halves: above, a lofty library with alcoves and side galleries; below, the Woodwardian Museum, and rooms for Mineralogy with a spacious basement. This basement was partly but imperfectly lit by an enormous hole in the floor of the main Museum, through which one used to peer down at the skeletons of prehistoric vertebrates. Its cost was put 


\section{F. as Secretary to the Museums}

at about $£ 35,000$, and the difference between this sum and that collected-about $£ 23,500$ - was met out of the Library Reserve; but the cost of the fittings of the Geological part was paid for out of the Woodwardian Fund.

Twenty-nine years later, in what, as he only too clearly foresaw, was his last Annual Report, Professor Adam Sedgwick issued the following pathetic appeal; and, as it also contains a short history of the Collections, and shows how the Woodwardian Collection had been surpassed by the Sedgwickian, I cannot refrain from reprinting it:-

\section{Woodwardian Museum}

Statement of the Woodwardian Professor: and List of Subscribers to the Purchase Fund of the Leckenby

\section{Collection}

To the Noblemen and Gentlemen of the University of Cambridge, and especially to the Heads of Colleges, the Members of the Council, and the Members of the Senate, the following Statement is addressed by their very aged and infirm, but very affectionate and grateful Servant,

\section{Statement}

Adam Sedgwick.

The old nucleus of the present Geological Museum is of considerable antiquity. It came to the University of Cambridge, partly by the bequest of Dr. Woodward, and partly by purchase from his Executors, about the year 1727, but it was in a good measure formed during the latter part of the preceding century. This collection is still entire (with the exception of a few specimens that have undergone spontaneous decomposition), and is preserved with its copious Catalogues in one of the closets of the present Museum, as an object both of scientific and historical interest.

The present Geological Collection was begun by the writer of this Statement in the year 1818; and by his personal labour continued for many succeeding years, by the kind and generous assistance and munificence of Academic friends, and by various 


\section{Professor Sedgrick's Appeal}

purchases made by the University, it has become what it isone of the noblest collections, so far as regards British Geology, that exist in England. I do not compare it with the gigantic and unrivalled collections in the British Museum; but as a collection for study and for practical use, I think it inferior to no collection existing in this island; and of late years it has become more and more frequented by persons devoted to the study of the Natural Sciences. But Geology is a very progressive science, and there are gaps and defects in our collection which must be supplied if it is to hold its present high rank among the Museums of England.

A grand occasion, such as may never again be met with, now presents itself. Mr. Leckenby, of Scarborough, offers to transfer his entire and beautifully arranged collection to the Woodwardian Museum for the sum of $£ 800$. Many scientific persons (and among them I am happy to name Professor Morris) have declared this collection to be of its kind unrivalled. It has been formed during a good many past years by Mr. Leckenby, at a cost many times greater than the sum above mentioned; and our Assistant Curator, Mr. Henry Keeping, an excellent judge on the question, regards it of inestimable value as an addition to the Cambridge Museum, and thinks it is offered on terms much below its value. It is most strong where the present Cambridge collection is most weak, that is, in the Mesozoic or Oolitic series of this island.

All the specimens, amounting to more than 4000, are of the choicest character. For many Mr. Leckenby paid 20s. each, for some $£ 5$ each; and indeed on his favourite object he appears to have spared no cost.

After having given my annual lectures for fifty-three years without a single break in the series, I have been compelled to entreat the University to appoint a deputy to give my annual course; and Professor Morris, a name well known and honoured by all the geologists of Europe, is now under University appointment filling my place in the Lecture-Room.

With thankfulness to God for the past, I know well that 


\section{F. as Secretary to the Museums}

I must soon be called away from all earthly duties; but it. would cast a gleam of light on my declining days, and fill my heart with good hope for the future of Cambridge, could I see the noble and in many respects the imcomparable collection of Mr. Leckenby placed in our Museum.

I write this statement with the strongest feelings of love and reverence for the whole Academic body, and for that College which has been my home, now for the long period of sixty-seven years; and I cannot but earnestly and confidently hope, that what I have now recommended to the University may become an accomplished fact, honourable to the present history of the University, and a pledge of permanent security to its good foundations that are laid in the interests of knowledge and of God's truth.

\section{Trinity College,}

23rd November 1871.

It is pleasing to think that, owing to the exertions of Dr. Cookson and of J., the money to purchase the Leckenby Collection was soon got together, very largely by contributions from the several Colleges. This happy result gave profound pleasure to the Professor, who writes: "This information raised in my heart an emotion of grateful joy such as I have not felt since the brightest and happiest days of my youthful life."

Soon after Adam Sedgwick's death in 1873, a meeting of his friends and admirers was held in the Senate House to arrange for an adequate memorial to the great geologist, and so deep was the regard and widespread the affection he had invoked that in a comparatively short time no less a sum than $£ 11,153$ was subscribed to perpetuate his memory.

His successor, Professor Hughes (1873), at an early period found difficulty in arranging the new Geological acquisitions in their proper order. The cases were already filled, and as time went on he emphasizes more and more the want of space and light, and the overcrowding of the teaching accommodation, as well as the need of more work-rooms, class-rooms, and lecture- 


\section{Sedgwick Memorial Museum 327}

rooms. It was of course proposed to build a Sedgwick Memorial Museum, and there were, as usual, several Syndicates.

The first list of subscriptions to the Sedgwick Memorial Museum was issued in 1874, and in June of that year a (11) Syndicate was appointed "to collect information as to the space and accommodation required for the new Geological Museum." This Syndicate was informed that $£ 10,500$ had already been subscribed, but they held the opinion that "this sum would be far from sufficient for the erection" of a Museum of the size they thought necessary. Professor Hughes had estimated that the total number of square feet required would be 13,700.

Four years later, in 1878, the Sedgwick Memorial Committee communicated to the Vice-Chancellor that they had now at the disposal of the University a sum approaching $£ 12,000$ for the Memorial to the late Professor Sedgwick, and a further (12) Syndicate was appointed, in December 1878, to consider the question of the best site for the Museum, and to obtain plans for the buildings. This Syndicate was requested to report to the Senate before the end of the Academic year, 1878-1879, but apparently their deliberations were prolonged, for the University granted them an extensionfirst of all to the end of the Easter Term, 1880; then to the end of the Easter Term, 1881; and finally to the end of the Easter Term, 1882. This Syndicate finally reported on 31st May 1882, to the effect " that the difficulty of providing a site for the Geological Museum, without unduly curtailing the space available for other Departments of Science, has prevented them from submitting to the Senate any proposal for building; but that recent acquisitions of ground in the neighbourhood of the New Museums ... gave them reason to hope that this difficulty may be removed." They therefore asked for a further prolongation until the end of the Easter Term, 1883.

On 24th May 1883 they again reported, and this time in favour of building the Museum on a site approximately the same as that now occupied by the Medical Schools. It will be recollected that it was then contemplated that the Chemical 


\section{F. as Secretary to the Museums}

School was to be erected on the site of the Perse Almshouses. A good deal of controversy took place as to the precise position of the Geological Museum, some members of the Senate feeling that it should be as near as possible to the Museum of Zoology, whilst others attached little importance to this suggestion and indeed disliked it.

On the 23rd June 1883, another (13) Syndicate was appointed to carry out the recommendation of the Syndicate that had reported on 24th May 1883, and whose Report had now been confirmed by the Senate. This Syndicate was reappointed in the following year, and issued their first Report on the 7 th February 1885. They had considered both the Chemical and the Geological buildings. In their earlier Report, that of the 7th February 1885, they confined their attention entirely to the Chemical Laboratory, and ultimately estimated its cost at about $£ 31,000$, and, as we have seen, ${ }^{1}$ the Chemical Laboratory was commenced shortly afterwards. After some criticism the Syndicate reconsidered their Report, and issued an amended version on 29th April 1885, and this Report was confirmed on the 15th May of the same year. During November 1886 Professor Hughes notes that this Syndicate had expired. But on the 10th January 1886, still another (14) Syndicate was appointed "to obtain plans and estimates for the Geological Museum on the site proposed in the Report dated 24th May 1883." 'That site, it will be recollected, faced the northern end of Tennis Court Road. This Syndicate seems to have lapsed without any further result, but a large number of pamphlets and fly-sheets were issued; some again advocating the erection of the Museum as close as possible to the Zoological Museum, whilst others held that if it were possible to purchase part of the Downing grounds, a position on this site would better suit the purposes of the Geologists. The (14) Syndicate having now lapsed, the next move was with the Council of the Senate, and a Grace proposing that the Vice-Chancellor be authorised to enter into negotiations with the authorities of Downing College was carried by 80 placets against 71 non-placets.

${ }^{1}$ p. 313. 


\section{Geological Museum}

'I'he negotiations with Downing College, however, fell through in October 1887, and a week later the Council recommended another (15) Syndicate to procure, if necessary, fresh plans for the erection of the Sedgwick Memorial Museum on the site to the east of the new Chemical Laboratory. Plans suitable to this site were put in the hands of the Senate by the division of the Lent Term, 1888. On 5th March 1888, still another (16) Syndicate, known as the Building Sites Syndicate, reported on a scheme for the future appropriation of all the sites available for buildings in the neighbourhood of the New Museums. This (16) Syndicate was of opinion that there was sufficient area between the new Chemical Laboratory and the Museum of Human Anatomy (the old Octagon) to admit of the erection of a Geological Museum which would satisfy the requirements of Geology.

The Council of the Senate, however, reported on 11th June 1888 that they had received a Minute from the Financial Board stating that they were "of opinion that at the present time it would not be prudent to assign any sum for a new Geological Museum. Under these circumstances, the Council feel they can take no further step at present." But on the 18th December 1890 they appointed yet another (17) Syndicate to consider to what University purposes the Perse School site should be put, "and in particular to consider a site for the Sedgwick Memorial Museum." This Syndicate was to report before the end of the Easter Term, 1891. Accordingly, on the 20th February, they issued a long and detailed Report, in which they reaffirmed the desirability of erecting the Sedgwick Memorial Museum between the old Anatomical Schools and the eastern end of the Chemical Laboratory. The part of their Report referring to the Museum was, however, threatened with a non-placet, and apparently was withdrawn. The nonplacets had asked that for once a (18) Syndicate should be appointed consisting of members of the Geological Staff, and this was almost done, for on the 30th April 1891 the Vice-Chancellor, with Professor Hughes, Professor Lewis, Mr. A. Sedgwick, 


\section{7. as Secretary to the Museums}

Mr. Marr, Mr. T. Roberts, and Mr. A. Harker, were appointed by a majority of three votes to consider a site for the new Geological Museum. This (18) Syndicate reported in favour of building from the corner of Corn Exchange Street westward to within about twenty feet of the Chemical Laboratory, and their recommendation was confirmed by Grace of the Senate on the 18th June 1891.

On the 4th February 1892, another (19) Syndicate was appointed "to obtain plans and estimates from one or more architects as they may think fit, for the erection of the Sedgwick Memorial Museum upon the site" above mentioned. By April 1892, Mr. (now Sir) T. G. Jackson, R.A., had prepared his plans and specifications for a building extending from Corn Exchange Street to within thirty feet of the Chemical Laboratory. The Report of this Syndicate, dated 11th November 1892, was not unanimously signed, and a non-placet was issued, and a second Report appeared in February 1893. The Council of the Senate, however, did not sanction Graces confirming the recommendation of this Syndicate, but put forward a Grace giving general approval to the plans prepared by Mr. Jackson. This proposal produced a sheaf of fly-sheets, but although it was non-placeted, it was carried, whereupon another (20) Syndicate was appointed on 23rd November 1893 to obtain working drawings, specifications, and tenders for the Museum, and this Syndicate was prolonged for some time, and finally on 30th October 1894 they requested powers "to reconsider that plan, and, if necessary, to substitute a new one for it." This was confirmed on the 31st January 1895.

In June 1895 the Sedgwick Memorial Museum Syndicate reported that they had inspected Mr. Jackson's amended plans, and that they regretted that it was impossible at this late period of the term to proceed further with the question. The plans were deposited in the Woodwardian Museum for the inspection of the members of the Senate.

In November of the following year (1896), a majority of 


\section{Geological Museum}

the (20) Syndicate which had been appointed just three years before recommended that the Museum be erected upon a portion of the Downing Site, the purchase of which had been by this time authorised by the Senate, and that the Grace of the Senate of June 1891, which had assigned the site on the old Botanic Garden area, be rescinded. This report was somewhat vigorously criticised in the Art School discussion, but was eventually carried by 196 placets as opposed to 42 non-placets.

In May 1897, still another (21) Syndicate was appointed to obtain plans and estimates for the erection of the Museum upon the site which has just been mentioned. As usual, this Syndicate had to be continued, and its life was prolonged to the end of the Easter Term in 1898, but by May in this year they had approved the plans and asked for power to obtain tenders and specifications. They proposed that a building should be erected at a cost of 241,500 , which included fittings and furniture, and the architect's commission and the clerk of the works' wages. In February of 1899, however, a larger scheme was adopted by the Senate, and for this it was estimated that an additional ¿2625 would be required. Of this the share of the University would be $£^{1} 17,500$, but allowing for contingencies the Financial Board estimated that $£ 21,000$ would about provide for the larger scheme accepted by the Senate.

On the 16th February 1899, Mr. Jackson's larger scheme was approved by 96 votes to 58, and powers were given to the Syndicate to obtain the necessary specifications and tenders.

At last, on the 26th October 1899, another (22) Syndicate was appointed to superintend the erection of the Museum, and they were requested to co-operate with the Law School and Library Buildings Syndicate, and the Botany Building Syndicate, since all these buildings were being set up on the new Downing Site at approximately the same time. In their final Report it appeared that the cost of the building, 


\section{Z. as Secretary to the Museums}

including the fees of the architect and of the clerk of the works, came to a little below $\mathfrak{L} 50,000$. Towards this sum rather

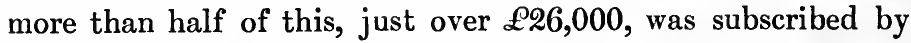
the Sedgwick Memorial Trustees $;^{1}$ the Common University Fund furnished $\mathfrak{L}^{13,000}$ and the Syndics of the Press

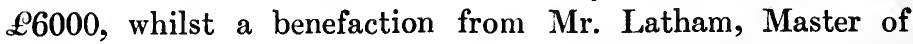
Trinity Hall, for the beautifying of the building added about $£ 900$.

That these Syndicates were exceptionally numerous, and in fact that it was normal to have one in session although little came of its deliberations, is shown by the pathetic outcry of Professor Hughes' Annual Report for 1899: "There is not even a Syndicate sitting to consider the disposal of the money subscribed with a view to erecting a new Museum in honour of Professor Sedgwick." The uncertainty when the building could be begun, and still more when it could be finished, hampered in every way the activities of the Department.

Geology has waited long for the Sedgwick Museum, but it has not waited in vain. When, on 1st March 1904, King Edward VII, accompanied by Queen Alexandra and Princess Victoria, opened the Sedgwick Museum, he opened the most spacious, the most stately of all the scientific Museums in the University.

Professor Hughes records in his Annual Report for 1904 that the vast collections stored in Cockerell's Building were now transferred to the Sedgwick Museum, and partially arranged. In the same Report we learn that he was giving a helping hand to Geography, which has even yet not found a home for itself. The space set free in Cockerell's Building naturally went to the Library. Owing to the generosity of the Goldsmiths' Company, the Syndics of the University Library have been able to fit the old Woodwardian Museum

${ }^{1}$ Whilst all these Syndicates had been talking, the original fund collected in Professor Sedgwick's honour had been working, and had almost doubled itself in about thirty years. 


\section{Mineralogy}

with iron bookcases in which about 400,000 volumes can eventually be stored.

To return for a moment to Mineralogy. As we have seen, ${ }^{1}$ a Syndicate had been appointed in February 1853 to advise how Dr. Walker's botanic garden might be legally acquired by the University, and to prepare a scheme for new museums and lecture-rooms. In their Report they include a most careful and detailed account of the requirements of the different departments. They tell the Senate "that the Mineralogical Museum is now arranged in a room under the new wing of the University Library, which is by no means sufficient for the display of the Collection. But the Professor is compelled to carry on his private investigations in the vaults below ... and he is unprovided with a laboratory." I do not know at which end of Cockerell's building this room was, but whichever end it was the Professor of Geology coveted it. The suggestion mentioned above to erect a new building was well received by the Senate but rendered nugatory by want of funds, and so the proposal lapsed till early in the sixties, when there seems to have been more money. After a good deal of discussion and some delay, the Mineralogical Museum was installed by 1866 on the first floor of the western wing of Salvin's building. With the solitary exception of the Museum of Comparative Anatomy, it alone occupies the rooms where it was placed forty-six years ago.

The end of the nineteenth century and the beginning of the twentieth was a period of great building activity. Not only was the Sedgwick Memorial Museum rising from the ground, but the new Botanical School, the Medical School, and the Squire Law Library and the Lecture Rooms were all in process of construction. The Professor of Botany had been annually complaining of the overcrowded state of his laboratory, and he records in his 1898 Report that a Syndicate has been appointed "to consider what steps should be taken for the erec-

${ }^{1}$ p. 303. 


\section{Z. as Secretary to the Museums}

tion of new buildings for the Department of Botany." In the following year, he reports that the Syndicate are in favour of placing the building on the Downing site, and that the Council have reported in favour of apportioning a sum of money for building a Museum, Herbarium, Library, the necessary Lecture Rooms, Laboratories, Workrooms, and Research Rooms, from the Benefaction Fund. The position approved by the Senate was on the Downing site, about equidistant from the east and west boundary. Mr. W. C. Marshall, M.A. (Trin.), was chosen as architect; the tender was accepted in March 1901, and the building was opened by King Edward VII on 1st March 1904. On the same day, besides the Sedgwick Museum and the Botany School, the King opened the Squire Law Library and the Medical Schools.

A Syndicate had been appointed, in March 1899, to consider what steps should be taken to erect a Law School and Library on part of the Downing ground. In May 1900, they reported in favour of "the north side of the ground-the Library to be built adjacent to the Geological Museum, and the School on part of the remaining north front of the ground adjacent to the Library. They are happy to report that they have received an extremely munificent offer, from the Trustees under the will of the late Miss R. F. Squire, to defray the cost of the Library and of furnishing it with internal fittings." It was the wish of the 'Trustees that the Squire Law Library should "form a distinct and self-contained part of the whole building," though they raised no objections to the main entrance and staircase affording access to the professors' rooms and class rooms. As is mentioned above, ${ }^{1}$ a certain sum of Mr. Henry Latham's benefaction was devoted to the embellishment of the buildings on the Downing Street site. The expense of the porter's lodge which was then erected and of the Law Lecture Rooms was borne by the University. The proposals of the Syndicate were accepted by the Senate in June 1900. The University was 


\section{Patbology}

fortunate enough again to secure the services of Mr. T. G. Jackson, to whose genius we owe this fine entrance to the Downing grounds, now being fast covered with Laboratories and Museums.

A building was also rising on the other side of the street. We have seen ${ }^{1}$ that, when Chemistry vacated the old buildings in the north-east corner of the southern court, Pathology stepped in. The accommodation, however, was not only inadequate, but bad. Part of the building dated from 1786, and all of it was in poor repair, insanitary, and in just the sort of state that a pathological laboratory should not be. Professor Sims Woodhead, who had succeeded Professor Kanthack in 1899, reports in his Annual Report for 1899 that "the buildings are very difficult to keep in repair," and deprecates spending further money on them. The state of the Octagon, which dated from 1832-3, was even worse. After the Human Anatomists had vacated it in 1891, it had in the main been used for the teaching of Surgery and Obstetrics. Here also was a room used by the Lecturer in Medical Jurisprudence, and here possibly one or two other Medical 'Teachers had their centre, but whoever worked there did so under conditions of great discomfort. "It is impossible to keep the roof in repair, and as a result the ceilings and walls are always in one part or another soaked with wet, and sometimes the rooms and passages are flooded." Thus writes Mr. J. Griffiths, the Reader in Surgery, in his report for 1898. In the following year, he mentions that the presence of dry-rot is more extensive than ever; and that whilst the rain is dripping in from above the dry-rot is creeping up from below. The sole accommodation for the Regius Professor of Physic (Sir George Paget) ${ }^{2}$ was a tiny room at the western end of the Philosophical Library, and Dr. Paget until he died made an amiable and annual protest against this absurdly inadequate apartment.

Perhaps the Downing Professor of Medicine was better off ${ }^{1}$ p. 314. 2 1872-1892. 


\section{F. as Secretary to the Museums}

than the others, for he had hired certain rooms from Downing College, and there had organised a small Pharmacological Laboratory. It was felt on all sides that something must be done, and, in March 1899, a Syndicate was appointed "to consider what steps should be taken for the erection of new buildings for the Medical School." The site had already been fixed by Grace in November 1897. It ran along the north side of Downing Street, leaving a considerable gap between it and the east end of the Chemical Laboratory, until it reached Corn Exchange Street; and here the plan was to continue the building up to the south-east corner of Fawcett's second building, but funds proved insufficient, and less than a third of this "return" has been built. The site of this has however been cleared; and all the old 1786 buildings have now gone. It is greatly to be hoped that the Medical School will in the near future be completed.

The 1899 Syndicate recommended that the subjects of Medicine, Surgery, Pathology, Pharmacology, and Public Health be all accommodated in the proposed new building, and that a Museum, which in view of Sir George Humphry's great services to the University should be called the Humphry Museum, be erected. Mr. E. S. Prior, M.A. of Gonville and Caius College, now Slade Professor of Fine Art, was chosen as architect, and tenders were accepted in May 1901. Since on the site allotted to the new Schools there were buildings in which Pathologists, Surgeons, etc., were then working, it became necessary to find temporary accommodation for them whilst the existing buildings were being pulled down and the new ones put up. As usual, allied departments did what they could by lending lecture rooms, etc., but most of the pathological work was transferred to the offices remembered by many of us as the first home of the Cambridge Scientific Instrument Company in St. Tibbs' Row. Surgery however retired to 16 Mill Lane and the adjoining granary, where also the pathological specimens were carefully stored.

The new building proceeded at a rapid pace, and, although 


\section{Scbool of Medicine}

not completed, was in a sufficiently advanced state to be opened by the King on his visit of 1st March 1904. Considerable sums were contributed to its cost from outside ; over $\mathfrak{2 6 0 0 0}$ came from the Endowment Fund, and Lady Humphry's family and a few friends defrayed the expenses of fitting up the Humphry Museum. Although the existing Medical Schools are barely two-thirds the size at first contemplated, they manage in a very cramped sort of way to accommodate Medicine, Surgery, Pathology, Pharmacology, Medical Jurisprudence, Hygiene, Vaccination, and even to find a corner for the Reader in Ethnology, and, in a larger but very inconvenient Laboratory under the Humphry Museum, for the Quick Professor of Biology, whose chair was founded in 1906. The overcrowding is however very apparent, and it is hoped that before long the gap opposite the Arcade will be filled in, when this piece of Richard Walker's Botanic Garden will again bear University buildings as it did one hundred and twenty-seven years ago. When this gap is filled, the site he bought and gave to the University in 1762 will, practically, be fully occupied. Before passing on, it should be mentioned that the authorities of the Medical School combined in 1909 with the authorities of the Agricultural School and those of the School of Physiology in purchasing five acres of land on the Milton Road for the purposes of an experimental plot for animal breeding, animal diseases, etc. This area is now adequately provided with farm buildings and a caretaker's house.

Nor must we forget to mention that the staircase in Salvin's building between the Zoological Lecture Room and the Philosophical Library was removed in 1908, and in its place three fair-sized rooms were constructed. The groundfloor room is at present used by the Arthur Balfour Professor of Biology. The others are allocated to the Department of Morphology.

The next building we have to deal with, the School of Agriculture, is the result of a remarkable movement started 


\section{F. as Secretary to the Museums}

by a letter, dated 25th July 1890, addressed by Mr. Henry Chaplin, then President of the Board of Agriculture, to the eighth Duke of Devonshire, our Chancellor. The purport of the letter was to ask if the University could see its way to undertake the training of agricultural teachers and experts. Although, in the opinion of some members of the Senate, this subject was not at all a proper study for University instruction, a Syndicate was appointed which in time suggested a fairly complete scheme for a Department of Agriculture. However, as usual, there was little or no money available, and after reconsideration a revised and more modest scheme of an Examination for a Diploma in Agriculture was put forward and accepted by the Senate in November 1893. It was obvious that if this Examination should prove a success, Cambridge must provide teaching. Professor Liveing and Professor Hughes, who had both taken the keenest interest in the movement, interviewed the authorities of the County Councils of the Eastern Counties, and from these interviews arose the Cambridge and Counties Agricultural Education Committee. 'This Committee, with the aid of certain moneys granted by the Board of Agriculture and by some of the County Councils, started in January 1893 with one or two teachers to instruct seven students. In six years the numbers had grown to twenty-five, and then the University took the work over.

One of the earliest benefactors to the School was Sir Walter Gilbey, who gave a sum of 225 a year for twenty-one years to endow a Lectureship in the History and Economics of Agriculture (1896), and later (1898) an endowment of $\$ 200$ for ten years to provide the stipend for a University Lectureship in Agriculture. This was coupled with the condition that the University should institute a Special Examination in the subject, so that a student might graduate in Agriculture. Such a condition needed consideration, and whilst it was being considered two events happened. The Secretary of the Board of Agriculture and Fisheries intimated that, if the subject were 


\section{School of Agriculture}

officially recognised, the Board would endeavour materially to increase its annual grant; and, secondly, the Drapers' Company offered to provide the stipend of a Professor for ten years, should the University establish a Professorship of Agriculture and create an Agricultural Department. These proposals were formally accepted by Grace of the Senate in March 1899.

To the first Professor, Dr. W. Somerville (1899-1902), and to the help of Mr. W. A. Macfarlane-Grieve of Clare College, the University owed its first experimental farm, at Impington. Some years later the Impington Farm was given up, and a holding of 230 acres belonging to Trinity and Clare Colleges, near to the Observatory, was taken. Contiguous to the eastern boundary of this farm is a plot of ground on which a house and other buildings are now being erected for the use of the Balfour Professor of Biology.

Under the second Professor, Mr. T. H. Middleton (1902-7), efforts were made to raise money to pay for a permanent home. Up to April 1910 the Department had been housed, thanks to the kindness of Professor Liveing, in some half dozen rooms of no great size, in a basement under the large students' room in the older (1889) block of the Chemical Laboratory. The need for new buildings was pressing, as the accommodation was unsuitable and entirely inadequate. The Drapers' Company, with its habitual generosity, offered $£ 5000$ "provided that $£ 5000$ could be raised elsewhere." The Chancellor, the late Duke of Devonshire, with the assistance of the Cambridge University Association, raised the second $£ 5000$ before his last illness. He had, indeed, the matter much at heart, and not long before his death asked his nephew to help in getting the remaining $£ 10,000$ for the building, and allowance for upkeep. The present Duke readily undertook to help, and in a comparatively short time the amount was collected. A site had been assigned to the south, and parallel to the School of Botany, and plans were prepared by Mr. Arnold Mitchell, F.R.I.B.A. They were accepted, the building was finished, and on 26th April 1910 it was opened 


\section{F. as Secretary to the Museums}

by the present Duke of Devonshire, who had helped so materially in rendering its erection possible. Although opened to students less than four years ago, the press of work-some of it undertaken for the Government-and the increase in the numbers of students, has squeezed the Reader of Forestry and his Department out of the building, and has already necessitated a considerable increase in the accommodation. Additional buildings forming an extension of the old School towards Tennis Court Road are now (1913) all but complete.

In the meantime the Department of Forestry has taken temporary refuge in an ancient house close to the northern end of Free School Lane, but a site has been assigned to it in the south-east angle of the Downing site, plans have been prepared, and the buildings for our School of Forestry are now rising.

When Agriculture vacated the rooms they had so long used in the basement of the Chemical Laboratory, they were adapted for use as a Metallurgical Laboratory. In 1908 the Goldsmiths' Company most generously gave $\mathfrak{\& 1 0 , 0 0 0}$ to endow a Goldsmiths' Reader in Metaliurgy, and in 1910, when Agriculture moved out, the Company increased the gratitude felt towards them by the University by making the necessary alterations in, and by providing the necessary fittings for, the Metallurgical Laboratory.

Three buildings remain to be mentioned on the Downing site. One of them, the Laboratory of Psycho-physics, is completed; of the other two, such portions of the Museum of Archæology and Ethnology and the new Physiological Laboratory as it has been found possible to erect are approaching completion.

The Museum of Ethnology was very dear to J.'s heart, in fact it was one of the many things he helped to start in the University. Writing on the 27th April 1883 in his Annual Report, J. records :-

"In the last place I have to mention that my friend A. P. Maudslay, M.A. of 'Trinity Hall, has deposited in 


\section{Museum of Etbnology}

my charge a portion of the large and important Collection of arms, dresses, ornaments, domestic utensils, pottery, and other objects which he made in Fiji and the adjacent islands. It is more than probable that he will present the whole Collection to the University at no distant date; and it will serve as the nucleus of a Museum of Ethnology, the importance of which in connection with Biological studies is now generally recognised."

For a time J.kept the Collection in his private room at the Museums, but the following year the Museum of General and Local Archæology and of Ethnology was opened, and an unsuspected wealth of ethnological objects was gradually revealed. The Maudslay Collection, greatly increased at a later date, still forms one of the most important gifts to the Museum. At best the Museum was but a long narrow gallery with two or three inconvenient rooms attached to it. For years it had been overcrowded, and for years many of the more important objects have been stored away in a disused malting-house at Newnham. It was felt that something must be done, yet nobody did anything. Finally the Curator, Baron Anatole von Hügel, who has devoted his life to the Museum, took the matter in hand and, almost entirely by his own exertions, got together the money for the new Museum. The generous contributions of the old and well-known Cambridge family of Foster alone made the building possible.

Such portion of the building as it has proved possible hitherto to put up contains a large Museum with a wide gallery, certain unpacking rooms and workrooms, and two or three private rooms for the Curator and the Reader in Ethnology. The building extends from the west side of the Law School up to the corner of Tennis Court Road, and then turns a little way south along that thoroughfare. The plan, like that of the neighbouring Law School, is by Sir. T. G. Jackson, R.A. The Collections began to be moved into the Museum in 1912.

The Laboratory of Psycho-physics, which was begun in May 1911, and is now completed, is again due to the energy of one 


\section{F. as Secretary to the Museums}

man, Dr. C. S. Myers, who by his own exertions collected just under $£ 4000$, the majority of which was given by his own family. The handsome building is a splendid contrast to the decayed, rat-infested cottages in Mill Lane, in which, in spite of their surroundings, Dr. Myers, Dr. Rivers, and others have done such remarkable work. The plans for this building, and of the new Physiological Laboratory, and of the last named were again due to Sir T. G. Jackson.

The fact that Physiology will shortly be able to move across Downing Street is again largely due to the generosity of the Draper's' Company, who have done so much for the Department of Agriculture. In 1910, they offered the University the sum of $£ 22,000$, which was, after some discussion, dedicated to a new laboratory for Physiology. This sum does not, at present, permit the building of Lecture Rooms, and the Department of Bio-Chemistry is not provided for; but since 1911 some more thousands have come in, and it is hoped shortly to complete the building in all its branches.

This completes the account of the Downing site. On the old Botanic Garden site, or rather on the site of $\mathrm{Mr}$. Mortlock's garden, are two large buildings, recently erected, the Examination Rooms and the new Lecture Rooms. The former covers the eastern side, and very nearly fills the northern boundary of the Court. It was opened in 1909, and contains two rooms, both 106 feet in length, but the larger is 51 feet wide and 30 feet high; the smaller, which can be divided into two, is 30 feet wide and 16 feet high. The Examination Rooms were designed by Mr. William Marshall in a style of restrained simplicity, which harmonises well with the Salvin building opposite and the Fawcett building on the east.

The new Lecture Rooms, the last building we have to do with, were first used in the Lent Term 1911. It is intended for Literary, Historical, Economic, Philosophical, Mathematical, and other lectures. These Lecture Rooms have a handsome and well-proportioned façade, too much of which is unhappily hidden. The architect was Mr. George Hubbard, F.S.A. 


\section{Lecture Rooms}

With the exception of an entrance court from Bene't Street, roughly coinciding with the area of the Lady Margaret Professor of Divinity's slaughter-house, which lay between them and the Rayleigh Wing of the Cavendish Laboratory, the Mortlock site is entirely built over.

When the Plumian, the Lucasian, and the Lowndean Professors moved into the somewhat inadequate quarters assigned to them in these new Lecture Rooms, the former rooms of the Plumian and Lowndean Professors, which had been made into one some years ago, were, together with the Philosophical Society's Council Room, used as Lecture Rooms for the advanced class in connexion with the Department of Morphology. And at the time of writing (1913), the Optical Lecture Room, so long used by the Lucasian Professors, is being converted into a spacious Library, where the Balfour, the Newton, the Norman, and other zoological Libraries will be housed.

This chronicle, inadequate as I know it to be, is a record of a great growth-I think an unparalleled growth-of buildings devoted to the advancement of Natural Science in our country. They have been built up by many hands, but no one had a larger share in their building than $\mathrm{J}$. 

$-n+4 x^{2}=$

$f x=40 \frac{1}{45}$

istis

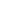




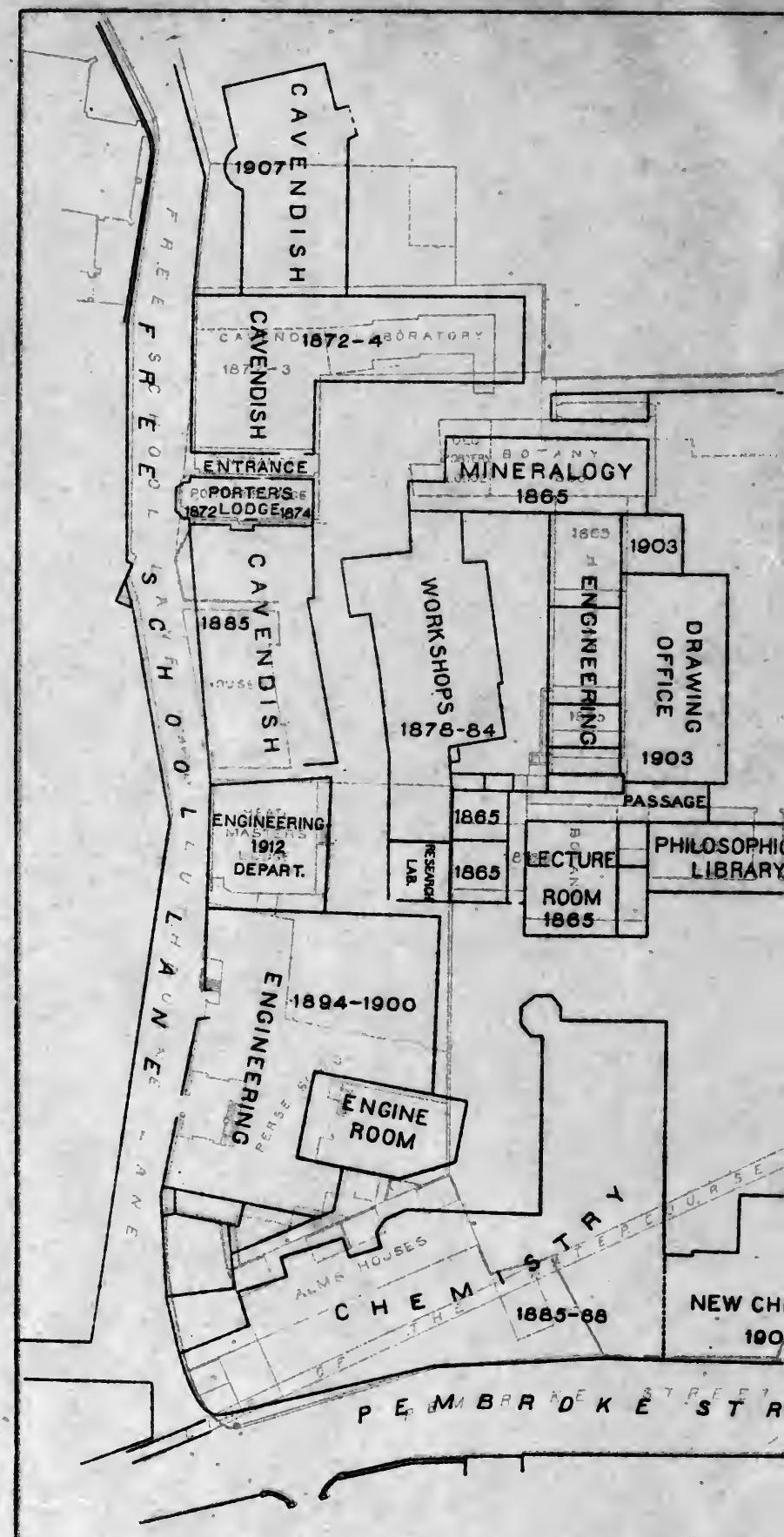

THE MU 


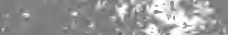

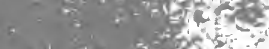

$-a^{2}+x_{2}+\frac{3}{2}+3$

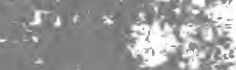

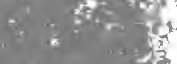

(e) $=-5$

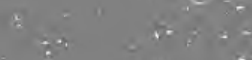

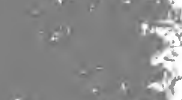

$\therefore \quad$ is $4 x$

$=-4=\frac{5}{5}$

$\leftrightarrow \rightarrow-$

$-x$

8

$\therefore \sum^{2}$

$=\frac{2}{3}$

$2 \int^{2}$

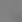

$=$



\section{IN DEX}

A.D.C., 93, 102 ; J. elected treasurer, 130 ; his work for, 130,131 ; writes plays for, 238-241; anecdotes of J. at, $239-240 ; 255$

Abernethy, John, 2

Abney, Sir William, 182

Academy, the, 127

Ackermann, R., 300

Acts and Opponencies, 39

Addenbrooke's Hospital, 19

Adrienne Lecouvreur, 105

Affleck, Lady, 18

Agamemnon, 138

Agassiz, Louis, 105, 275

Agriculture and Fisheries, Board of, 338,339

Agriculture, School of, at Cambridge, $337-340$

Airy, Sir G. B., 115

Ajax, 138, 225, 228

Alaska Commercial Compàny, 276,287

Albert, Prince Consort, 51; his installation at Cambridge, 61-64; 173,174

Alberti family, 202

Alderson, F. J., 69, and note

Alexander, Wm., Bp., 52

Alexandra, Queen, 176, 182, 332

Algeria, 118

All Saints' Church, 21, 95, 257

Allport, M., 269

Alps, 77-80, 155

Amiens, 161

Amsterdam, 152

Anatomy, Comparative, Museum of, its history, 261-275 ; Dr. W. Clark's efforts for, 263; Macartney collection bought 1836, 264; Swainson collection of birds acquired 1840, ib.; Blackwood collection presented 1846, ib.; Groodacre Museum of Vertebrate Animals acquired 1863, ib.; collections removed from Anatomical Schools to present quarters, $1866, i b . ; J$. appointed Superintendent, ib.; R.
T. Lowe's and C. Darwin's collection of fishes arranged, 264, 265; Sir Busick Harwood's collection, 265 ; Schröder van der Kolk collection presented by Prof. Humphry, $i b$.; Pevensey whale acquired, ib. ; Strickland collection presented, 1867, 266; Woodward collection of shells arranged, 267 ; catalogue of the Cambridge collection of invertebrata, prepared by W. S. Kent and J., 1868, ib. ; Sir E. Newton's skeletons of the Dodo and Solitaire presented, 267, 268 ; Swainson, Strickland, Selby and other collections arranged, 1869, 268 ; skeleton of a sea otter presented by Prof. Humphry, 269 ; Tasmanian marsupials presented by M. Allport, $i b$.; collections of invertebrata made during voyage of the Beagle presented by $\mathbf{C}$. Darwin, 1870 , $i b$.; collection of reptiles, birds, \&c., from C. F. Tyrwhitt Drake, $i b$. ; library in connexion with, commenced, $i b$.; Hepburn collection given, 270; Brown collection of British insects acquired $1871, i b$. ; collection of insects arranged by G. R. Crotch, $i b$.; classes for practical work in Comparative Anatomy first begun in $1871,270,271$; MacAndrew collection of shells acquired 1873, 272 ; post of Demonstrator to the Professor of Zoology and Comparative Anatomy established, 273; Strickland Curatorship founded 1874, ib.; O. Salvin first Curator, $i b$. ; Crotch collection of European coleoptera acquired, 274; skeletons of African mammals presented by T. E. Buckley, ib. ; Hamilton collection presented 1875, ib.; new buildings commenced 1876, completed 1878, 275. 


\section{Index}

Anatomy, Comparative. See also Zoology and Comparative Anatomy, Museum of.

Anatomy, Human, Museum of, 3, 4, 14 ; housed in the Octagon, 297, 314,315 ; new buildings completed, 1891,316

Ancien Régime, 205

Anti - Dining - in-Hall - on - Sunday-because-of-the-Squash Club, 29

Antiquarian Society, see Cambridge Antiquarian Society.

Antiquaries, Society of, 139

Arcade, the, 299 note, 337

Archæological Institute of Great Britain, 141, 158, 173

Archæology, Museum of General and Local, and of Ethnology, 340, 341

Architectural History of the University and Colleges of Cambridge, 11, 55; J. at work on the, 124,125 ; origin of the, 141; published in 1886 , $142,143,144$

Ardinghelli family, 203

Arles, 108

Arrington, Cambs., 4

Arsenal, Bibliothèque de l', 152, 169

Arthur, the decorator, 101

Arts School, 302, 331

Asquith, Rt. Hon. H. H., 199

Assisi, 166

Assommoir, $L, 167$

Athanasian Creed, 113

Athens, 181

Atkinson, T. D., 162

Auxerre, 156, 199, 200

Aysgarth, 142

Aytoun, W. E., 30, and note

Babington, C. C., 60

Baillie, Matthew, 10

Baird, S. F., 287

Baker, Sir Samuel, 267

Balfour, F. M., 120 ; his death, 135, 136 ; memorial to, 137,$138 ; 158$, 159 ; his classes in Animal Morphology, 274, 276, 277, 307, 311; appointed Professor of Animal Morphology, 280; 308,

Balfour, Gerald, 212

Balfour, Reg., 166, 192

Balfour Library, 269, 282, 343

Balzac, H. de, 189

Bancroft Company, 246, 247

Barante Château, 196, 197

Barclay's Bank, 161, 310

Barnay, 225
Barnes Pool Bridge, 57

Barnwell, 163, 200, 307

Bartet, Mlle., 234, 244, 251

Bartholomew, A. T., 185, 187

Barton Road, 44

Bateman Street, 28

Bateson, W. H., 294

Battersea, Lord, 240

Bavaria, 76

Beadon, Mrs., 90

Beagle, H.M.S., 259, 265, 269

Belgium, 15

Belgrade, 177, 178

Bell, Thus., 259

Benefactors, Commemoration of, 181

Bene't Street, 343

Benson, A. C., his reminiscences of J., 227-230

Benson, F. R., 252

Bentinck, F., 254

Bentley, Richard, 93, 185

Bering's Island, 286, 287

Berkeley, Hon. C. P. F., 277

Berlin, 99, 121-123

Bernard, St., 157

Bernbardt, Sarah, 234, 242

Besançon, 154

Besant, W. H., 124

Beverley, R. M., 33

Beverley, Yorks., 158

Beylard, M., 131

Biarritz, 127

Bibliothèque Mazarine, 169

Bibliothèque Nationale, 76, 152

Bijou Theatre, Camb., 161, 162

Biology, Balfour Prof. of, 337, 340 ; Quick Prof. of, 337 ; School of, 4, 5

Bird Room, see under Anatomy, Comparative, Museum of, and Zoology and Comp. Anat., Mus. of,

Birds of Aristophanes, 225, 228

Blackman, F. F., 304

Blackwood, Capt. F. P., 264, 268

Blomfield, Bp., 2

Boccaccio, G., 202

Bologna, 201

Bond, Dr., 61, 67

Bonham, Sir Eric, 122 note

Bonham, Sir Geo., 167, 177

Bonham, Lionel, 122 note

Bonham, Louisa, Lady, 114, 118, 168, and note

Boni, Giacomo, 222

Bonney, T. G., 90

Bordeaux, 212

Borghese, Prince, 168

Borgia, César, 150 


\section{Index}

Borgia, Lucrezia, 150

Botanic Garden, 14, 82, 271, 297 ; its history, 298-301; removal to Trumpington Rd., 302, 303 ; new buildings on the site of the old, 304-309; purchases made by the University to round off the site, $309-311$; 331, 342

Botany School, 302, 303, 304 ; rooms added to the Herbarium, 1884, 312 ; moved to Downing Street, 1903, $318,319,320$; 333 ; opened by King Edward, 1904, 334

Bowes, R., 81, 184

Bradshaw, H., 212, 219, 223

Brady, H. B., 284, 288, 289

Brandt, Prof., 287

Braybrooke, Lord, 165, and note, 182

Bressant, J. B. P., 234, 235, 255

Bridge Street, 21

Bridge, T. W., 115, 119 ; assists J. at the Museum, 269;276, 277, 278, 307

Brington, Northants, 80

Bristed, C. A., 86

British Association, 43, 97, 182

British Museum, 125, 275, 325

Brittany, 145

Brohan, Madeleine, 234

Brookes' Museum, 263

Brookfield, C., 239, 240

Brou, Church of, 153, 156

Brougham, Lord, 197

Brown, H. F., 201

Brown, J. and T., 270

Brown, John, Vice-Master of Trinity College, 37, 38

Brown, Rawdon, 222

Browne, George Adam, 37, 38

Browning, Oscar, 56, 57

Browning, Robert, 221

Buchanan, Sir Andrew, 112, 114, 277

Buchanan, Edward, 99, and note, 112

Buchanan, Sir Eric, 112

Buchanan, Frances Matilda, see Clark, Frances Matilda (Mrs. J.)

Buchanan, Rt. Hon. Sir George, 114, 125 , and note

Buckley, T. E., 267, 269, 274

Budgett, J. S., 181, 182, and note

Bulgaria, 178

Bullar, J. F., 275, 276

Burghclere, Lord, 238, 239

Burke, Edmund, 9

Burney, Fanny, 8

Burwell Fen, 283

Butler, H. M., 90
Butler, Samuel, $\uparrow$ 1902, 81

Byron, Lord, 2, 3; his Childe Harold, $106 ; 179,189$

Calanzuolr, of Bologna, 263

Caldwell, W. H., 282

Calverley, C. S., 87, 90

Cam, River, 22, 83, 129

Cambridge and Counties Agricultural Education Committee, 338

Cambridge Antiquarian Society, 125, 139,145

Cambridge: Brief Historical and Descriptive Notes, 15

Cambridge Described and Illustrated, 163

Cambridge Natural History, 149

Cambridge Philosophical Society, 47, 139 ; history of, and its Museum, $257-261 ; 267,268,278$

- Library, 257; removed into its present quarters $1881,278,309$; J.

librarian to, 295, 296; 297, 304

Cambridge Portfolio, 257

Cambridge Review, 18 note; appreciation of J. in, 218

Cambridge Tart, 34

Cambridge University Association, 298, 339

Campbell, Frank, 54

Campbell, Mrs. Patrick, 254

Campbell, Captain, 53

Campbell-Bannerman, Sir H., 208

Cannes, 145

Canning, Sir Stratford, 114

Canterbury, 153, 162

Capstick, J. W., 203

"Cardinal's Cap," the, 20

Care of Books, The, J. begins on, 124 ; publishes it in 1901, 153,168, and note, 169, 172, and note

Carter, James, 268

Cartmell, J., 60, 294

Carus, W., 62, 64

Cassell, Petter, \& Galpin, Messrs., 99

Caste, 246

Castle Hill, 82

Cavendish Laboratory, gateway in, 300, 301 ; Professorship of Experimental Physics established, 1871, $305 ; 306,309,312$; Rayleigh wing of, $299,305,310,343$

Certaldo, 201-203

Cesena, 153, 167

Chaise-Dieu, La, 185

Champs Elysées, 129 


\section{8}

Chancellor's Medals, 41

Chaplin, Henry, 338

Charteris, Hon. A., 240

Chemical Laboratory, 301 note; addition to, in 1872, 306 ; new buildings, 1889,313 ; further extensions, 313 , $314 ; 328$

Chesterton, 44

Chevallier, Temple, 14

Childe Harold, 106

Chinese pig described, 72, and note

Chisendale-Marsh, Mr., 130

Christ's College Lodge, 14, 67

Christ's Piece, 82

"Christopher Inn," the, 57

Church Congress, 209

Cicero, 76

Citeaux, 154 ; library of, 152, 153

Clairvaux, library of, 152,153

Clare College, 82, 153

Clare Hall Piece, 44

Clark, E. C., 91

Clark, Edward Mellish (J.'s elder son), his birth, 120; at Harrow, 145 ; his illness in 1892,148 ; visits France with J. in 1895,157 ; at Davos, 166 ; his marriage, 1901, 169 ; removes to Scroope House 1906, 190; at Royat with J., 192

Clark, Frances Matilda (Mrs. J.), her engagement to J., 1873, 112; influence on J., 113; her parents, 114 ; marriage, 118 ; letter on a performance at the A.D.C., 131-133; her illness in $1888,144,145 ; 1907,191$, 192 ; death, 1908, 200 ; work and character, 200, 201

Clark, John, M.D. (J.'s grandfather), 1 Clark, John Willis-

Life:

called "J." and "J. W.," 1 note

his ancestry, 1-15

birth, 1833, 13

early childhood, 14,15

early education, 52

boyhood, 52,53

his friendship with the Pemberton family, 53,54

at Eton, 1847-1851, 54-75

Eton schoolfellows, 69

his "Vale" on leaving Eton, 75

goes abroad with Holden, 1852, 76-80

Alpine adventure, 78-80

enters Trinity, 1852,80

his undergraduate days, 84-91

his rooms in Trinity, 84
Clark, J. W.-Life (continued)

his tutors, 85,86

visits Paris, 1853, 87 ; Germany, 87-89

elected a Scholar of Trinity, 1855, 89

takes his degree, 1856, $i b$.

tour in Norway, 90

tour in France, 1857, ib.

elected to a Fellowship at Trinity, 1858, 91

plans an edition of Aristotle's $D e$ Partibus Animalium, 93

begins to collect Cambridge literature, $i b$.

visits France and Italy, 1858-9, 94

begins his diary in 1860, 95

reads paper before the Camb. Archit. Soc. on the "Annals of All Saints' Church," ib.

lectures on "The Roman Catacombs," $i b$.

visits the Faroes and Iceland, $i b$.

visits Switzerland and Italy, 1861, 96

adventure in Italy, 96, 97

advocates a change in the hour of dinner at Trinity, 1862, 98

visits the Lakes, \&c., 1863, $i b$.

at Cassell, Petter, \& Galpin's, 99

visits Germany, 1864, $i b$.

influential in removing the Doctors' Gallery, 100

appointed Superintendent of the Mus. of Comp. Anat., 1866, 101

appointed Secretary of the Museums and Lect. Rooms Syndicate, $i b$.

visits Paris and Normandy with H. Powell, 1867, 104

his scientific friends, 104, 105

goes abroad with Henry Jackson, $1868,105-109$

death of his father, 1869, 110

takes his mother abroad, 1870, $i b$.

his engagement to Miss F. M.

Buchanan, 1873, 112

his marriage, 118

birth of his sons, 120

visits Berlin, 1875, 121-123

begins to work on the Architectural History, 1876, 124, 125

reads papers before Camb. Antiq. Soc., 125 
Clark, J. W.-Life (continued)

as Deputy Registrary, 1877-1880, 126

goes with his family to Cromer, 1878,126

writes articles on French plays for the Academy, 127

visits the Paris Exhibition, 1879, 127,128

alludes to the great storm at Cambridge, 129

elected Treasurer of the A.D.C., 1880,130

his interest in the Club, $i b$.

his unpleasant experience in the Paris mail, 1881, 133, 134

visits France, 1882, 135

stage manager for Greek plays, 138

presents bust of his father to Trinity, 138

contributes sketches of Cambridge men to the Church Quarterly Review, 1883, ib.

elected a member of the Council of Oxford Hist. Soc.. 139

Pres. of the Camb. Antiq. Soc., $i b$. moves to Scroope House, 1885, 140

publishes the Arch. Hist., 1886, 141-2

elected Pres. of the Camb. Phil. Soc., 1887-1890, 139

Fellow of the Soc. of Antiquaries, $1888, i b$.

asked to collaborate with Prof. Hughes in the life of $A$. Sedgwick, 1887, 144 ; published 1890,145

visits Sedbergh, 1887, 144 ; Dent, $i b$.; Norwich, $i b$.

begins to translate the Augustinian Observances, 1890, 145; published 1897, $i b$.

candidate for the post of University Librarian, 1889, 145, 146

elected Registrary, 1891, 146

resigns posts at the Museums, 147

visits Madeira, 1892, 148, 149

his illness in 1892,149

portrait painted by C. M. Newton, 150

visits Paris, $1893, i b$.

visits Holland, 1894, 151, 152

writes papers on libraries, 153

delivers Rede Lecture, $i b$.
Clark, J. W.-Life (continued)

visits Eastern France, 153-157

visits libraries in France, 1895-6, $157,158,161$

lectures before the Archæological Institute at Scarborough on libraries, 1895, 158

issues fly-sheet "On Degrees for Women," 160, 161

visits Paris with Mrs. J., 1897, 162

publishes his Concise Guide, 1898, 163

lectures at Hereford, Preston, Barnwell, $i b$.

his silver wedding, 1898, 165, 166

visits Italy, 1899, 166

delivers Sandars Lectures, 1900, 153

visits Rome, 1900, 167, 168

publishes 'T'he Care of Books, 1901, 153

visits libraries at Paris, 169

breaks his arm, 170,171

proposal that he should write the Architectural History of Windsor Castle, 171-174

advocates the enclosure of the Eastern Court of Univ. Lib., 175

raises fund for Clergy Training School, 1902, 176

attends coronation of Edward VII, 176

description of it, $i b$.

receives Hon. Litt.D. degree from Oxford, 177

visits Paris, 1903, $i b$. B Belgrade, ib. ; Constantinople, 178-181

criticises Report on "'The List of Benefactors in the Commemoration Service," 181

prepares Endowments of the University, 1904, 182

and Concise Guide to Ely Cathe$d r a l, i b$.

lectures before the British Assoc. on the "Origin and Growth of the University of Cambridge," $i b$.

appeals for funds for Univ. Lib., $1905,183,184$

prepares edition of Loggan's Cantabrigia Illustrata, 184

his ill-health, 184

lectures to the Library Association on the Chapel of King's 
Clark, J. W.-Lifc (continued)

College and the Evolution of the Bookcase, 184

at Royat, 1905, 184

at Paris, 1906, 185 ; Venice, 185, 186 ; Royat, 186-188; Vichy, 189

accident in London, 190, 191

at Sidmouth, 1907, 191

publishes Liber Memorandum Ecclesie de Bernewelle, 192

visits Royat, 1907-8, 192-199

his description of the Château Barante, and family, 196, 197

publisheswith A. T. Bartholomew a Bibliography of the works of Richard Bentley, 1908185

his wife's death, 1908, 200

its effect on him, 201

publishes his "Reminiscences"

in Cambridge Review, 1909, 18; reprinted in present volume, 19-51

visits Paris, 1909, 201 ; Italy, 201-203

presentation on his resigning the post of Auditor at Trin. Coll., 203

publication of the Fasciculus .Joanni Willis Clark Dicatus, 204

his arrangements for the celebration of the centenary of Chas. Darwin, $i b$.

visits Windsor, 205

writes Introduction to Fletcher's Oxford and Cambridge Delineated, $i b$.

at Royat, 205, 206

his last illness, 1910, 207-209

resigns Office of Registrary, 209

death, $i b$.

Reminiscences :

by A. C. Benson, 227-230

L. Cust, 219-227

Lord Desart, 103, 104

Henry Jackson, 105-109

W. Pollock, chap. xi., 231256

Sir H. F. Wilson, 201-203

Characteristics:

favourite phrases, $18,211,217$, $235,237,238$

his views on Greek, 80

fond of making " asides," 94

his disposition when in France, 109
Clark, J. W.-Characteristics (contd.)

an enthusiastic gardener, 140

affection for his family, 143

his political views, 159

as a lecturer, 163

his kindness and thought for others, 182, 206, 207, 215, 218, 219

fond of entertaining, 211

his dress, 213, 214

energy, 214

systematic method of keeping accounts, 214, 215

quick temper, 216, 217

power of organisation, 223, 226, 229

love of the Thames, "the sacred river," 226

love of the theatre, 231-256

At the Museums :

his collection of papers called the "History of the Museum," 262

assists his father in the rearrangement of the Osteological Dept., 1861,262

rearranges the collections in the Museum of Comp. Anat., 1865, 262

appointed Superintendent, 1866, 263

removes collections from Anatomical Schools into Mus. of Comp. Anat., 264

rearranges the Physiological Collection, 265

his pleasure at the acquisition of the Pevensey whale, $i b$.

with Prof. Newton raises money to house the Swainson and Strickland Collection, 1867, 266

with W. S. Kent prepares catalogue of the invertebrata, 1868, 267

writes on the vertebrate part of the collections, 267,268

secures the assistance of T. W. Bridge, 269

with T. W. Bridge begins to give courses of practical work, 1871, 270, 271

on the Narwhal presented by his father, 273

moves into the new buildings, $1878,1879,275,276$

becomes Secretary to the Museums and Lecture Rooms Syndicate, 
Clark, J. W.-At the Museums : (contd.) 1880,297 ; formally appointed by the Senate, $1883, i b$.

and the fire at the Museums, 1881,279

on the skeleton of Sir J. Phear's elephant, 1882, 281

begins to arrange and catalogue the exhibited portion of the invertebrata, 1886, 284

his account of Steller's "Seacow" (Rhytina gigas), 286, 287

draws attention to the overcrowding of the Museum, 1888 , 288

plans to transfer the invertebrate collection to the gallery, 1890 , 289

his resignation from the Mus. of Zoology, 1891, 291; succeeded by Dr. S. F. Harmer $i b . ;$ his appreciation of J.'s work, $i b$.; review of J.'s work, 292, 293

resignation from the Museums and Lect. Rooms Syndicate, $1891,316,317$

Clark, Lilian (Mrs. Edward), 169, 186, 207

Clark, Mary (J.'s mother), entry in her diary of marriage to W. Clark, 11 ; her character, 12,13 ; entries in diary concerning J., $13-15 ; 17$, 18,57 ; letters to J. at Eton, 58 67 ; an enthusiastic gardener, 59 ; account of the Prince Consort's installation, 62-64; description of a family, 65, 66; 138 ; her death, 140

Clark, Susanna (J.'s grandmother), 1

Clark, Valentine (J.'s granddaughter), 196

Clark, W. G., 32, 84, 85

Clark, William, M.D. (J.'s father), his life and work, 2-7; called "Bone" Clark, 3 note; 14, 18, 70, 262 ; energetic in acquiring zoological specimens for his Museum, 263,$265 ; 304$

Clark, William Henry (J.'s younger son); his birtb, 120 ; wins Scholarship at Eton, 145 ; Junior Tomline mathematical prize, 146 ; 149 ; visits France with J., 161; wins a Major Scholarship at Trinity, 162 ; passes the I. and H. C. S. Exam., 166; accepts post in the Board of Trade, $i b$. ; visits Rome with J., 167; his marriage, 183 note; 209
Clarke, Edward Daniel ("Stone" Clarke), 3, and note, 43

Clarke, Capt. H. L. W., 69, and note

Clarke, John ("Tone" Clarke). See Clarke-Whitfield, Jobn

Clarke-Whitfield, John, 3 note

Classical Tripos, 41

Clayton, John, the actor, 252-254

Clergy Training School, 176

Clermont, 194, 195

Clieveden, 72

Cockerell, C. R., 321-323

Cockerell's Building, 332

Coe Fen, 140

Coe Fen Lane, 19

Col de la Faucille, 155

Cole, Alfred, 212

Coleridge, S. T., quoted, 32

Collège de Navarre, Library of, 157

Comédie Française, 108, 232; plays and players of, described, 234-237, $244,248-251$; description of the theatre after the fire, 251, 252

Commencement Sunday, 44

Commissioners for Inquiring into State of the University of Cambridge, Report of, 1852, 84

Concise Guide to Ely Cathedral, 182

Concise Guide to the Town and University of Cambridge, 163

Congrégation de la Sainte Croix, 169

Constantinople, 177-181

Cooke, A. H., 278, 288, 292

Cookesley, Mr., 74

Cookson, H. W., 294, 326

Cooper, C. H., his Memorials quoted, 82

Cooper, John, 84-86

Coquelin, 234, 245, 246, 251

Corby, A., 293

"Cormorants," 46

Corn Exchange, Camb., 299, and note, 316

Corn Exchange St., 4, 82, 300, 302, $307,308,310,330,336$

Corporation of Cambridge, 299, 310

Corpus Christi College, 15, 20, 299, 310

Corrie, G. E., 38

Cory, William (formerly W. Johnson), 54 ; as a master at Eton, 55-57, 68 ; 70,$72 ;$ description of, 72,73 ; writes to Dr. Clark on J.'s progress at Eton, 73-75

Coulevain, Pierre de, 189

Country Life, 184, 188 note

County Courts, 303 
County School, 151

Crawford, Oswald J. F., 69, and note Croizette, Mlle., 234, 244

Cromer, 126, 144

Crotch, G. R., 261, 270, 273, 274

Cuffe, Hamilton. See Desart, Lord

Cuinet, P., 154, 155

Cumming, Isabella, 67

Cumming, J., 60

Cust, Lionel, 151 ; at Paris with J., 162 ; writes to J. about the proposed history of Windsor Castle, $171,172,174$; his reminiscences of J., 219-227

Cyrano de Bergérac, 245, 246

Czar und Zinimerman, 89

DALbY, W. E., 285

Dalton, J. N., 172-174

Damon, Dr., 287

Dandolo, 179

Danicheff, Les, 243, 244, 253

Darling, James, 7

Darwin, Charles, 72 note; centenary of, 204; his collection of fishes made during voyage of the Beagle, $259,265,266,269$

Darwin, Sir Francis, 304

Davidson, R. T., Archbishop, 172, 173

Davos, 166

Dawkins, Professor Boyd, 105

Day, Alfred George, 108, 109

Death, Messrs., 28

De Bunsen, 171

Delafont's sale, 263

Delaunay, 129, 234, 236, 244, 245

Delicate Ground, 131, 132

De Morgan, A., 39, 40, and note, 41

Denmark, 56

Dent, 144

Desart, Lady, 64

Desart, Lord, an appreciation of J., 103, 104

Devonshire, 110

Devonshire, Spencer Compton Cavendish, eighth Duke of, installation of, 1892,149 ; 338 ; raises money for the School of Agriculture, 339

Devonshire, Victor Christian William, ninth Duke of, 339

Devonshire, William Cavendish, seventh Duke of, 305

Dew-Smith, A. G., 307

Dickens, C., 25

Dijon, 156

Doctors' Gallery, 100

Dohrn, A. , 282, 283
D'Orsay, A. comte, 25

Downing College, 59, 64

Downing Site, 311, 328, 331, 334, 340,342

Downing Street, 4, 300, 302, 336

Downing Terrace, 19, 58

Drake, C. F. Tyrwhitt, 267, 269

Drapers' Company, 339, 342

Drosier, W. H., 262

Duc Job, Le, 107

Duffield, Mrs., 67

Dumaine, 234

Dumas, 244

Dunning, J. W., 90

Durnford, R., 226

Durnford, W., 130, 226

EAst India Company, 1

Eastern Counties, County Councils of, 338

Ecclesiologist, 95 note

Eden, F., 186

Edinburgh, 1

Edward VII, King, 96, and note; presides at twenty-fifth anniversary dinner of the A.D.C., 130 ; the proposed architectural history of Windsor Castle, 171-174 ; Coronation of, 176 ; visits Cambridge to open Science Schools and Squire Law Library, 182, 334; 208; his regard for J., 226, 276

Edwards, H. J., 177, 184

Ehrle, Father, 166, and note, 168, 202

Electra, 250

Elliot, W., 239

Ellis, Rev. J. H., 204, and note

Ely Cathedral, 95

Endowments of the Univcrsity of Cambridge, 182, 311

Engineering, Department of, 299, 304, 306,312 ; first Tripos in, held 1894 , 318; Hopkinson Memorial Wing opened 1900,$319 ; 320$. See also Mechanism, Department of.

Enkhuizen, 153

Esher, Lord, 204

Este, Isabella d', 150

Ethnology, Museum of, 340, 341 ; Reader in, 337

Eton, 6, 52; J. at, 54-75; War Memorial Buildings at, 227

Eumenides, 138, 225

Ewbank, L., 267

Ewing, Sir J. A., 151, 317, 319

Examination Rooms, 300, 310, 342

Eyemouth, 65 


\section{Index}

"FALCON" Inn, 20

Falconhurst, 170

Falstaff, 241

"Family," the, 47, 140

Farish, W., 10

Faroe Islands, 95

Fasciculus Joanni Willis Clark Dicatus, 130,204

Faust, 105

Favart, Mlle., 234, 244

Fawcett, Prof. H., 90

Fawcett, W. M., 261, 275, 280, 307, $310,314-316,336,342$

Fayrer, Sir J., 280

Febvre, 234

Fechter, 249

Feilden, Col. H. W., 105, 283, 289

Félix, Dinah, 234

Félix, Rachel, see Rachel.

Festus, 30

Feuillet, O., 241

Figaro, the, 128

Financial Board, 151

Fisher, Dr., 59, 63

Fitzroy, Capt., 259

Fitzwilliam, Lord, 97

Fitzwilliam M useum, 19, 82, 139

Fletcher, H., 205

Florence, 3, 106, 107, 201

Flower, Sir Wm., 104, 277

Forestry, Department of, 340

Fossa Nuova, 168

Foster, Sir M., 115; his help to F. Balfour, 136, 137; 138; his death, 191 ; lectures, 210 ; 223,281 ; request for proper provision for teaching Comparative Anatomy and Physiology, 306 ; 311, 315

Fox, Mrs. Maxwell, 127, 131

France, J.'s visits to, 1842,$15 ; 1857$, $90 ; 1858-9,94 ; 1882,135 ; 1894$, $153-158 ; 1896,161$

France, Anatole, 154, 187, 188, 198

France, Francis, 91

Francesca, Piero della, 202

Francis, Mrs. C., 67

Franciscans, 23

Franklin, M., 169

Frati, Signor, 186

Free School Lane, "Manor House" in, 298; "Great House" in, 299, 300,$305 ; 309,313$

Frere, Mr., of Cottenham, 67

Frere, Wm., Master of Downing, 18

Funchal, 148
Gadow, H., elected Strickland Curator, 281; his work on the Bird Collection, 283, 284 ; 286 ; records death of Mrs. Strickland, 288; 292

Galton, Francis, 95

Gaol, at Cambridge, 82

Garraud, 234

Gas Company, Cambridge, 14 note

Gaskell, C. G. Milnes, 169

Gaskell, Lady C. Milnes, 170, and note

Gedge, Joseph, 267

Geneva, Lake of, 153,155

Geoffrin, Mme., 195

Geology, Museum of, Dr. Woodward's collection housed in the present Novel Room, 1735,320 ; room required, 1818, ib.; Syndicates (1-10) on the proposed Woodwardian Museum, 1821-37, 320-323 ; build. ing commenced 1837,323 ; finished $1842, i b$. ; statement of Professor Sedgwick, 1871, 324-326 ; his death, 1873,326 ; proposal to build Sedgwick Museum as memorial to him, 1874, 327 ; Syndicates (11-22) on it, 1874-99, 327-332; building completed 1904, 332

George III, King, 7, and note, 8-10

George IV, King, 8

George V, King, 208

Gergovie, 187

Germany, J. visits, 87-89, 99

Gervais, Prof., 105

Giffard, Sir Geo., 118

Gilbey, Sir W., 338

Giotto, 94

Girls' Friendly Society, 13, 200

Gladstone, Robert, 69 , and note

Gladstone, Rt. Hon. W. E., 213

Gloucester, Duke of, 90, 91

Gluck's Orpheus, 213

Godman, F. Du Cane, 105, 289

Godolphin, Lord, 58, 64

Gogmagogs, the, 28

Goldsmith, O., 241

Goldsmitbs' Company, 332, 340

Goldsmiths' Reader in Metallurgy, 340

Golgotha, 100

Gonville and Caius College, 81, 262, 313

Goodacre, F. B., 264

Gordon, Sir Arthur, see Stanmore, Lord

Gordon, Cosmo, 198, 199

Got, Ed., 234, 250, 251 
Gozzoli, Benozzo, 203

Grant, C. E. , 149

Grantchester, 28

Gravel Pit Close, 19

Gray, Chas., Rector of West Retford, $84,101,102$

Gray, Capt., of Peterhead, 279

"Great House," the, in Free School Lane, 299, 300, 305

Greek Plays, 138

Greenwood, Robert Hodgson, 37, 38

Griffiths, J., 335

Grove Lodge, 19

Günther, Dr., 104, 125, 265, 266

Guerne, Baron de, 164

Guildford, 153

Guildhall, at Cambridge, 81

Guillemard, F. H. H., 148 note, 283, 284,287

Guiseley, Leeds, 4, 5, 13, 14, 65

Guizot, F. P. G., 43

Gurney, Mr., 286

Guyot, Yves, 182

Gwatkin, H. M., 285

HAAST, Sir J. von, 285

Haddon, A. C., 277, 278

Hague, 'The, 151, 224

Halifax, Lord, 114, 209

Hallam, Arthur, 45

Haly, A., 281

Hamilton, J. F., 274

Hammond, Lemprière, 86

Handel Festival, 213

Harcourt, Vernon, 115

Hardwicke, Lord, 64

Hare, J. C., 100

Harker, A., 330

Harmer, S. F., 149, 284, 285, 291

"Harmonies in Bordeaux," 212

Harrogate, 151

Harrow, 145

Harwood, Sir Busick, 2, 3, 263, 265

Hauxton Gate, 58

Haviland, J., 2, 3, 14 note

Hawks' Club, 257

Hawtrey, Dr., 54, 71, 74

Headly, Messrs., 310

Heape, W., 282, 283, 285

Heath, Francis, 1

Heberden, W., 10

Henry III's Great Hall, 174

Henry IV, 241

Henslow, J. S., 43, 60 note, 137, 258, 259

Hepburn, James, 270, 278

Herbarium, see Botany School
Hereford, 124, 125, 162, 163

Hewitson, Mr., 287

Hexter, Mr., 76

Hills Road, 28

Hills, ' $\Upsilon$. Hyde, 256

Hobhouse, Sir John Cam, 3

Hobson, Thomas, 20; Conduit of, 81

Hoeven, Jan van der, 6

Hofburg Theater, 105

Holland, 151, 152

Holland, Lady, 194, 197

Holden, H. A., goes abroad with J., 76-80

Holmes, R., 172

Hope, Beresford, 115

Hope, H. St. J., 173-175

Hopkinson, Mrs. Evelyn, 319

Hopkinson, John, 319

Hoppett, 102

Horace, 238 note

Hort, F. J. A., 5

Horticultural Show, at Cambridge, 67 ; at London, 71

Horton-Smith, R., 90

Hospital of St. Anthony and St. Eligius, 19

Hôtel des Invalides, 77

Hotham, H. J., 116

Houghton, Lord, 45, 138

How Will it End? 241

Hubbard, G., 342

Hudson, the " Railway King," 43

Hügel, Baron A. von, 139, 194, 195, 341

Huguenots, The, 88

Hughes, T. McK., 144, 326, 327, 329, 332,338

Hullah, J., 52

Humfrey, Charles, 12

Humphry, Sir Geo. Murray, 5, 99; succeeds Prof. Clark as Prof. of Anatomy, 1866, 100; his speech on F. Balfour, quoted, 137 ; 265 ; presents a skeleton of a sea otter to the Mus. of Znol., $269 ; 275,281,315$

Humphry, Lady, 337

Humphry Museum, see Medical School

Huxley, T. H., 137, 270 note

IBSEN, H., 106

Iceland, 95

Impington, Experimental Farm at, 339

Inclosure Acts, 28

Innes, H. McL., 203

Ion, 138, 225

Ionica, by W. Cory, 55, and note

Iphigenia in Tauris, 225 


\section{Index}

Irish Plays, 247

Irving, Sir H., 238, 252

Italy, 94, 96, 166

JAcksoN, Henry, 103; his travels abroad with J., 105-109; 145, 223

Jackson, Ricbard, 10, 300

Jackson, Sir T. G., 330, 331, 335, 341, 342

Jacksonian Professor, rooms used by, 297, 300, 301, 303, 304, 308, 313

Jebb, Sir R., 223

Jenkinson, F. J. H., 276

Jenyns, L., Museum of Zoology described by, 258-261

Jessopp, A., 143

Jesus College, 38, 82

John Milton, 106

Johnson, William, see Cory, William

Jones, Lawrence, 220, 221

Jones, T. Percy, see Aytoun, W. E.

Jordan, Messrs., 28

Jouassain, Mme., 234

Jougue, 154, 155

Jura Mountains, 155

Justinian, 181

KANTHACK, A. A., 335

Kean, Chas., 238

Keeping, Henry, 325

Kent, W. Savile, 267

Kew, 9

King Lear, 9

King's College, court opened in 1825 , 20 ; grove of elms at, $21 ; 141$; lawn of, 206

- Chapel, 14, 184, 300

- Old Court, 82, 321

King's Ditch, 20, 300

King's Hall, 23, 141, 142

King's Parade, 25, 214

Kingsley, Charles, 96

Kitchener, Lord, 164

Kitling, Dr., 58

LABYRINTH, the, 81

Lacressonière, 234

Lafontaine, 234

Lafreri, 202

Lagrange, J. L., 40

Lake District, 98

Laleham, 142

Lane, E., 293

Langley, J. N., 212

Lankester, Sir E. Ray, 137

Laon, 161

Laroche, 234, 242
Latham, H., 332, 334

Laurent, G., 157, 158

Law School and Library Buildings Syndicate, 331

Lawley, A., 239, 240

Lawrence, Sir A. W., 148

Lawrence, Lady, 148

Leadbeater, Mr., 259

Leathes, S., 150, 151

Leckenby, Mr., of Scarborough, 325, 326

Lecture Rooms, New, 342, 343

Léguat, Fr., 268

Lensfield Rd., 28

Le Puy, 135, 185

L'Espinasse, Julie de, 193-195

Lesson for Life, A, 234

Lesueur, 234

Lewis, W. J., 329

Liber Memorandorum Ecclesie de Bernewelle, 187, 188, 192

Libraries, papers and lectures by J. on, $153,158,163$

Library Association, 184

Lightfoot, J. B., 86

Lincoln Cathedral, 153

Lion Hotel, Cambridge, 29

Lister, J. J., 291

Liveing, G. D., 5, 294, 312, 313, 339

Liversidge, Prof., of Sydney, 283

Locke, J., 39, 40

Loggan's Cantabrigia Illustrata, 184

London Assurance, 253

London Road, the, 19

Louis XIV., 42

Love Lane, see Coe Fen Lane

Lowe, R. T., 259, 264, 266

Lowndean Professor, rooms for, 303, 343

Lowther, Rt. Hon. J. W., 239, 240

Luard, H. R., 93 ; undertakes the removal of the "Doctors' Gallery," 100, 126, 127; memorial to, 150 ; 223,224

Lucasian Professor, rooms for, 303, 343

Lucrezia Borgia, 88, 89, 105

Lütken, Prof., of Copenhagen, 267

Lycée Henri Quatre, 157, 158

Lydekker, R., 72 note, 276

Lynn, 22

Lyon, Mr., 312

Lyons Mail, The, 238

Lyttelton, Rt. Hon. Alfred, 126, 204, 219

Lyttelton, Hon. Edward, 219

Lyttelton, Lady, 162 


\section{$35^{6}$}

MaCALISTER, A., 314, 315

MacAndrew, Robert, 272, 285

Macartney, Dr., 264, 265

Macaulay, Lord, 206

Macfarlane-Grieve, W. A., 339

Macmillan \& Co., 81, 149

Macmillan's Magazine, quoted, 3, and note

Madeira, 148, 149, 173

Madingley, 23

Madingley Hall, 96

Magdalene Bridge, 83

Magdalene College, 95, 192

Mahmoud, Sultan, the Conqueror, 180,181

Maine, Sir H. J. S., 67

Maitland, F. W., 191, 192

Mansel, W. L., 17

Marciana Library, 186, 201

Margaret's, Lady, Statutes, 84

Marie Antoinette, 77

Marie Stuart, 105

Market Hill, 80, 81

Marlow, 72

Marr, J. E., 260 note, 330

Marsh, Prof., of the U.S., 105

Marshall, A. M., 120, 274

Marshall, Wm., 342

Martin, F., 84

Martin, Henri, 169

Martin, T., M.A., 299

Mary, Queen of England, 84

Mason, A. J., 162, 204

Mathematical Tripos, 39, 305

Mathematics, Professor of, rooms of the, 297, 304

Mathews, Chas., 247, 253

Mathison, W. C., 86

Matrimonio Segreto, $\mathrm{Il}, 107$

Maubant, 234, 242

Maudslay, A. P., 139, 340, 341

Maxwell, J, C., 137, 305

Mayor, J. E. B., 145

Mechanism, Department of, 308, 309, 310, 317,318. See also Engineering, Department of

Meckel, Prof., of Halle, 263

Medical School, 82, 300, 306, 314, 327, 333,335 ; syndicate appointed to consider erection of new buildings, 1899, 336 ; recommend buildthe Humphry Museum, $i b . ;$ opened by King Edward VII 1904, 337

Mellish, Agnes, 132

Mellish, Edward, 114

Mellish, Sir George, 118

Melbourne, Lord, 4
Metallurgical laboratory, 340 ; Goldsmiths' Reader in Metallurgy endowed 1908, $i b$.

" Michael's Mount," 192

Middleton, T. H., 339

Midsummer Common, 83

Milan, 201

Milbanke, Miss, 2

Mill Lane, 20, 336, 342

Miller, W. H., 206

Milman, Sir Archibald, 169

Milman, Lilian. See Clark, Lilian (Mrs. Edward)

Milne-Edwards, Professor, 105, 129, 164

Milner-Gibson, G. G., 132

Milnes, R., 239

Milsom, J. B., 263

Milton, Lord, 95-97

Milton Road, 337

Mineralogy, Department of, Professorship established in 1808, 302 ; rooms for, 303,304 ; roof of the Mineralogical Museum raised, 1884, $312 ; 319,323,333$

Mitchell, Arnold, 339

Molière, 234, 245

Monaco, 108

Mont Blanc, 77, 155

Mont Dore, 184

Moore, Thomas, 3

Moral Sciences Tripos, 41

More, Hannah, 8

Morgan, J. P., 18

Morgan, John, of London, 258

Morgann, Maurice, 241 note

Moro, Antonio, 84

Morphology, Department of, 297, 319, 343

Morris, Professor, 325

Mortlock Site, the, 299, 300, 305, 310, 311,342

Moulins, 198, 199

Mounet, Paul, 246, 248

Mounet-Sully, J., 234, 237 ; as Gérald in La Fille de Roland, 242; Ruy Blas, 242, 243 ; 246 ; Othello, 248 ; Edipus, 249 ; François Ier in Le Roi s'Amuse, 250

Murie, James, 267

Museum and Lecture Rooms Syndicate, instituted in 1866, 294 ; its first members, $i b ., 295,296$; J. becomes Secretary to, 1880, 297 ; is formally appointed by the Senate, 1883 , ib. ; resigns the Secretaryship, 1891, 316; their appreciation 


\section{Index}

of his services, 316, 317 ; Syndicate abolished, 1912, 317

Museums of Science, history of, 298343. See also Museums of the several Departments

Musset, A. de, 244, 247, 253

Myers, C. S., 342

Mytton, Captain D. H., 69, and note

NAPLES, Bay of, 282

Napoleon I, Emperor, 29, 45, 193

Napoleon III, Emperor, 110, 189

Natural Sciences Tripos, 5, 41, 303

Neville, Archdeacon, 144

New Theatre, Cambridge, 256

Newall-Martin, 307

Newcastle, Thomas Holles, Duke of, 41

Newcastle-upon-Tyne, 1, 2

Newnham, 310, 341

Newton, Alfred, appointed Professor of Zoology, 5, 100 ; letter on J.'s engagement to Miss Buchanan, 114-116; two characteristic letters of, 118-120 ; moves resolution on memorial to $\mathrm{F}$. Balfour, 137, 138; 159 ; his death, $192 ; 206,266$; urges appointment of a Curator in Zoology, 272 ; nominates T. W. Bridge, 273 ; his rooms in Fawcett's Building, $275 ; 281,282$; gives collection of birds to Museum, $286 ; 287,292$, 307

Newton, C. M. , 150, 219, 239

Newton, Sir Edward, 267, 268

Newton, H. A., 165, 166, 241

Newton, Sir Isaac, 39,40

Newton Library, 269, 343

Nice, 56

Nice Firm, A, 239

Nobel Prize, 305

Norman Library, 269, 343

Normandy, 104

"Norton Garth," 191

Norway, 90

Norwich, 144

Notorious Mrs. Ebbsmith, The, 254

Nôtre Dame, 87, 88

Noyon, 161

Nürnberg, 189

Ober-Ammergau Passion Play, 129, 220

Observatory, Cambridge, 27

O'Connor, John, 132, 233, 234

Octagon, the, second home of Human Anatomy, 297, 302, 314, 315, 329 ; afterwards used for the teaching of

Surgery and Obstetrics, \&c., 335

Edipe Roi, 246, 249

Edipus Tyrannus, 138, 249

Okes, R., 21, 63 note

Okes, Mrs., 63, 69

On ne badine pas avec l'Amour, 244, 245

Opéra Comique, 232

Optical Lecture Room, 343

Orcival, 184

Orvieto, 167

Osborn, H. F., 277

Ospedale di Santo Spirito, 167

Othello, 107, 248, 249

Owen, Sir Richard, 158, 263

Oxford Historical Society, 139

PAGET, Sir G. E., 60 note, 294, 335

Pall Mall Gazette, 133

Palmer, E. H., 138, 269

Paris, J. at, 1852, 76, 77 ; 1853, 87; 1867,$104 ; 1868,108-110$; 1873 , 116 ; $1879,127-129$; 1893, 150 ; $1894,151,152 ; 1895,157,158$; 1897, 162; 1901, 169; 1902, 177 ; 1906,$185 ; 1907,193 ; 1909,201$

Paris Exhibition, 127, 128

Paris Mail, J.'s unpleasart experience in the, 133-134

Parker, E. H., 298

Parker's Piece, 58, 62, 82

Parma, 106

Parry, John, 67

Parson's Court, 310

Parthenon, the, 181

Pathology, Dept. of, 82, 297, 314, 335 ; see also Medical School

$\mathrm{Pau}, 116$

Peacock, George, 37, 38, 322

Peile, John, 147

Pemberton, Francis, 53

Pemberton, Col., 53

Pemberton, Mrs., 52, 53

Pembroke College, 82, 151, 310

Pembroke Street, 20, 300, 313

Pepys, S., 20

Perez, F., 289

Perne, A., 188

Perrier, E., 105, 204

Perry, C., Bp. of Melbourne, 37

Perse Almshouses, 299, 300, 301, 310, 313, 328

Perse School, Old, 299, 310, 329 ; Headmaster's House, 306

Peterhouse, 19

Petty Cury, 20 


\section{8}

Pevensey Whale, the, 265, 285

Phear, Sir John, 280, 281

Phear, S. G., 294

Philibert II, 156

Philip II, King of Spain, 84

Philosophical Society (Camb.), see Cambridge Philosophical Society

Philpott, Mrs., 62

Physics, see Cavendish Laboratory

Physiology, Department of, 299, 306, 307,308 ; room required for extension of Laboratory, 1889, 315; the new rooms completed, 1891, 316 ; 337 ; new Laboratory in course of construction, 340,342

Pike, Wm. Bennett, 183

Pitt Press, see University Press

Platt, F. T., 90

Plumian Professor, rooms for, 303, 343

Poitiers, 127

Pollock, Walter, On J.'s love of the theatre (Chapter XI.), 231-2506

Pontgibaud, 194, 195

Popple, Mr., 2

Powell, David, 96, 104

Powell, Henry, 96, 104, 121 note

Powell, L. M., 219

Power, John, 99, 294

Praed, W. M., 45

Prest, Mrs., 59

Preston, 163

\section{Pribylov Islands, 276}

Prince of Wales's Theatre, 246

Prior, E. S., 336

Prior, Joseph, 105, 108, 219

Probyn, Sir Dighton, 174

Procter, Joseph, 24

Proctors, 142

Prothero, G. W., 171, and note, 212

Pryme, G., 24

Pryme, Mrs., 90

Pryor, F. R., 225

Pryor, Marlborough, 209

Psycho-Physics Laboratory, 340, 341, 342

Pump Lane, 80

QUnen Anne's Terrace, 82

Queens' College, 4, 163, 301

Queens' Lane, 302

RACHEL, 250, 252

Ray, John, 60 note

Ray, Dr., of America, 8 note

Ray Club, the, 47, 60, and note, 67
Rayleigh, Lord, 305, and note

Reade, Charles, 238

Rede Lecture, 152, 153

Redfern, W. B., 256

Redfern, Mr., Architect, 314

Reed, Mr., 52

Reform Bill, 24

Registry, fire at the, 1893,151

Reichemberg, Mlle., 234, 237

Reubell, Etta, 150, 189

Reubell, J., 128, 150, 169, 251

Rheims, 161

Rhine, the, 76, 80

Rhine Provinces, 15

Rickman and Hutchinson, Messrs., 322

Riot Act, 4

Rivers, W. H. R., 342

Riviera, the, 110

Roberts, H. A., 298

Roberts, T., 330

Robertson, T. W., 246

Robinson, J. A., D.D., 193

Robinson, Walter, 293

Roderick, Dr., 13

Roi s'Amuse, Le, 250, 251

Rolleston, Prof., 104, 268

Roman Catholic Church, Cambridge, 13

Rome, 107, 166-168

Romilly, J., 217

Rose Crescent, 16

Rosebery, Lord, 198

Rothenstein, C., 150

Rouen, 157

Roxburgh, 1

Roy, C. S. , 314

Royal College of Surgeons, 271, 277

Royal Society, 5

Royat-les-Bains, J. at, 1905,184 ; 1906, 186-188; 1907-8, 192-198; 1909, 205, 206

Royer, Mlle., 234

Ruskin, John, 30

Russell, Lady C., 287

Russell, C. H., 287

Ruy Blas, 240, 242, 243

ST. ANDREWs, 1

St. Andrew's Hall, Camb., 256

St. Andrew's Hill, 300

St. Augustine, Priory of, 82

St. Bene't's Church, 13, 299 ; parish, 82

St. Botolph's Church, 20, 124

St. Catharine's College, 20, 21, 62, 64, 301 


\section{Index}

St. Edward's Church, 81 ; parish, 82 , 310

St. John's College, 14, 21, 83, 141 ; chapel, 81

St. John's Lane, 81

St. John's Street, 81

St. Mark's, Venice, 186, 222

St. Mary's the Great, Church, 20, 26, 81,100

St. Mary's the Less, Church, 113

St. Paul's Cathedral, 153

St. Peter's Rome, 168

St. Tibbs' Row, 336

Salvin, A., 82, 261, 297, 304, 307, 333, 337,342

Salvin, Osbert, 104, 268, 273, 275, 280,281

Salvini, 106, 248, 249

Salvucci family, 203

Sand, George, 252

Sandars Lectures, 153

Santa Sophia, 179, 180, 181

Sarcey, 127

Saturday Review, 127

Saxe-Meiningen Company, 225

Sayle, C. E., 162, 188, 189, 191

Scarborough, 158

Schlumberger, M., 164

Schönbrunn, 117

School for Scandal, 131

Schröder van der Kolk, Prof., 265

Scientific Instrument Co., Camb., 336

Sclater, P. L., 105, 268

Scotland, 65

Scott, W. B., 277

Scroope House, 12 ; built in 1837, 14 ; Sunday evenings at, 112 ; J. and family move to, 1885, 140; enlarged, 190

Sedbergh, 144

Sedgwick, Adam, Prof. of Geology, $2,6,22,43,57,64$; his funeral described, 115, 116; his Life published, 144, 145; 302; statement to the Univ. on the Geological Museum and the Leckenby Collection, 324-6 ; memorial to, 326, 327

Sedgwick, Adam, Prof. of Zoology, his sorrow on the death of $F$. Balfour, 136, 137; carries on Balfour's work, $282 ; 312 ; 329$

Sedgwick, Miss, 144

Sedgwick Museum, see Geology, Museum of

Seeley, Sir J. R., 90
Ségur, Marquis de, 193, 195

Ségur, Vicomte de, 193

Selby, P. J., 268

Senate House, 3, 22, 41, 64

Senate House Hill, 20, 21

Senlis, 161

Sévigné, Mme. de, 155, 189

Seward, A. C., 204

Seymour Court, 73

Shakespeare, William, 32, 87

Sharp, David, 288, 292

Sharp, R. B., 268

Shaw, W. N., 151

Shelford, 192

Shelford Common, 58

Sheridan, R. B., 9, 34, 241

Shirehouse, at Cambridge, 82

Shore, Teignmouth, 99

Sidgwick, Henry, 315, 316

Sidmouth, 191

Sidney Sussex College, 21, 313

Siena, 167, 203

Silvain, Mme., 250

Simeonites, 81

Simpson, Palgrave, 232

Sixtus IV., 167

Slaughter House Lane, 82

Smith, Alexander, 30

Smith, Professor Henry, 137

Smith, Sir Henry Babington, 177

Smith, W. Robertson, 223

Snow (later Kynaston), 90

"Society for the Prevention of Cruelty to Undergraduates," 36

Somerset, Charles Seymour, Duke of, 301

Somerville, W., 339

Sophora chinensis, 82

Sorbonne, library at the, 152

Sothern, 233

" Spital End," 19

Squire, Rebecca F., 334

Squire Law Library, 182, 333, 334, 335

Staël, Mme. de, 196, 197

Stamboul, 180

Stanford, Sir C. V., 213

Stanley, A. P., 115, 173

Stanley, Mgr., 167

Stanmore, Lord, 139, and note.

Statutes of the University, 84

Steenstrup, 56

Steinmann, Professor, 168

Steller's "Sea-Cow," 139, 286

Stephen, J. K., 225

Stephen, Sir James, 42

Stephens, the entomologist, 259 
Stevenson, J. J., 313

Stewart Collections of skulls, 288

Stokes, Sir G. G., 165, 294

Strickland, Mrs. C. D. M., 266, 268, $273,285,288,293$

Strickland, Frances, 273

Strickland, H. E., $266^{\circ}$

Strickland Collection, 273, 280, 288

Strickland Curatorship, 273

Strickland Library, 269, 274

Stuart, James, 85, and note, 308, 309, $312,318,319$

Stubbings, William, 115, 276, 277, 283,293

Studd, P., 150

Sutherland, Duchess of, 64

Sutton, Ven. Robert, 71 , and note, 88

Swainson, William, 264

Swainson Collection, 266, 268

Switzerland, 77-80, 96

Sykes, Sir Mark M., 3

TABOR, Montagu, 108

Taillade, 251

Tainter's Yard, 300

Talbot, Eustace, 170, 183, 192

Talbot, J. G., 170

Talbot, the actor, 234

Talleyrand, 194, 197

Talma, the actor, 197

Tatham, G. B., 130, 201, 203

Taylor, Sedley, 101, and note

Taylor, Tom, 86, 234

Tedaldi, L., 202

Tennis Court Road, 328

Tennyson, Alfred, Lord, 45, 222

Thackeray, W. M., 24, 32, 45, 232

Thames, the, 226

Theatre Coffee-House, 81

Théâtre Français, see Comédie Fran. çaise

Theodosius, Emperor, 181

Thirlwall, Connop, 35, 138

Thiron, 234

Thompson, W. H., 32, 37, 38, 89

"Three Cups" Inn, 310

Threlfall, R., 282

Tissot, 109

Tom Thumb, General, 15, 16

Torquato Tasso, 105

Transit of Venus Expedition, 275

Tresse, Mme., 128

Trinity College, 16, 21 ; J. entered at, 1852, 83; Queen Mary's portrait presented to, by J., 84 ; J. elected a scholar of, 89 ; receives a Fellowship, 91 ; agitation to alter dinner hour at, 98 ; bust of Prof. Clark presented to, $138 ; 141,165$

Trinity College : Chapel, 21

- Combination Room, 101 note, 102

- Conclusion Book, 36

- Great Gate, 124

- Hall, 22, 29, 30, 101, 102

- "Iniquity Corner," 38

- Library, 22, 102

- Lodge, 64

- Muniment Room, 101

Trinity Hall, 81, 82

Trinity Street, 16, 21

Trotter, Coutts, 139, 279, 305

Trumpington, 59

Trumpington Gate, 20

Trumpington $\mathrm{Hall}, 53$

Trumpington Road, 28

Trumpington Street, 13, 18

Twiss, Mr., 58

Tyrol, the, 220

\section{UMBRIA, 107}

Union Society, 31

University Arms Hotel, 58

University Library, 81, 82; Syndicate propose roofing in of Eastern Court, 175; appeal for funds for, 183,184 ; allowed to deposit duplicates in New Museums, 269; Geo$\operatorname{logy}$ and Mineralogy housed in the Novel Room of, 302, 320; Lord Rayleigh gives part of the Nobel Prize to, 305 note; Cockerell's Building completed, 323,$324 ; 331,332$, 333

University Press, 20, 173, 301

VACHELL, C., 259, 266

Vatican, the, 167

Vaughan, Sir Chas., 114

Veit family, 220

Venice, 105, 106, 185, 186, 201, 221, 222

Ventnor, 208

Vercingetorix, 187

Verona, 222

Vesuvius, Mount, 94, 95

Vezelay, 153, 156

Vichy, 189

Victoria, Queen, 51 ; visits Cambridge, 62-64 ; Eton, 70, 71; 149, 172, 173, 174

Victoria, Princess, 182, 332

Vidal, F., 57

Vienna, 105, 116, 117 
Vines, S. H., 312

Viollet-le-Duc, 156

Virgil, 107

Vivian, Lt.-Col. Sir A. P., 69, and note

Vokes, Rosina, 125

Voltaire, 196, 252

Volunteer Movement of 1859, 25

WAGNER's Ring, 188, 213, 225

Waldstein, Sir C., 225

Wales, 98

Walker, Richard, 297; purchases Manor House in Free School Lane as site for Botanic Garden, 1760, 298; "Great House" used as lecture room for botany, 299 ; disposal of his garden, $1853,303,333$; 305,337

Wallop, Hon. J., 130

Walters, Mr., 14

Wanstead House, 13, 14

Warburton, C.. 288

Ward, J. M., 69 , and note

Warren, R., 9

Warwick Street, 80

Washington, National Museum of, $283,286,287$

Wasps, 138

Water Company, Camb., 23, 81

Waterhouse, A., 82

Watson, C. K., 2, 3 note, 158, and note

Watson, R., 39

Webb, W., 323

Weldon, W. F. R., 282

Welldon, J. E. C.. 219

Wells, 153

Welton, Yorks, 2

Wenlock Abbey, 169, 170

Wentworth, 95

Westminster Abbey, 71, 153, 176, 193

Whewell, Wm., 18, 22, 26, 27 ; nicknamed "Whistle," 37,$38 ; 41$; and Professors' Lectures, 42, 43; helps to extinguish fire at Trin. Hall, 81, 82 ; and Trinity Fellowships, 91 ; $137,138,321,322$

Whitgift Almshouses, 175

Whittlesea Mere, 19

Whittlesea Yeomanry, 64

Wilderness, the, 83

Williams, Mrs., 59

Williamson, Prof., 137

Willis, Francis (1718-1807), 7-10

Willis, John, Vicar of Lincoln Cathedral, 7
Willis, John (son of Fr. Willis), 8, 10

Willis, Mary (daughter of R. D. Willis), see Clark, Mary (J.'s mother)

Willis, Robert (1800-1875), his life and work, 10, 11, 12; his death, $124 ; 271,304$

Willis, Robert Darling (1760-1831), 10

Wilmot, J. P., 287

Windsor Castle, 171-174

Wilson, Sir H. F., 146; his reminiscences of J., 201-203; 208, 225

Wise, Charley, 57

Woking, 186

Women's Degrees, 159-161

Wonfer, 44

Wood, Mrs. John, 252

"Wooden Spoon," 204

Woodham, H. A., 206

Woodhead, G. Sims, 335

Woodhouse, R., 2, 3

Woodward, John, 320, 324

Woodward, S. P., 267, 278

Woodwardian Museum, see Geology, Museum of

Wordsworth, Wm., 64 note

Woring, Mr., 52

Working Men's College, 163

Worms, the actor, 234

Wraxall's Posthumous Memoirs, quoted, 8 , and note

"Wrestlers" Inn, 21

Wycliffe, J., 175

Wymeswold, Leics., 4

Wynne, Mrs., 148

XeNophON, 80

YARRELL, Mr., 259

Yorkshire, 144

Yriarte, Charles, 150

ZooloGY, International Congress of, 164

Zoology and Comparative Anatomy, Museum of. (See also Anatomy, Comparative, Museum of)

Curatorship of Zoology established, 1877,275 ; J. F. Bullar first Curator, $i b$.

collection of Indian mammals presented by $R$. Lydekker, 276

- sealskins presented by the Alaska Commercial Co., $i b$.

Mr. Bullar resigns the office of Curator, 1878, 276; succeeded by F. J. H. Jenkinson, ib. 
Zoology and Comp. Anat. (contd.)

alteration to building completed, $1879,276,308$

skeleton of a red deer presented by W. Stubbings, 277

A. C. Haddon appointed Curator, $i b$. skeleton of a crocodile presented by Royal Coll. of Surgeons, $i b$.

Bison bonasus presented by Emp. of Russia, $i b$.

A. C. Haddon resigns the Curatorship, 1880, 278; succeeded by Rev. A. H. Cooke, ib.

Philosophical Society's library removed to, $1881, i b$.

fire in the spirit room, 279

skeleton of seals and Polar bear presented by Capt. Gray of Peterhead, $i b$.

skeletons of Indian elephants presented by Sir J. Phear and Sir J. Fayrer, 280

catalogue of the Strickland Collection finished, $i b$.

Mr. Balfour appointed Prof. of Animal Morphology, 1882, $i b$.

laboratory for Animal Morphology built, 311

Mr. Salvin resigns the Strickland Curatorship, 1883, 281; succeeded by Dr. H. Gadow, $i b$.

Balfour Library presented, 282

Brady Collection of Foraminifera presented, 1883, $i b$.

Dohrn Collection of Invertebrata purchased, 282, 283

specimen of an African elephant presented by W. Heape, 1884, 283

collection of birds from Natal presented by Major Feilden, $i b$.

Birds of Paradise presented by Dr. Guillemard, 1885, 284

catalogue of the exhibited portion of the Invertebrata begun, 1886, $i b$.

Mr. Brady arranges his collection of Foraminifera, 1886-7, $i b$.
Zoology and Comp. Anat. (contd.) collection of amphibia and reptiles from Portugal presented by Dr. Gadow, 284, 285

series of bones of the Moa (Dinornis) presented by Sir J. von Haast, 285

Curator reports on the MacAndrew Collection, $i b$.

collection of birds belonging to Sir W. Jardine acquired, 285,286

specimens of birds presented by Prof. Newton, 286

Steller's "Sea-Cow" (Rhytina gigas) received from the U.S. Nat. Mus. at Washington, 1887, 286, 287

collection of British birds' eggs presented by Lady C. Russell, 1888, 287

series of British spiders presented by Mr. Warburton, 288

Mr. Cooke resigns the Curatorship of the MacAndrew Collection, $1889, i b . ;$ succeeded by Dr. D. Sharp, $i b$.

special room set apart for an Entomological Dept., $i b$.

Stewart Collections of skulls and horns exhibited, $i b$.

skeleton of the Jamaica seal (Monachus tropicalis) presented by Dr. F. Du Cane Godman, 289

Strickland Curator's report on the value of the osteological collection, $i b$.

invertebrate collection increased by the remainder of Mr. Brady's col. lections, 1890, $i b$.

collection of birds from Barbados presented by Col. Feilden, 289, 290

J. resigns the Superintendentship, 1891, 290, 291; succeeded by Dr. S. F. Harmer, 291 ; his appreciation of J.'s work, $i b$.

Zutphen, library at, 152, 153, 224 


\section{Biography and Reminiscence.}

\section{Sixty Years in the Wilderness :}

More Passages by the Way.

By Sir HENRY LUCY (Toby, M.P., of 'Punch'), Author of 'A Diary of Two Parliaments,' 'Sixty Years in the Wilderness,' \&c. With a Frontispiece. Demy 8vo. ros. $6 d$. net.

Pall Mall Gazette. - 'Sir Henry Lucy's reminiscences can be read and re-read, for they are inspired by a perception of the many humours and dramatic turns that present themselves in the political and social world. He is a true artist as distinct from a mere entertainer."

\section{Boswell, the Biographer.}

By GEORGE MALLORY. With a Portrait. Large post 8 vo. 7s. $6 d$. net.

Globe. - The best attempt that we have come across to provide a just estimate of his qualities and character.'

Atheneum.-' Mr. Mallory writes in an entertaining manner about an entertaining subject.'

\section{Scenes and Memories. [Second Impression.}

By WALBURGA LADY PAGET. With a Portrait. Large post 8vo. 7.s. 6 d. net.

Times.- "Lady Paget has rich and varied sources to draw upon for her reminiscences. She gives us silhouette portraits of eminent personages and lively sketches of society in the various capitals.'

What the Judge Saw : being 25 years in Manchester, by one who has done it.

[Third Impression.

By His Honour Judge EDWARD ABBOTT PARRY, Author of 'The Scarlet Herring, and other Stories,' 'Judgments in Vacation,' \&c. Large post 8vo. 7s. 6d. net.

Daily Ckronicle.- 'The book is diverting and well strewn with personalities. "If your Lordship pleases," give us another volume like this. It bespeaks a human man with a good heart as well as a clever head.'

\section{Eton in the Seventies.}

By the Honble. GILBERT COLERIDGE, Author of 'An Instinctive Criminal,' 'Jan Van Elselo,' \&c. With 8 Illustrations. Large post 8 vo. 75 . $6 d$. net.

Standard.-'Mr. Coleridge's book is very amusing, and for those who make their first acquaintance with Eton through its pages it will provide much interesting novelty.'

London: SMITH, ELDER \& CO., 15 Waterloo Place, S.W. 


\section{Travel and Sport.}

\section{The Land that is Desolate. An Account}

of a Tour in Palestine.

[Second Impression.

By Sir FREDERICK TREVES, Bart., G.C.V.O., \&c., Serjeant-Surgeon to H.M. the King. Author of 'The Cradle of the Deep,' 'Uganda for a Holiday,' \&c. With Illustrations from Photographs by the Author and a Map. Small royal 8vo. 9s. net.

Birmingham Daily Post.- 'The author makes every page interesting, for he is a keen observer with keen sense of humour, but the title he gives to the book is well justified.'

Globe.- ' Much of the charm that characterises Sir Frederick Treves' book lies in that ironic humour which every now and then breaks forth in his descriptions of cities and men."

\section{Dawn in Darkest Africa}

By the Rev. JOHN H. HARRIS. With an Introduction by the Rt. Hon. the EARL of Cromer, O.M., P.C., G.C.B. With 40 pages of Illustrations and a Map. Small royal 8vo. 10s. $6 d$. net.

Daily Chronicle.-'Mr. Harris has a warm and generous heart, full of compassionate understanding of the natives. He shares with $\mathrm{Mr}$. Morel the honourable distinction of having roused the conscience of Europe to the enormities practised in the Congo Free State.'

\section{A Home Help in Canada.}

By ELLA C. SYKES, Author of 'Through Persia on a Side Saddle,' 'Persia and its People.' With a Portrait. Large post 8vo. 6s. net.

Church Family Nezuspaper. - A copy of this book should be in every G.F.S. and Y.W:C.A. library, as well as in all schools and village libraries and other societies for the benefit of girls and womea.

\section{On the Track of the Abor.}

By POWELL MILLINGTON, Author of 'To Lhassa at

Last,' 'A Homeward Mail,' \&c. Crown 8vo. 3s. $6 d$. net.

Scotsman.- 'The author had many interesting experiences, and his book gives an excellent idea of the difficulties which confront a military expedition on 2 considerable scale in an unknown country.'

A GIFT FOR NATURALISTS AND SPORTSMEN.

\section{The Grouse in Health and Disease.}

Edited by A. S. LESLIE and Dr. E. A. SHIPLEY (Master of Christ's College, Cambridge). With an Introduction by LORD Lovat. In one Volume. With Coloured and other Illustrations. New and Cheaper Edition. Royal 8vo. 12s. $6 d$.

Times. - 'The Editors have fully fulfilled their expressed intention of making the book a practical guide to sportsmen and naturalists.'

Yorkshire Post.-' Admirably carried out. An efficient second and shortened edition of the Report was greatly needed.'

London: SMITH, ELDER \& CO., 15 Waterloo Place, S.W. 



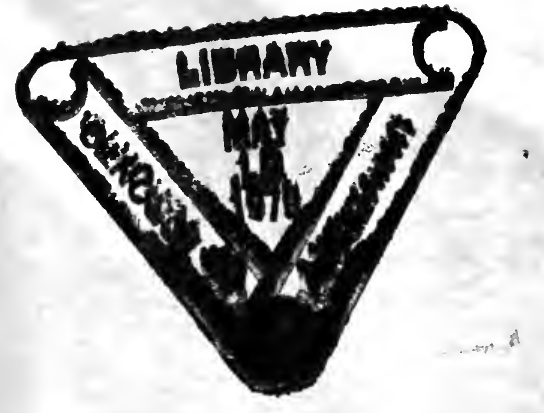




\section{PLEASE DO NOT REMOVE CARDS OR SLIPS FROM THIS POCKET}

In order $t$ inecessa by NO

\section{UNIVERSITY OF TORONTO LIBRARY}

$\mathrm{H} \cdot \mathrm{S} /$

6 Stra

. Thr

Class A

Class B

Full H

Shipley Arthur Everett, (Sir)
"J" 
